\author{
Universidade de São Paulo \\ Instituto de Física
}

\title{
Estudo de interações entre membranas lipídicas e biomoléculas
}

\section{Barbara Bianca Gerbelli}

Orientador(a): Profa. Dra. Elisabeth Andreoli de Oliveira

Tese de doutorado apresentada ao Instituto de Física como requisito parcial para a obtenção do título de Doutora em Ciências.

Banca Examinadora:

Profa. Dra. Elisabeth Andreoli de Oliveira (IFUSP)

Prof. Dr. Leandro Ramos Souza Barbosa (IFUSP)

Profa. Dra. Maria Tereza Lamy (IFUSP)

Profa. Dra. Iolanda Cuccovia (IQUSP)

Prof. Dr. Jean Jacques Bonvent (UFABC)

São Paulo 


\section{FICHA CATALOGRÁFICA}

Preparada pelo Serviço de Biblioteca e Informação do Instituto de Física da Universidade de São Paulo

Gerbelli, Barbara Bianca

Estudo de interações entre membranas lipídicas e biomoléculas. São Paulo, 2018.

Tese (Doutorado) - Universidade de São Paulo. Instituto de Física. Depto. de Física Experimental.

Orientador: Profa. Dra. Elisabeth Andreoli de Oliveira

Área de Concentração: Biofísica

Unitermos: 1. Lipídio; 2. Peptídeo; 3. Biofísica; 4. DNA; 5. SAXS. 
Ao meu amado Pedro... 

A minha família, em especial a minha mãe Roseli... 



\section{AGRADECIMENTOS}

Primeiramente agradeço a Deus por estar ao meu lado em todos os momentos. Me dar forças nos momentos em que pensei em desistir de tudo, resiliência em momentos que achei que tudo iria dar de errado e principalmente paciência na minha vida profissional.

Agradeço ao meu querido Pedro, por ele sim ter muito paciência comigo. Pedro, agradeço por todos estes anos juntos e saiba que esta tese não sairia se não fosse por você me dando apoio e muitos puxões de orelha. Te amo com ...

Agradeço a minha família, primeiramente a minha mãe que foi outra pessoa que teve muita paciência comigo nestes anos de pós-graduação. Não só agora né, mãe, e sim na vida. Como você disse alguns meses atrás "Se meus filhos são teimosos, é que eles tem personalidade!". Isso só foi possível por sua causa, obrigada por lutar por mim a todos os instantes da minha vida. Aos meus irmãos Clara e Junior que trilharam comigo nesta jornada, e olha a minha responsabilidade de exemplo para vocês. Saibam que se eu me dedico sempre mais, é para vocês terem o melhor exemplo acadêmico possível, pois de vida é a nossa mãe. Ao meu pai e a Denise pelos momentos muito agradáveis que tivemos durante este período e que muitas vezes me faziam esquecer do doutorado. A minha nova família os Oselieros, Pedro (in memoriam), Cilene, Camila, Marcos e Gesica, obrigada por me acolher tão bem nesta família, que eu faço questão de falar que é minha também.

À Beth que além de orientadora, é minha querida amiga. Obrigada por mais de 10 anos de convivência, de muita paciência, por muitos momentos cuidar de mim, principalmente no aspecto mental. Saiba que eu aprendi muito com você durante este tempo e espero que nunca percamos o contato.

Agradeço ao Emerson, que mesmo que a pós-graduação não autorizou foi o meu coorientador mesmo assim. Emerson você é muito especial, e saiba que nunca irá se livrar de mim.

Agradeço a dois alunos de IC que passaram mais de 1 ano comigo Flávio Lidio e Nicolas de Carlos, fomos 6 mãos experimentais neste trabalho, se não fossem vocês as amostras estariam girando até hoje.

Agradeço aos meus colegas do grupo de fluidos complexos, e ex alunos do grupo em especial Eraldo e Renata, pelos bons momentos de convivência que passamos juntos.

Agradeço aos colegas da UFABC, Wendel e principalmente a Bruna, pela "doação" de peptídeos e claro que pela amiga que ganhei para a vida. 
Agradeço aos meus colegas da UAM e cursinhos Maximize e Fatec, que me deram a oportunidade do trabalho e pela convivência. E graças a este "trabalhocinio" pude conseguir terminar o meu doutorado.

Aos colegas da vida seja da graduação ou não, Tassiana, Fernando, Joice, Edneuma entre outros, obrigada pelos momentos de distração e conversas de não física, que me permitiram ser uma pessoa sã depois de tanto tempo.

Agradeço a Universidade de São Paulo, aos funcionários da pós graduação que até o último dia desta tese estavam comigo.

Agradeço ao universo por me fazer passar por tudo que tive que passar, pois graças a estes momentos, hoje sou o que sou.

Barbara. 
"Aqui no entanto, nós não olhamos para trás por muito tempo.

Nós continuamos seguindo em frente,

abrindo novas portas e fazendo coisas novas.

Porque somos curiosos...

e a curiosidade, continua nos conduzindo por novos caminhos.

Siga em frente!"

Walt Disney 



\section{RESUMO}

Esta tese apresenta resultados do estudo de interações entre biomoléculas e membranas compostas de lipídio. Duas classes de biomoléculas foram utilizadas, em primeiro lugar fragmentos de DNA que se inserem na camada aquosa entre as membranas, e peptídeos, que se inserem na parte hidrofóbica da membrana. As membranas de lipídio são constituídas basicamente por lecitina de soja, organizada em vesículas ou fases lamelares.

Foram preparados complexos de lipídios e DNA com fragmentos de 150 pares de base, onde variou-se a composição das membranas na fase lamelar, com a adição de um cosurfactante comercial composto de uma mistura de ácidos graxos. Com essa abordagem foi possível alterar as propriedades elásticas da fase lamelar onde os fragmentos de DNA se inserem. Técnicas de espalhamento de raios-X foram aplicadas para a caracterização estrutural de duas composições distintas da fase lamelar hospedeira, revelando uma variedade de polimorfismos, como já havia sido observado para outras composições. Foi demonstrado que a transição entre os diferentes arranjos dos fragmentos de DNA está correlacionada a mudanças nas propriedades elásticas da fase lamelar hospedeira.

No estudo da interação entre peptídeos e membranas, foram utilizadas vesículas e fases lamelares compostas apenas de lecitina. Os peptídeos utilizados foram duas sequências curtas de aminoácidos: L,L-difenilalanina (FF) e a cisteína-difenilalanina (CFF). A propriedade de auto-organização da FF tem sido reconhecida como elemento chave para a formação de fibras amilóides envolvidas em doenças neurodegenerativas como Alzheimer e Parkinson. Experimentos de FTIR demonstraram que os peptídeos se situam na interface da bicamada interagem mais fortemente com os grupos fosfato do lipídio. A incorporação do peptídeo FF promove alterações nas propriedades elásticas das membranas e, no caso das vesículas, observa-se uma transição multilamelar-unilamelar induzida pelo aumento da concentração de peptídeo. Com a presença do peptídeo CFF essa transição ocorre para concentrações baixas, provavelmente devido a ligações de hidrogênio entre o peptídeo e a membrana, alterando assim a entropia local da membrana. Observou-se ainda, com técnicas de dicroísmo circular e espalhamento de raios-X (WAXS) que, mesmo para essas sequências curtas, os peptídeos se agregam formando estruturas cristalinas que contribuem para a alteração das interações entre membranas e desestabilização da estrutura lamelar.

Palavras chaves: Lipídios; Peptídeo; Interação; Transição multi-unilamelar; DNA, SAXS. 
This thesis presents results of the study of interactions between biomolecules and membranes composed of lipid. Two classes of biomolecules were studied, first fragments of DNA inserted into the aqueous layer between membranes and second, peptides that are inserted into the hydrophobic part of the membrane. Lipid membranes are basically constituted by soy lecithin, which is a biocompatible lipid, organized into vesicles or lamellar phases.

Lipid and DNA complexes were prepared with $150 \mathrm{bp}$ DNA fragments, varying the composition of the membranes in the lamellar phase, with the addition of a commercial commercial co-surfactant composed of a mixture of fatty acids. With this approach, it was possible to change the elastic properties of the lamellar phase where the DNA fragments are inserted. X-ray scattering techniques were applied for the structural characterization of two distinct compositions of the host lamellar phase, revealing a variety of polymorphisms, as had already been observed for other compositions. It has been shown that transitions between the different arrangements of the DNA fragments are correlated to changes in the elastic properties of the host lamellar phase.

In the study of the interaction between peptides and membranes, vesicles and lamellar phases composed only of lecithin were used. The peptides used were two short amino acid sequences; L, L-diphenylalanine (FF) and cysteine diphenylalanine (CFF). The self-association property of FF has been recognized as a key element for the formation of amyloid fibers involved in neurodegenerative pathologies such as Alzheimer's and Parkinson's disease. FTIR experiments have shown that the peptides are at the interface of the bilayer and interact more strongly with the phosphate groups of the lipid. The incorporation of FF peptide promotes changes in the elastic properties of the membranes and in the case of the vesicles, a multilamellar-unilamellar transition is observed induced by the increase of the peptide concentration.

With the presence of CFF peptide this transition occurs at low concentration, probably due to hydrogen bonds between peptide and membrane which change the local entropy of the membrane. It is also observed with circular dichroism and X-ray scattering (WAXS) techniques that, even for these short sequences, the peptides aggregate forming crystalline structures that contribute to the modification of membrane interactions and destabilization of the lamellar structure.

Key words: Lipids; Peptide; Interaction; Multi-unilamellar transition; DNA, SAXS. 


\section{LISTA DE FIGURAS}

Figura I-1 Representação pictórica do modelo de mosaico fluido como proposto nos anos 1970 (a) e conforme desenvolvimento mais recente (b). O papel desempenhado por grupos proteicos (em verde) é muito mais relevante do que imaginado anteriormente, tanto do ponto de vista estrutural quanto funcional. Adaptado de (Goñi, 2014).

Figura II-1 Desenho esquemático de uma molécula anfifilica. 22

Figura II-2 Influência da geometria da molécula pela variação do valor parâmetro de empacotamento na estrutura supramolecular. Figura extraída de (Gerbelli, 2012).....

Figura II-3 Estrutura da molécula da lipídio.

Figura II-4 (a) até (g) são apresentados os tipos de organização dos lipídios nas fases lamelares.

Observando que as cadeias carbônicas podem ser mais flexíveis (a) como mais rígidas (b). Em

(h) até (j) são apresentadas as possíveis organizações das cabeças polares.

Figura II-5 Esquema de uma fase lamelar com espessura de bicamada geométrica $\delta$ Mgeo, espessura de camada aquosa $\delta w$ e periodicidade lamelar D. Figura adaptada de (Nagle e Tristram-Nagle, 2000b).

Figura II-6 Desenho esquemático de uma vesícula (a) unilamelar e (b) multilamelar. 28

Figura II-7 Formação de peptídeos a partir de aminoácidos. Em (a) reação de condensação entre o grupo carboxílico e amino de diferentes aminoácidos gerando uma ligação peptídica (representada em azul) (b). Os grupos R1 e R2 correspondem à cadeia lateral de cada tipo de aminoácido. Extraída de (Cox, 2012)......

Figura II-8 Os vinte aminoácidos comumente encontrados em proteínas, ocorrendo sob a forma de L-aminoácidos nos organismos vivos. Extraída de http://www.fcfar.unesp.br/alimentos/bioquimica/imagens/TABELA_AA.GIF..................30

Figura II-9 Figura representando as possíveis estruturas formadas por peptídeos. Em (a) estrutura primária, principalmente formada por ligações peptídicas (b) estruturas secundárias, sendo estas $\alpha$-hélice ou Folha- $\beta$, (c) estruturas terciárias e (d) estrutura quartenária, como por exemplo a hemoglobina. Adaptada do livro (Maxim Ryadnov e Ferenc Hudecz 20017) ...31

Figura II-10: (b) e (d) Fórmulas estruturais dos peptídeos curtos. Em concentrações mais elevadas, tipicamente da ordem de $\sim 1 \mathrm{mgml}$, as sequências exibem propensão à formação de arranjos auto-organizados de morfologia bastante definida. O dímero FF forma estruturas tubulares 
(a), e a sequência contendo cisteína forma nanoesferas (c). Adaptada de (Reches, M e Gazit, E, 2003; Adler-Abramovich et al., 2006).

Figura II-11 (a) Estrutura de hélice da dupla fita de DNA. (b) Representação estrutural dos pares de base e as ligações de ponte de hidrogênio entre os pares de base.

Figura II-12 Vista lateral e superior, respectivamente do DNA. (a) e (b) representando o tipo A e

(c) e (d) representando o tipo B. Figura adaptada de ( $\mathrm{Ng}$ et al., 2000). 34

Figura II-13 Representação esquemática das mesofases observadas para fragmentos de DNA em

(a) fase isotrópica, (b) colestérica, (c) hexagonal e (d) ortorrômbica. 35

Figura II-14: $\mathrm{O}$ espectro de CD para o peptídeo em solução à $28{ }^{\circ} \mathrm{C}$. A linha sólida com uma concentração de 0,83 mgmL e linha pontilhada com 0,515 mgmL. O espectro da linha sólida é característico de uma estrutura tipo randon coil, enquanto o da linha pontilhada apresenta dois mínimos em 208 e 222 nm, característicos da formação da estrutura secundária $\alpha$-hélice. Extraído da referência (Tsapis et al., 2002). .37

Figura II-15 (a) Curvas de espalhamento Iq $\times$ q para duas frações volumétricas de lipídio, $\phi$ lip $=$ 0,38 e 申lip =0,48, respectivamente. Comportamento do parâmetro de Caillé em função da razão de peptídeo lipídio (b) para фlip $=0,38$ e (c) $\phi$ lip $=0,48$. Extraída da referencia (Tsapis et al., 2002) .38

Figura II-16 (a) Curvas de espalhamento Iq $\times$ q variando a razão de peptídeo/lipídio. Comportamento dos parâmetros estruturais em função da razão de peptídeo/lipídio (b) periodicidade lamelar (c) parâmetro de Caillé. Extraída da referência(Pabst et al., 2007)......39

Figura II-17 Resultados experimentais para o complexo de DPPC-A6R (a) Espectros de CD e (b) curvas de SAXS. Extraída da referência (Dehsorkhi et al., 2013).

Figura II-18 Representação de uma estrutura tipo "sanduíche”, L $\alpha$ c, encontrada por Radler et al (Radler et al., 1997). A fase lamelar é constituída por lipídios e as moléculas de DNA estão inseridas nos canais aquosos entre as bicamadas. Extraída de (Radler et al., 1997).....

Figura II-19 Desenho esquemático das fases hexagonais de lipídio tipo colmeia de abelha (a) inversa com os fragmentos de DNA intercalados dentro dos tubos formados pelos lipídios; (b) direta com os fragmentos no interstício da fase lipídica. Extraída de (Koltover et al., 1998; Ewert et al., 2006).

Figura II-20 Curvas de espalhamento de raios X para o sistema multilamelar composto por bicamadas com $70 \%$ de lecitina e $30 \%$ de Simulsol ${ }^{\circledR}$ e para o complexo. Observa-se que a incorporação do DNA promove o aumento da correlação entre as bicamadas, que se manifesta pela aparição de picos de ordem superior. A adição de sal ao complexo $(250 \mathrm{mM}$ de 
acetato de amônia) não produz qualquer tipo de mudança nos parâmetros estruturais. Extraída de (Da Silva et al., 2011). .43

Figura II-21

Figura II-22 Figura esquemática das possíveis organizações dos fragmentos de DNA inseridos na camada aquosa de uma fase lamelar fluida. (a) $L \alpha$ ?, (b) $L \alpha N$ (c) L $\alpha$ RC Cada bastão de DNA é separado lateralmente por distância a e verticalmente por uma periodicidade lamelar d. (d) L $\alpha$ H. O parâmetro a caracteriza a distância entre fragmentos de DNA vizinhos..

Figura II-23 Figura esquemática de um arranjo cristalino, onde D é o espaçamento entre os planos cristalográficos e $\theta$ é o ângulo formado entre o feixe incidente com o plano cristalográfico.

Figura II-24 Feixe de raios X espalhado por uma partícula (kr), fixa no espaço, formando um ângulo $2 \theta$ em relação ao feixe incidente. $O$ vetor de onda qz pode ser descrito pela distância entre os planos cristalinos (Eq II-3)

Figura II-25 Representação esquemática do espalhamento de raios-X para (a) sistemas monocristalinos ou filmes orientados e (b) sistemas policristalinos.

Figura II-26: Representação esquemática da fase lamelar e a intensidade de espalhamento I(q) correspondente: (a) para membranas rígidas; (b) com flutuações da periodicidade lamelar (c) com flutuações de ondulações da membrana. Figura adaptada de (Pabst, 2005) .

Figura II-27: Contraste de densidade eletrônico da bicamada obtida com o modelo de 4 gaussianas (Gerbelli, 2012). .52

Figura II-28 Esquema da técnica de IR com método ATR. A radiação incidente sofre o fenômeno de reflexão total no interior do sistema formado pelo cristal e amostra. .54

Figura II-29 Espectro de IR de um filme de PC em excesso de água. (a) As regiões espectrais destacadas por cores diferentes trazem informação associadas à região hidrofóbica (cinza), interfacial (verde) e sobre grupos polares (azul). (b) Resultados experimentais para o DMPC.

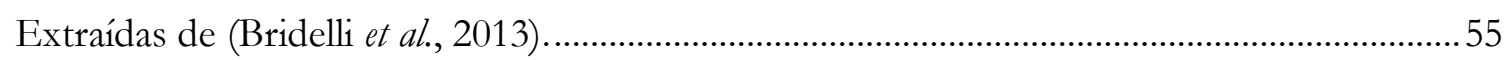

Figura II-30 Esquema da difração de uma partícula. Adaptada de (Li e Barron, 2014).................. 56

Figura II-31 Se as partículas são grandes, as flutuações na intensidade coletada não menores do que se as partículas fossem pequenas. Adaptada de (Li e Barron, 2014). 57

Figura II-32 Comportamento de uma curva de autocorrelação em função do tempo, para partículas com diâmetro grande e pequeno. Para as partículas com diâmetro menor, observa-se que o decaimento exponencial acontece mais rápido do que as partículas com diâmetro maior....58 
Figura III-1 Desenho esquemático do experimento de eletroforese. A tensão utilizada na cuba de eletroforese foi de $100 \mathrm{~V}$ e corrente elétrica foi de $150 \mu \mathrm{A}$.

Figura III-2: Eletroforese de uma solução de DNA submetida a ciclos de 1 hora (30 minutos de sonicação seguidos de 30 minutos de repouso). $\mathrm{Na}$ figura, os números superiores indicam a quantidade de horas total para a solução. As barras horizontais estão sobrepostas as bandas do DNA de referência, com o número de pares de base indicado ao lado da barra.

Figura III-3: Á esquerda: Distribuição de tamanho dos fragmentos de DNA obtidos nos ciclos de sonicação e repouso. Á direita: Evolução do tamanho e polidispersidade dos fragmentos ao longo dos ciclos para soluções com 1 semana de hidratação (superior) e 2 semanas (inferior). As barras representam uma estimativa da largura da distribuição.

Figura III-4: Fórmula estrutural (a) Fórmula estrutural do ácido oleico e (b) palmítico funcionalizados com a cadeia de PEG, onde $<\mathrm{n}>=10$ monômeros e (c) lipídio majoritário da lecitina de soja.

Figura III-5: Fórmulas estruturais dos peptídeos curtos.

.66

Figura III-6: Fonte convencional de raios-X, Xeuss ${ }^{\circledR}$. (a) Equipamento antes de 2015, com somente o detector de SAXS. (b) Câmara de vácuo e detector de WAXS.

Figura III-7 Diagrama de Transformadas de Fourier em espalhamento á baixo ângulos. Correlação a função $p(r)$ e sua transformada de Fourier, a intensidade espalhada I(q), assumindo-se simetria esférica. Figura extraída de (Glatter, 2002). 71

Figura III-8: Perfil de contraste de densidade eletrônico para uma membrana lipídica Extraída de

(Gerbelli, 2012). .72

Figura III-9: Equipamento de FTIR da empresa Varian 660, em modo ATR, localizado no laboratório CEM da UFABC. .73

Figura III-10 Máquina de DLS -Brookhaven 90 Plus. Extraído de https://www.brookhaveninstruments.com/nanobrook-173plus-particle-size-analyzer ....... 74

Figura III-11 Espectro de CD teórico para as estruturas secundárias. Figura extraída de (W. e Freenman, 2006). .74

Figura III-12 Equipamento de Dicroísmo Circular, JASCO 810, localizado no laboratório de Biofísica da Unifesp. 75

Figura III-13 Texturas de microscopia de luz polarizada (a) Cruzes de maltas formadas por agregados de amido Extraído de http://www.sbfgnosia.org.br/Ensino/amido.html (b) textura de fases lamelares onde padrões caóticos de claro e escuro são observados (Silva, 2007). .76 
Figura III-14 Microscópio de luz polarizada e de fluorescência Leica CRT Mic, , localizado no laboratório do grupo de Fluidos complexos da USP..

Figura IV-1 Curvas de espalhamento obtidas para sistemas ternários com sistema lamelar hospedeiro composto por 30\% de lecitina e 70\% de Simulsol ${ }^{\circledR}$. Do lado direito observam-se texturas em microscopia de fluorescência e polarização. A região verde clara indica a presença de fragmentos de DNA. Os algarismos romanos indicam diferentes formas de organização dos fragmentos de DNA na fase lamelar hospedeira (ver discussão no texto).

Figura IV-2 Representações esquemáticas do modelo geométrico de cada célula unitária (da esquerda para a direita: retangular centrada e hexagonal). D é a distância de repetição lamelar, a é a distância entre bastões de DNA dentro de uma mesma camada de água, ФDNA é o diâmetro dos cilindros de DNA e $\delta \mathrm{m}$ é a espessura da bicamada lipídica.

Figura IV-3 Curva Iq $\times$ q para uma amostra com arranjo nemático dos fragmentos de DNA intercalados na fase lamelar ( $\phi$ lip $=0,48)$. As setas verdes indicam os picos que caracterizam a fase lamelar e a seta vermelha indica a presença dos fragmentos de DNA na fase lamelar.

Figura IV-4: Evolução dos parâmetros estruturais que caracterizam as diferentes estruturas observadas para os complexos de lipídio/DNA com duas composições de membrana distintas; (a) 10\% de lecitina e (b) 30\% de lecitina. Onde os símbolos quadrados representam a periodicidade lamelar e a o parâmetro de ordem dos fragmentos de DNA.

Figura IV-5: Evolução dos parâmetros estruturais que caracterizam as diferentes estruturas observadas para os complexos de lipídio/DNA para membranas contendo $70 \%$ de lecitina. Extraída de (De Oliveira et al., 2010; Da Silva et al., 2011).

Figura IV-6: Evolução do parâmetro de Caillé $(\eta)$ e período lamelar (D) das fases lamelares hospedeiras com composições: (a) 30\%, (b) 10\% de Simulsol. Os círculos e os quadrados representam os valores de $\eta$ e $D$, respectivamente.

Figura IV-7 Espessura da bicamada obtida a partir do ajuste do perfil de contraste eletrônico para as mesmas composições.

Figura IV-8: Representação esquemática da organização dos fragmentos de DNA entre as bicamadas, de armadilha descrita no texto.

Figura IV-9: Espectro de FTIR da lecitina no intervalo de número de onda 800 a $1800 \mathrm{~cm}^{-1}$...... 89

Figura IV-10: Espectro de FTIR variando-se a razão P/L no intervalo de número de onda de 800 a $1800 \mathrm{~cm}^{-1}$ para os complexos com o peptídeo (a)FF e (b)CFF. Na parte superior dos gráficos as curvas representam o espectro de absorbância dos respectivos peptídeos puros. .90 
Figura IV-11: Espectro de FTIR variando a razão P/L no intervalo de número de onda 2800 a $3030 \mathrm{~cm}^{-1}$ para os complexos com o peptídeo (a)FF e (b)CFF.

Figura IV-12: Comparação da distribuição de tamanhos versus RH de vesículas compostas de

Lecitina e compostas de lecitina-peptídeo na razão $\mathrm{P} / \mathrm{L}=0,1$.

Figura IV-13: Variação do raio hidrodinâmico médio das vesículas variando a razão molar P/L.

Onde os símbolos quadrados representam os resultados do peptídeo FF e os círculos a CFF.

Figura IV-14 Imagens de microscopia confocal para amostras de $\mathrm{P} / \mathrm{L}=0,2$ para os complexos de peptideo-lipidio.

Figura IV-15: Difratogramas de fases lamelares compostas de lecitina para os dois peptídeos estudados e para duas razões molares.

Figura IV-16: Curvas Iq $\times$ q para fases lamelares compostas de lecitina e peptídeo com diferentes razões molares de peptídeo e lipídeo. (a) FF e (b) CFF. As linhas contínuas em vermelho correspondem ao ajuste utilizando-se o Método da Deconvolução Gaussiana (seção

Figura IV-17: (a) Comportamento da função p(r) para a membranas de lipídios contendo CFF com o detalhe da curva na região de $r<5 \mathrm{~nm}$. (b) Comparação entre as funções $p(r)$ para as membranas contendo diferentes tipos de peptídeos com $\mathrm{P} / \mathrm{L}=0,2$ com o detalhe das curvas evidenciando mudança no contraste eletrônico na parte hidrofóbica..

Figura IV-18 Comportamento dos parâmetros estruturais obtidos a partir do ajuste das curvas de intensidade de espalhamento, com o modelo de 4 gaussianas. (a) Espessura da bicamada. (b) Parâmetro de Caillé. (c) Contraste de densidade eletrônica.

Figura IV-19(a) Gráfico de $\operatorname{lnI} \times$ q2 na região de Guinier. As linhas pontilhadas são apenas um guia para os olhos. (b) Curva de SAXS para o peptídeo FF na razão $\mathrm{P} / \mathrm{L}=0,2$. Na região de maior ângulo, observou-se um pico em torno de $3.2 \mathrm{~nm}^{-1}$ correspondente a estrutura cristalina do peptídeo. Esta região pode ser observada no detalhe da figura (c) Espectros de CD para duas amostras de FF com razões de $\mathrm{P} / \mathrm{L}$ diferentes.

Figura IV-20: (a) Difratograma de uma amostra contendo FF com razão P/L=0,05 e $\phi_{\text {lip }}=0,80$ (b) Curvas de I(q) vs. q de WAXS para fases lamelares compostas de peptídeo-lipídio com diferentes razões de P/L. (c) Difratograma de uma amostra contendo FF, com P/L=0,2 e . (d) Curvas de $\mathrm{I}(\mathrm{q})$ vs. q para a razão molar de $\mathrm{P} / \mathrm{L}=0,2$ variando a fração volumétrica de água.

Figura IV-21 Curvas de difração de raios-X para cristais de FF para duas simetrias diferentes. A curva superior apresenta picos de difração correspondentes à estrutura ortorrômbica e a curva 
inferior uma estrutura hexagonal. Os picos assinalados com asterisco foram observados nos experimentos de WAXS para o sistema FF-lipídio (Figura IV-20 (b) e (d)) . Adaptado de referência (Heredia et al., 2010). 110

Figura IV-22: Curvas de I(q) vs. q de SAXS para fases lamelares compostas de peptídeo-lipídio com diferentes razões molares de peptídeo. Para cada razão molar variou-se a fração volumétrica de água (a) $\mathrm{P} / \mathrm{L}=0,001$ (b) $\mathrm{P} / \mathrm{L}=0,01$ (c) $\mathrm{P} / \mathrm{L}=0,1$ (d) $\mathrm{P} / \mathrm{L}=0,2$. 111

Figura IV-23 Comportamento da periodicidade lamelar em função do inverso da fração volumétrica de lipídio para diferentes razões de P/L e para a lecitina pura. As linhas tracejadas são apenas guia para os olhos.

Figura IV-24 - Comportamento dos parâmetros ajustados (a) espessura eletrônica da bicamada. (b) Inset do comportamento da espessura da bicamada eletrônica para $\mathrm{P} / \mathrm{L}=0,2$ comparada com a lecitina pura (Oliveira et al., 2012). As linhas tracejadas e contínua são apenas guias para os olhos.

Figura IV-25: Comportamento do perfil do contraste de densidade (a) $\mathrm{P} / \mathrm{L}=0,001$ e (b) $\mathrm{P} / \mathrm{L}=0,2$ 115

Figura IV-26 Parâmetro de Caillé em função da fração volumétrica de lipídio. As linhas são apenas guia para os olhos. .116

Figura IV-27 Comportamento da área por cabeça polar em função da periodicidade lamelar(a) para o complexo peptídeo-lipídio com diferentes razões de P/L e (b) lecitina pura. Extraída de (Bougis, 2016).

Figura IV-28 Comportamento da espessura geométrica em função da área por molécula (a) para o complexo peptídeo-lipídio com diferentes razões de P/L e (b) lecitina pura (Bougis, 2016).

Figura IV-29 Texturas em microscopia de luz polarizada, para duas frações volumétricas de lipídeo para diferentes $\mathrm{P} / \mathrm{L}$

Figura IV-30 Curvas de SAXS para duas frações volumétricas de lipídio (a) P/L=0,05 e (b) $\mathrm{P} / \mathrm{L}=0,2$. 121

Figura V-1 Comportamento da periodicidade lamelar em função do inverso da fração volumétrica de lipídio para diferentes razões de $\mathrm{P} / \mathrm{L}$ e para a lecitina pura. 124

Figura V-2: Comportamento dos parâmetros estruturais para o peptídeo CFF. (a) Comportamento do parâmetro de Caillé. (b) Espessura da bicamada. Onde as linhas são apenas guia para os olhos. 


\section{LISTA DE TABELA}

Tabela II-1 Transições de fase em solução aquosa de DNA $(50 \mathrm{~nm})$ em solução tampão de acetato de amônia a 0,25 M. O domínio de cada estrutura observada é delimitado pela concentração de DNA no solvente ou pela sua fração volumétrica. A distância de separação entre os fragmentos (a) bem como a distância da dupla hélice (Shélice) são apresentadas abaixo. Extraída da referência (Livolant e Leforestier, 1996)........................................................................ 35

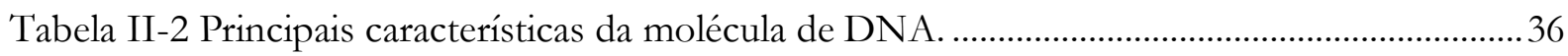

Tabela II-3: Principais grupos funcionais de uma molécula de DMPC (Bridelli et al., 2013).........55

Tabela IV-1 Indexação dos picos qhk para as diferentes estruturas observadas para o arranjo de

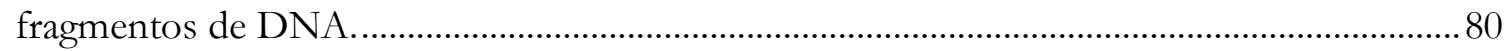

Tabela IV-2 Resumo das principais vibrações na região dos grupos fosfato e colina. Os valores do

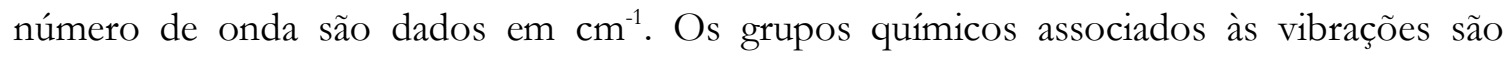
mostrados na coluna da esquerda............................................................................................ 92 


\section{GLOSSÁRIO}

ATR: Reflexão total atenuada, metodologia utilizada na coleta dos dados de FTIR.

Bicamada: Dupla camada formada por moléculas lipídicaanfifílicass em solução aquosa.

C: Aminoácido císteina

CD: Dicroísmo circular (Espectroscopia na região UV).

CFF: Trípepídeo (Císteina-difenilalanima)

DLPC: Dilinoleoilfosfatifidilcolina

DLS: Espalhamento de Luz dinâmico.

DMPC: Dimiristoilfosfatidilcolina

DOTAP: Dioleoil-trimetilamónio-propano

DPPC: Dipalmitoilfosfatidilcolina

Estrutura ortorrômbica: Caracteriza-se pela organização de três eixos cristalográficos mutuamente perpendiculares ( $\mathrm{a}, \mathrm{b}$ e $\mathrm{c}$ ).

Estrutura primária: Constituida de uma sequência linear de aminoácidos, predominantemente formada de ligações peptídicas.

Estrutura quaternária: Promovida pela junção de pelo menos duas estruturas terciárias.

Estrutura secundária: A estrutura secundária é gerada pela interação dos átomos que constituem as estruturas primárias, formando então ligações intermoleculares. As conformações secundárias mais estudadas são a $\alpha$-hélice e a estrutura $\beta$-folha.

Estrutura terciária: Promovida pela junção de estruturas secundárias e primárias. Neste tipo de estrutura, regiões polares e apolares dos aminoácidos são relevantes para a conformação final. As principais estruturas terciárias de são as globulares e as fibrosas.

F: Aminoácido fenilalanima

Fases hexagonais: Na mesofase colunar hexagonal (2D) o centro de massa dos agregados dedas moléculas apresenta um ordenamento posicional hexagonal bidimensional, conservando a mobilidade ao longo do seu eixo de simetria.

Fases isotrópicas: Não apresentam nenhum tipo de orientação, nem de posiciposiçãoonal ou orientacionaçãol

Fases lamelares: Arranjo de bicamadas periodicamente espaçadas com ordenamento posicional ao longo de uma direção (nas outras duas direções as moléculas anfifílicas podem apresentar diferentes arranjos).

Fases nemáticas: Mesofase líquido cristalina mais simples, caracterizada pela ordem orientacional de longo alcance, e ordem posicional apenas de curto alcance. A mesofase nemática só pode ser formada por moléculas anisotrópicaslongada de forma, taiss como cilindros e achatadas como discos.

Fator de estrutura $\boldsymbol{S}(\boldsymbol{q})$ : No caso de fases lamelares, descreve a repetição da estrutura da bicamada lipídica. 
Fator de forma $\boldsymbol{P}(\boldsymbol{q})$ : No caso de fases lamelares, descreve a forma e características da bicamada lipídica.

FF: Dipeptídeo composto de duas fenilalanima (Di-fenilalanima)

FTIR: Espectroscopia de Infravermelho por Transformada de Fourier.

Hidrofílica: Região que tem afinidade com moléculas polares tais como a água.

Hidrofóbica: Região que não tem afinidade com moléculas polares tais como a água.

$\boldsymbol{I}(\boldsymbol{q})$ : Intensidade de luz espalhada.

$\boldsymbol{I}_{\mathbf{0}}$ : Padrão secundário de espalhamento usado por ser um padrão cujo espalhamento não depende do ângulo de espalhamento na faixa angular de interesse.

$I_{\text {amostra }}$ : Espalhamento da amostra.

I $_{\text {back }}$ : Espalhamento do capilar que contém a amostra. Uutilizado no experimento de espalhamento de raios-X ("background").

$I_{\text {ruído }}$ e $\boldsymbol{I}_{\text {sombra }}$ : Espalhamentos que correspondem a corrente de fundo do equipamento e a sombra do feixe direto incidente no "beamstopper".

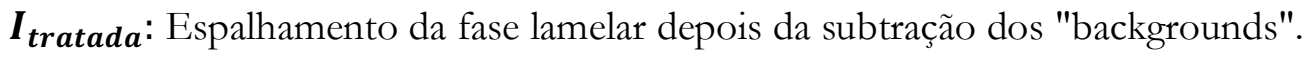

K: Módulo de curvatura do "bulk" [J/m]

Lipídio zwiteriônico: Classe de lipídio cuja região hidrofilica, embora possua carga elétrica total nula e, apresenta um momento de dipolo elétrico.

LUV: Vesículas unilamelares grandes.

$\boldsymbol{L}_{\boldsymbol{\alpha}}^{?}$ : Fase lamelar fluida sem a presença identificação clara dade organização dos fragmentos de DNA

$\boldsymbol{L}_{\boldsymbol{\alpha}}^{\boldsymbol{H}}$ : Fase lamelar fluida com organização hexagonal dos fragmentos de DNA.

$\boldsymbol{L}_{\boldsymbol{\alpha}}^{N}$ : Fase lamelar fluida com organização nemática dos fragmentos de DNA.

$\boldsymbol{L}_{\boldsymbol{\alpha}}^{\boldsymbol{R} \boldsymbol{C}}$ : Fase lamelar fluida com organização retangular centrada dos fragmentos de DNA.

$\boldsymbol{L}_{\boldsymbol{\alpha}}$ : Fase lamelar que ocorre à temperatura mais alta, e alta hidratação. Nessa fase, as moléculas apresentam uma ordem líquida, com as cadeias carbônicas sem qualquer tipo de ordenamento.

$\boldsymbol{L}_{\boldsymbol{\beta}}^{\prime}$ e $\boldsymbol{P}_{\boldsymbol{\beta}}^{\prime}$ : Fases que as caudas carbônicas estão estendidas e podem apresentar organização bidimensional de curto alcance, o que confere maior rigidez à bicamada.

Moléculas anfifílicas: moléculas que apresentam duas regiões com diferentes solubilidades, uma hidrofilica e hidrofóbica.

Oligopeptídeo: Peptídeos que contém até 50 resíduos de aminoácidos

$\boldsymbol{p}(\boldsymbol{r})$ : função distribuição de pares de tamanho

P/L: razão de peptídeo e lipídio utilizado na preparação das amostras.

pb: Pares de bases nitrogenadas que compõe a sequencia de DNA, neste trabalho utilizou-se 150pb Peptídeos: Compostos orgânicos formados por ligações peptídicas, com pelo menos dois resíduos de aminoácidos.

Periodicidade lamelar (D): Definida como: $\boldsymbol{\delta}_{\boldsymbol{m}}^{\boldsymbol{g e o}}+\boldsymbol{\delta}_{\boldsymbol{w}}$, representa o padrão de repetição formado pela bicamada + camada aquosa. 
Polipeptídeo: Peptídeos compostos de 50 até 10000 resíduos de aminoácidos

POPC: Palmitoil-Oleilfosfatidilcolina

q: Módulo do vetor de espalhamento no espaço recíproco.

SAXS: Espalhamento de raios-X a baixo ângulo.

v: volume molar

WAXS: Espalhamento de raios-X a alto ângulo.

$\boldsymbol{\alpha}$-hélice: Estrutura polipeptídica que pela ação de pontes ligações de hidrogênio, formam uma espiral ou uma hélice.

$\boldsymbol{\beta}$-folha: Estrutura polipeptídica que pela ação de ligaçõespontes de hidrogênio, formam um zigue-zague, promovendo a formação de estruturas planares.

$\boldsymbol{\Delta} \boldsymbol{\rho}:$ perfil do contraste de densidade eletrônico

$\boldsymbol{\eta}$ : Parâmetro de Caillé, que reflete está relacionado a amplitude das flutuações das membranas.

$\lambda$ : Comprimento de onda.

$\boldsymbol{\Sigma}$ : Área por molécula de surfactante na interface membranabicamada-solvente.

$\boldsymbol{R}_{\boldsymbol{h}}$ : Raio de giro hidrodinâmico, obtido pela técnica de DLS.

$\boldsymbol{r}_{\text {máx }}$ : raio máximo da partícula obtido pela análise da $\mathrm{p}(\mathrm{r})$.

$\boldsymbol{\delta}_{\boldsymbol{m}}^{\boldsymbol{e l e}}$ : Espessura eletrônica da bicamada eletrônica, determinada a partir do ajuste dos dados experimentais utilizando o modelo de 4 gaussianas.

$\boldsymbol{\delta}_{\boldsymbol{m}}^{\boldsymbol{g e o}}$ : Espessura geométrica da bicamada geométrica, determinada a partir do modelo geométrico.

$\boldsymbol{\delta}_{\boldsymbol{w}}$ : Distância de separação entre as bicamadas, ou espessura da camada aquosa.

$\boldsymbol{v}^{\mathbf{- 1}}$ : Número de onda, sendo este o inverso do comprimento de onda.

$\boldsymbol{\phi}_{\text {lip }}$ : Fração volumétrica de lipídio.

$\boldsymbol{\phi}_{\boldsymbol{w}}$ : Fração volumétrica de água.

$\overline{\boldsymbol{B}}$ : Módulo de compressibilidade $[\mathrm{Pa}]$ 


\section{ÍNDICE}

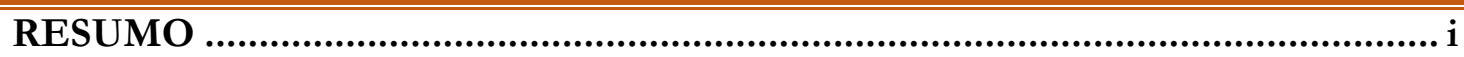

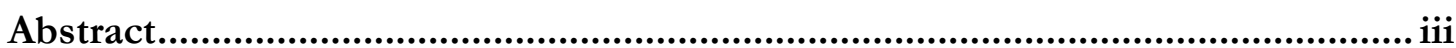

LISTA DE FIGURAS

LISTA DE TABELA ...................................................................................... vii

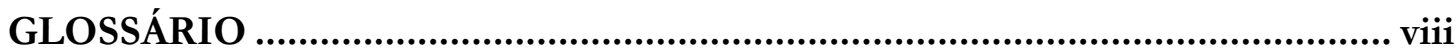

Índice xii

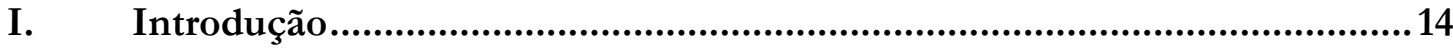

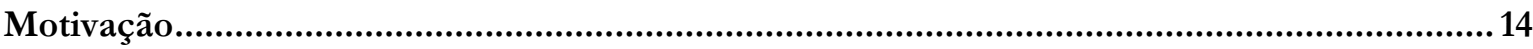

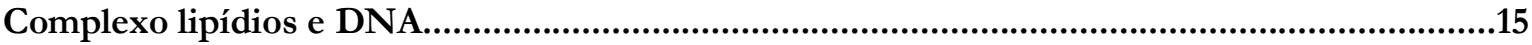

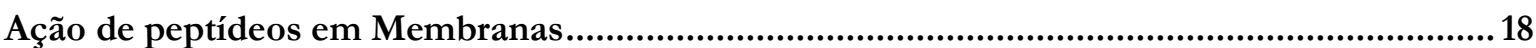

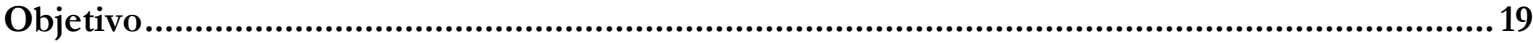

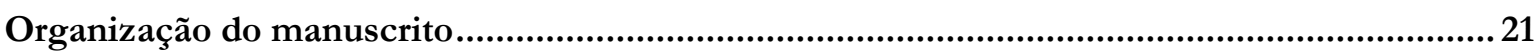

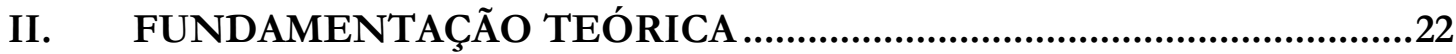

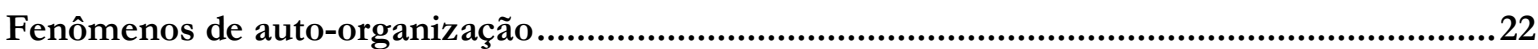

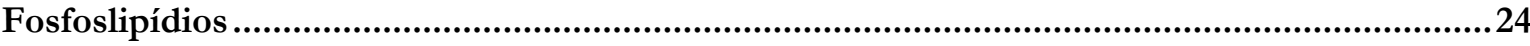

Fases lamelares

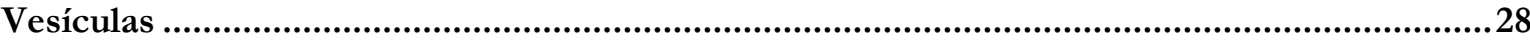

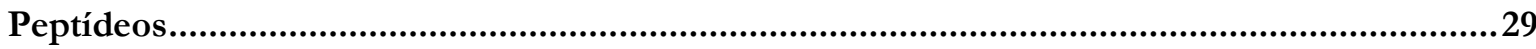

DNA

Ação de peptídeos em membranas lipídicas ..................................................................................

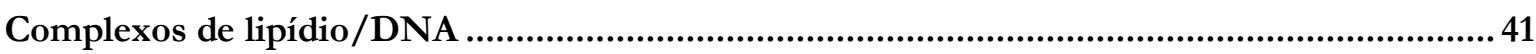

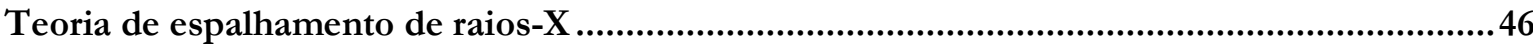

Contextualização da teoria de espalhamento de raios-X em fases lamelares ...............................................4 48

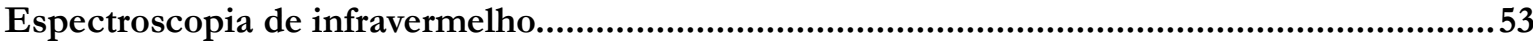

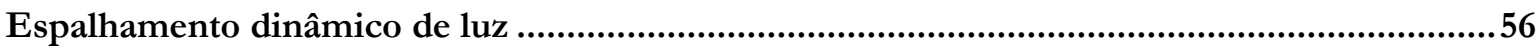

III. MATERIAIS E MÉTODOS DE PREPARAÇÃO ...................................60

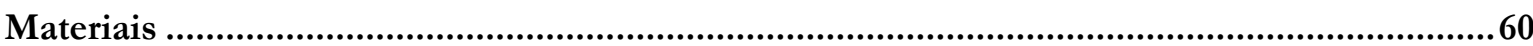

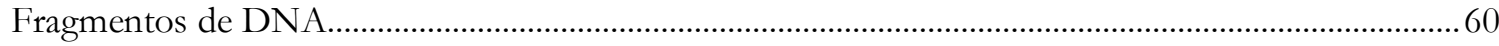

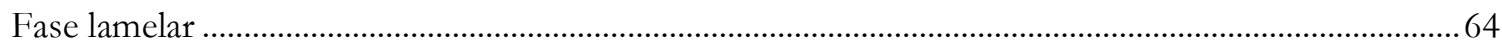

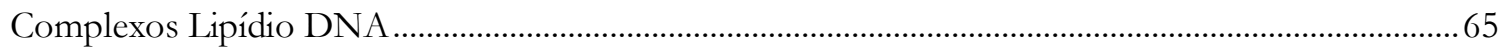

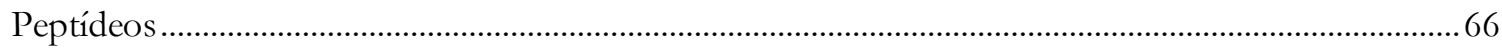

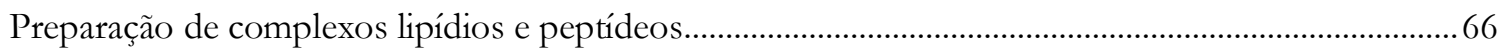

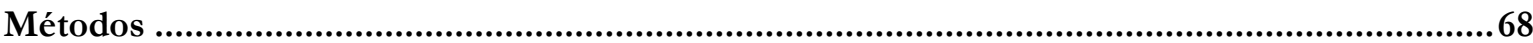

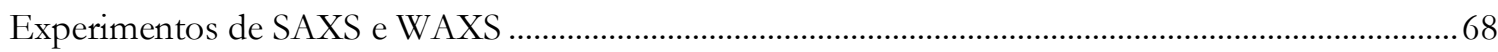

Métodos de tratamento e ajustes das curvas experimentais........................................................................ 70

Espectroscopia de infravermelho com Transformada de Fourier (FTIR) …………………………...... 72

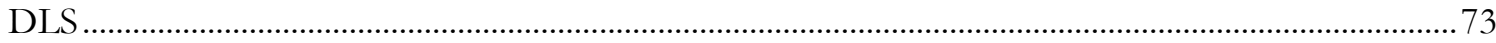

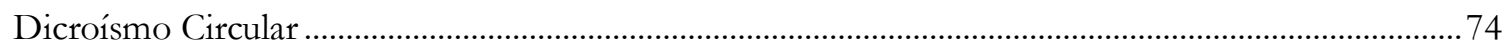

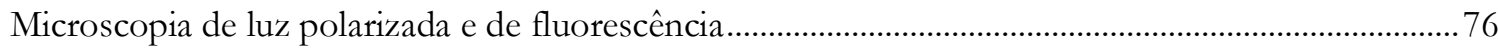

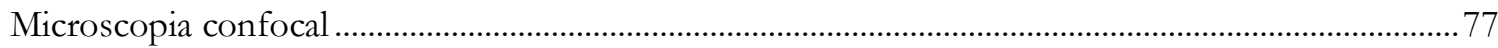




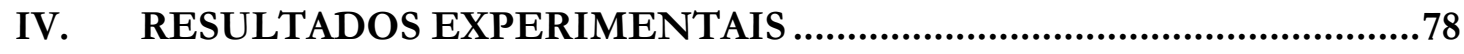

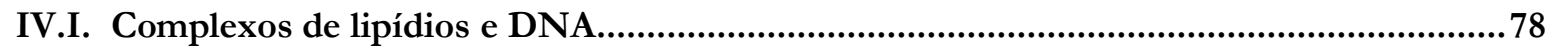

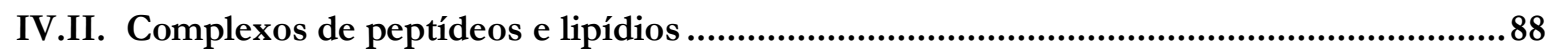

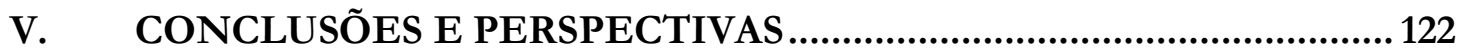

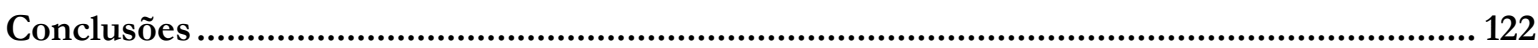

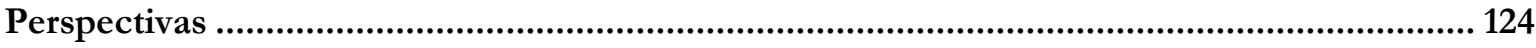

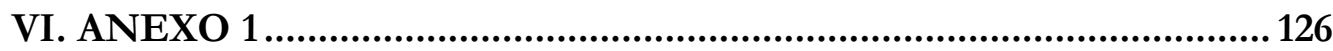

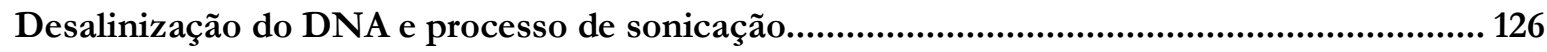

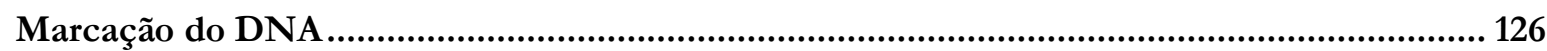

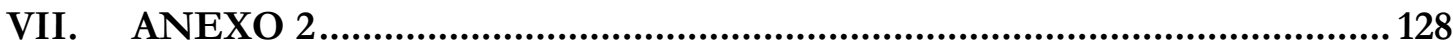

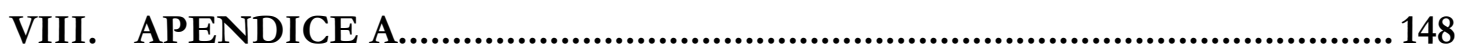

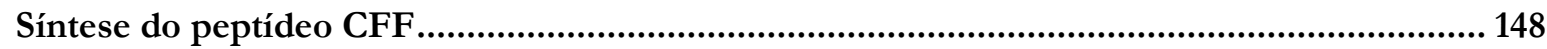

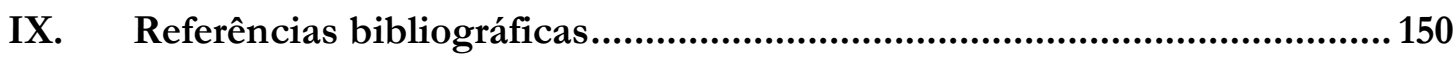




\section{INTRODUÇÃO}

\section{Motivação}

Membranas celulares são sistemas complexos formados majoritariamente por fosfolipídios que se organizam em bicamada, consistindo em uma barreira semipermeável que delimita o meio externo e o citoplasma. Além desta função de fronteira para a maquinaria intracelular, elas também atuam como substrato para uma variedade de biomoléculas incluindo glicoproteínas, glicolipídios, proteínas e sequências curtas de aminoácidos (Singer, S. e Nicolson, G., 1972; Capito et al., 2008; Goni, 2014).

Essas biomoléculas podem ocupar ambas as interfaces da membrana ou podem ser hospedadas no interstício hidrofóbico da fase lipídica, onde desempenham papel fundamental na comunicação e regulação de vários processos biológicos (Standley et al., 2010). A descrição acurada desses sistemas não é tarefa simples e diversos modelos têm sido propostos ao longo das últimas quatro décadas com vistas a ampliar nossa compreensão acerca de membranas biológicas (Nicolson, 2014). Entre esses modelos, um dos mais antigos e bem-sucedidos é o chamado modelo do mosaico fluido (Singer, S. J. e Nicolson, G. L., 1972), segundo o qual espécies lipídicas organizadas em bicamadas servem de suporte para os grupos proteicos. Ainda de acordo com esta proposição, as biomoléculas estão em movimento contínuo com lipídios e proteínas "fluindo" ao longo da estrutura membranar.
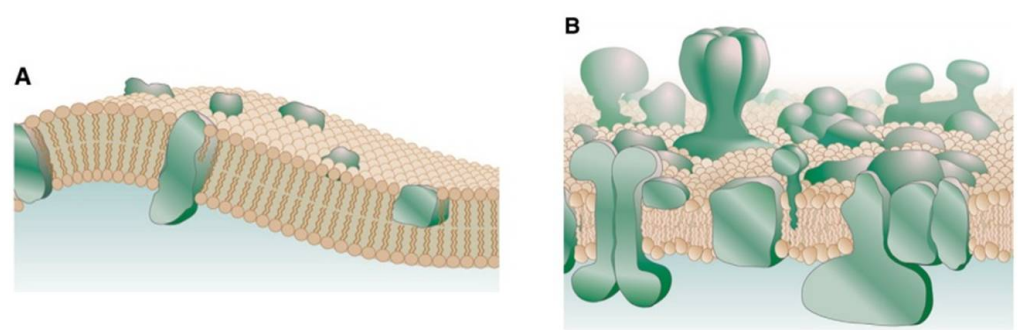

Figura 0-1 Representação pictórica do modelo de mosaico fluido como proposto nos anos 1970 (a) e conforme desenvolvimento mais recente (b). O papel desempenhado por grupos proteicos (em verde) é muito mais relevante do que imaginado anteriormente, tanto do ponto de vista estrutural quanto funcional. Adaptado de (Goñi, 2014). 
A grande maioria dos desenvolvimentos posteriores são aperfeiçoamentos desta representação pioneira e, mais recentemente, o papel exercido por domínios proteicos intercalados tem sido intensamente revisitado (Murray et al., 2010; Catala, 2012; Goñi, 2014; Nicolson, 2014). Particularmente, tem sido observado que a presença de proteínas em membranas biológicas é muito maior do que imaginado inicialmente e, mais que isso, esses grupos introduzem modificações estruturais locais na matriz lipídica se relacionando de maneira íntima com as funções desempenhadas por diferentes domínios da membrana (Nicolson, 2014). As propriedades estruturais e elásticas da bicamada lipídica são moduladas pela presença dessas biomoléculas e, portanto, o estudo das interações mútuas é uma questão relevante.

Vários estudos fundamentais para a compreensão de processos biológicos envolvendo membranas têm sido conduzidos in vitro ou em sistemas que mimetizam a membrana celular, tais como fases lamelares, ou vesículas lipídicas. Embora sejam sistemas mais simples, eles permitem o controle de diversos parâmetros que possibilitam a exploração da interação entre as bicamadas com uma variedade de peptídeos (Pabst et al., 2007; Domingues et al., 2013; Moshe et al., 2013). Uma abordagem frequente para investigar a ação de peptídeos em membranas celulares, é utilizar estes sistemas lipídicos simplificados associados com pequenas sequências de aminoácidos.

\section{Complexos de Lipídios e DNA}

Sistemas multilamelares formados por bicamadas lipídicas regularmente separadas entre si por canais aquosos têm sido bastante utilizados para estudos fundamentais visando a compreensão de alguns processos biológicos (Capito et al., 2008; Murray et al., 2010; Standley et al., 2010; Catala, 2012; Nicolson, 2014) ou aplicações em biotecnologia (Siddhanta e Shields, 1998; Luo e Saltzman, 2000; Langer e Tirrell, 2004; Sackmann, 2006; Wang et al., 2007). A incorporação de partículas coloidais ou biomoléculas na camada aquosa (Radler et al., 1997; Siddhanta e Shields, 1998; Luo e Saltzman, 2000; Langer e Tirrell, 2004; Yamamoto e Tanaka, 2005; Angelatos et al., 2006; Sackmann, 2006; Wang et al., 2007; Kahn et al., 2009; De Oliveira et al., 2010) abre um vasto campo de aplicações para a ciência de materiais e biomédicas. A compreensão dos processos de autoorganização das partículas em geometrias impondo confinamento "suave" (Dan, 1997; Smith et al., 1997; Odriozola et al., 2006; Koynova e Tenchov, 2009; Nygard et al., 2009) surge, então, como um grande desafio para o avanço nessa área.

Nesse contexto, a preparação de lipoplexos a partir da incorporação de DNA a uma fase lamelar hospedeira tem atraído interesse nos últimos anos, tendo em vista particularmente 
aplicações em terapia gênica (Radler et al., 1997; Luo e Saltzman, 2000; Langer e Tirrell, 2004; Angelatos et al., 2006; Koynova e Tenchov, 2009). Como o DNA é uma biomolécula altamente aniônica, uma estratégia bastante adotada para a formulação do complexo consiste em incorporar lipídios catiônicos à membrana, servindo-se das interações eletrostáticas (Radler et al., 1997; Yamamoto e Tanaka, 2005; Odriozola et al., 2006). Embora a preparação de lipoplexos a partir de lipídios neutros tenha sido demonstrada (Kim et al., 2009), existem poucos trabalhos neste sentido na literatura. Isso está associado à dificuldade para a formação do complexo, a qual é provavelmente governada por um mecanismo entrópico relacionado às flutuações térmicas dos fragmentos de DNA e das bicamadas (Gelb e Gubbins, 2000). Porém, essa proposta não descreve de maneira satisfatória a variedade de estruturas que tem sido observada (Colin e Roux, 2002; Pott e Roux, 2002; Pott et al., 2003), especialmente no regime extremamente concentrado, em que os fragmentos de DNA encontram-se confinados entre as bicamadas e as flutuações térmicas são inibidas.

Nos últimos anos, o grupo de Fluidos Complexos do Instituto de Física da USP (GFCx) tem estudado propriedades estruturais e dinâmicas de complexos formados por fragmentos curtos de DNA e membranas lipídicas. Neste caso, os segmentos de DNA possuem 150 pares de bases $(\mathrm{pb})$, e podem ser considerados como bastões rígidos, os quais são intercalados nos canais aquosos da fase multilamelar. A fase hospedeira é composta por membranas majoritariamente constituídas por lecitina de soja e um co-surfactante comercial baseado numa mistura de ácidos graxos, o Simulsol ${ }^{\circledR}$ (Gerbelli et al., 2013).

A presença do cosurfactante permite modular as propriedades elásticas das bicamadas e contribuem para o aumento da flexibilidade da estrutura lamelar. Essas mudanças são acompanhadas da reorganização das moléculas no plano da bicamada, afetando parâmetros estruturais tais como espessura da bicamada e área por cabeça polar. As interações entre as bicamadas também são afetadas, uma vez que o aumento da flexibilidade da membrana resulta em aumento da amplitude das flutuações térmicas e da interação repulsiva devido aos efeitos estéricos. Além disso, como o cosurfactante apresenta uma parte hidrofílica constituída por uma cadeia de polietileno glicol (PEG), o aumento da concentração do surfactante implica em mudanças na interface e mudanças na conformação das cadeias do polímero, que também afetam as propriedades elásticas da membrana (Gerbelli et al., 2013).

Por um lado, a mudança na hidratação da fase lamelar permite controlar o confinamento vertical imposto aos fragmentos de DNA intercalados entre as bicamadas, e por outro lado, a variação da composição da membrana, com a incorporação do cosurfactante permite alterar significativamente as propriedades elásticas da membrana com reorganização molecular no plano 
da bicamada, ou seja, a modulação do confinamento lateral (Gerbelli, 2012; Rubim, 2016). Na prática, os efeitos do confinamento lateral e vertical estão acoplados pois mudanças na hidratação da bicamada também resultam em reorganização das moléculas anfifilicas no plano da bicamada (Rubim, 2010).

Nos trabalhos anteriores, ao estudar estes lipoplexos, os autores exploraram a mudança do confinamento vertical promovido pela mudança da hidratação da fase hospedeira. Para uma dada composição de membrana, foram identificadas formas distintas de organização dos fragmentos de DNA (Silva, 2010); um ordenamento chamado de nemático em que os fragmentos apresentam ordem orientacinal no interior da camada aquosa e um ordenamento hexagonal 2D, para o qual a ordem orientacional e posicional correlacionada inter-camadas. Assim, parece natural investigar os mecanismos físicos que governam a organização dos fragmentos de DNA, que se inserem na fase aquosa entre as membranas de lipídio. 


\section{Ação de peptídeos em Membranas}

Na literatura há diversos estudos dedicados à investigação das interações entre peptídeos antimicrobianos (AMPs) e membranas biológicas miméticas compostas de misturas lipídicas baseadas em uma classe chamada de fosfatidilcolinas (Schmidtchen et al., 2011; Malanovic et al., 2015; Pott et al., 2015; Wang et al., 2015; Moniruzzaman et al., 2017). Os mecanismos exatos pelos quais esses compostos são capazes de desestabilizar bicamadas lipídicas não são ainda muito bem compreendidos, embora saiba-se que os efeitos globais dependem das propriedades físico-químicas dos lipídios e peptídeos tais como a presença ou não de carga elétrica no sistema.

Nesse contexto, alguns trabalhos na literatura mostraram que pequenas quantidades de AMPs podem induzir mudanças locais de curvatura da membrana induzidas por interações eletrostáticas diretas entre os grupos carregados disponíveis nas cadeias laterais dos aminoácidos e nas cabeças polares lipídicas (Hristova et al.; Pan et al., 2009; Dehsorkhi et al., 2013; Domingues et al., 2013; Su et al., 2013). No entanto, quando se aumenta a concentração de peptídeos, isto pode gerar a permeação da membrana com a formação de poros, afetando o ordenamento lipídico local e, com isto, a estabilidade da membrana (Domingues et al., 2013; Moshe et al., 2013; Delin et al., 2016; Fu et al., 2017). Hristova et al (Hristova et al.) propõem que a auto-organização de peptídeos induzida por interações de natureza eletrostática, bem como a formação de ligações de hidrogênio ou mesmo a presença de interações $\pi$-stack (Fu et al., 2017), geram estruturas complexas e estas desempenham papel crucial para a lise da membrana (Hristova et al.). Um aspecto recorrente desses achados é o fato de que existe forte correlação entre o tipo de aminoácido presente no segmento peptídico e a capacidade de ruptura das membranas, o que tem sido interpretado como consequência direta da natureza das interações intermoleculares envolvidas (Dehsorkhi et al., 2013; Castelletto et al., 2014).

Um dos grandes atrativos de se estudar, nos últimos anos, a agregação e auto-organização de peptídeos deve-se à sua implicação em patologias neurodegenerativas e também pela sua potencial aplicação no desenvolvimento de estruturas ordenadas em escala nanométrica (Rajagopal e Schneider, 2004; Teles e Fonseca, 2008) . A presença de resíduos aromáticos nessas sequências tem sido considerada um fator chave para promover o crescimento direcional através de interações

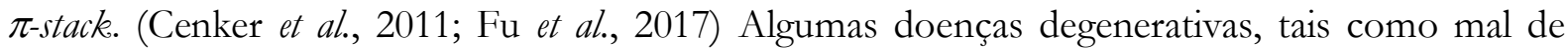
Parkinson e Alzheimer estão associadas ao desenovelamento de proteínas que se agregam e formam fibras, chamadas de fibras amiloides (Hamley, 2012). Embora a formação dessas fibras envolva proteínas relativamente longas, a presença de determinadas sequências curtas é 
fundamental para que isso ocorra (Hamley, 2007; Hamley e Castelletto, 2007). Um grupo que apresenta particular propensão para a formação de fibras amiloides é o dímero L-difenilalanina (FF), presente no segmento central do peptídeo precursor do Alzheimer (Dobson et al., 2003; Chiti e Dobson, 2006). Vários trabalhos na literatura demonstram a habilidade de sequencias curtas contendo a di-fenilalanina em se auto-organizar com uma variedade de polimorfismos incluindo estruturas tubulares, nanofios e vesículas esféricas (Reches, M. e Garit, E., 2003) (Reches e Gazit, 2006) (Yan et al., 2010).

\section{Objetivo}

O objetivo geral deste trabalho é o estudo de interações entre membranas de lipídios e biomoléculas. Foram utilizadas duas classes de biomoléculas, fragmentos de DNA e peptídeos. Os fragmentos de DNA, por serem hidrofílicos permanecem na fase aquosa e se intercalam entre as bicamadas, enquanto os peptídeos, por serem hidrofóbicos, se incorporam á membrana, o que permite explorar diferentes aspectos das interações mútuas.

A primeira etapa do trabalho concentrou-se no estudo de complexos de lipídios e DNA utilizando como sistema modelo a fase lamelar composta de lipídios neutros e fragmentos de DNA de 150 pares de base. O objetivo específico foi o investigar o papel de mecanismos entrópicos na estabilização das diferentes estruturas supramoleculares. Uma ferramenta que se apresenta nessa investigação é modulação das interações entre as bicamadas por meio da variação da composição da membrana.

A maior contribuição deste estudo está em explorar a região onde a matriz lamelar hospedeira é composta majoritariamente de ácidos graxos etoxilados. A incorporação do cosurfactante á membrana permite explorar o efeito do aumento da interação repulsiva de longo alcance devido as flutuações térmicas e também introduzir alterações na interface devido a presença das cadeias hidrofilicas de PEG. Foram utilizadas duas composições de membrana, contendo 70\% e 90\% em massa de cosurfactante, e para cada composição foi explorada a linha de diluição. A caracterização estrutural do complexo se deu por meio de técnicas de microscopia de luz polarizada e espalhamento de raios-X a baixo ângulo (SAXS)

Além disso, pretendeu-se estudar a influência de fragmentos mais longos (segmentos flexíveis com cerca de 1000 pb) a esta matriz lipídica. Por motivos descritos com maior detalhe na seção Materiais e Métodos, avanços na obtenção de fragmentos mais longos propostos neste projeto não foram alcançados devido a problemas de ordem técnica. 
A segunda etapa do trabalho teve por objetivo específico investigar as interações entre peptídeos e membranas de lipídios, utilizando como sistema modelo vesículas e fases lamelares, constituídas apenas de lecitina de soja cuja composição majoritária é dilinoil-fosfatidilcolina, e dois oligopeptídeos: FF, L,L-difenilalanina (FFF) e L-cisteína-L,L-difenilalanina (CFF). A escolha do peptídeo CFF foi inspirada pela presença extensiva deste composto em AMPs e também pelo fato de que as ligações dissulfeto, que acontecem na CFF, desempenham papel fundamental na ruptura da membrana (Mitta et al., 1999; Silva et al., 2000). Além disso, a natureza polar de cadeias laterais de CFF fornece características anfifilicas para este peptídeo e permite usa-lo como sonda de interações na interface da membrana.

O uso destas sequências peptídicas curtas fornece duas principais vantagens para investigar interações de peptídeos/membranas lipídicas: por um lado, elas limitam o número de espécies químicas interagentes nas interfaces de membrana, simplificando a interpretação dos resultados experimentais. Por outro lado, a ausência de carga líquida em ambas as sequências peptídicas e nas membranas de lecitina abre uma janela experimental para examinar o papel de outras interações, além das eletrostáticas diretas predominantes em sistemas AMPs (Delin et al., 2016).

Com a escolha do sistema de estudo, optou-se por duas abordagens de investigação. $\mathrm{Na}$ primeira estudou-se complexos peptídeos/lipídio em excesso de água, situação esta que promove a formação de vesículas lipídicas e permite explorar diretamente a interação da membrana lipídica com o peptídeo, já que o papel do confinamento gerado por uma fase lamelar não é relevante neste regime de interação. $\mathrm{Na}$ segunda abordagem, estudou-se o papel dos peptídeos em membranas organizadas em fases lamelares variando-se o confinamento, por meio da hidratação. Neste regime concentrado pode-se estudar as interações lipídio-lipídio e peptídeo-peptídeo e como elas afetam as interações mútuas.

Para o estudo das fases lamelares, foram preparadas amostras com diferentes concentrações de peptídeos, e para cada composição foi variada a hidratação ao longo da linha de diluição. A técnica de SAXS foi utilizada para determinação de parâmetros estruturais tais como espessura da bicamada, parâmetro de Caillé, contraste de densidade eletrônica, entre outros. Essas amostras foram submetidas a observações em microscopia de luz polarizada para identificação da textura e eventual formação de estruturas micrométricas dos peptídeos.

Nas duas etapas do trabalho há um aspecto comum, que é o efeito de interface. Essas mudanças podem ser induzidas pela incorporação de cosurfactantes, pois as cadeias de PEG comportam-se como pelos na superfície da membrana e ainda, podem adotar conformação 
enoveladas ou estendidas, dependendo da concentração. No caso dos peptídeos, alguns grupos podem estar mais expostos a interface enquanto outros ficam mais imersos na região hidrofóbica, o que afeta a curvatura local.

\section{Organização do manuscrito}

No Capítulo 2 serão apresentadas as principais informações sobre os sistemas estudados, bem como um resumo dos principais trabalhos da literatura. Nesse capítulo também serão apresentados os métodos utilizados para análise dos resultados experimentais de SAXS e FTIR. Os protocolos utilizados para a preparação das amostras bem como detalhes sobre a instrumentação das técnicas experimentais serão descritos no Capítulo 3. O Capítulo 4 apresenta os resultados obtidos para a caracterização estrutural, num primeiro momento, para os complexos lipídio-DNA e, num segundo momento, para os complexos lipídio-peptídeo. O Capítulo 5 traz uma discussão dos principais resultados obtidos neste trabalho e as principais contribuições para a compreensão dos sistemas estudados. 


\section{FUNDAMENTAÇÃO TEÓRICA}

\section{Fenômenos de auto-organização}

Fenômenos de auto-organização, tais como formação de membranas e micelas, estão ligados principalmente a dois fatores; o caráter anfifílico das moléculas que compõem essas estruturas e o efeito hidrofóbico (Tanford, 1980). No primeiro caso, as moléculas apresentam uma região bidrofilica (que possui afinidade com a água e solventes polares), geralmente chamada de “cabeça polar", e uma região hidrofóbica (que não possui afinidade com a água e solventes polares), geralmente chamada de "cauda apolar" (Figura 0-2). No segundo caso, o efeito hidrofóbico implica na tendência da água em minimizar seu contato com compostos hidrofóbicos (Tanford, 1980).

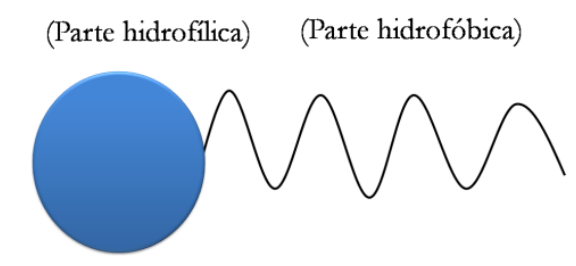

Figura 0-2 Desenho esquemático de uma molécula anfifilica.

Em solução aquosa e em concentrações relativamente pequenas há a tendência, devido ao efeito hidrofóbico dessas moléculas se encontrarem majoritariamente na interface água-ar, diminuindo assim a tensão superficial da solução. É por isso que essas moléculas são também chamadas de surfactantes ou tensoativos. A medida em que se aumenta a concentração do surfactante, há a tendência de formação de agregados no interior da própria solução, os quais podem ser micelas, vesículas, etc. A concentração mínima para formação desses agregados é chamada concentração micelar crítica (CMC) (Israelachvili, 1977) ou, para o caso de peptídeos e proteínas, concentração crítica de agregação (CAC) (Cox, 2012).

Um dos principais fatores que influenciam na forma e tamanho dos agregados é a geometria da molécula anfifílica, a qual pode ser expressa pelo chamado parâmetro de empacotamento $\mathrm{p}=\mathrm{v} / \mathrm{a}_{0} l_{c}$, onde $\mathrm{v}$ é o volume ocupado por um monômero, $\mathrm{a}_{0}$ é a área ocupada pela cabeça polar e $l_{c} \mathrm{o}$ comprimento da cauda (Israelachvili, 1977; Cox, 2012). Os valores apresentados na Figura 0-3 não são precisamente definidos mas sim um indicativo da estrutura supramolecular mais provável para cada tipo de molécula (Israelachvili, 1977). 


\begin{tabular}{|c|l|c|}
\hline $\begin{array}{c}\text { Parâmetro de } \\
\text { empacotamento }\end{array}$ & $\begin{array}{c}\text { Geometria da molécula } \\
\text { anfifilica }\end{array}$ & Estruturas \\
\hline$p<\frac{1}{3}$ & Cone & \\
$\frac{1}{3}<p<\frac{1}{2}$ & Cone truncado & \\
\hline$\frac{1}{2}<p<1$ & Cone truncado & \\
\hline$p>1$ & Cone truncado & \\
\hline
\end{tabular}

Figura 0-3 Influência da geometria da molécula pela variação do valor parâmetro de empacotamento na estrutura supramolecular. Figura extraída de (Gerbelli, 2012) 


\section{Fosfoslipídios}

A palavra "lipídio" vem do grego lipos, que significa "gordura". As moléculas lipídicas fazem parte de uma classe abrangente de materiais biológicos. Os lipídios são compostos de ácidos graxos e são solúveis em água. Alguns lipídios, chamados de fosfolipídios e compostos por um grupo glicerol e um grupo fosfato, são muito utilizados em estudos fundamentais uma vez que compõem cerca $80 \%$ da membrana celular. Fosfolipídios podem ainda estar ligados a outro grupo chamado de colina, formando assim as fosfatidilcolinas (PC) ou lecitinas. A estrutura geral de uma molécula de fosfatidilcolina está representada na Figura 0-4. Tratam-se de moléculas anfifílicas, cuja cauda apolar pode apresentar de 4 a 36 carbonos, além de insaturações que influenciarão na flexibilidade da membrana (Israelachvili, 1977; Cox, 2012). Diferentemente de lipídios carregados, as fosfatidilcolinas são moléculas zwiteriônicas, isto é, possuem carga elétrica resultante nula, porém o arranjo molecular dos átomos presentes no grupo colina e fostato dá origem a um momento de dipolo local (Jones, 2002; Cox, 2012).

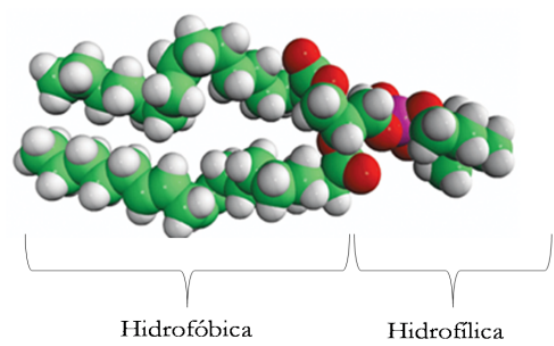

Figura 0-4 Estrutura da molécula da lipídio. 


\section{Fases lamelares}

Lipídios na presença de água podem apresentar uma mesofase chamada de fase lamelar, que é caracterizada por apresentar bicamadas espaçadas em uma única direção, como exemplificado na Figura 0-5, onde essa repetição se dá ao longo do eixo ₹. Diferentes tipos de fases lamelares foram observadas e classificadas segundo o ordenamento das cadeias carbônicas no interior da bicamada, denominadas; $L_{\alpha}, L_{\beta}$, e $P_{\beta}$. As transições de fase se dão por variação de temperatura ou hidratação (Luzzati e Tardieu, 1974).

A fase lamelar fluida, chamada de $L_{\alpha}$, (Figura 0-5 (a)) ocorre para temperaturas mais altas e no domínio de alta hidratação e é caracterizada pelo ordenamento fluido das cadeias hidrocarbônicas (all-cis). Diminuindo-se a temperatura ou hidratação da membrana, pode ocorrer uma transição para a fase lamelar chamada $L_{\beta}$, (Figura 0-5 (b)), onde as cadeias carbônicas apresentam-se na forma estendida (all-trans), inclinadas em relação ao plano da bicamada e com ordem posicional de curto alcance (hexático), conferindo maior rigidez à membrana. Nessa fase há uma mudança considerável no valor do coeficiente de difusão lateral dos lipídios e a transição é acompanhada da mudança do calor latente. Entre as duas fases, pode ainda existir uma fase lamelar chamada de "ripple", ou $P_{\beta^{\prime}}$ (Katsaras et al., 2000a; b) (Figura 0-5 (c)), onde as membranas apresentam uma mistura das características das duas fases descritas anteriormente. Nela, verificase a existência de correlação posicional e translacional e rugosidades periódicas com comprimento de onda da ordem de dezenas de nanômetros, sendo que as cadeias hidrocarbônicas também apresentam orientação e ordem posicional de curto alcance no plano da bicamada (Smith et al., 1987; Karmakar e Raghunathan, 2005). 
(a)

(b)

(c)

(d)

(e)

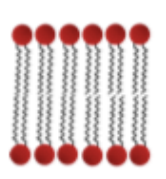

(f)
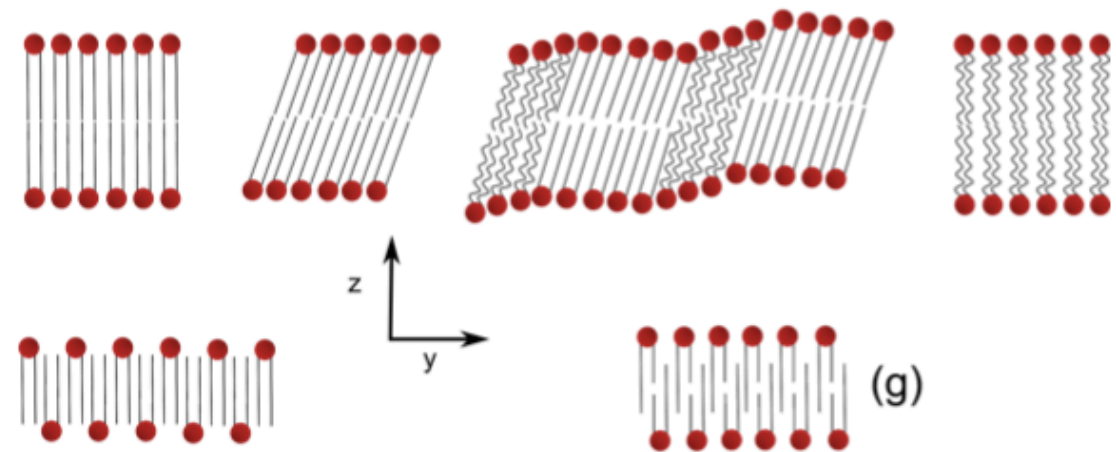

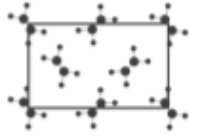

(h)

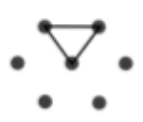

(i)

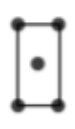

(j)

Figura 0-5 (a) até (g) são apresentados os tipos de organização dos lipídios nas fases lamelares. Observando que as cadeias carbônicas podem ser mais flexíveis (a) como mais rígidas (b). Em (h) até (j) são apresentadas as possíveis organizações das cabeças polares.

Este trabalho trata apenas $\mathrm{da}$ fase lamelar $\mathrm{L}_{\alpha}$, caracterizada pela ordem posicional unidimensional, com periodicidade $(D)$, que corresponde à soma da espessura geométrica $\delta_{m}^{g e o}$ e a espessura da camada aquosa $\left(\delta_{w}\right)$ (Figura $\left.0-6\right)$. Considerando que a espessura da bicamada não é alterada com a hidratação, é possível, com um modelo geométrico simples, obter-se uma relação entre a fração volumétrica de lipídio $\left(\phi_{\text {lip }}\right)$ na solução aquosa e a periodicidade lamelar:

$$
D=\frac{\delta_{m}^{g e o}}{\phi_{l i p}}
$$

que é chamada de lei de diluição usual, e é usada para determinação da espessura da bicamada geométrica (nesse caso, também denominada espessura de Luzzati da bicamada (Nagle e TristramNagle, 2000a; b). 


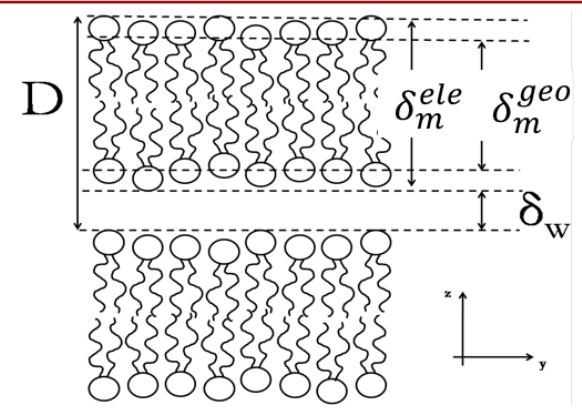

Figura 0-6 Esquema de uma fase lamelar com espessura de bicamada geométrica $\delta_{M}^{g e o}$, espessura de camada aquosa $\delta_{w}$ e periodicidade lamelar $D$. Figura adaptada de (Nagle e Tristram-Nagle, 2000b).

Experimentalmente, observa-se que alguns sistemas lamelares que apresentam uma periodicidade lamelar máxima $\left(D_{\max }\right)$ e um limite de hidratação. Nessa situação há um equilíbrio das interações repulsivas e atrativas entre as membranas e a fase lamelar coexiste com água em excesso (Jendrasiak et al., 1997; Oliveira et al., 2012; Gerbelli et al., 2013; Rubim et al., 2016). 


\section{Vesículas}

Em certas circunstâncias observa-se que bicamadas compostas por lipídios apresentam curvatura que favorecem a formação de vesículas, também chamadas lipossomas, as quais podem ser classificadas de acordo com seu tamanho, que varia de 0,0025 $\mu \mathrm{m}$ até $2,5 \mu \mathrm{m}$ e/ou de acordo com o número de bicamadas. Nesse caso, elas podem ser unilamelares, caso apresentem apenas uma bicamada, ou multilamelares, no caso contrário (Figura II-6). Para as vesículas unilamelares, existe apenas uma bicamada com o interior e o exterior em contato com a solução aquosa. Já as vesículas multilamelares são formadas de diversas bicamadas concêntricas espaçadas de uma camada aquosa. As vesículas unilamelares podem ser classificadas como vesículas unilamelares grandes (LUV), com tamanhos superiores a $0,1 \mu \mathrm{m}$, e vesículas unilamelares pequenas (SUV) com dimensões inferiores a 0,1 $\mu \mathrm{m}$ (Sharma e Sharma, 1997; Akbarzadeh et al., 2013) .
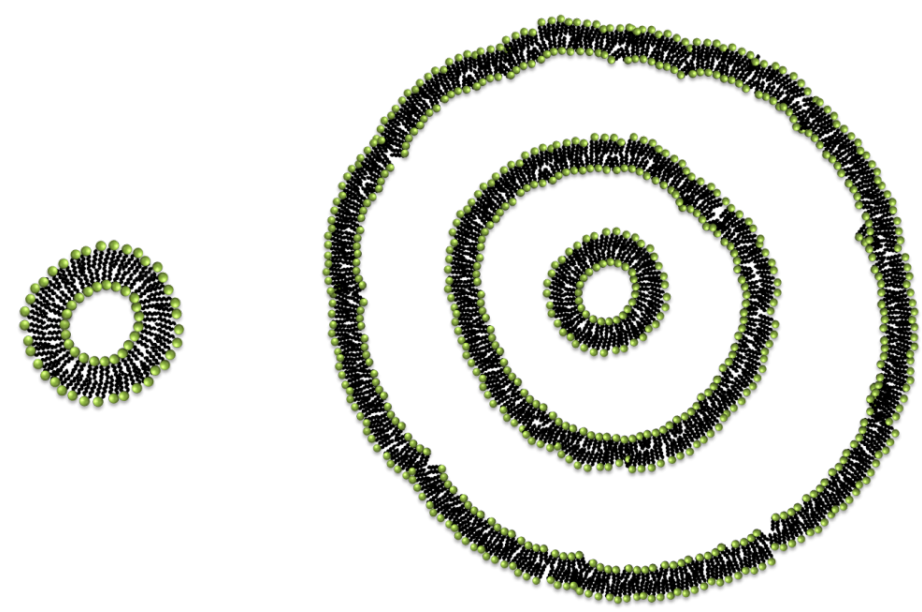

Figura 0-7 Desenho esquemático de uma vesícula (a) unilamelar e (b) multilamelar. 


\section{Peptídeos}

Os peptídeos são biomoléculas formadas por uma sequência específica de aminoácidos, unidos por uma ligação covalente denominada ligação peptídica, que ocorre entre os grupos carboxila e amina dos aminoácidos participantes da reação química (Figura 0-8 A). Na literatura são definidos dois tipos de peptídeos, os oligopeptídeos, formados com até 20 resíduos de aminoácidos (Welker e Von Dohren, 2006), os polipeptídeos, que podem ter até 10000 resíduos de aminoácidos (Cox, 2012).

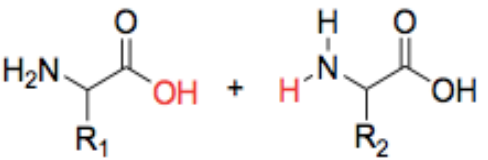

(a)

Aminoácido (1)

Aminoácido (2)<smiles>C[C@H]1C[C@@H](O)C[C@H]1O</smiles><smiles>[R]C(N)C(=O)NC([R2])C(=O)O</smiles>

(b)

\section{Dipeptídeo}

Figura 0-8 Formação de peptídeos a partir de aminoácidos. Em (a) reação de condensação entre o grupo carboxílico e amino de diferentes aminoácidos gerando uma ligação peptídica (representada em azul) (b). Os grupos $R_{1}$ e $R_{2}$ correspondem à cadeia lateral de cada tipo de aminoácido. Extraída de (Cox, 2012). 


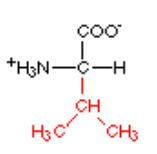

Valina

(val)

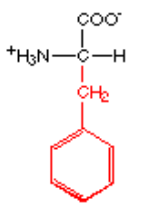

Fenilalanina (Fen)<smiles>[NH3+]C(CS)C(=O)[O-]</smiles>

\section{Cist eína}

(Cis)

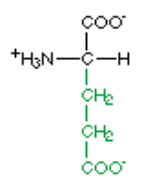

Ácido glutâmico (Glu)

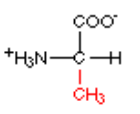

Alanina

(Ala)

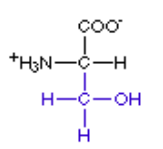

Serina

(Ser)

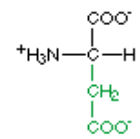

Ácido aspártico (Asp)

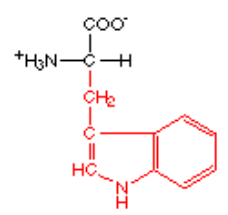

Triptofano (Trp)

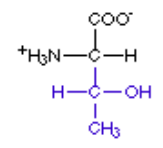

Treonina

(Tre)

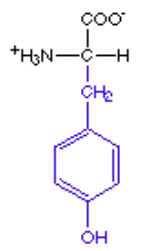

Tirosina

(Tir)

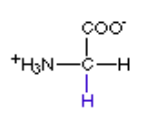

Glicina

(Gli)

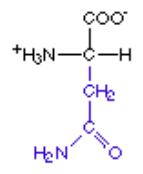

Asparagina

(Asn)

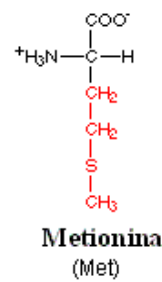

(Met)

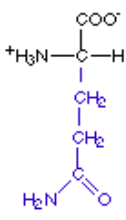

Glutamina

(GIn)
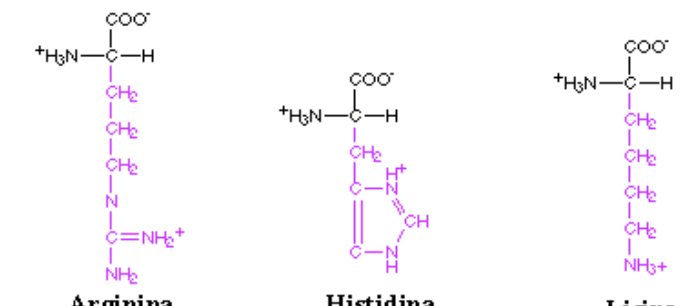

Histidina

(His)

Lisina

(Lis)

Figura 0-9 Os vinte aminoácidos comumente encontrados em proteínas, ocorrendo sob a forma de Laminoácidos nos organismos vivos. Extraída de http://www.fcfar.unesp.br/alimentos/bioquimica/imagens/TABELA_AA.GIF.

Na natureza existem 20 tipos essenciais de aminoácidos distintos, que podem ser catiônicos, aniônicos, hidrofilicos e hidrofóbicos, o que gera uma grande variedade de combinações e características na formação do peptídeo (Figura 0-9). Em uma sequência de aminoácidos pode-se descrever as estruturas em: primária, secundária, terciária ou quaternária.

A estrutura primária consiste na sequência de aminoácidos que compõem o peptídeo (Figura 0-10 (a)). Já a estrutura secundária é formada pelo enovelamento da estrutura primária via ligações de hidrogênio e podem ser principalmente dois tipos: Folha- $\beta$, arranjo ordenado planar no qual os átomos de oxigênio do grupo carboxila interagem com os átomos de hidrogênio do grupo amida, e $\alpha$-hélice, estrutura helicoidal na qual os átomos de hidrogênio ligados aos átomos 
de oxigênio interagem com os outros átomos de hidrogênios no segmento seguinte da hélice (Figura 0-10 (b)). As estruturas terciárias por sua vez apresentam um enovelamento tridimensional que inclui tanto as estruturas primárias quanto secundárias (Figura 0-10 (c)). Por fim, a estrutura quaternária corresponde à junção de duas ou mais estruturas terciárias (Figura 0-10 (d)).

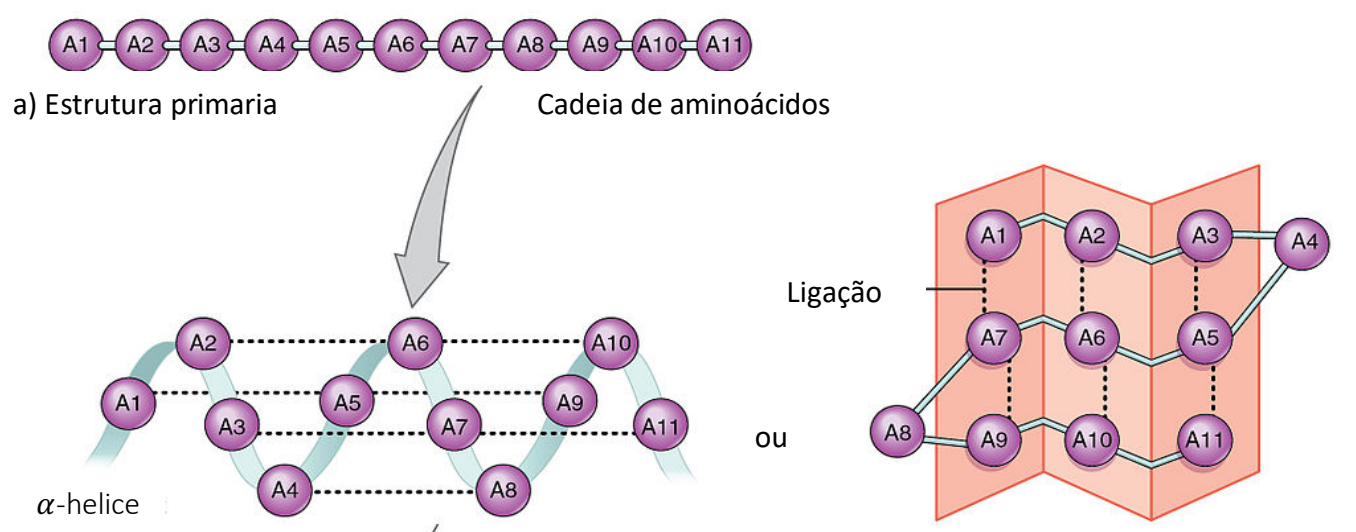

b) Estrutura secundária.
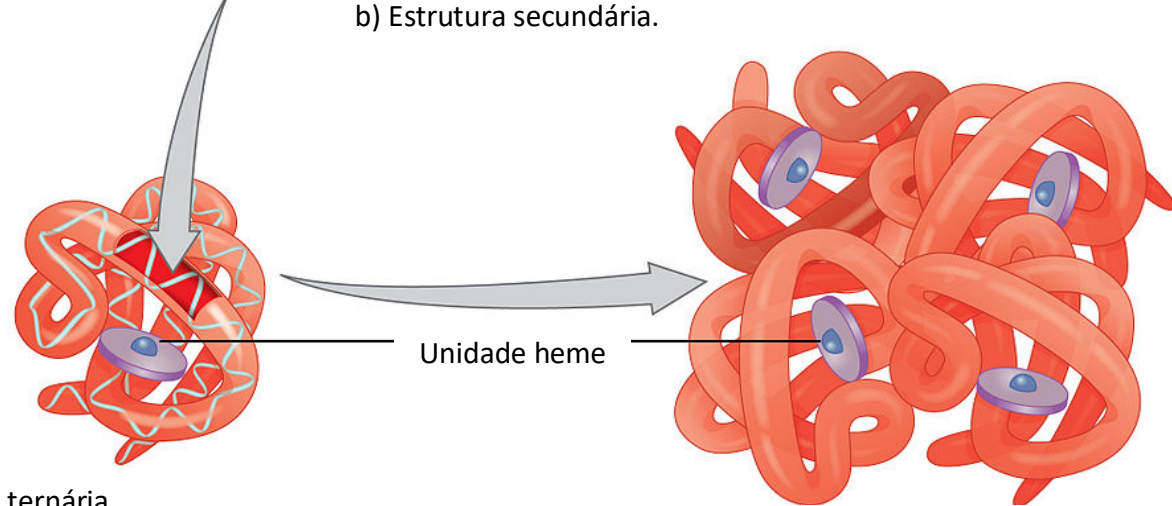

c) Estrutura ternária.

d) Estrutura quaternária.

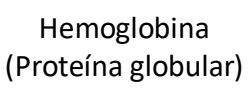

Figura 0-10 Figura representando as possíveis estruturas formadas por peptídeos. Em (a) estrutura primária, principalmente formada por ligações peptídicas (b) estruturas secundárias, sendo estas $\alpha$-hélice ou Folha$\beta$, (c) estruturas terciárias e (d) estrutura quartenária, como por exemplo a hemoglobina. Adaptada do livro (Maxim Ryadnov e Ferenc Hudecz 20017) .

Como mencionado na seção Introdução, neste estudo foram escolhidos oligopeptídeos FF e CFF, que são formados pelos aminoácidos fenilalanina e cisteína. Em solução aquosa, cada um deles forma uma estrutura distinta. FF apresenta alta propensão à formação de estruturas cilíndricas, organizando-se majoritariamente em nanofios que se associam e dão origem a arranjos tubulares em escala microscópica (Adler-Abramovich et al., 2006) . Já a sequência CFF tende a se organizar formando esferas nanométricas (Reches, M. e Gazit, E., 2003) (Figura 0-11). 

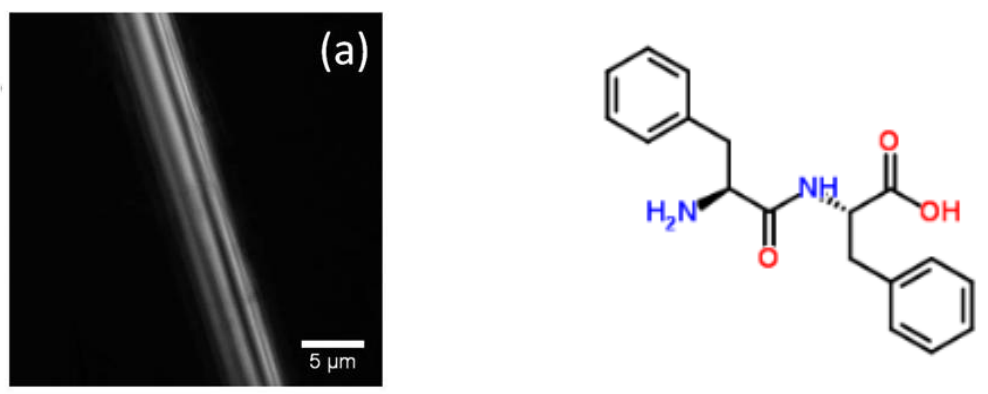

(b)
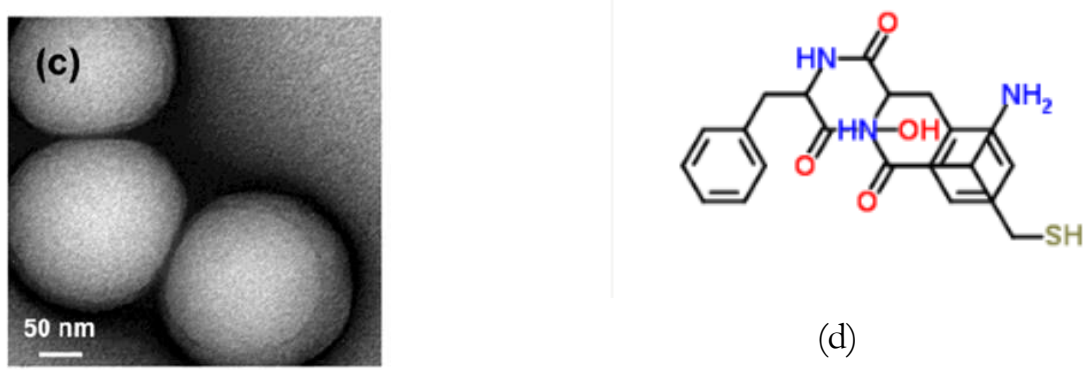

(d)

Figura 0-11: (b) e (d) Fórmulas estruturais dos peptídeos curtos. Em concentrações mais elevadas, tipicamente da ordem de $\sim \mathbf{1} \frac{\boldsymbol{m} \boldsymbol{g}}{\boldsymbol{m} \boldsymbol{l}}$, as sequências exibem propensão à formação de arranjos auto-organizados de morfologia bastante definida. O dímero FF forma estruturas tubulares (a), e a sequência contendo cisteína forma nanoesferas (c). Adaptada de (Reches, M e Gazit, E, 2003; Adler-Abramovich et al., 2006). 


\section{DNA}

O ácido desoxirribonucleico (DNA) é uma biomolécula flexível composta por nucleotídeos, que são formados por um grupo fosfato, uma desoxirribose (um açúcar e uma pentose) e uma base nitrogenada (que pode ser formada por adenina ou guanina e suas complementares timina e citosina, respectivamente) (Cox, 2012) .

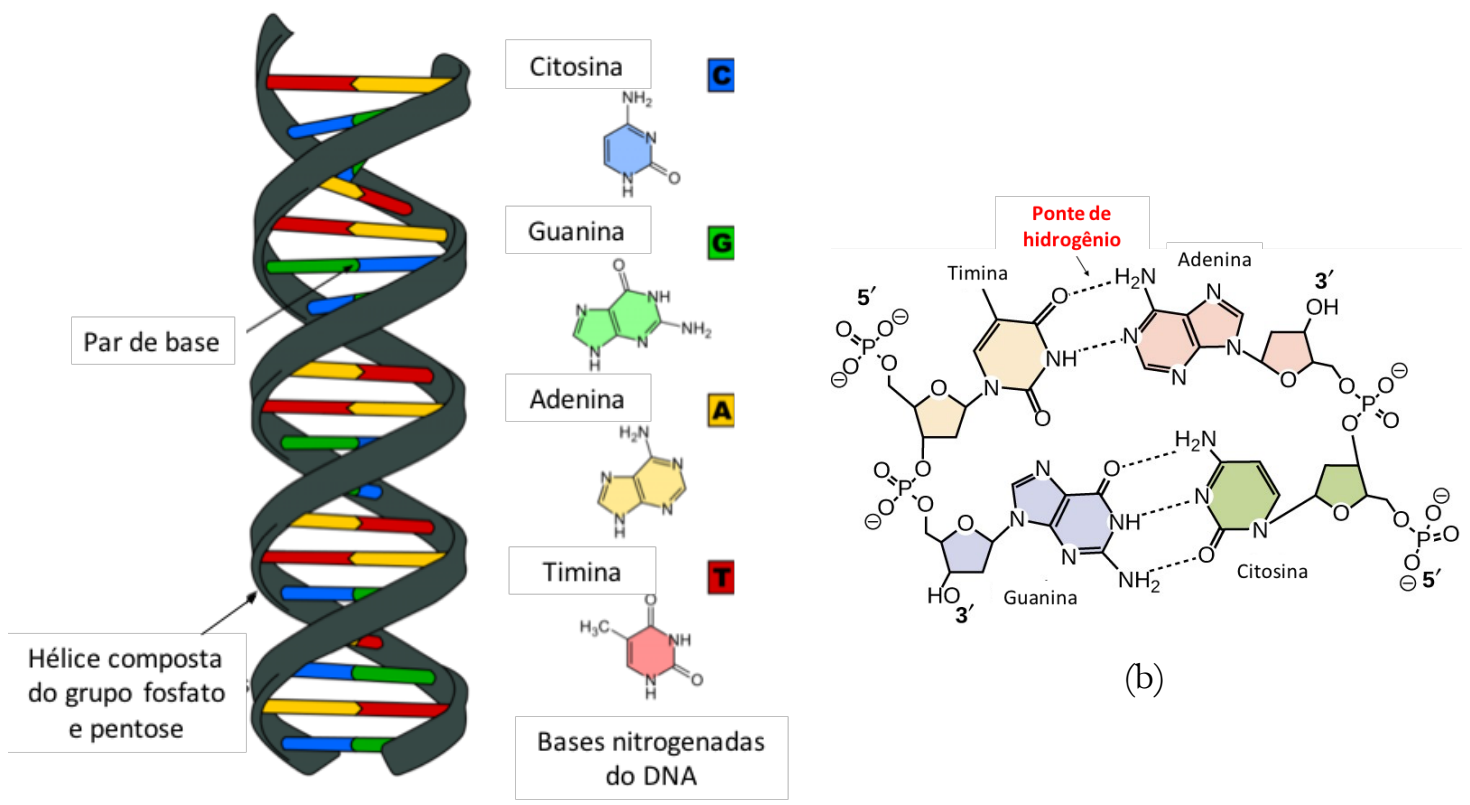

(a)

Figura 0-12 (a) Estrutura de hélice da dupla fita de DNA. (b) Representação estrutural dos pares de base e as ligações de ponte de hidrogênio entre os pares de base.

A estrutura do DNA foi determinada em 1953 (Watson e Crick, 1953) pela técnica de difração de raios-X revelando a dupla hélice antiparalela. De acordo com este modelo, os grupos fosfatos e a pentose formam a estrutura dorsal da cadeia, com as bases nitrogenadas ao centro interagindo via ligações de hidrogênio. Cada par de base resulta em uma carga líquida de dois elétrons.

O comprimento de persistência da cadeia de DNA (isto é, o comprimento em que a molécula apresenta o maior grau de rigidez) é de $\cong 50 \mathrm{~nm}$ ou, equivalentemente, $\cong 150 p b$ (P. G. De Gennes 1995) . As regiões da molécula de DNA compostas pelas pentoses e fosfato apresentam um caráter hidrofilico, já as bases nitrogenadas apresentam um comportamento hidrofóbico. 
A hélice do DNA pode apresentar dois tipos de conformação (Figura 0-13) dependendo das condições do meio tais como pH, hidratação e força iônica. Em solução aquosa, a conformação B é a predominante ( $\mathrm{Ng}$ et al., 2000).

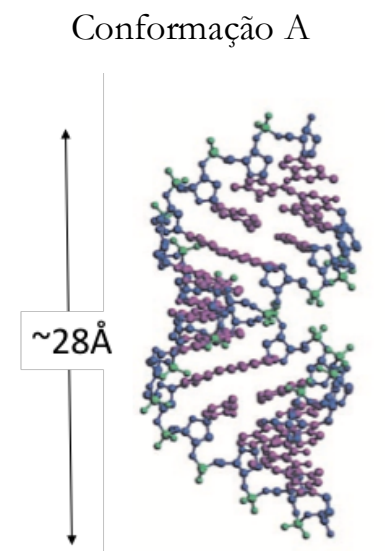

(a)

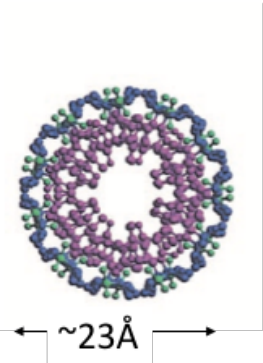

(b)

\section{Conformação B}

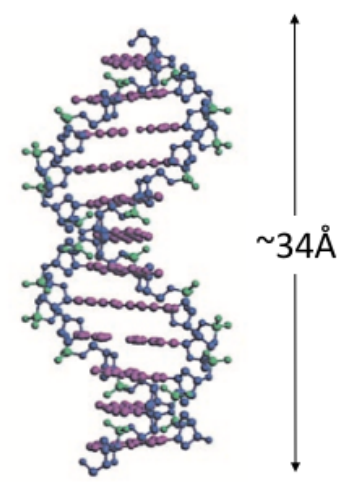

(c)

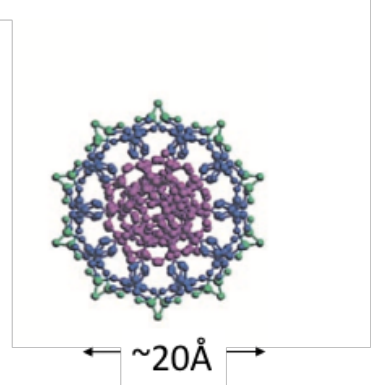

(d)

Figura 0-13 Vista lateral e superior, respectivamente do DNA. (a) e (b) representando o tipo A e (c) e (d) representando o tipo B. Figura adaptada de (Ng et al., 2000).

Mesofases liquido cristalinas formadas por fragmentos de DNA em solução aquosa foram observadas, com uma sequencia de fases; isotrópica (I) ((Figura 0-14 (a)), nemática colésterica $\left(\mathrm{N}^{*}\right)$ (Figura 0-14 (b)) e hexagonal (H) Figura 0-14 (c)), com aumento da concentração. Para fragmentos com 150 pares de bases, essas transições as transições ocorrem para concentrações $160 \mathrm{mg} / \mathrm{ml}$ (I$\mathrm{N}^{*}$ ) e $360 \mathrm{mg} / \mathrm{ml},\left(\mathrm{N}^{*}-\mathrm{H}\right)$ com regiões de coexistência (Livolant e Leforestier, 1996). Já para concentrações superiores à $670 \frac{\mathrm{mg}}{\mathrm{ml}}$, observa-se a fase ortorrômbica (Figura 0-14 (d)). A Tabela 0-1 apresenta um resumo dessas informações. 


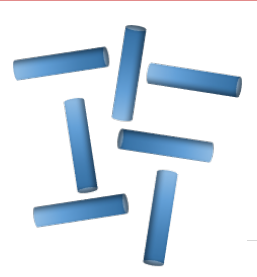

Isotrópica

(a)

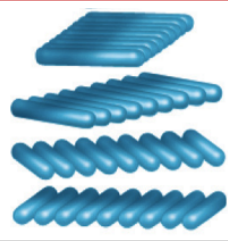

Colestérica

(b)

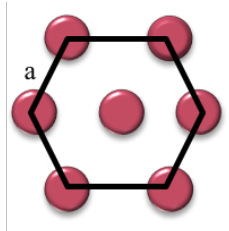

Hexagonal

(c)

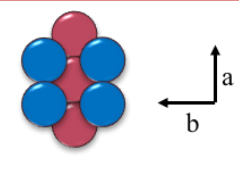

Ortorrombica

(d)

Figura 0-14 Representação esquemática das mesofases observadas para fragmentos de DNA em (a) fase isotrópica, (b) colestérica, (c) hexagonal e (d) ortorrômbica.

Tabela 0-1 Transições de fase em solução aquosa de DNA (50nm) em solução tampão de acetato de amônia a 0,25 M. O domínio de cada estrutura observada é delimitado pela concentração de DNA no solvente ou pela sua fração volumétrica. A distância de separação entre os fragmentos (a) bem como a distância da dupla hélice $\left(\boldsymbol{\delta}_{\text {hélice }}\right)$ são apresentadas abaixo. Extraída da referência (Livolant e Leforestier, 1996).

\begin{tabular}{|c|c|c|c|c|c|}
\hline & Isotrópica & Colestérica & Hexagonal & \multicolumn{2}{|c|}{ Ortorrômbica } \\
\hline $\mathrm{C}_{\mathrm{DNA}}(\mathrm{mg} / \mathrm{ml})$ & $0 \rightarrow \approx 160$ & $\approx 160 \rightarrow 380$ & $\stackrel{2 D}{380 \stackrel{3 D}{\rightarrow} 455^{\rightarrow} 670}$ & \multicolumn{2}{|l|}{$670 \rightarrow 1055$} \\
\hline$\phi_{D N A}$ & $0 \rightarrow \approx 0,1$ & $\approx 0,1 \rightarrow 0,22$ & $0,22 \stackrel{2 D}{\rightarrow} 0,27 \stackrel{3 D}{\rightarrow} 0,4$ & $0,4 \rightarrow 0,62$ & \\
\hline \multirow[t]{2}{*}{ a (nm) } & & $4,9 \rightarrow 3,2$ & $3,15 \stackrel{2 D}{\rightarrow} 2,9 \stackrel{3 D}{\rightarrow} 2,37$ & $a=2,41$ & 2,08 \\
\hline & & & & $\mathrm{b}=3,93$ & 2,97 \\
\hline$\delta_{\text {hélice }}(\mathrm{nm})$ & & & \multicolumn{3}{|c|}{$3,46 \rightarrow 3,02$} \\
\hline
\end{tabular}

As principais características da molécula de DNA relevantes para este trabalho estão apresentadas na tabela a seguir. 
Tabela 0-2 Principais características da molécula de DNA.

\section{Forma A Forma B}

\begin{tabular}{ll}
\hline Comprimento de persistência & $150 \mathrm{pb}$ ou $\approx 500 \AA$ \\
Diâmetro & $\approx 23 \AA \quad 1 \mathrm{e}$ - $\mathrm{\text {nucleotídeo }}$ \\
Carga elétrica & $1,7 \mathrm{~g} / \mathrm{cm}^{3}$ \\
Densidade & $330 \mathrm{~g} / \mathrm{mol}$ de nucleotídeo \\
Massa molar & Baixa $\quad$ Alta diluição \\
Regime de hidratação & diluição
\end{tabular}




\section{Ação de peptídeos em membranas lipídicas}

A interação entre peptídeos (e também proteínas) e fases lamelares é geralmente estudada por meio de técnicas espectroscópicas e ressonância magnética nuclear (NMR) (Nicolau et al., 1974; Sorochkina et al., 2013; Salnikov et al., 2016; Sani e Separovic, 2016) enquanto trabalhos que se propõem a determinar a estrutura destes complexos frequentemente utilizam técnicas de espalhamento (Tsapis et al., 2002; Pabst et al., 2007) . Na maioria dos casos não há a integração dessas duas abordagens, justificando assim a importância do tema tratado neste manuscrito.

Urbach et al (Tsapis et al., 2002) foi o primeiro trabalho disponível na literatura que observa mudanças estruturais em uma fase lamelar composta de um surfactante (tetraethyleneglycolmonododecylether $\left(\mathrm{C}_{12} \mathrm{E}_{4}\right)$ ) e um polipeptídio com 30 resíduos de aminoácidos. Foram empregadas as técnicas de dicroísmo circular (CD), espectroscopia de absorção no ultravioleta e SAXS e observou-se que, embora o polipeptídeo em solução se apresente em uma estrutura secundária tipo random coil, na presença da membrana ele assume uma conformação do tipo $\alpha$-hélice (Figura 0-15).

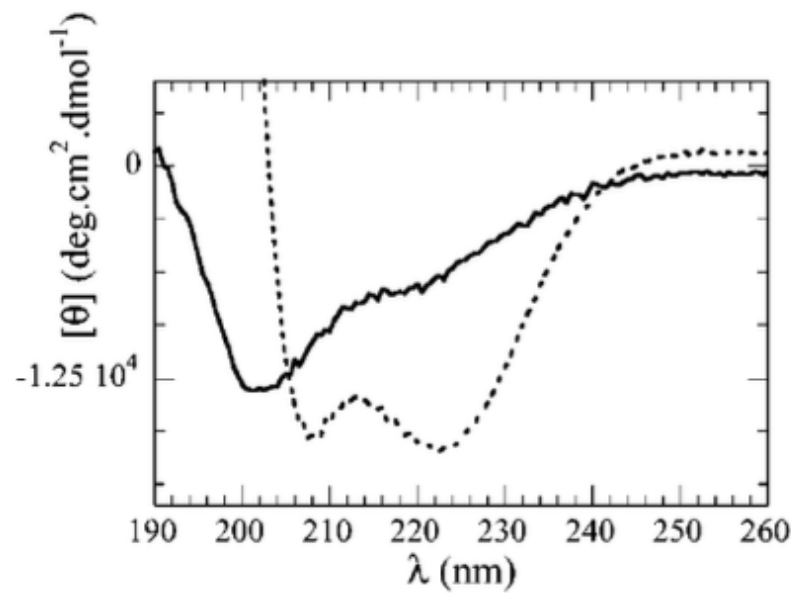

Figura 0-15: $\mathrm{O}$ espectro de $\mathrm{CD}$ para o peptídeo em solução à $28^{\circ} \mathrm{C}$. A linha sólida com uma concentração de $0,83 \frac{\mathrm{mg}}{\mathrm{mL}}$ e linha pontilhada com $0,515 \frac{\mathrm{mg}}{\mathrm{mL}}$. O espectro da linha sólida é característico de uma estrutura tipo randon coil, enquanto o da linha pontilhada apresenta dois mínimos em 208 e 222 nm, característicos da formação da estrutura secundária $\alpha$-hélice. Extraído da referência (Tsapis et al., 2002).

Os dados de SAXS são apresentados na Figura 0-16 (a) para duas frações volumétricas de lipídio, $\phi_{\text {lip }}=0,38$ e $\phi_{\text {lip }}=0,48$, respectivamente. Observa-se que somente a primeira ordem 
do espalhamento de raios-X da fase lamelar, caracterizada por um pico, é apresentada e ajustada. Nesse trabalho utilizou-se o modelo de três degraus para descrever o fator de forma da membrana (Nallet et al., 1989) e a teoria de Caillé modificada para o fator de estrutura (Zhang et al., 1994). A partir do ajuste dos dados experimentais foi estudado o comportamento do parâmetro de Caillé (Figura 0-16b). Para ambas as composições apresentadas o do parâmetro de Caillé decresce com o aumento da razão peptídeo/lipídio. Isto é um indicativo que a estrutura lamelar se torna mais rígida com o aumento da concentração de peptídeo.
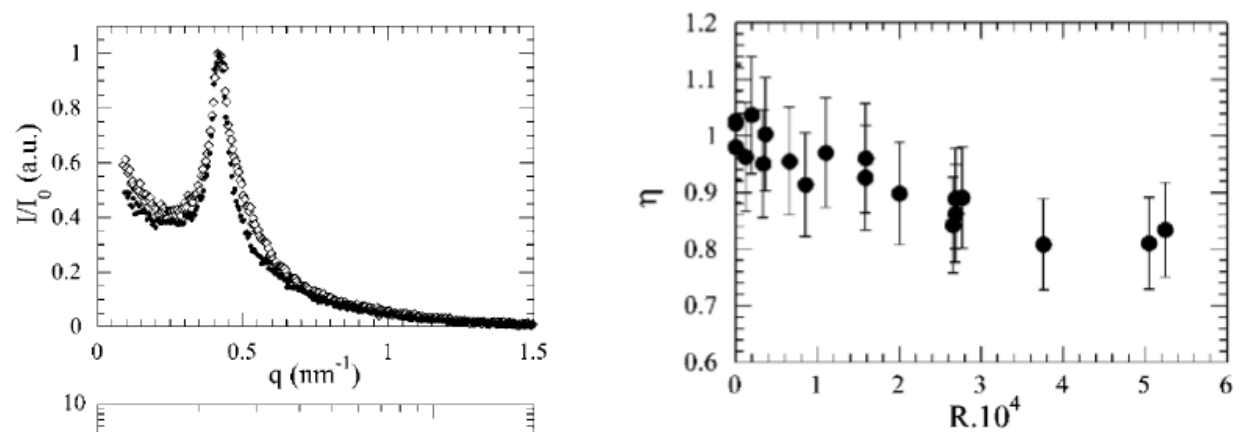

(b)

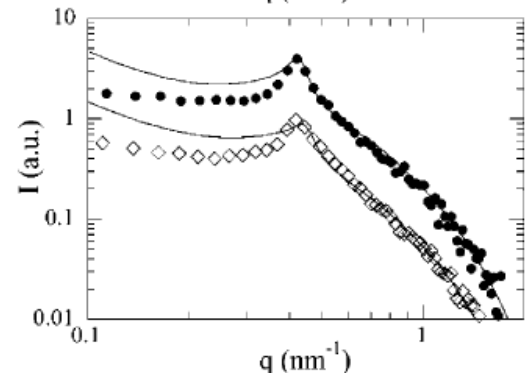

(a)

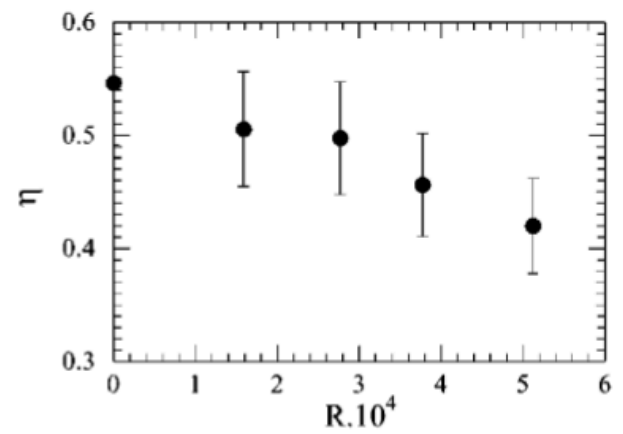

(c)

Figura 0-16 (a) Curvas de espalhamento $I(q) \times q$ para duas frações volumétricas de lipídio, $\phi_{\text {lip }}=0,38$ e $\phi_{\text {lip }}=0,48$, respectivamente. Comportamento do parâmetro de Caillé em função da razão de peptídeo lipídio (b) para $\phi_{\text {lip }}=0,38$ e (c) $\phi_{\text {lip }}=0,48$. Extraída da referencia (Tsapis et al., 2002) .

Outro trabalho também importante, pelo protocolo de preparação de amostras bem como pela análise dos dados de SAXS e pressão osmótica, é o trabalho publicado por Pabst et al (Pabst et al., 2007), no qual os autores investigaram o efeito de um peptídeo antimicrobiano com 21 resíduos (alameticina) em membranas de dioleilfosfatidilcolina (DOPC). Nesse estudo a concentração das amostras foi $50 \mathrm{mg}$ da mistura lipídio/peptídeo para $1 \mathrm{ml}$ de solução aquosa resultando em vesículas multilamelares. Para a análise das curvas de SAXS foi utilizado o modelo de três gaussianas (Pabst et al., 2000) a fim de se descrever o fator de forma da membrana e a teoria de Caillé modificada para o fator de estrutura (Zhang et al., 1994). 


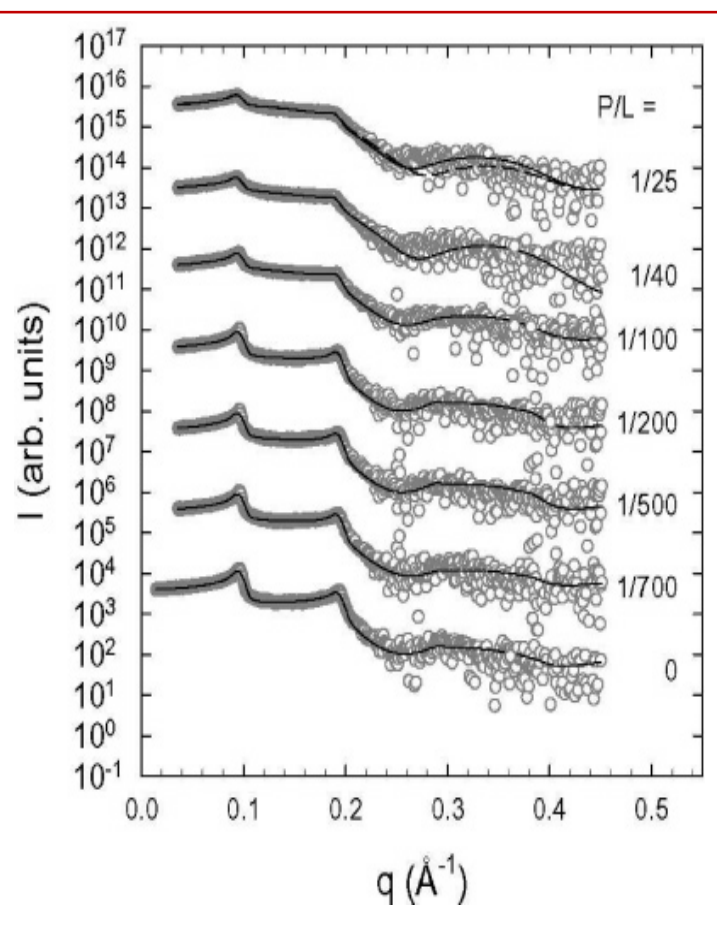

(a)

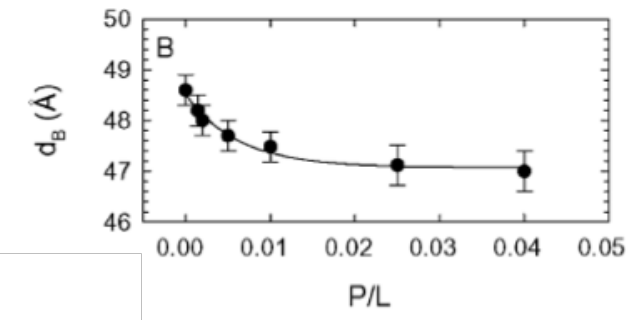

(b)

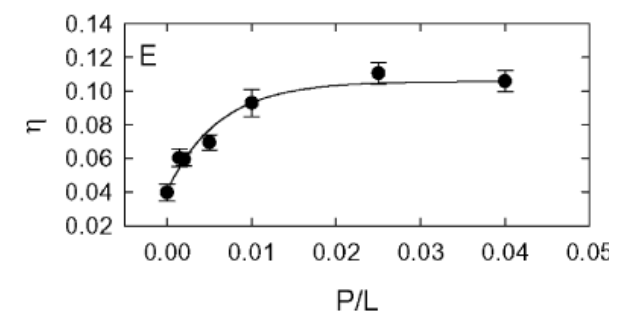

(c)

Figura 0-17 (a) Curvas de espalhamento $I(q) \times q$ variando a razão de peptídeo/lipídio. Comportamento dos parâmetros estruturais em função da razão de peptídeo/lipídio (b) periodicidade lamelar (c) parâmetro de Caillé. Extraída da referência(Pabst et al., 2007).

A primeira diferença em relação ao trabalho anterior é que a curva de espalhamento $I(q) \times q$ apresenta um intervalo maior do módulo do vetor de espalhamento $q$, com os respectivos ajustes, que reproduz satisfatoriamente do comportamento dos dados experimentais (Figura 0-17 (a)). Os valores obtidos dos ajustes para a periodicidade lamelar e o parâmetro de Caillé (Figura 0-17 (b)) mostram que o aumento da quantidade de peptídeo leva à diminuição de 2 Å na periodicidade lamelar e aumento do parâmetro de Caillé, indicando que a estrutura multilamelar se torna mais flexível com o a inserção do peptídeo. Esse resultado é interpretado como sendo resultante da formação de poros nas membranas devido a ação da alameticina.

Outro estudo mais recente sobre interações entre peptídeos e membranas lipídicas é de Hamley et al (Dehsorkhi et al., 2013). Neste trabalho utilizou-se um peptídeo catiônico chamado A6R (6 alaninas e uma arginina), e uma membrana composta por dipalmitoilfosfatidilcolina (DPPC). Para a caracterização deste sistema foram utilizados, entre outras técnicas, CD e SAXS. Os dados de CD mostraram que, ao se adicionar DPPC na solução de A6R, há um deslocamento do mínimo do comprimento de onda em relação ao sinal oriundo apenas da solução de A6R (Figura 0-18 (a)). O mínimo do comprimento de onda em torno de $200 \mathrm{~nm}$ é a assinatura de uma estrutura folha- $\beta$ devido ao peptídeo e que é perdida na presença do lipídio. Ao observar este 
comportamento, os autores chamam atenção para o fato de que o espectro de CD coletado para o sistema DPPC+A6R não corresponde à soma simples dos espectros coletados individualmente para DPPC e A6R. Portanto, existe a formação de um complexo, que foi estudado por SAXS (Figura 0-18b).

As primeiras duas curvas de espalhamento (preta e vermelha) são referentes às amostras contendo apenas DPPC em diferentes concentrações. Para estas curvas observa-se a formação de vesículas multilamelares. A terceira curva (azul) é o peptídeo em solução, a partir da qual é possível concluir que, na região de $q$ observada, não há auto-organização. As últimas duas curvas (ciano e magenta) correspondem ao sistema DPPC+A6R em composições diferentes, que indicam a presença de vesículas unilamelares. Este trabalho fornece a primeira observação da transição de vesículas multilamelares para unilamelares sob a ação de um peptídeo. Nesse caso, o efeito observado se dá pela interação eletrostática entre o peptídeo catiônico e o lipídio zwiteriônico.

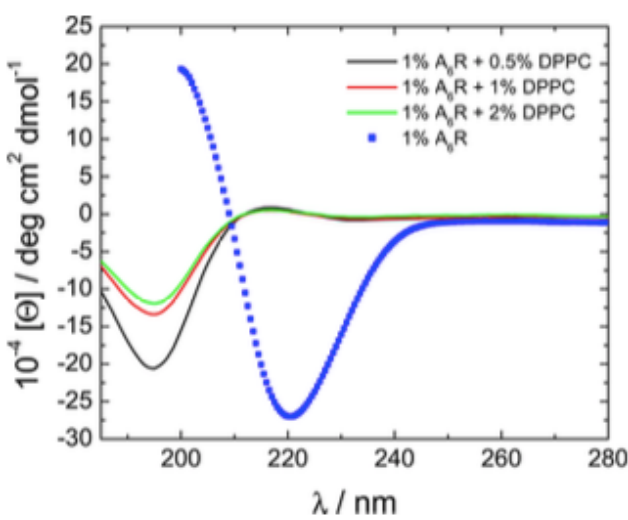

(a)

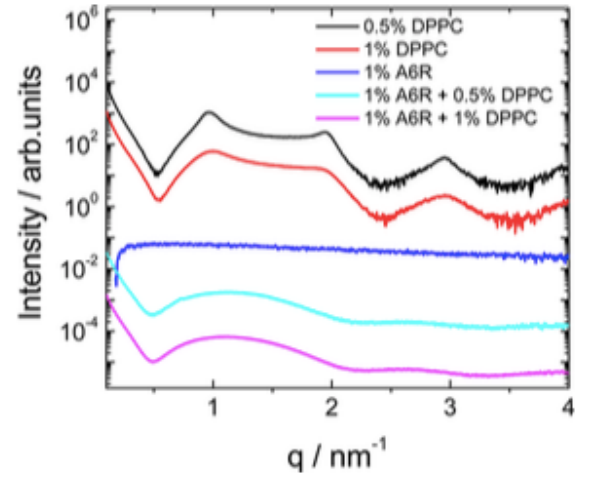

(b)

Figura 0-18 Resultados experimentais para o complexo de DPPC-A6R (a) Espectros de CD e (b) curvas de SAXS. Extraída da referência (Dehsorkhi et al., 2013). 


\section{Complexos de lipídio/DNA}

A preparação de lipoplexos a partir da incorporação de DNA a uma fase lamelar hospedeira tem atraído muita pesquisa, tendo em vista particularmente aplicações em terapia gênica (Luo e Saltzman, 2000; Langer e Tirrell, 2004; Angelatos et al., 2006). Como o DNA é uma molécula altamente aniônica, uma estratégia frequentemente adotada para formulação deste complexo consiste em incorporar esta biomolécula aniônica em um sistema lamelar hospedeiro formado por lipídios catiônicos, valendo-se das interações eletrostáticas (Radler et al., 1997; Smith et al., 1997; Kim et al., 2009; Koynova e Tenchov, 2009).

O primeiro trabalho dedicado ao estudo da interação entre lipídios e fragmentos de DNA foi apresentado por Radler em 1997 (Radler et al., 1997) que demonstrou a formação de complexos utilizando a mistura de lipídios DOTAP-DOPC. A caracterização, utilizando técnicas de difração de raios-X (XRD) e microscopia de fluorescência, revelou a formação de uma fase lamelar com fragmentos de DNA (48502pb e 4361pb) intercalados, e organizados em uma fase esmética bidimensional (Figura 0-19). Nesse caso, as distâncias entre os bastões de DNA variaram entre $25 \AA$ e $70 \AA ̊$, com comprimentos de correlação que compreende 10 moléculas de DNA.

O ordenamento dos fragmentos de DNA depende diretamente do balanço de cargas presentes na membrana e na solução de DNA (Podgornik et al., 1998).

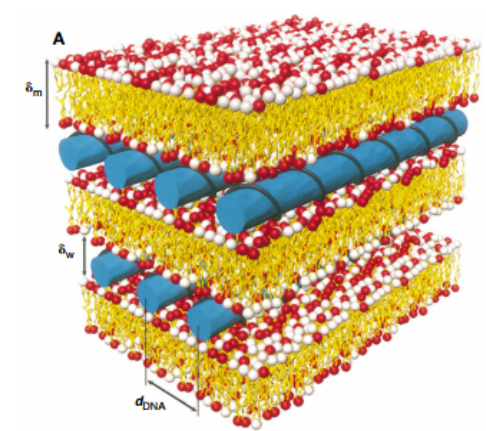

Figura 0-19 Representação de uma estrutura tipo "sanduíche", $\boldsymbol{L}_{\boldsymbol{\alpha}}^{\boldsymbol{c}}$, encontrada por Radler et al (Radler et al., 1997). A fase lamelar é constituída por lipídios e as moléculas de DNA estão inseridas nos canais aquosos entre as bicamadas. Extraída de (Radler et al., 1997).

Embora fases lamelares sejam as estruturas mais frequentes destes complexos, elas não são as únicas encontradas. Arranjos hexagonais formados por lipídios, do tipo "ninho de abelhas", também foram observadas quando utilizados outros tipos de lipídios catiônicos (DOPE/DOTAP) A Figura 0-20(a) representa uma fase hexagonal colunar inversa de lipídeo intercalando DNA 
dentre dos tubos formados de lipídio, enquanto na Figura 0-20(b) representa uma fase hexagonal direta de lipídio, onde os fragmentos de DNA se intercalam entre os agregados de lipídio colunares. (Koltover et al., 1998; Ewert et al., 2006) .

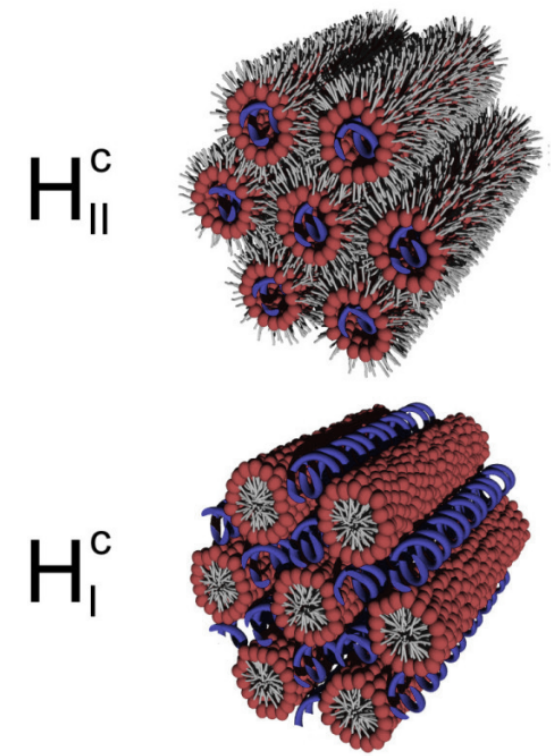

Figura 0-20 Desenho esquemático das fases hexagonais de lipídio tipo colmeia de abelha (a) inversa com os fragmentos de DNA intercalados dentro dos tubos formados pelos lipídios; (b) direta com os fragmentos no interstício da fase lipídica. Extraída de (Koltover et al., 1998; Ewert et al., 2006).

Notemos que estes trabalhos utilizaram interações eletrostáticas para estabilizar tais complexos, porém estudos mais recentes mostram que é possível utilizar outros mecanismos para a estabilização destes complexos usando lipídios neutros, como proposto no modelo de Flory (Colin e Roux, 2002).

Embora a possibilidade de preparação de lipoplexos a partir de lipídios neutros tenha sido demonstrada (Pott e Roux, 2002; Pott et al., 2003; De Oliveira et al., 2010; Da Silva et al., 2011), existem poucos trabalhos semelhantes na literatura. Propõe-se que a formação do complexo seja governada por um mecanismo entrópico relacionado às flutuações térmicas dos fragmentos de DNA e das bicamadas (Colin e Roux, 2002), porém não descreve de maneira satisfatória a variedades de estruturas que tem sido observada, especialmente no regime extremamente concentrado, em que os fragmentos de DNA encontram-se confinados entre as bicamadas e as flutuações térmicas são inibidas.

Pesquisadores do Grupo de Fluidos Complexos (IF-USP) realizaram estudos de propriedades estruturais e dinâmicas de complexos formados por fragmentos de DNA de $150 \mathrm{pb}$ (extraído de tímus de boi) (De Oliveira et al., 2010; Da Silva et al., 2011), utilizando como fase 
hospedeira membranas compostas por lecitina de soja e um co-surfactante comercial Simulsol $^{\mathbb{R}}$ (De Oliveira et al., 2010; Da Silva et al., 2011). Esse co-surfactante é composto por ácidos graxos de cadeias curtas que têm a função de aumentar o intervalo de temperatura para o qual a fase lamelar fluida é estável e conferem mais flexibilidade a estrutura lamelar. Uma das consequências da incorporação dos ácidos graxos é o aumento da distância de separação entre as bicamadas de lecitina permitindo a incorporação de DNA (diâmetro em torno de $2 \mathrm{~nm}$ ) entre as bicamadas (Gerbelli et al., 2013). Existem trabalhos que apresentam diagramas de fases ternários do lipoplexos a partir do qual identifica-se um rico polimorfismo (Da Silva et al., 2011). Além disso, curvas de SAXS desses complexos apresentam um pico difuso entre a segunda e terceira ordem lamelar que é atribuído à incorporação do DNA à fase lamelar (Figura 0-21), observação esta que é corroborada por observações de microscopia ótica e eletrônica (Da Silva et al., 2011). Não obstante, o aparecimento de picos lamelares de ordens superiores (terceira e quarta ordens) indica aumento da correlação entre bicamadas. A presença dos fragmentos de DNA intercalados entre as membranas inibe flutuações térmicas e resulta em enrijecimento da estrutura lamelar, que é observada com a diminuição da largura dos picos de espalhamento em relação a fase lamelar sem DNA.
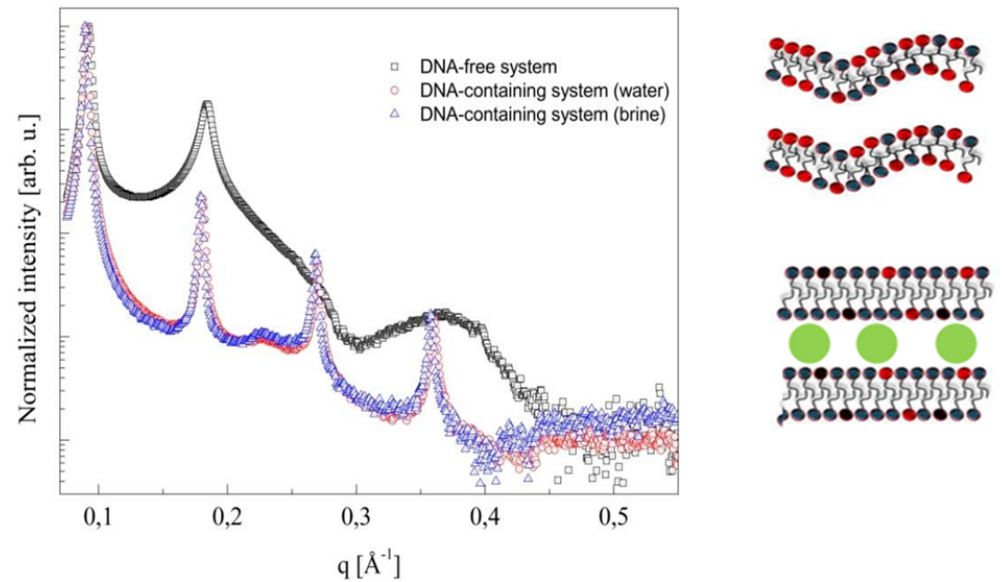

Figura 0-21 Curvas de espalhamento de raios X para o sistema multilamelar composto por bicamadas com $70 \%$ de lecitina e $30 \%$ de Simulsol ${ }^{\circledR}$ e para o complexo. Observa-se que a incorporação do DNA promove o aumento da correlação entre as bicamadas, que se manifesta pela aparição de picos de ordem superior. A adição de sal ao complexo ( $250 \mathrm{mM}$ de acetato de amônia) não produz qualquer tipo de mudança nos parâmetros estruturais. Extraída de (Da Silva et al., 2011).

Da Silva et al (Da Silva et al., 2011), apresentam um diagrama de fase ternário para a fase hospedeira contendo 30\% de ácidos graxos. Neste diagrama estudaram-se três linhas de diluições com três razões de $\rho=\frac{\phi_{l i p}}{\phi_{D N A}}$ (Figura II-21). Para as amostras com maior quantidade de DNA $(\rho=3,1)$ 
foi observado que o complexo apresenta um comportamento monofásico para toda extensão estudada. Esse resultado é compatível com previsões teóricas pois, para essa concentração de DNA relativa ao solvente, é esperada a formação de uma fase ordenada acompanhada da diminuição da entropia rotacional, o que favorece a incorporação do DNA entre as bicamadas de lipídio. No estudo da linha de diluição com complexos $\operatorname{com} \rho=3,1$, na região de alta hidratação os autores observaram uma fase lamelar fluida sem a identificação clara da organização dos fragmentos de $\operatorname{DNA}\left(L_{\alpha}^{?}\right)$

Ao aumentar o confinamento das membranas, os fragmentos de DNA apresentam ordem nemática, isto é, ordem de orientação na camada aquosa. Nesta fase não existe correlação orientacional ou posicional inter-camadas $\left(L_{N}^{\alpha}\right)$. Na região de alto confinamento, os fragmentos de DNA se inseriram na camada aquosa da fase lamelar $\left(L_{\alpha}\right)$ e se auto-organizaram com uma simetria hexagonal 2D $\left(L_{H}^{\alpha}\right)$. O arranjo hexagonal observado traz informações de correlação inter- e intracamada aquosa, pois para este tipo de simetria os fragmentos de DNA devem interagir com os fragmentos que compõe a mesma camada aquosa, bem como com aqueles das camadas vizinhas, apresentando então ordem posicional e orientacional (Figura 0-23 (d)).

Além das estruturas descritas acima, pode-se observar que os fragmentos de DNA podem se organizar em uma estrutura intermediária entre a fase hexagonal e nemática. Esta fase é chamada de retangular centrada (Figura 0-23 (c)).

No mesmo trabalho, Silva et al observou que, para as membranas contendo $50 \%$ de Simulsol ${ }^{\circledR}$, o sistema é monofásico para todas as proporções de DNA estudadas (De Oliveira et al., 2010; Da Silva et al., 2011). Com isso, observa-se que a composição da membrana pode influenciar a estabilização dos complexos. 


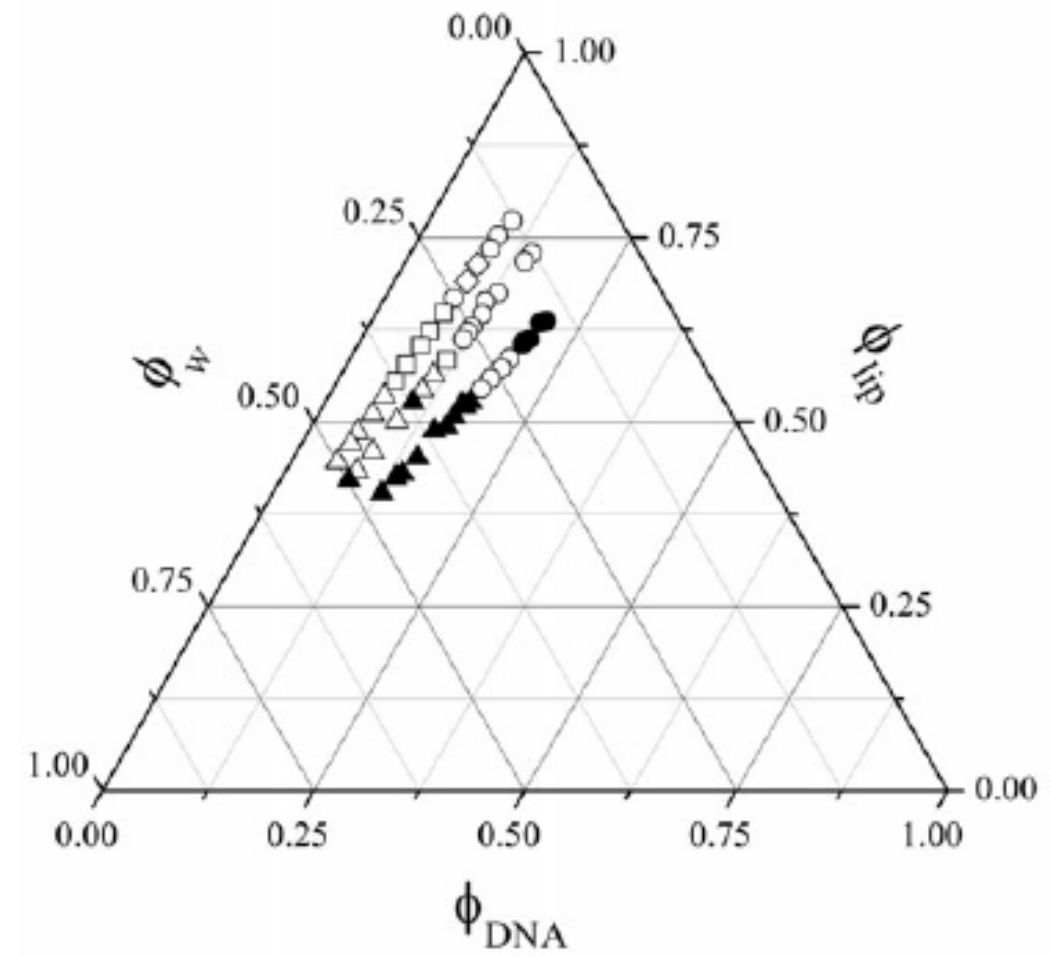

Figura 0-22 Diagrama de fase ternário apresentando como síntese dos principais resultados do estudo de complexos de lipídios neutros com fragmentos de DNA, para três linhas de diluição correspondente a três razões de DNA-lipídios. Os símbolos sólidos indicam domínios monofásicos: $\boldsymbol{\Delta}=\boldsymbol{L}_{\boldsymbol{\alpha}}^{\boldsymbol{N}}, \bullet=\boldsymbol{L}_{\boldsymbol{\alpha}}^{\boldsymbol{H}}$. Os símbolos abertos indicam os complexos com coexistência de fase: $\triangle=\boldsymbol{L}_{\boldsymbol{\alpha}}^{\boldsymbol{N}},+\boldsymbol{L}_{\boldsymbol{\alpha}}^{\boldsymbol{N}}$, ou $\boldsymbol{L}_{\boldsymbol{\alpha}}^{\boldsymbol{N}}+\boldsymbol{L}_{\boldsymbol{\alpha}}^{?}$, o $=\boldsymbol{L}_{\boldsymbol{\alpha}}^{\boldsymbol{N}}+\boldsymbol{L}_{\boldsymbol{\alpha}}^{\boldsymbol{H}}$ ou $\boldsymbol{L}_{\boldsymbol{\alpha}}^{\boldsymbol{H}}+$ $\boldsymbol{L}_{\boldsymbol{\alpha}}^{?}, \diamond=\boldsymbol{L}_{\boldsymbol{\alpha}}^{\boldsymbol{H}}+\boldsymbol{L}_{\boldsymbol{\alpha}}^{\boldsymbol{R} \boldsymbol{C}}, \square=\boldsymbol{L}_{\boldsymbol{\alpha}}^{\boldsymbol{H}}+\boldsymbol{L}_{\boldsymbol{\alpha}}^{\boldsymbol{N}}$ ou $\boldsymbol{L}_{\boldsymbol{\alpha}}^{\boldsymbol{H}}+\boldsymbol{L}_{\boldsymbol{\alpha}}^{?}$. Extraído da referência (Da Silva et al., 2011).

Na Figura 0-23 estão representadas algumas estruturas observadas para este complexo DNAlipídio.

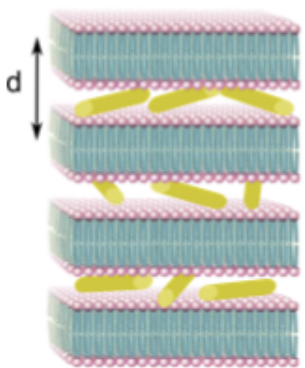

(a)

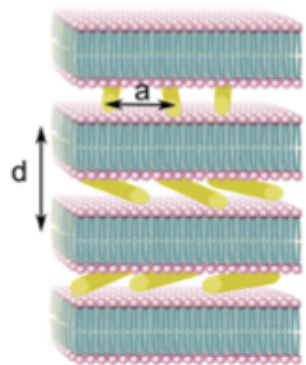

(b)

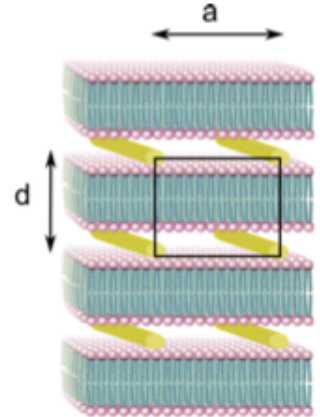

(c)

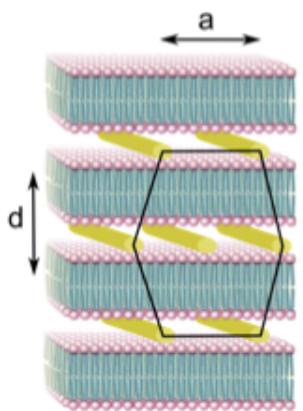

(d)

Figura 0-23 Figura esquemática das possíveis organizações dos fragmentos de DNA inseridos na camada aquosa de uma fase lamelar fluida. (a) $\boldsymbol{L}_{\boldsymbol{\alpha}}^{?}$, (b) $\boldsymbol{L}_{\boldsymbol{\alpha}}^{\boldsymbol{N}}$ (c) $\boldsymbol{L}_{\boldsymbol{\alpha}}^{\boldsymbol{R} \boldsymbol{C}}$ Cada bastão de DNA é separado lateralmente por distância $\boldsymbol{a}$ e verticalmente por uma periodicidade lamelar $\boldsymbol{d}$. (d) $\boldsymbol{L}_{\boldsymbol{\alpha}}^{\boldsymbol{H}}$. O parâmetro a caracteriza a distância entre fragmentos de DNA vizinhos. 


\section{Teoria de espalhamento de raios-X}

O comprimento de onda dos raios-X é da mesma ordem de grandeza da dimensão dos átomos $(\sim 0,1 \mathrm{~nm})$ o que faz com que o espalhamento de raios $\mathrm{X}$ seja uma técnica sensível a densidade eletrônica da amostra com a qual interage. Para um dado comprimento de onda $\lambda$ da radiação incidente, a imagem coletada num detector bidimensional pode apresentar picos de difração que correspondem à interferência construtiva da radiação espalhada. De acordo com a Lei de Bragg, as intensidades relativas diminuem a medida que o ângulo de espalhamento aumenta, isto é, os picos diminuem de intensidade para ordens crescentes de interferência (Figura 0-24).

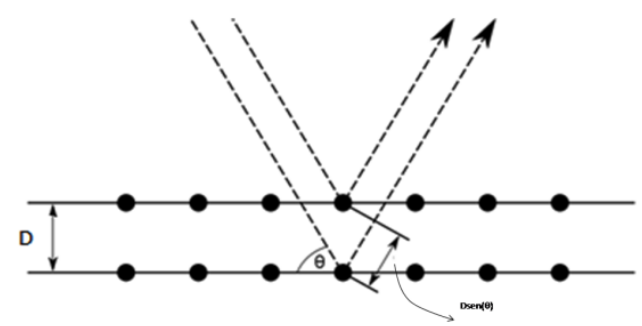

Figura 0-24 Figura esquemática de um arranjo cristalino, onde D é o espaçamento entre os planos cristalográficos e $\theta$ é o ângulo formado entre o feixe incidente com o plano cristalográfico.

Na Figura 0-25 é apresentada uma situação esquemática de espalhamento, sendo $\vec{q}_{0}$ o vetor de onda do feixe incidente e $\vec{k}_{r}$ o vetor de onda refletido (ou espalhado). Define-se então o vetor de transferência de momento no espaço recíproco $\left(\vec{q}_{z}\right)$ como,

$$
\vec{q}_{z}=\vec{k}_{r}-\vec{k}_{i}
$$

onde e $\vec{k}_{r}$ e $\vec{k}_{i}$ são respectivamente (Figura 0-25), os vetores de onda refletido e incidente (Bernard Dennis Cullity 2001). 


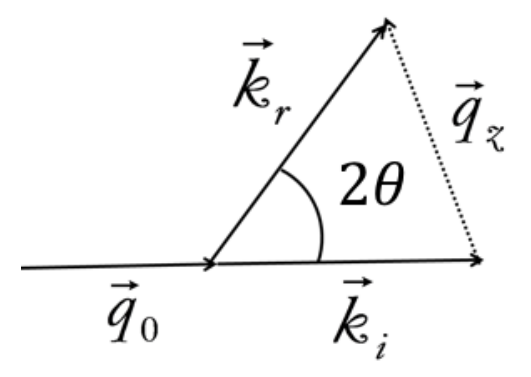

Figura 0-25 Feixe de raios X espalhado por uma partícula $\left(\overrightarrow{k_{r}}\right)$, fixa no espaço, formando um ângulo $2 \theta$ em relação ao feixe incidente. $\mathrm{O}$ vetor de onda $q_{z}$ pode ser descrito pela distância entre os planos cristalinos (Eq 0-3)

$$
q_{z}=\frac{2 \pi}{D}
$$

Para sistemas monocristalinos ou filmes orientados perpendicularmente ao eixo z (Figura 0-26 (a)), o difratograma observado apresenta um padrão de difração de pontos e para um sistema policristalino o espalhamento é isotrópico, formando um padrão anéis concêntricos (Figura 0-26 (b)). A estrutura lamelar resulta em picos ou pontos equidistantes uns dos outros na razão de $q$ de $1: 2: 3 \ldots$

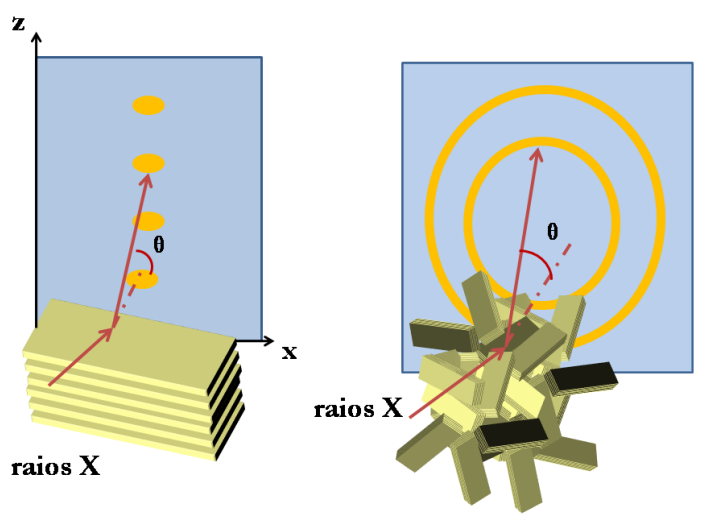

(a)

(b)

Figura 0-26 Representação esquemática do espalhamento de raios-X para (a) sistemas monocristalinos ou filmes orientados e (b) sistemas policristalinos. 
Desde o trabalho pioneiro de Luzatti (Luzzati e Tardieu, 1974) a técnica de espalhamento de nêutrons e raios-X tem sido empregada para o estudo de vesículas e sistemas lamelares (Nallet et al., 1993; Nallet et al., 1994; Baggerjorgensen e Olsson, 1996; Oliveira et al., 2012; Gerbelli et al., 2013; Rubim et al., 2016) . A posição dos picos de Bragg permite a determinação da periodicidade lamelar, porém, devido às flutuações térmicas, há também um espalhamento difuso e esses picos tornam-se largos e não podem ser descritos por funções delta. A análise da intensidade de espalhamento, incluindo o espalhamento difuso, pode fornecer uma descrição mais detalhada da fase lamelar quanto à sua estrutura global, assim como das flutuações térmicas.

Métodos de análise dos dados experimentais de espalhamento que levem em conta não apenas os picos de Bragg mas também o espalhamento difuso tem recebido bastante atenção (Nallet et al., 1993; Pabst et al., 2000; Oliveira et al., 2012) já que informações mais detalhadas podem ser obtidas mesmo quando existem poucas ordens de difração. Esses métodos levam em conta o máximo possível do sinal detectado experimentalmente para garantir a confiabilidade nos valores obtidos e, ao mesmo tempo, devem ser aplicáveis a uma variedade de situações tais como membranas em diversas composições, formando vesículas ou estruturas lamelares (Gerbelli et al., 2013).

A intensidade de espalhamento de um conjunto de camadas espaçadas periodicamente está relacionada á modulação na densidade eletrônica e pode ser descrita como o resultado da convolução da função que descreve a forma e contraste do objeto, o chamado fator de forma $P(q)$, e da função que descreve o arranjo periódico dos objetos e também carrega informações sobre a interação entre eles, o chamado fator de estrutura $S(q)$ : (Glatter e Kratky, 1982)

$$
I(q)=\frac{S(q)\left|P(q)^{2}\right|}{q^{2}}
$$

$\mathrm{Na}$ equação acima, $q$ é o vetor de onda de espalhamento, relacionado ao ângulo de espalhamento $2 \theta$ pela expressão (Eq $0-5$ ), e o fator $q^{2}$ no denominador é uma correção para espalhadores isotrópicos,

$$
q=\left(\frac{4 \pi}{\lambda}\right) \operatorname{sen}(\theta)
$$


onde $\lambda$ é o comprimento de onda da radiação incidente. A função $S(q)$ corresponde à transformada de Fourier da função de rede que descreve o arranjo periódico unidimensional, enquanto a função $P(q)$ corresponde à transformada de Fourier da modulação na densidade eletrônica ao longo de uma célula unitária (bicamada com a camada aquosa). Uma aproximação usual consiste em desacoplar o fator de forma e o fator de estrutura e trata-los separadamente, procedimento este que foi utilizado nesta tese e será descrito a seguir.

\section{Fator de estrutura}

De acordo com a Teoria de Caillé modificada (Caille, 1972; Zhang et al., 1994), o fator de estrutura para um sistema multilamellar, com periodicidade $D$, é descrito de maneira satisfatória por:

$$
S(q)=1+2 \sum_{k=1}^{N-1}\left(1-\frac{n}{N}\right) \cos (n q D) \exp \left[-\left(\frac{D}{2 \pi}\right)^{2} q^{2} \eta \gamma\right](n \pi)^{-\left(\frac{D}{2 \pi}\right) q^{2} \eta \quad \text { Eq 0-6 }}
$$

Na equação acima, $N$ representa o número de camadas correlacionadas na estrutura multicamadas, $\gamma$ é a constante de Euler e $\eta$ é o parâmetro de Caillé (Caille, 1972). Esse parâmetro relaciona as constantes elásticas $\bar{B}$ e $K$ :

$$
\eta=\frac{q_{0}^{2} k_{B} T}{8 \pi \sqrt{\bar{B} K}}
$$

onde $K$ é o módulo de curvatura da membrana e $\bar{B}$ o módulo de compressibilidade a um potencial químico constante. O parâmetro de Caillé é proporcional à flexibilidade das membranas, e para uma estrutura lamelar com membranas extremamente flexíveis, o limite superior teórico é igual 1,3 (Helfrich, 1978).

A Figura 0-27 representa, de maneira esquemática, o efeito das flutuações térmicas na função $S(q)$. Para uma estrutura cristalina unidimensional, formada por bicamadas rígidas, periodicamente espaçadas, a função $S(q)$ seria descrita por picos de Bragg de mesma largura, centrados em $q_{n}=\frac{2 \pi}{D}$, onde $n$ corresponde à ordem de difração. A largura do pico é inversamente proporcional à dimensão do domínio, $L=N D$. Para $N \rightarrow \infty$, a largura dos picos tende a zero, e 
a função $S(q)$ se aproxima de funções delta, com largura finita, determinada pela resolução instrumental. As flutuações térmicas resultam em decaimento da intensidade de espalhamento para as ordens superiores, com um fator de decaimento que é proporcional a amplitude quadrática média das flutuações $\left(\sigma_{\mathrm{s}}{ }^{2}\right)$ e o alargamento dos picos, como representado na Figura 0-27.

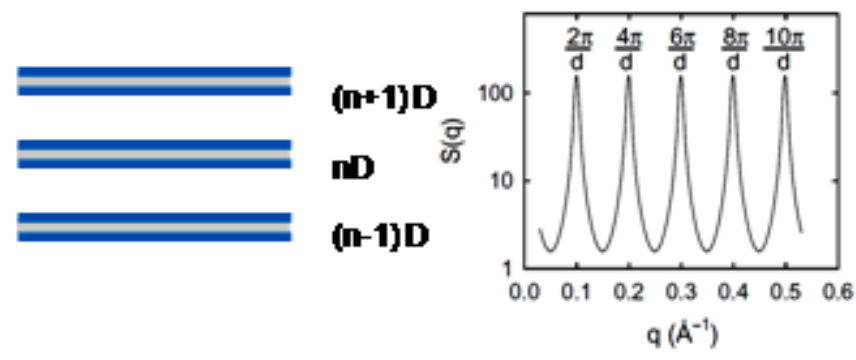

(a)

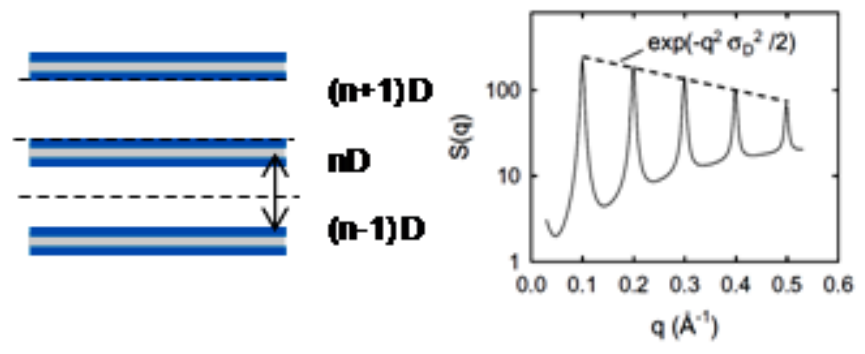

(b)

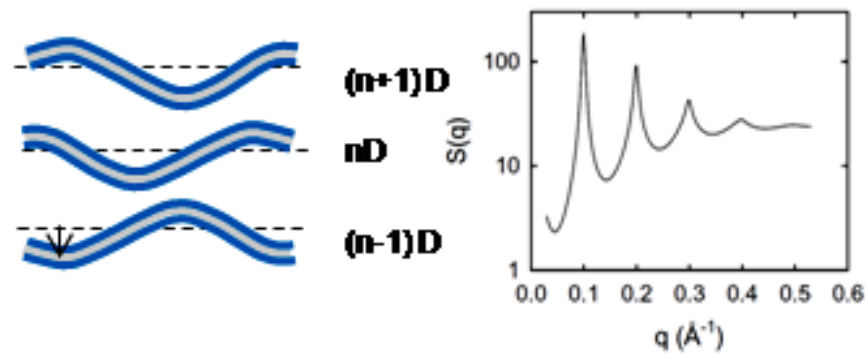

(c)

Figura 0-27: Representação esquemática da fase lamelar e a intensidade de espalhamento $I(q)$ correspondente: (a) para membranas rígidas; (b) com flutuações da periodicidade lamelar (c) com flutuações de ondulações da membrana. Figura adaptada de (Pabst, 2005) . 
O método de decomposição de gaussianas vem se mostrando um método satisfatório para descrever o fator de forma de sistema lamelares compostos de bicamadas simétricas e assimétricas (Oliveira et al., 2012; Balbino et al., 2013; Gerbelli et al., 2013). A função $P(q)$ é a transformada de Fourier da modulação de densidade eletrônica $\rho(z)$ de uma bicamada. Para se construir um perfil

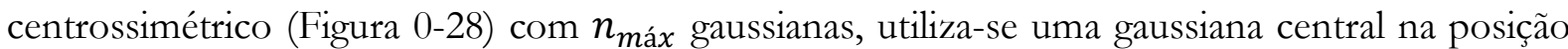
$z=0$, a qual representa as cadeias carbônicas que compõem a bicamada lipídica, e outras $n_{\text {máx }}-$ 1 gaussianas igualmente espaçadas com respeito a $Z=0$, que modelam a região polar. Com isso, o perfil de densidade eletrônico é descrito por:

$$
\rho(z)=\sum_{n=1}^{n_{\max }} \frac{\alpha_{n}\left[G_{s}\left(z, z_{n}, \sigma\right)+G_{s}\left(z-z_{n}, \sigma\right)\right]}{1+\delta_{n 1}}
$$

onde $\delta_{n 1}$ é assume o valor 1 para $n=1$ e o valor 0 para $n=2,3, \ldots, n_{\text {máx }}$. O parâmetro $a_{n}$ representa a amplitude de cada gaussiana dadas pelas funções $G_{s}$ :

$$
G_{s}\left(z, z_{n}, \sigma\right)=\frac{1}{\delta \sqrt{2 \pi}} \exp \left[-\frac{\left(z-z_{n}\right)^{2}}{2 \sigma^{2}}\right]
$$

cujo desvio padrão é dado por:

$$
\sigma=\frac{Z}{2 n_{\max } \sqrt{2 \ln 2}}
$$

onde $Z$ possui relação com a espessura da bicamada. No caso simétrico, a espessura da bicamada é simplesmente $z=\frac{\delta_{m}}{2}$ e a posição de $z_{n}$ é dada por

$$
z_{n}=2 \sigma(n-1)
$$

A transformada de Fourier da densidade eletrônica fornece a amplitude de espalhamento $F(q)$ que se relaciona com o fator de forma, $P(q)=\left\langle F(q)^{2}\right\rangle$. Para bicamadas centrossimétricas, a amplitude de espalhamento será dada por: 


$$
F(q)=\sum_{n=1}^{n_{\max }} \alpha_{n} F(q, n)
$$

onde

$$
F(q, n)=\frac{\sigma}{\sqrt{2 \pi}} \exp \left[-\frac{(\sigma q)^{2}}{2}\right] \cos \left(q z_{n}\right)
$$

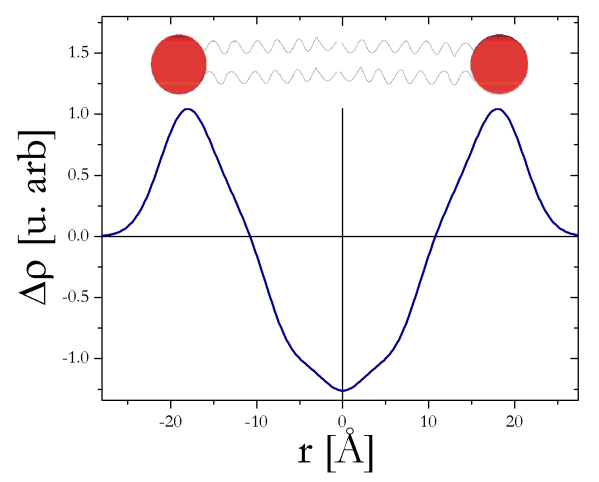

Figura 0-28: Contraste de densidade eletrônico da bicamada obtida com o modelo de 4 gaussianas (Gerbelli, 2012). 


\section{Espectroscopia de infravermelho}

As técnicas espectroscópicas são amplamente utilizadas para estudar sistemas biológicos, pois são capazes de fornecer informações físicas e químicas destes sistemas. Em específico, a técnica de espectroscopia do infravermelho utiliza comprimentos de ondas na região $0,78 \mu \mathrm{m}$ a $1000 \mu \mathrm{m}$. Neste intervalo, é possível obter informações sobre os modos vibracionais dos átomos que compõem o sistema e que por sua vez dependem de como estão ligados entre si. O espectro infravermelho é comumente obtido pela passagem da radiação infravermelho através de uma amostra, e determina a fração da radiação incidente absorvida pela amostra. Esta técnica permite analisar amostras nas formas líquida, sólida ou gasosa, independendo da sua concentração (Stuart, 2004).

Os primeiros instrumentos de espectroscopia do infravermelho (IR) registravam a porcentagem da transmitância ao longo do comprimento de onda. Nos equipamentos atuais não se utiliza o comprimento de onda, e sim o que é chamado de número de onda, que é proporcional a energia de vibração das moléculas e que possui dimensão $\mathrm{cm}^{-1}$. O espectro do infravermelho pode ser dividido em três regiões principais: infravermelho distante $\left(<400 \mathrm{~cm}^{-1}\right)$, infravermelho médio $\left(4000 \mathrm{~cm}^{-1}\right.$ a $\left.400 \mathrm{~cm}^{-1}\right)$ e infravermelho próximo $\left(13000 \mathrm{~cm}^{-1}\right.$ a $\left.4000 \mathrm{~cm}^{-1}\right)$. O intervalo de número de onda que será estudado dependerá das massas relativas, das interações e da geometria das ligações entre os átomos que compõe a amostra em estudo (Stuart, 2004).

Diversas configurações experimentais de IR podem ser utilizadas dependendo do estado da matéria da amostra em estudo (sólido, líquido ou gasoso). As medidas podem ser feitas por transmissão, refletância total atenuada, refletância difusa e refletância especular. Neste trabalho, dado o equipamento disponível e as características das amostras, optou-se por usar o método da espectroscopia de refletância total atenuada (ATR).

A técnica de IR com método ATR utiliza o fenômeno da reflexão interna total (Figura 0-29), onde um feixe incide em um material, que no caso desta técnica é um cristal sobre o qual se deposita uma camada fina do material que se pretende investigar. Quando o ângulo de incidência na interface entre a amostra e o cristal é maior do que o ângulo crítico, ocorre reflexão interna total (Stuart, 2004). 


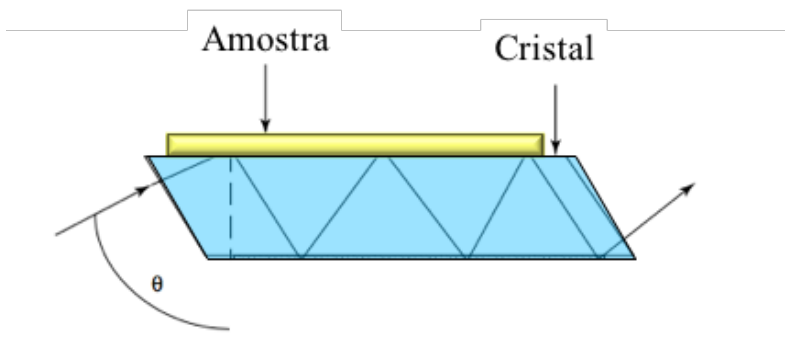

Figura 0-29 Esquema da técnica de IR com método ATR. A radiação incidente sofre o fenômeno de reflexão total no interior do sistema formado pelo cristal e amostra.

A radiação atenuada resultante é medida pela interação do feixe que interage na amostra e parte da energia que é absorvida. As intensidades das bandas podem ser expressas pela transmitância $(T r)$ ou a absorbância $(A b s)$, sendo que a transmitância é a razão entre a energia radiante transmitida pela amostra e a energia incidente e a absorbância é o logaritmo decimal do inverso da transmitância(Stuart, 2004):

$$
A b s=\log _{10}\left(\frac{1}{T r}\right)
$$

De modo geral, o espectro de absorbância de lipídios tipicamente presentes na lecitina, tais como dimiristoilfosfatidilcolina (DMPC) exibem três regiões principais de interesse. Essas regiões correspondem a vibrações associadas às caudas hidrofóbicas $\left(2700 \mathrm{~cm}^{-1}\right.$ a $\left.3000 \mathrm{~cm}^{-1}\right)$ região de interface $\left(1400 \mathrm{~cm}^{-1}\right.$ a $\left.1800 \mathrm{~cm}^{-1}\right)$ e grupos polares $\left(800 \mathrm{~cm}^{-1}\right.$ a $\left.1200 \mathrm{~cm}^{-1}\right)$. Além dessas para números de onda mais elevados (acima de $3000 \mathrm{~cm}^{-1}$ ), também aparecem vibrações associadas à parte polar da cadeia. Na Figura 0-30, é apresentado um espectro típico de membranas de fosfatidilcolinas com as regiões de interesse.

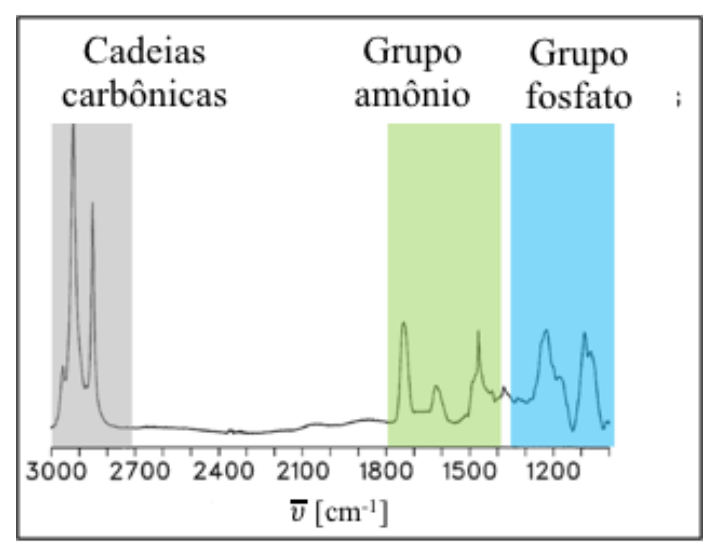

(a) 


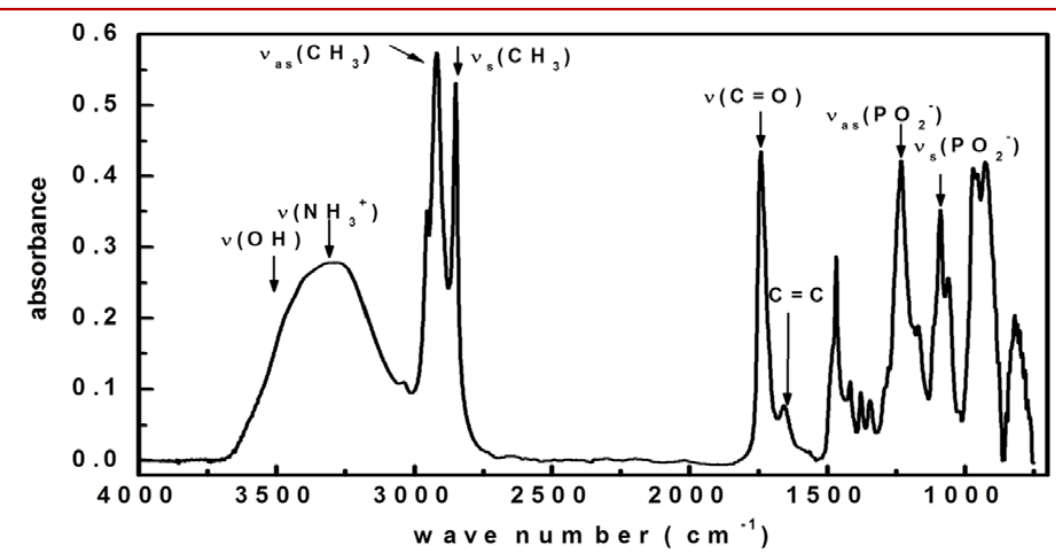

(b)

Figura 0-30 Espectro de IR de um filme de PC em excesso de água. (a) As regiões espectrais destacadas por cores diferentes trazem informação associadas à região hidrofóbica (cinza), interfacial (verde) e sobre grupos polares (azul). (b) Resultados experimentais para o DMPC. Extraídas de (Bridelli et al., 2013).

Na Tabela 0-3, são listadas algumas ressonâncias tipicamente encontradas em lipídios baseados em PC, onde, $v$ representa o estiramento da ligação $O-X$, sendo ela assimétrica (as) ou simétrica (s), e $\delta$ representa a rotação.

Tabela 0-3: Principais grupos funcionais de uma molécula de DMPC (Bridelli et al., 2013).

\begin{tabular}{ccc}
\hline Grupo Funcional & Modo de vibração & Número de onda $\left.\mathbf{( c m}^{-1}\right)$ \\
\hline $\mathrm{R}-\mathrm{OH}$ & $\nu(\mathrm{OH})$ & $3600-3200$ \\
$\mathrm{R}^{-\mathrm{NCH}_{3}}{ }^{+}$ & $\nu\left(\mathrm{NH}_{3}{ }^{+}\right)$ & $3500-3000$ \\
$\mathrm{C}^{-\mathrm{CH}_{3}}$ & $v_{\text {as }}\left(\mathrm{CH}_{3}\right)$ & 2920 \\
$\mathrm{C}^{-} \mathrm{CH}_{3}$ & $v_{\mathrm{a}}\left(\mathrm{CH}_{3}\right)$ & 2850 \\
$\mathrm{RCOOH}$ & $\nu(\mathrm{C}=\mathrm{O})$ & 1744 \\
$\mathrm{H}-\mathrm{O}-\mathrm{H}$ & $\delta(\mathrm{OH})$ & 1600 \\
$-\mathrm{CH}=\mathrm{CH}-$ & $\nu(\mathrm{C}=\mathrm{C})$ & 1657 \\
$\mathrm{O}-\mathrm{P}-\mathrm{O}$ & $v_{\text {as }}\left(\mathrm{PO}_{2}{ }^{-}\right)$ & 1232 \\
$\mathrm{O}-\mathrm{P}-\mathrm{O}$ & $v_{\mathrm{s}}\left(\mathrm{PO}_{2}{ }^{-}\right)$ & 1085
\end{tabular}




\section{E salhame to dinâmi :o de luz}

técnic: e espalhame , dinâmico de 1 z (DLS) permite a let rminação da distribuiçã ho das rtículas atrav da difusão das resmas em um $m$ r o. ı teoria do DLS pode s sor um stema mode de partículas ;féricas em soluçi s. ) luando uma amostra d ; com metro comf ável ao do co tprimento de onc $\downarrow d$ luz incidente, todas a ; difrat ̊̇ em todas as eções (Figura 0 31) (Pecora, 1985; i $\in$ Barron, 2014).

\section{Direção da luz incidente}

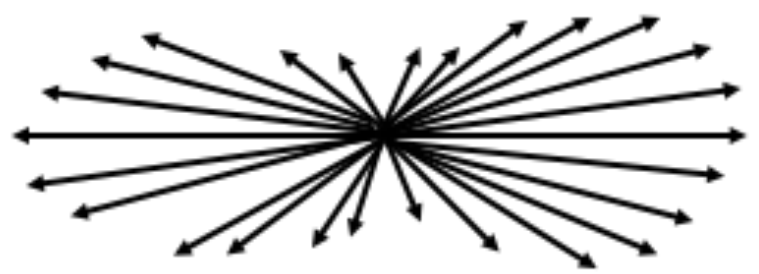

1 Esqur a da difraçãor uma partícula. A aptada de (Li e Barı n, .014).

expre: o do desloc ıento quadrátic médio da partíc la m solução descrita pel tto bror iano é dada $1 \quad \therefore$ (Jones, 2002)

$$
(\overline{S x})^{2}=2 \Delta t
$$

o inter ว de tempo, $\bar{x}^{2}$ é o deslocame to médio quadráti o, $S$ o coeficiente de difusã ıla. O c ficiente de difusão da partícula ode ser calculado ] ela relação de Stokes-Einste $S=\frac{}{6 \pi \eta r}$, onde $k_{b}$ é a constante de Boltzmann, $T$ é a temperatura, $\eta$ é a viscosidade do meio e $r$ o raio hidrodinâmico da partícula.

Como resultado do movimento browniano, a distância entre as partículas muda constantemente e isto resulta em uma sobreposição de ondas espalhadas em função do tempo, causando então flutuações na intensidade de luz coletada em função do tempo. Se as partículas são grandes, as variações de intensidade em função do tempo são menos frequentes, e o contrário acontece para partículas pequenas (Figura 0-32). 


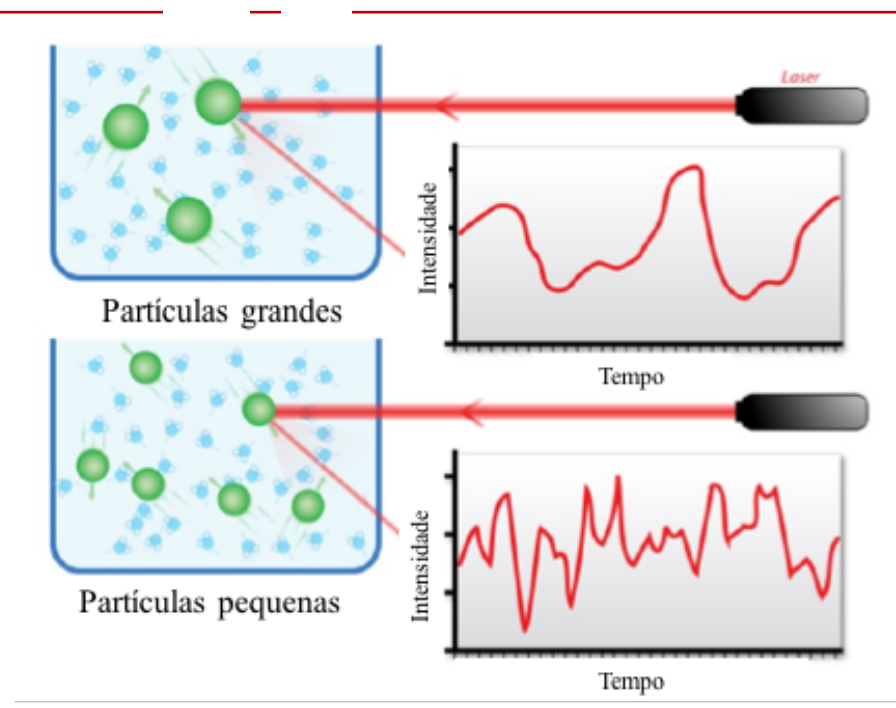

Figur: J-32 Se as partículas s in as flutuações na intensidade coletada não que se as : Irtículas fossem peque Ar ada de (Li e Barron, 2014).

Para descrever a flu o ntensidade em função do tempo utiliza J de autoc relação, descrita com

$$
C(\tau, \quad \rightarrow \infty \quad, I(t) I(t+\tau) d t
$$

onde : é o tempo de corr $\quad, l t$ ) é intensidade em um instante de temf $t+\tau$ ) é a inten: dade em um instante $t+\tau$ e $T$ é o tempo total de observação. A função tocorreção norm lizada da intensidade da luz dispersa em função do tempo do tempo pode ؟ rita como:

$$
C(\tau)=\frac{}{<I(0) I(0)>}=\left[1+\gamma\left[g^{1}(t)\right]^{2}\right.
$$

onde $\gamma$ (fator de coerência) é uma constante medida experimentalmente e a função $g^{1}(t)$ é a função de autocorrelação temporal de primeira ordem do campo elétrico.

Caso não haja interação entre as partículas e o sistema seja monodisperso, a função de autocorrelação do campo elétrico pode ser descrita como uma função de decaimento exponencial:

$$
g^{1}(t)=A+B \exp (-\Gamma \mathrm{t})
$$


onde $\Gamma \overline{\text { é a taxa de decaimento que est }}$ relacionada com o coeficiente de difusão da partícula e com o módulo do vetor de espalhamento $q$ por:

$$
\Gamma=s q^{2}
$$

Com esta relação podemos então utilizar a relação de Stokes-Einsten e determinar o raio hidrodinâmico da partícula. Para partículas pequenas, a função de autocorrelação decai mais rapidamente do que para partículas maiores (Figura 0-33).

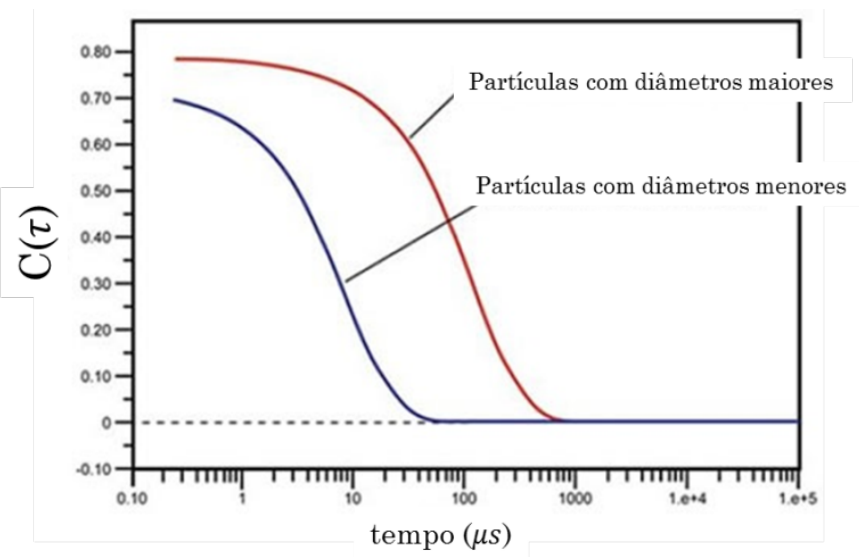

Figura 0-33 Comportamento de uma curva de autocorrelação em função do tempo, para partículas com diâmetro grande e pequeno. Para as partículas com diâmetro menor, observa-se que o decaimento exponencial acontece mais rápido do que as partículas com diâmetro maior. 


\section{MATERIAIS E MÉTODOS DE PREPARAÇÃO}

Neste trabalho foram estudados complexos formados por lipídio e fragmentos de DNA e também constituídos por lipídio e peptídeos. No primeiro caso, a membrana foi composta por uma combinação entre lecitina de soja e o co-surfacante comercial Simulsol ${ }^{\circledR}$ nas proporções de massa (lecitina/Simulsol ${ }^{\circledR}$ ) 30\%/70\% e 10\%/90\%. Já na segunda situação a membrana foi formada apenas por lecitina de soja. Vale destacar que para o estudo dos complexos lipídio-peptídeos foram preparadas vesículas e também fases lamelares, a fim de se explorar diferentes regimes de interação, desde o confinado (pouca água) até o mais diluído. Para tanto, houve a necessidade de se estabelecer um protocolo preciso de preparação das amostras, que será descrito com mais detalhes adiante bem como os materiais utilizados.

\section{Materiais}

\section{Fragmentos de DNA}

O DNA, oriundo do timo de boi, foi obtido da Sigma Aldrich ${ }^{\text {TM }}$ (Brasil), e passou por um processo de dessalinização antes do uso, que consistiu na imersão do DNA em solução de acetato de sódio $3 \mathrm{mM}$ (pH 7) e no armazenamento da mistura em $-80^{\circ} \mathrm{C}$ durante $12 \mathrm{~h}$. Após esse tempo houve o descongelamento e centrifugação da mistura, e ao final o precipitado (DNA dessalinizado) foi coletado. A partir de agora ficará subentendido que o DNA mencionado neste manuscrito será o dessalinizado (ANEXO 1).

Uma das propostas do projeto original foi obter fragmentos de DNA de diferentes tamanhos. Para tanto, num primeiro momento, o DNA foi dissolvido em água deionizada, e misturado até se obter uma solução homogênea, a qual foi armazenada em um freezer. Durante uma semana, diariamente, os tubos foram retirados do freezer e a solução foi agitada para que a hidratação do DNA fosse otimizada. Durante esse processo, a solução, inicialmente túrbida e viscosa, torna-se mais fluida e transparente. Nesse momento, a solução de DNA foi submetida a dois protocolos de sonicação (quebra) num tanque de ultrassom. 
Protocolo A: 30 minutos de sonicação e 30 minutos de repouso (tempo total do ciclo: 1 hora) durante 1 semana.

Protocolo B: 30 minutos de sonicação e 90 minutos de repouso (tempo total do ciclo: 2 horas) durante 2 semanas.

Como a sonicação do DNA se dá pelo fenômeno da cavitação (Kasoji et al., 2015) , o controle da temperatura é fundamental. É conhecido que a sonicação do DNA é mais eficiente em $4{ }^{\circ} \mathrm{C}$ (Biorruptor). Contudo, o aparato experimental permitiu atingir apenas $10{ }^{\circ} \mathrm{C}$ com o auxílio de uma mistura de água e gelo, que era renovada a cada ciclo.

Para a determinação dos tamanhos dos fragmentos de DNA foi empregada a técnica de eletroforese em gel de agarose, representada esquematicamente na Figura 0-1. Basicamente, as soluções de DNA investigadas são depositadas em pequenos "poços" no próprio gel, que se encontra dentro de uma cuba própria para o experimento. Em seguida, uma tensão contínua e constante é aplicada nos extremos da cuba. Como o DNA é carregado negativamente, ele gradualmente migrará para o eletrodo positivo devido à interação eletrostática. A distância percorrida pelos fragmentos sobre o gel será diretamente proporcional ao tamanho dos mesmos. Por meio da comparação dessa distância com aquela percorrida por uma amostra de referência apropriada, o tamanho dos fragmentos pode ser determinado com relativa precisão.

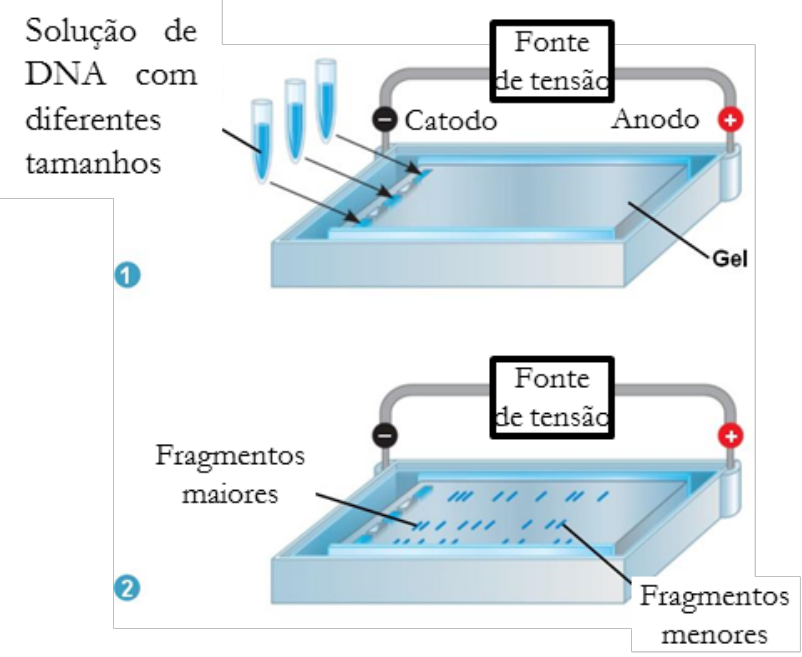

Figura 0-1 Desenho esquemático do experimento de eletroforese. A tensão utilizada na cuba de eletroforese foi de $100 \mathrm{~V}$ e corrente elétrica foi de $150 \mu \mathrm{A}$.

A Figura 0-2 apresenta como exemplo os resultados da eletroforese para o protocolo A. Informações quantitativas foram obtidas com o pacote de tratamento de imagens Image $\mathrm{J}^{\circledR}$, que permite traçar um perfil de intensidade ao longo de uma linha reta escolhida pelo usuário. Nesse 
caso, traçou-se uma linha reta ao longo de cada perfil experimental resultante da corrida do DNA. Os resultados encontram-se na Figura 0-3.

Observa-se, para o Protocolo A, que os fragmentos possuem, após 5 horas, um comprimento médio de $150 \mathrm{pb}$ com uma grande dispersão que diminui a medida em que se aumenta o número de ciclos. É possível se obter fragmentos maiores, entre 1000 e 1500 pb, utilizando-se 2 ou 3 ciclos. Contudo, a polidispersidade de tamanhos é grande, tornando-se um problema na complexação com fases lipídicas, o que pode gerar uma separação de fases acompanhada da completa alteração do equilíbrio termodinâmico do complexo. Resultados semelhantes foram obtidos para o protocolo B.

Em ambos os procedimentos, foi possível a obtenção de fragmentos de 150 pares de base, e razoavelmente monodispersos, que podem ser utilizados para a preparação dos complexos. Contudo, infelizmente foi impossível a obtenção de fragmentos maiores com baixa polidispersidade. Isso é justificado pelo fato de que a cadeia de DNA possui modos próprios de vibração e o acoplamento entre esses modos e o ultrassom é bastante complexo, o que dificulta a obtenção de fragmentos longos e com baixa dispersão. A facilidade em se obter fragmentos de DNA de 150 pares de base reside no fato de que esse é o comprimento de persistência do DNA (P. G. De Gennes 1995) .
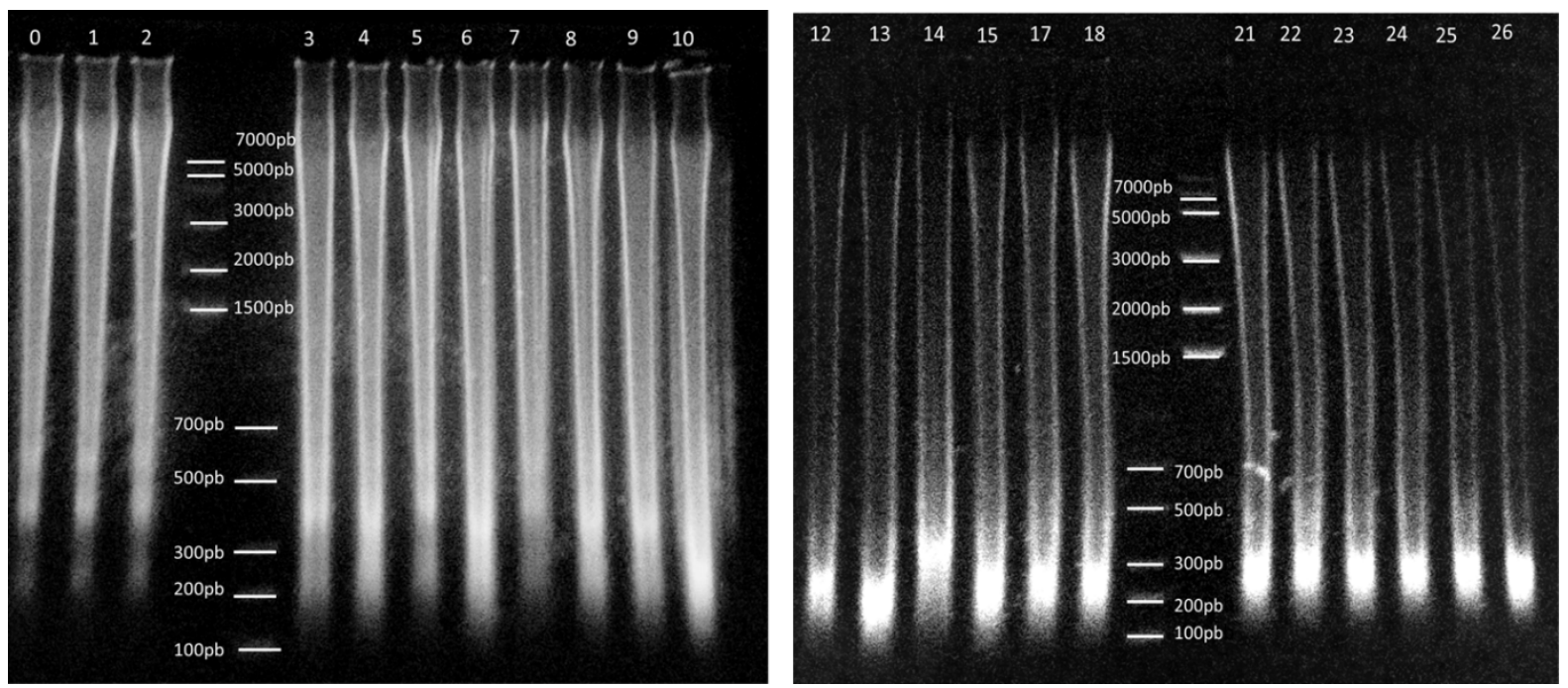

Figura 0-2: Eletroforese de uma solução de DNA submetida a ciclos de 1hora (30 minutos de sonicação seguidos de 30 minutos de repouso). Na figura, os números superiores indicam a quantidade de horas total para a solução. As barras horizontais estão sobrepostas as bandas do DNA de referência, com o número de pares de base indicado ao lado da barra. 

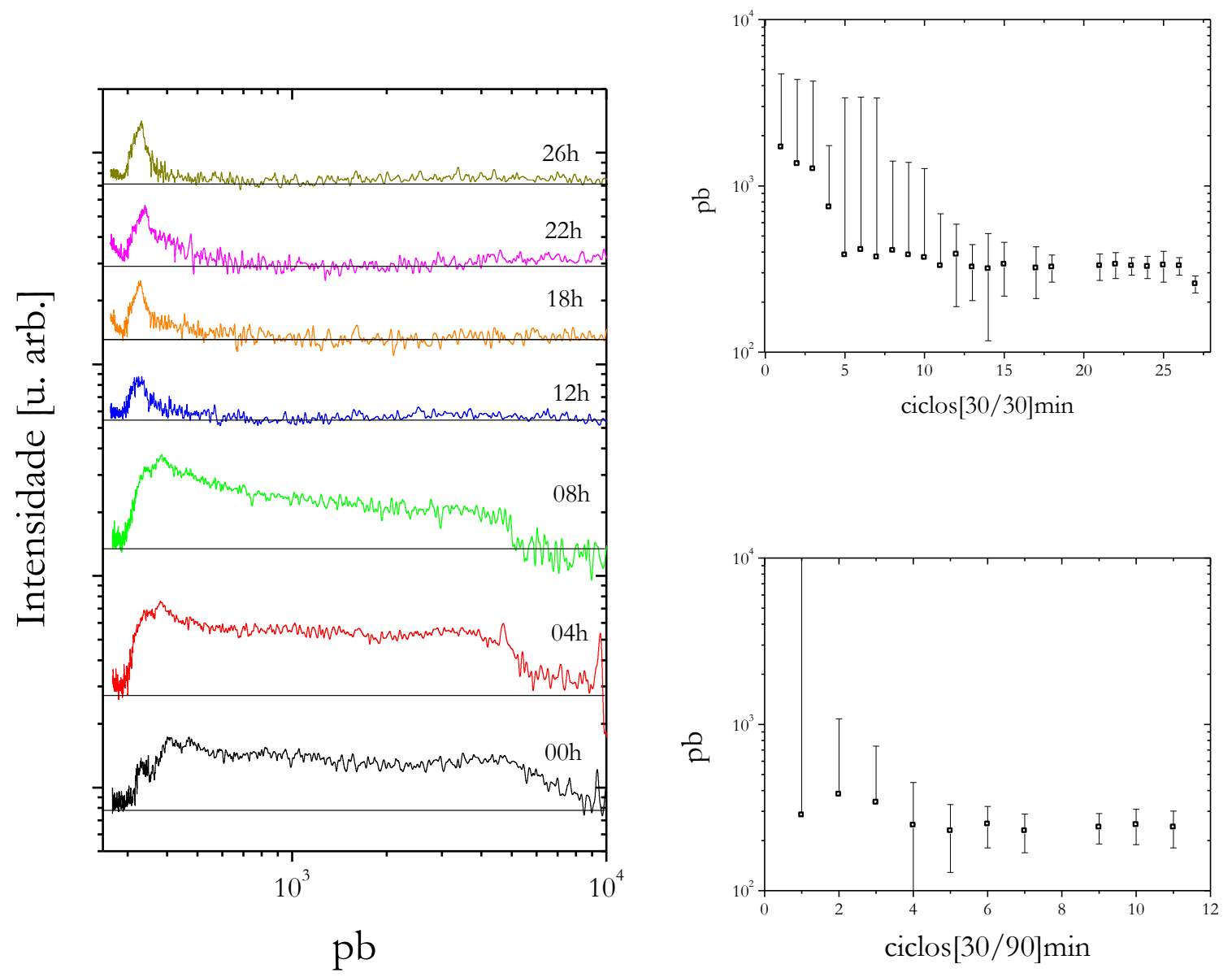

Figura 0-3: Á esquerda: Distribuição de tamanho dos fragmentos de DNA obtidos nos ciclos de sonicação e repouso. Á direita: Evolução do tamanho e polidispersidade dos fragmentos ao longo dos ciclos para soluções com 1 semana de hidratação (superior) e 2 semanas (inferior). As barras representam uma estimativa da largura da distribuição. 


\section{Fase lamelar}

O lipídio utilizado para a preparação das membranas foi a lecitina de soja (Avati Polar ${ }^{\circledR}$ ), que é largamente utilizado em aplicações farmacológicas e utilizada em estudos aplicados a modelos biológicos. No estudo com fragmentos de DNA utilizou-se também um co-surfactante comercialmente conhecido como Simulsol ${ }^{\circledR}$ (Seppic $\left.^{\text {TM}}\right)$.

A lecitina de soja é composta de uma mistura de fosfolipídios, cuja espécie majoritária dilinoleoilfosfatifidilcolina, correspondente a cerca de 63\% da mistura (sua estrutura é apresentada na Figura 0-4a. A segunda espécie com maior abundancia é o dipalmitoilfosfatidilcolina (DPPC), correspondente a cerca de 15\% da mistura. Levando em conta a proporção de fosfoslipídios que constitui a lecitina, calculou-se a sua massa molar média $\left(776 \frac{\mathrm{g}}{\mathrm{mol}}\right)$ e massa específica $\left(1,01 \frac{\mathrm{g}}{\mathrm{cm}^{3}}\right)$.

O co-surfactante Simulsol ${ }^{\circledR}$ é composto de uma mistura de moléculas monocaternárias (compostas de ácidos oleicos e palmíticos) etoxiladas. A cauda carbônica da molécula é funcionalizada a uma cadeia de polietilenoglicol (PEG) com média de 10 monômeros. Sua densidade também pode ser obtida pela média das densidades de seus constituintes, sendo igual a $1,02 \frac{g}{m L}$ (Figura $\left.0-4 b\right)$.

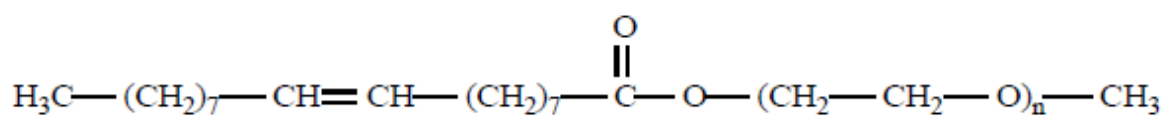

(a)<smiles>CCCCCCC(=O)OCCOOC</smiles>

(b)

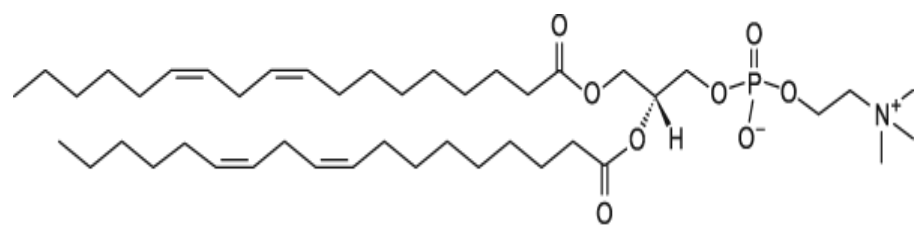

(c)

Figura 0-4: Fórmula estrutural (a) Fórmula estrutural do ácido oleico e (b) palmítico funcionalizados com a cadeia de PEG, onde $<\mathrm{n}>=10$ monômeros e (c) lipídio majoritário da lecitina de soja. 
A lecitina e o co-surfactante, nas proporções desejadas, são co-solubilizados em ciclo-

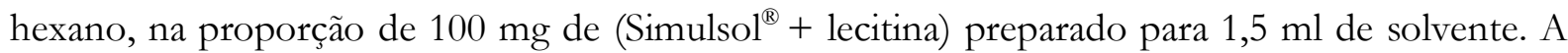
mistura é submetida a ciclos de sonicação até que a solução fique homogênea. A mistura é distribuída em tubos tipo "eppendorf” e colocados em uma estufa à vácuo para evaporação do solvente por um período que pode variar de 24 horas a 72 horas a temperatura ambiente. Esta pré-mistura é utilizada posteriormente na preparação de complexos de lipídios e DNA.

\section{Complexos Lipídio DNA}

No estudo de complexos lipídios e DNA há uma formulação prévia das membranas a serem utilizadas. Foram utilizadas composições distintas, contendo $70 \%$ e $90 \%$ de Simulsol ${ }^{\circledR}$ em massa, respectivamente. Os fragmentos de DNA, previamente sonicados e a mistura de lipídios são co-solubizados em água, em diferentes proporções a fim varrer a linha de diluição. Neste trabalho, a razão entre a fração volumétrica de lipídio e DNA $\left(\rho=\frac{\phi_{\text {lip }}}{\phi_{D N A}}\right)$ foi mantida constante em $\rho=3,1$, pois em trabalhos anteriores para esta razão os lipoplexos apresentaram maiores domínios homogêneos. Para cada composição de membrana foi explorada uma linha de diluição, variando a fração volumétrica de 0,3 á 0,8 .

Foi adotado o protocolo de preparação das amostras, com um volume total $V_{T}=100 \mu \mathrm{L}$, e a pesagem da massa de total realizada em uma balança analítica com precisão de $0,1 \mathrm{mg}$ à temperatura ambiente. Os componentes foram armazenados em tubos tipo "eppendorf" e mantidos em temperatura da ordem de $5^{\circ} \mathrm{C}$.

A homogeneização dos complexos é obtida realizando-se ciclos alternados de centrifugação de 30 minutos, com os tubos de "cabeça para cima" e depois de "cabeça para baixo" juntamente com variações de temperaturas da ordem de $30^{\circ}$. A velocidade de centrifugação utilizada foi de 600 rpm. Este processo foi repetido pelo menos 4 vezes por dia com intervalos de 2 dias de descanso após cada ciclo, durante 1 mês. Para esta etapa do trabalho foram formuladas cerca de 30 amostras, que ficaram estocadas durante 30 dias, à temperatura de $-4^{\circ}$ para atingir o equilíbrio (De Oliveira et al., 2010; Da Silva et al., 2011). 
No estudo da interação de membranas com peptídeos foram escolhidos dois diferentes peptídeos, todos contendo a sequência especifica difenilalanina $(\mathrm{FF})^{1}$. O primeiro peptídeo estudado foi o próprio dímero di-fenialanina (FF) (Sigma Aldrich ${ }^{\circledR}$ ) sua massa molecular da FF é de 312,4g/mol. A segunda sequência é a $\mathrm{CFF}^{2}$ com massa molar de 415,5g/mol (Figura 0-11), a descrição da síntese com maior detalhamento encontra-se no APENDICE A.

FF
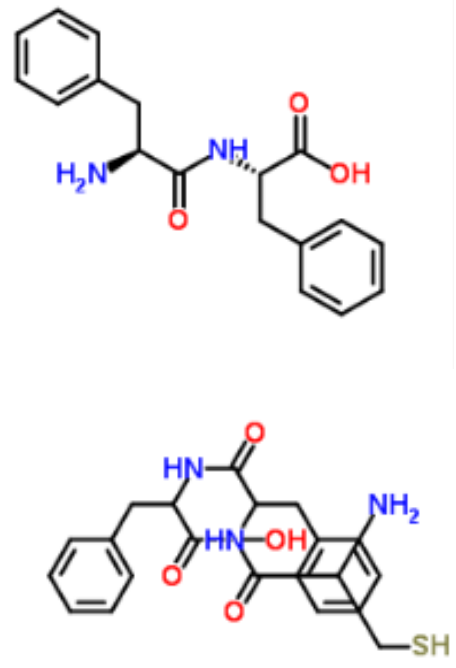

$\mathrm{CFF}$

Figura 0-5: Fórmulas estruturais dos peptídeos curtos.

\section{Preparação de complexos lipídios e peptídeos}

As amostras de lecitina e peptídeo foram preparadas variando a razão molar entre o peptídeo e o lipídio, (P/L). A homogeneização da mistura é obtida misturando-se as quantidades desejadas de cada um dos componentes em uma mistura de solventes orgânicos (clorofórmio e metanol) na razão de 1:1. A mistura é submetida a ciclos de sonicação até que a solução fique homogênea. Para evaporação do solvente a solução é distribuída em tubos tipo "eppendorf” que são colocados em uma estufa á vácuo por períodos que podem variar de 3 dias a 7 dias. Para cada tipo de peptídeo a razão $(\mathrm{P} / \mathrm{L})$ foi variada desde 0,2 até 0,001 .

${ }^{1}$ Os peptídeos aqui serão designados pelo código de letras associado aos aminoácidos constituintes: $\mathrm{F}=$ fenilalanina $\mathrm{C}=$ cisteína.

2 A síntese deste peptídeo foi realizada pela Bruna Ferrante, doutora da Universidade Federal do ABC. 
$\mathrm{Na}$ primeira etapa do trabalho foram preparadas soluções de vesículas, simplesmente adicionando-se água à pré-mistura de lecitina e peptídeo. Para homogeneizar a mistura as amostras passaram pelo processo de sonicação até que o filme fino desprendesse do fundo do tubo de ensaio. Estas soluções passaram por uma ciclagem de temperatura, variando de $-4{ }^{\circ} C$ á $22^{\circ} C$ durante 2 semanas. No dia em que o experimento era realizado as amostras passaram por um processo de sonicação de 4h. Na segunda etapa, para cada razão molar estudada foi explorada a linha de diluição, variando-se a fração volumétrica de lipídio $\left(\phi_{l i p}\right)$ entre 0,85 a 0,2 . Na segunda etapa do estudo, foram formuladas cerca de 300 amostras, estocadas à temperatura de aproximadamente $5^{\circ} \mathrm{C}$, durante 60 dias. 


\section{Métodos}

Nesta seção serão apresentadas as técnicas experimentais utilizadas no estudo de complexos de lipídio com diferentes biomoléculas. Os experimentos FTIR foram realizados com amostras da pré-mistura de lipídios e peptídeos com e sem hidratação. A técnica de DLS foi utilizada para caracterização do tamanho das vesículas preparadas com mistura de lipídios e peptídeos, variando-se o tipo e quantidade de peptídeo incorporado á membrana. A caracterização estrutural dos complexos de lipídios com as diferentes biomoléculas foi realizada por meio de experimentos de SAXS e de espalhamento de raios-X a altos ângulo (WAXS).

\section{Experimentos de SAXS e WAXS}

Os experimentos SAXS e WAXS foram realizados no Laboratório de Fluidos Complexos do Instituto de Física utilizando-se uma máquina convencional Xeuss ${ }^{\circledR}$ da empresa Xenocs ${ }^{\text {TM }}$ (Figura 0-6). O feixe de raios-X é produzido por um ânodo de cobre tipo GENIX, com o comprimento de onda de $\lambda=1,5411 \AA ̊$. O sistema óptico do equipamento consiste em colimadores que geram um feixe quadrado de $0,8 \times 0,8 \mathrm{~mm}^{2}$ e o fluxo do feixe incidente atual é de $1 \times 10^{8}$ fótons/s. O detector híbrido bidimensional, modelo Pilatus $300 \mathrm{~K}$, é composto por três matrizes de detecção totalizando $487 \times 619$ pixels (Figura 0-6 (a)). O feixe direto é bloqueado por um beam-stopper de latão, que contém um pequeno diodo para medir a intensidade transmitida pela da amostra. Em alguns experimentos, foi registrado também o espalhamento a alto ângulo (WAXS) em um detector Pilatus 100K (Figura 0-6 (b)). A distância amostra-detector utilizada para a técnica de SAXS foi de 85 ou $100 \mathrm{~cm}$ que permite acesso a valores de $q$ no espaço recíproco no intervalo de $0,3<q<3,5 \mathrm{~nm}^{-1}$. Para medidas em WAXS a distância utilizada foi de aproximadamente $6 \mathrm{~cm}$ varrendo, no espaço recíproco, o intervalo de $12<q<35 \mathrm{~nm}^{-1}$.

Todos os experimentos foram realizados com a amostra à temperatura ambiente (em torno de $\left.22{ }^{\circ} C\right)$, em pressão atmosférica, e as amostras foram encapsuladas em capilares de vidro de 1,5 $\mathrm{mm}$ de diâmetro médio onde, por centrifugação, as amostras foram depositadas no fundo do capilar. Esse procedimento resulta em uma orientação aleatória das bicamadas no interior do capilar. O sistema de operação do Xeuss permite encontrar a posição ótima para realizar aquisição de dados de cada amostra fazendo uma varredura nas coordenadas de $X$ e $Y$ de cada capilar. A realização da varredura permite ter uma ideia da transmitância das amostras, possibilitando a 
determinação do tempo de exposição para cada uma, que varia de 10 à 60 minutos dependendo da concentração de cada amostra.

Além dos dados obtidos na fonte convencional, experimentos em sincrotron (linha SWING - SOLEIL, França) durante trabalhos anteriores foram usados para comparação e controle. Esses últimos experimentos foram realizados por um aluno de doutoramento (Silva, 2007), porém o tratamento dos dados bem como as análises foram realizados pela autora desta tese.

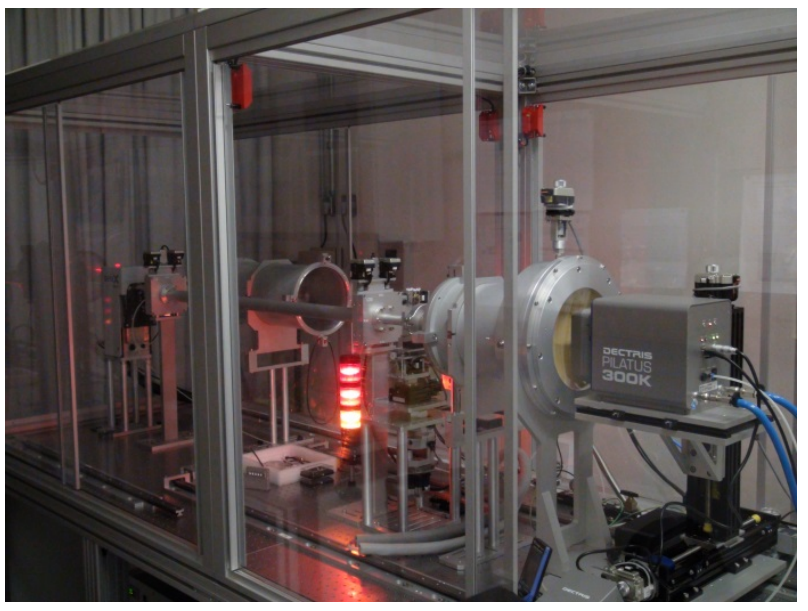

(a)

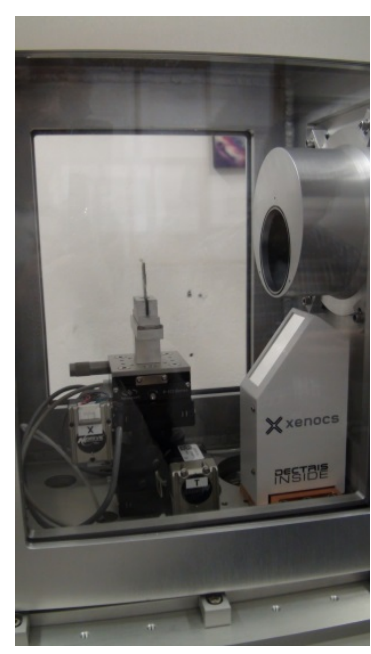

(b)

Figura 0-6: Fonte convencional de raios-X, $X$ euss $^{\circledR}$. (a) Equipamento antes de 2015, com somente o detector de SAXS. (b) Câmara de vácuo e detector de WAXS. 


\section{Métodos de tratamento e ajustes das curvas experimentais}

\section{Redução dos dados experimentais}

A redução das imagens bidimensionais, com correções espaciais e de distorção, para o gráfico unidimensional de intensidade espalhada $I(q)$ versus módulo do vetor de espalhamento $q$ foi feita por meio do programa Foxtrot ${ }^{\circledR}$, fornecido pela Xenocs ${ }^{\mathrm{TM}}$. Para o tratamento posterior dos dados, foi utilizado programa SUPERSAXS (De Oliveira e Pedersen, 2009), desenvolvido pelo Prof. Dr. Cristiano Luis Pinto de Oliveira ${ }^{3}$ do Instituto de Física da Universidade de São Paulo, o qual leva em conta o espalhamento do solvente, do capilar de vidro e também algumas outras correções por meio da expressão (Oliveira, 2005)

$$
I_{\text {tratada }}=\left[\left(\frac{I_{\text {amostra }}(q)}{\Phi_{s} T_{s} t_{s}}-\frac{I_{\text {back }}(q)}{\Phi_{b} T_{b} t_{b}}-\frac{I_{\text {ruido }}(q)}{t_{\text {ruido }}\left(\Phi_{s} T_{s}-\Phi_{b} T_{b} t_{b}\right)}\right) \frac{1}{I_{\text {sombra }}(q)}\right] \frac{\frac{d \sum}{d \Omega_{\text {agua }, 20^{\circ}}}}{I(0)_{\text {agua }, 20^{\circ}}}
$$

onde, $I_{\text {amostra }}$ corresponde ao espalhamento do conjunto amostra+solvente+capilar; $I_{\text {back }}$ corresponde ao espalhamento do solvente+capilar (“background"). As intensidades $I_{\text {ruido }}$ e $I_{\text {sombra }}$ são pré-aquisições que correspondem à corrente de fundo do equipamento e a sombra do feixe direto incidente no "beamstopper", respectivamente. O parâmetro $\Phi_{i}$ representa o fluxo do feixe incidente e os índices $s$ e b indicam "amostra" e "background", respectivamente. A transmitância é representadas pela letra $T$ enquanto $t$ é o tempo de exposição. Para a normalização para a escala absoluta o fator $\frac{d \sum / d \Omega_{a g u a, 20^{\circ}}}{I(0)_{a g u a, 20^{\circ}}}$ utiliza como um padrão secundário a água, que possui um espalhamento relativamente constante na faixa angular estudada. O valor da seção de choque da água é de $0,01632 \mathrm{~cm}^{-1}$ na temperatura à $20^{\circ} \mathrm{C}$.

\footnotetext{
${ }^{3}$ Email para contato: crislpo@if.usp.br
} 
Ajuste das curvas de espalbamento de raios- $X$

A análise dos dados desta tese foi dividida em duas partes:

I) Estudo estrutural de fases lamelares e fragmentos de DNA;

II) Interação entre as fases lamelares e peptídeos.

A análise dos dados das amostras com fragmentos de DNA consistiu apenas na indexação dos picos da curva de SAXS utilizando as expressões que serão descritas na seção Resultados. Já para os dados oriundos da interação entre as fases lamelares e peptídeos, foi utilizado o Método da Deconvolução Gaussiana (descrito na seção 
Fator de forma). É importante mencionar que a análise dos sistemas que não apresentaram fase lamelar consistiu apenas da aplicação da Transformada inversa de Fourier (IFT) (Glatter e Kratky, 1982; Glatter, 2002) que fornece a função de distribuição de distância entre pares (p(r)) e permite a determinação da forma e estimar o tamanho das partículas no espaço real.

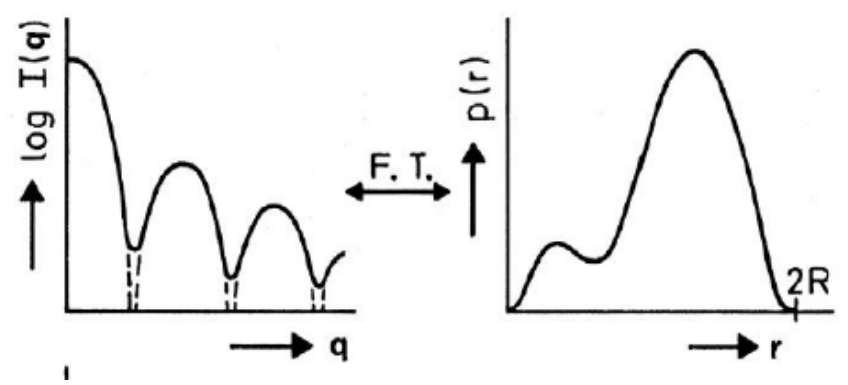

Figura 0-7 Diagrama de Transformadas de Fourier em espalhamento á baixo ângulos. Correlação a função $\mathrm{p}(\mathrm{r})$ e sua transformada de Fourier, a intensidade espalhada I(q), assumindo-se simetria esférica. Figura extraída de (Glatter, 2002)

\section{Determinação da espessura da bicamada}

$\mathrm{O}$ ajuste dos dados experimentais de espalhamento fornece a periodicidade lamelar e o perfil de densidade eletrônica que descreve a bicamada. Neste último, a posição dos picos representa a posição das cabeças polares e enquanto a posição central $(r=0)$ corresponde ao meio da bicamada. O contraste de densidade eletrônico da região é descrito por uma função gaussiana e tomando-se a distância do centro da bicamada até o ponto correspondente a meia altura da gaussiana, tem-se a metade da espessura da bicamada. Nesse ponto pode-se ter uma boa aproximação da interface dos grupos polares da molécula da bicamada e as moléculas de água (Figura 0-8) (Petrache et al., 1998; Nagle e Tristram-Nagle, 2000b; a) . 


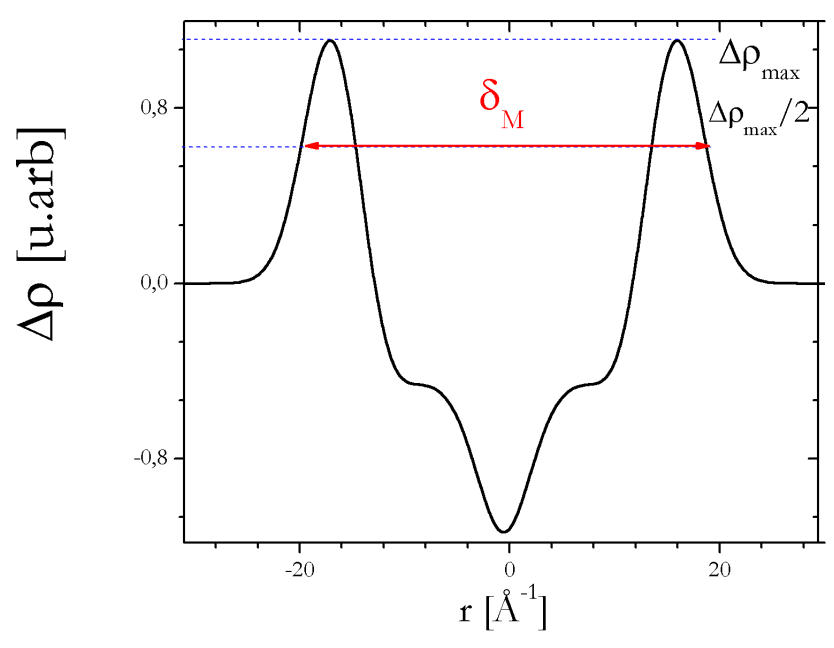

Fi

trônico para uma membrana lipídica Extraída de $\left(\mathrm{G}_{1}\right.$

nte utilizada na caracterização de peptídec

zín

z ligações químicas e determinações indiret: iac

lif

o sistema. Utilizou-se um equipamento de

isc

: Fourier (FTIR), em um espectrômetro

561

, da Universidade Federal da ABC (CEM,

C).

ex

ว ATR com cristal de $\mathrm{KBr}$ em resolução de $2 \mathrm{~cm}^{-1}$ e 100

ac

jis intervalos de números de onda que são de interesse no es $0-1800 \mathrm{~cm}^{-1}$, onde as vibrações associadas aos grupos fosfato e colina, e $2800-3050 \mathrm{~cm}^{-1}$, relacionadas às vibrações das caudas carbônicas (Bridelli et al., 2013). Os espectros finais correspondem a média dos espectros acumulados com subtração do fundo. $\mathrm{Na}$ análise foram identificados os números de ondas para os quais houveram deslocamentos significativos, bem como aqueles que tiveram a intensidade relativa alterada pela presença do peptídeo. 


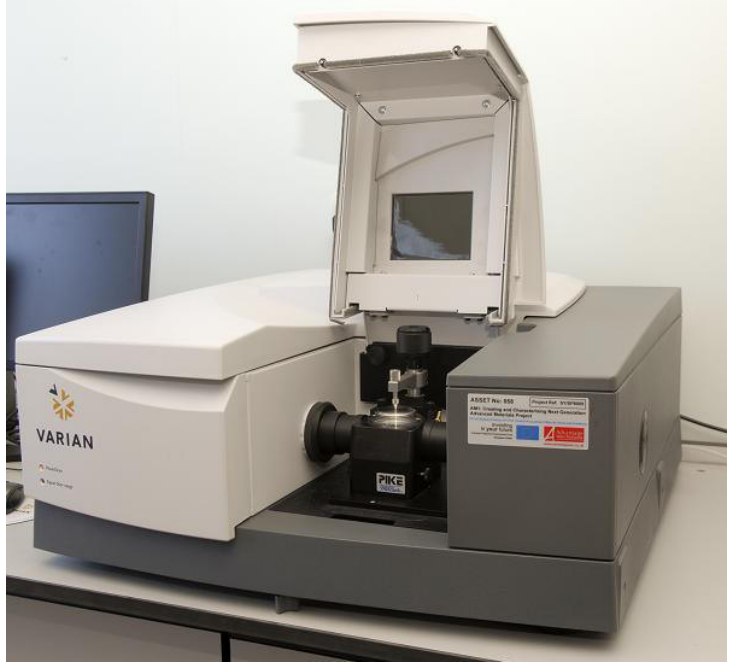

Figura 0-9: Equipamento de FTIR da empresa Varian 660, em modo ATR, localizado no laboratório CEM da UFABC.

Os experimentos foram realizados em duas séries de amostras diferentes. A primeira, com filmes finos preparados a partir da pré-mistura de lipídios e peptídeos, e a segunda série, com uma mistura de peptídeo-lipídio hidratada e mantendo a fração volumétrica de lipídio fixa $\left(\phi_{\text {lip }}=0,4\right)$. Para ambas, os espectros foram obtidos variando-se a quantidade de peptídeo na pré-mistura.

\section{DLS}

Os experimentos de DLS, são muito utilizados para a caracterização de sistemas compostos de vesículas, uma vez que ele permite ter informações sobre polidispersidade e a distribuição de tamanhos. Foi utilizado uma máquina comercial da Brookhaven 90 Plus, com comprimento de onda de 0,635 $\mu \mathrm{m}$, instalado no laboratório de Fluidos Complexos no IFUSP (Figura 0-10). Os experimentos foram realizados à temperatura ambiente e as amostras foram colocadas em cubetas plásticas especiais fornecidas pelo próprio fabricante. A distribuição de tamanhos pode ser obtida pelo ajuste da função de autocorrelação, e neste trabalho foi utilizado o método de cumulantes com simetria esférica (Koppel, 1972). 


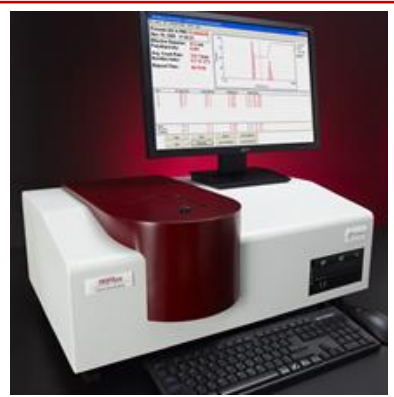

Figura 0-10 Máquina de DLS -Brookhaven 90 Plus. Extraído de https://www.brookhaveninstruments.com/nanobrook-173plus-particle-size-analyzer

\section{Dicroísmo Circular}

O dicroísmo circular (CD) é particularmente útil para o estudo de moléculas quirais, tais como proteínas, DNA, etc. Esta técnica é a espectroscopia na região do espectro UV, que mensura a diferença na absorbância da luz circularmente polarizada. Este fenômeno é rotineiramente utilizado no estudo da estrutura secundária de proteínas e peptídeos. Na Figura 0-11 pode-se observar a curva de CD para as três possíveis estruturas secundárias. Para a estrutura $\alpha$-hélice, observa-se a sequência de um máximo seguido de um mínimo em $192 \mathrm{~nm}$ e $209 \mathrm{~nm}$, respectivamente. Para a folha- $\beta$ observa-se a sequência de um máximo seguido de um mínimo em $196 \mathrm{~nm}$ e $218 \mathrm{~nm}$, respectivamente. Já para a estrutura tipo random coil observa-se a sequência de um mínimo seguido de um máximo em $195 \mathrm{~nm}$ e 212 nm, respectivamente.

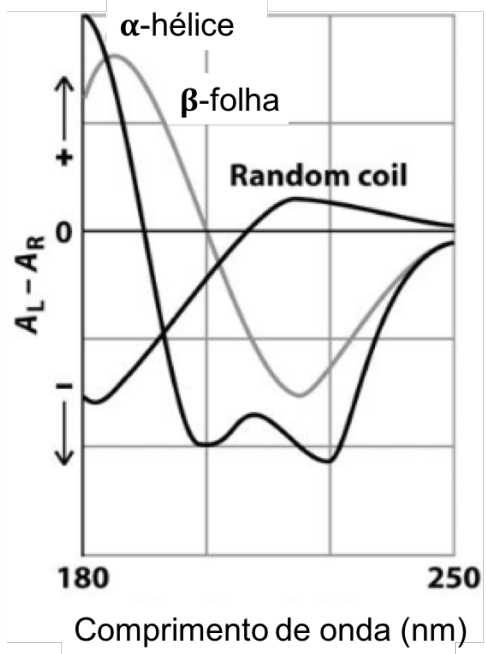

Figura 0-11 Espectro de CD teórico para as estruturas secundárias. Figura extraída de (W. e Freenman, 2006). 
Os ensaios de CD foram realizados em um equipamento JASCO 810 (Figura 0-12), multiusuário, instalado na Universidade Federal de São Paulo. Durante as medições o instrumento foi mantido sob saturação de $\mathrm{N}_{2}$ à temperatura fixa de $22^{\circ} \mathrm{C}$. As soluções de peptídeo-lipídio foram depositadas em um porta amostra Hellma ${ }^{\circledR}$ feito de placas de quartzo desmontáveis com espessura variável de $0,1 \mathrm{~mm}$ a $1 \mathrm{~mm}$, dependendo da concentração da amostra. As varreduras foram registradas na faixa de comprimento de onda $190 \mathrm{~nm}-260 \mathrm{~nm}$, com passos de 0,5 $\mathrm{nm}$, velocidade de $20 \frac{\mathrm{nm}}{\text { minuto }}$ e largura de banda de $1 \mathrm{~nm}$. O dado final correspondeu à média de quatro acumulações com subtração de background (neste caso, a água). A tensão fotomultiplicadora foi mantida abaixo de $500 \mathrm{~V}$ em toda a faixa medida para garantir níveis adequados de absorbância. Os dados foram normalizados pela concentração de peptídeos e pela espessura do porta amostra a fim de permitir a comparação entre diferentes formulações.

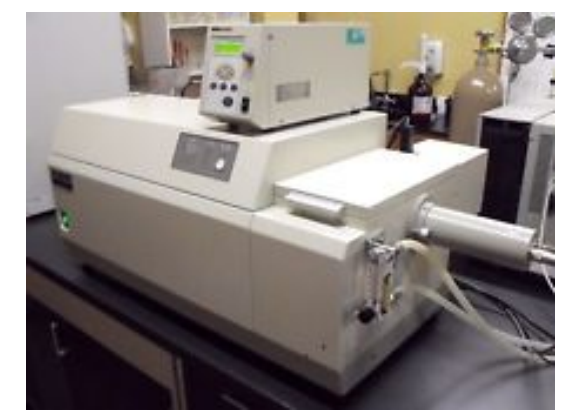

Figura 0-12 Equipamento de Dicroísmo Circular, JASCO 810, localizado no laboratório de Biofísica da Unifesp. 
Microscopia de luz polarizada e de fluorescência

O principal objetivo destas observações foi avaliar a birrefringência óptica das amostras. Para o complexo DNA-lipídio, pode-se obter informações acerca da uniformidade na distribuição de DNA no interior do complexo. Para os complexos de peptídeo-lipídio, é possível se observar as texturas das fases lamelares, bem como a provável cristalização dos peptídeos. Na Figura 0-13 (a), observa-se a formação de cruz de malta que, para sistemas formados de partículas anisotrópicas, corresponde a um indicativo de uma fase nemática. Na Figura 0-13 (b) é apresentada a textura típica de uma fase lamelar, com orientação preferencial homeotrópica, com alternância de zonas claras e escuras entre polarizadores cruzados.

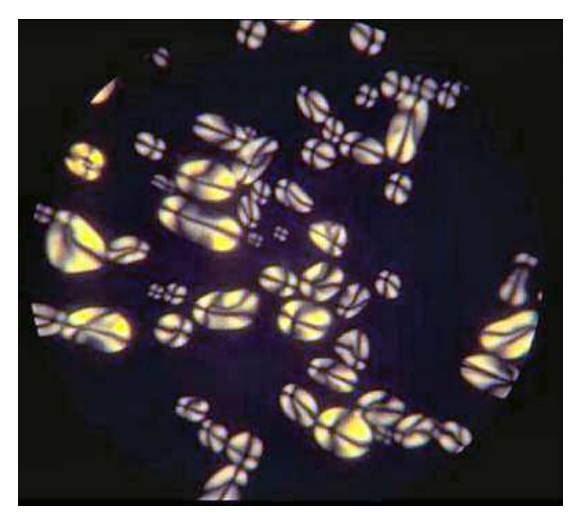

(a)

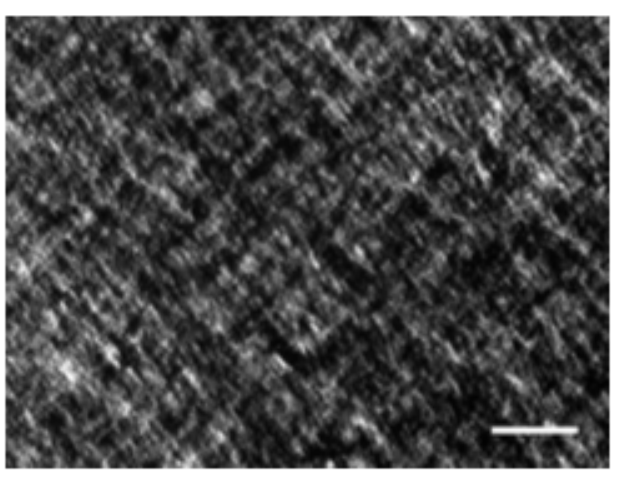

(b)

Figura 0-13 Texturas de microscopia de luz polarizada (a) Cruzes de maltas formadas por agregados de amido Extraído de http://www.sbfgnosia.org.br/Ensino/amido.html (b) textura de fases lamelares onde padrões caóticos de claro e escuro são observados (Silva, 2007).

O instrumento empregado em ambas análises foi um microscópio Leica ${ }^{\circledR}$, modelo CTR Mic (Figura 0-14). Trata-se um microscópio invertido, onde a iluminação pode ser realizada tanto por uma lâmpada de filamento quanto por uma fonte de mercúrio. 


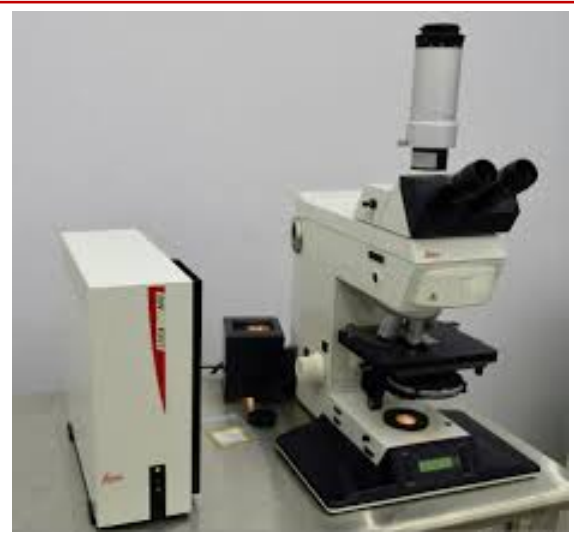

Figura 0-14 Microscópio de luz polarizada e de fluorescência Leica CRT Mic, , localizado no laboratório do grupo de Fluidos complexos da USP.

\section{Microscopia confocal}

Para os complexos peptídeos-lipídios, em excesso de água foram realizadas observações de microscopia ópticas em um confocal Leica ${ }^{\circledR}$, modelo TCS SP8, multiusuário, instalado na Universidade Federal de São Paulo. As soluções de peptídeo-lipídio foram colocadas sobre lâminas de vidro e rapidamente fechadas com uma lamínula. Para evitar a evaporação durante o procedimento de coleta de imagem, o conjunto foi selado com esmalte de unhas. As imagens foram coletadas usando o modo de contraste de fase, com uma objetiva opera seca de $40 \times$ e um pinhole com abertura de 1 unidade Airy que fornece a profundidade do campo superficial e remove o brilho dos objetos fora de foco. O tratamento e edição da imagem foram realizados com o software LAS $\mathrm{X}^{\circledR}$, fornecido pelo fabricante do microscópio. 


\section{RESULTADOS EXPERIMENTAIS}

Neste capítulo serão apresentados os resultados experimentais para os dois complexos estudados. O primeiro sistema apresentado é constituído de uma fase lamelar (lecitina de soja e Simulsol $^{\circledR}$ ) e fragmentos de DNA. Foi realizado o estudo estrutural destes complexos para duas composições distintas de membrana, uma composta de 30\% de lecitina e 70\% de Simulsol ${ }^{\circledR}$ e outra com $10 \%$ de lecitina e $90 \%$ de Simulsol ${ }^{\circledR}$ em massa.

O segundo sistema apresentado é composto por membranas formadas por uma mistura de lecitina e peptídeos, variando-se a razão molar entre peptídeos e lipídios, $P / L$. Foram utilizados dois tipos de peptídeos: FF e CFF. Em um primeiro momento será apresentado o estudo em excesso de água, que promove a formação de vesículas, seguindo com sistemas compostos de fases lamelares e FF explorando a linhas de diluição. Ao variar a hidratação é possível acessar diferentes regimes de interação entre as membranas, e estudar de maneira sistemática as propriedades estruturais e elásticas da fase lamelar.

\section{IV.I. Complexos de lipídios e DNA}

O estudo das propriedades estruturais dos complexos de lipídios e DNA consistiu de duas séries, com composições de membrana 70\% e 10\% de Simulsol, respectivamente. A linha de diluição foi varrida mantendo-se constante a razão entre a fração volumétrica de lipídios e DNA em 3,1. Em estudos anteriores (Silva, 2010) a fase lamelar hospedeira era composta por 70\% de lecitina, mas o presente estudo focou em composições mais ricas em Simulsol ${ }^{\circledR}$, já que as membranas possuem maior flexibilidade e para as quais espera-se encontrar as cadeias de PEG na conformação estendida. Não foi possível explorar o regime com pouco co-surfactante, pois as distâncias de separação entre as bicamadas $\left(\delta_{W}\right)$ são tipicamente menores que $2 \mathrm{~nm}$, impossibilitando a inserção de fragmentos de DNA cujo diâmetro é cerca de $2 \mathrm{~nm}$.

Para a identificação das estruturas, foram combinadas as técnicas de microscopia de luz polarizada, fluorescência (DNA marcado com $Y O Y O^{\circledR}$ ) e SAXS. Na Figura 0-1 são apresentadas curvas de espalhamento para a composição com 30\% de lecitina e ao lado as fotos que indicam as texturas observadas para algumas amostras, tanto em fluorescência (em verde) quanto em polarização. 

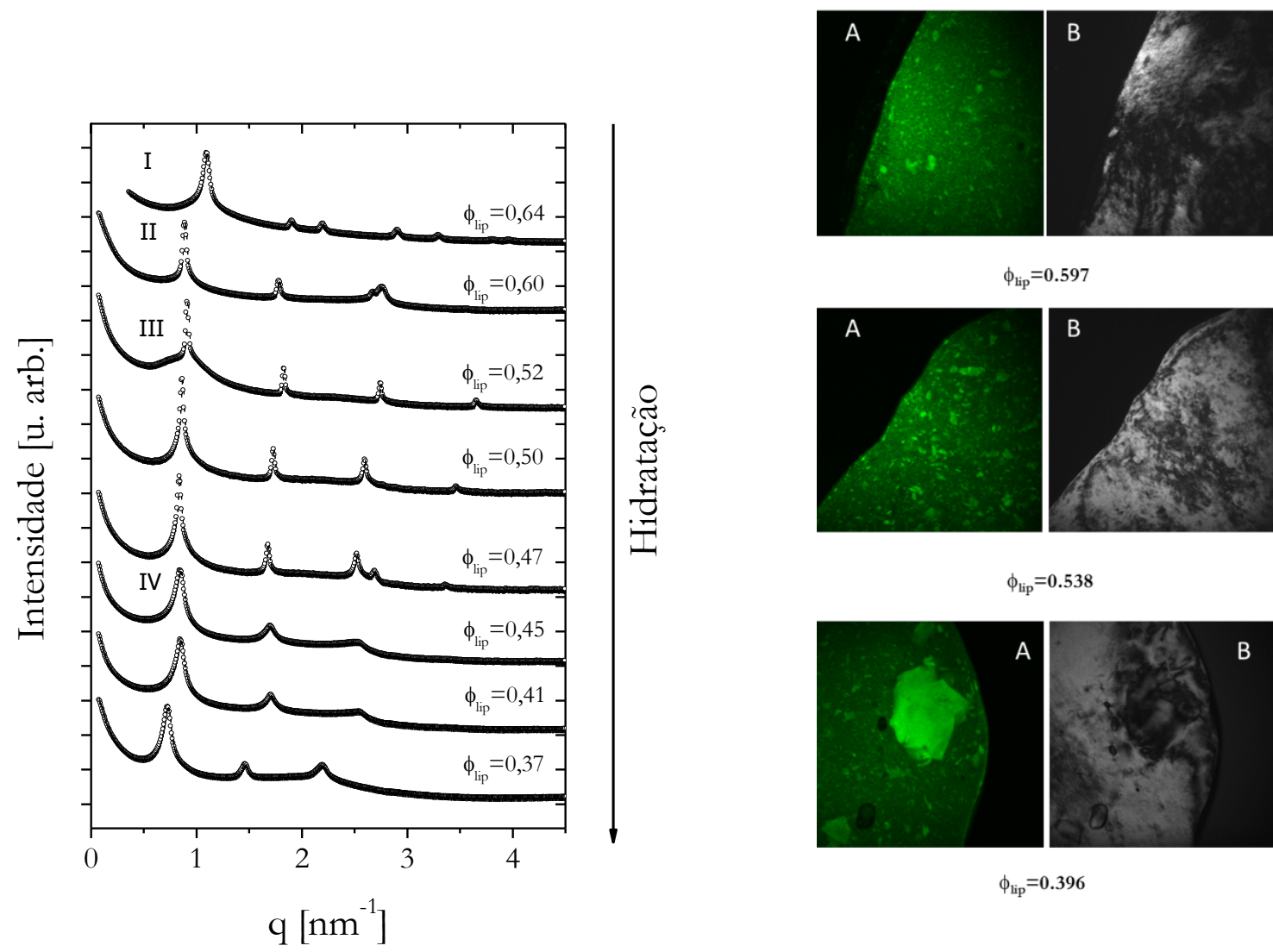

$\phi_{\text {lip }}=0.538$

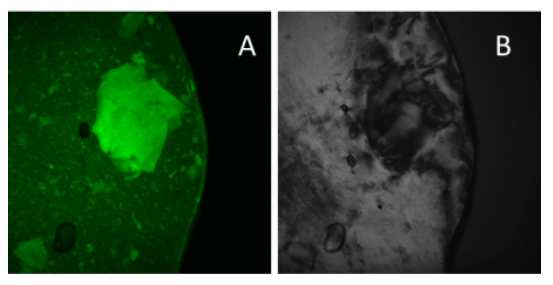

$\phi_{\text {lip }}=0.396$

Figura 0-1 Curvas de espalhamento obtidas para sistemas ternários com sistema lamelar hospedeiro composto por $30 \%$ de lecitina e $70 \%$ de Simulsol ${ }^{\circledR}$. Do lado direito observam-se texturas em microscopia de fluorescência e polarização. A região verde clara indica a presença de fragmentos de DNA. Os algarismos romanos indicam diferentes formas de organização dos fragmentos de DNA na fase lamelar hospedeira (ver discussão no texto).

Nas curvas de espalhamento, em todas as composições é possível identificar a existência de picos que podem ser indexados a uma fase lamelar. Com a mudança de hidratação, no entanto, observam-se mudanças na estrutura supramolecular, associadas à organização dos fragmentos de DNA no interior da fase hospedeira, que são identificadas pelos algarismos romanos na figura Figura 0-1. Esses arranjos já haviam sido identificados em trabalhos anteriores e correspondem a duas formas distintas de organização do DNA intercalado na fase lamelar. Um dos arranjos corresponde à ordem nemática dos bastões de DNA no interior da camada aquosa, ou seja, ordem orientacional intra-camada.

Outros dois arranjos podem estar presentes exibindo, além da ordem orientacional, ordem posicional inter-camada, podendo ser retangular ou hexagonal bidimensional. Os parâmetros estruturais relevantes são a distância entre os bastões de DNA definida pelo parâmetro $a$, e a periodicidade lamelar $D$ (Figura 0-2). No arranjo hexagonal de fragmentos de DNA há um vínculo 
entre $a$ e $D ; a=2 D / \sqrt{3}$. A estrutura retangular centrada é caracterizada pelos parâmetros $a$ e $b$, como mostrado na Figura $0-2$, sendo $b=2 D$. A indexação dos picos para cada uma dessas estruturas está indicada na Tabela $0-1$.

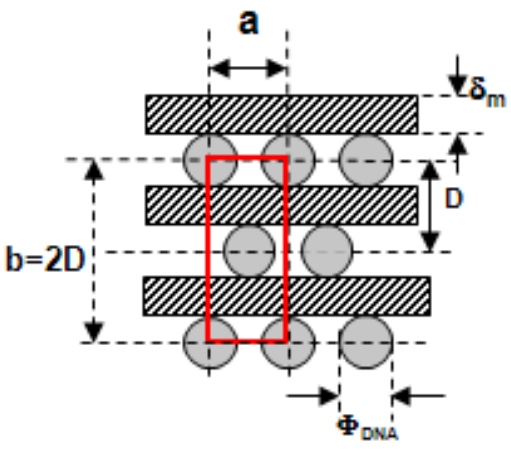

(a)

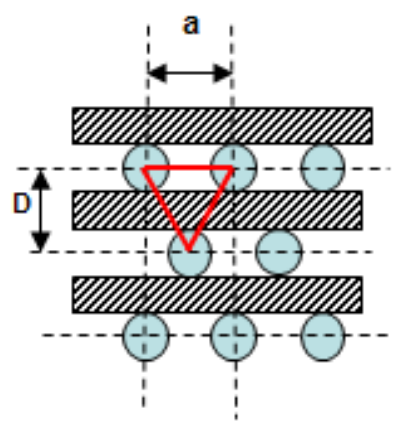

(b)

Figura 0-2 Representações esquemáticas do modelo geométrico de cada célula unitária (da esquerda para a direita: retangular centrada e hexagonal). $\boldsymbol{D}$ é a distância de repetição lamelar, $\boldsymbol{a}$ é a distância entre bastões de DNA dentro de uma mesma camada de água, $\boldsymbol{\Phi}_{\boldsymbol{D N A} \boldsymbol{A}}$ é o diâmetro dos cilindros de DNA e $\delta_{\boldsymbol{m}}$ é a espessura da bicamada lipídica.

Tabela 0-1 Indexação dos picos $\boldsymbol{q}_{\boldsymbol{h} \boldsymbol{k}}$ para as diferentes estruturas observadas para o arranjo de fragmentos de DNA.

\begin{tabular}{lcc}
\hline & & Índices de Miller (h,k) \\
\hline Hexagonal & $q_{h k}=\frac{4 \pi}{a_{h e x}} \times \sqrt{\frac{h^{2}+h k+k^{2}}{3}}$ & $h, k= \pm 1, \pm 2, \ldots$ \\
\hline Retangular centrada & $q_{h k}=2 \pi \times \sqrt{\left(\frac{h}{a_{\text {rect }}}\right)^{2}+\left(\frac{k}{b}\right)^{2}}$ & $h+k=p a r$ \\
\hline
\end{tabular}

Partindo-se do regime concentrado, identifica-se um domínio, caracterizado pelo algarismo I, que corresponde a um arranjo hexagonal 2D dos fragmentos de DNA, como representado na Figura 0-2 b). A medida que a fase lamelar é hidratada pode haver um domínio de coexistência entre um arranjo hexagonal e um arranjo nemático, ou dependendo da composição da membrana, um arranjo retangular centrado.

O arranjo nemático ocorre em um domínio mais diluído e é caracterizado pelo aparecimento de um pico largo entre a segunda e terceira ordem da fase lamelar, como mostrado na Figura 0-3. 
As curvas que apresentam essa característica são identificadas pelo símbolo III, na Figura 0-1, e ocorrem para composições com 0,45 $<\phi_{\text {lip }}<0,55$.

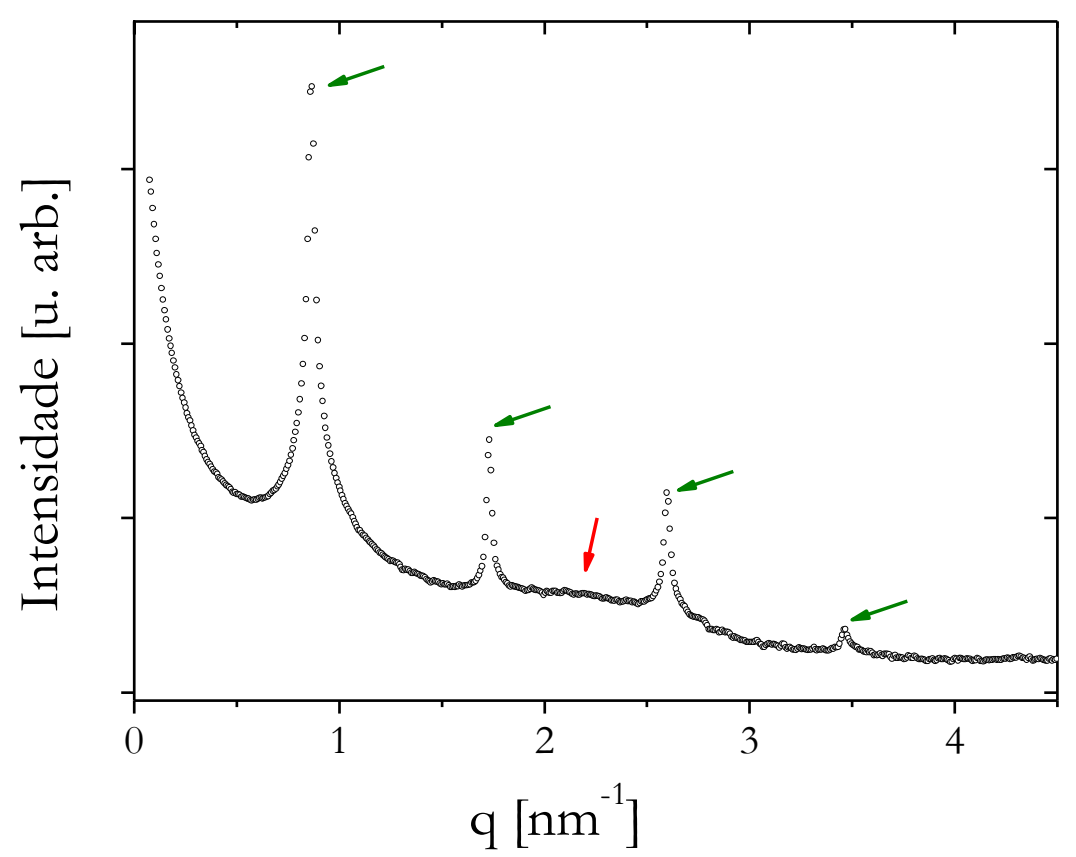

Figura 0-3 Curva $\boldsymbol{I}(\boldsymbol{q}) \times \boldsymbol{q}$ para uma amostra com arranjo nemático dos fragmentos de DNA intercalados na fase lamelar $\left(\phi_{\text {lip }}=\mathbf{0}, \mathbf{4 8}\right)$. As setas verdes indicam os picos que caracterizam a fase lamelar e a seta vermelha indica a presença dos fragmentos de DNA na fase lamelar.

Ao longo do processo de hidratação observa-se ainda uma estrutura lamelar, porem não é possível atribuir um pico a presença de DNA. Como o contraste eletrônico do DNA em relação à bicamada é menor, torna-se difícil a identificação de maneira não ambígua do arranjo dos fragmentos de DNA. Esse domínio pode ser uma coexistência da fase lamelar com DNA em solução, ou ainda DNA intercalado na fase lamelar, mas sem um arranjo ordenado. A Figura 0-4 resume a evolução das estruturas identificadas para as duas composições da fase lamelar investigadas neste estudo, com 10\% de lecitina e com 30\% de lecitina. Para o sistema lamelar composto por apenas $10 \%$ de lecitina, no regime diluído, não foi possível identificar picos que pudessem ser atribuídos à presença de DNA, embora as observações em microscopia mostrem fluorescência homogênea, que indicam a incorporação dos fragmentos de DNA à estrutura lamelar. 


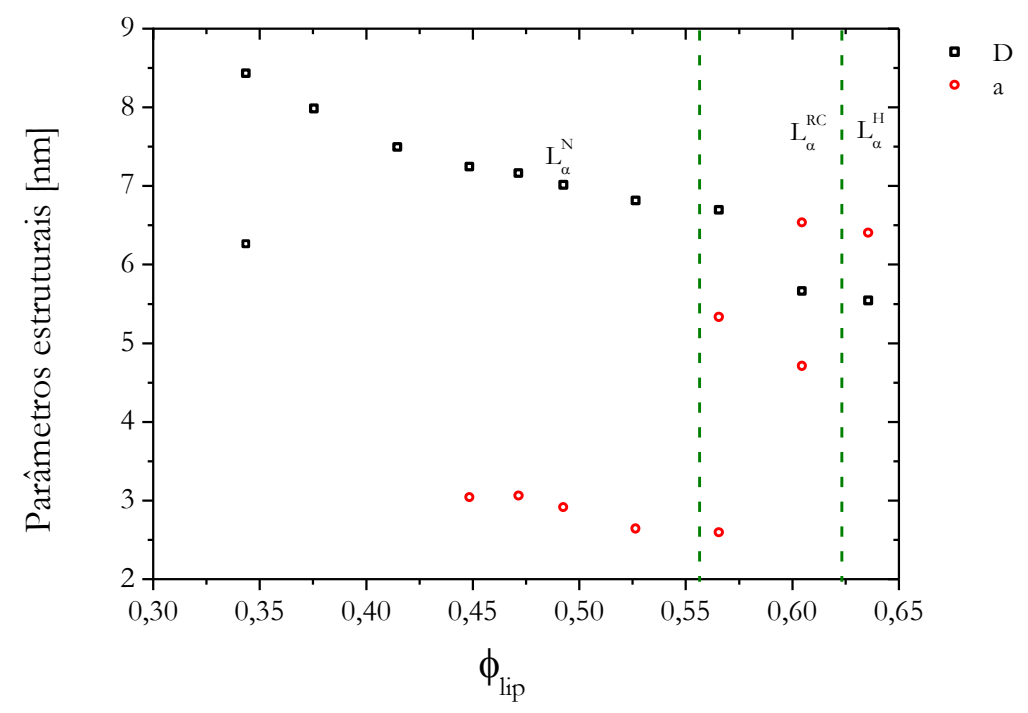

(a)

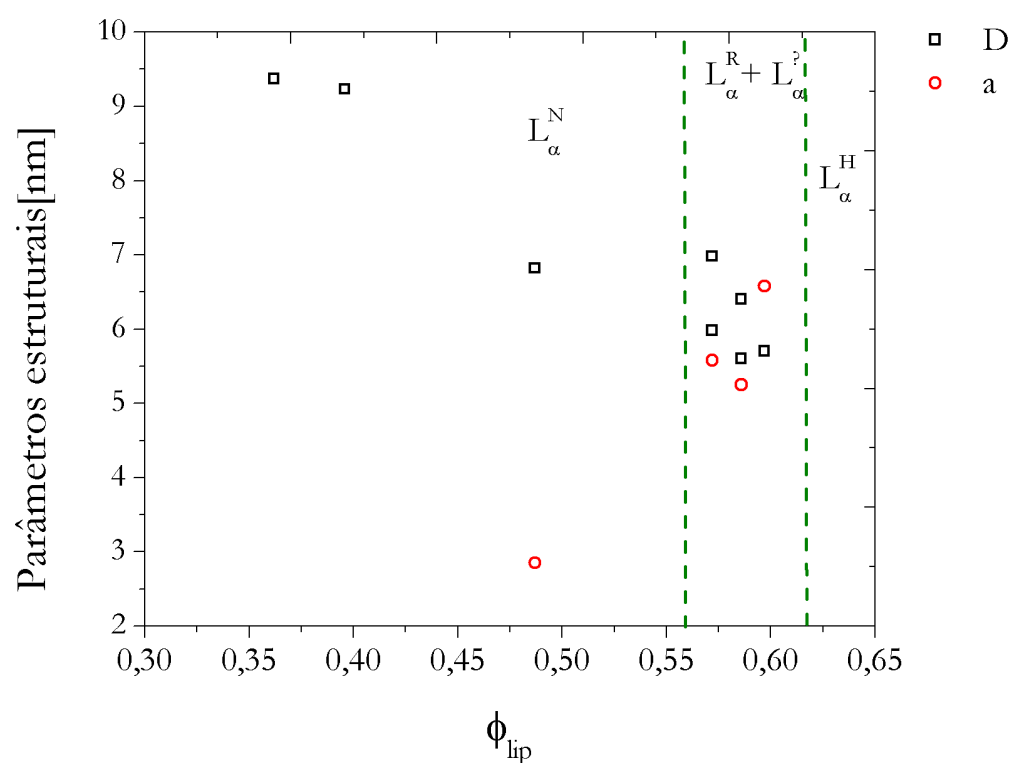

(b)

Figura 0-4: Evolução dos parâmetros estruturais que caracterizam as diferentes estruturas observadas para os complexos de lipídio/DNA com duas composições de membrana distintas; (a) 10\% de lecitina e (b) 30\% de lecitina. Onde os símbolos quadrados representam a periodicidade lamelar e a o parâmetro de ordem dos fragmentos de DNA.

Observou-se para essas duas composições a presença de arranjos nemático e hexagonal, como já havia sido observado para a composição mais rica em lecitina (Silva, 2007; De Oliveira et al., 2010), como mostrado na Figura 0-5. Para a composição com 30\% de lecitina, o domínio de coexistência desaparece e o retangular centrado está presente, em um domínio bastante estreito, 
enquanto o domínio do arranjo nemático torna-se mais extenso. Nota-se também que as mudanças nos parâmetros $D$ e $a$ são mais suaves até atingir o domínio do arranjo hexagonal.

Os valores dos parâmetros da cela unitária $a$ e $D$ possuem valores comparáveis e, no domínio nemático, a distância entre os fragmentos de DNA é da ordem de 3,0 $\mathrm{nm}$ enquanto no domínio do arranjo hexagonal, sob efeito do confinamento, essa distância aumenta para cerca de 6,5 $\mathrm{nm}$. Partindo-se do regime diluído, a mudança no ordenamento dos fragmentos de DNA é acompanhada de uma descontinuidade no valor do período lamelar, que é reduzido de cerca de $1 \mathrm{~nm}$ com a fração volumétrica de lipídio em torno de 0,55.

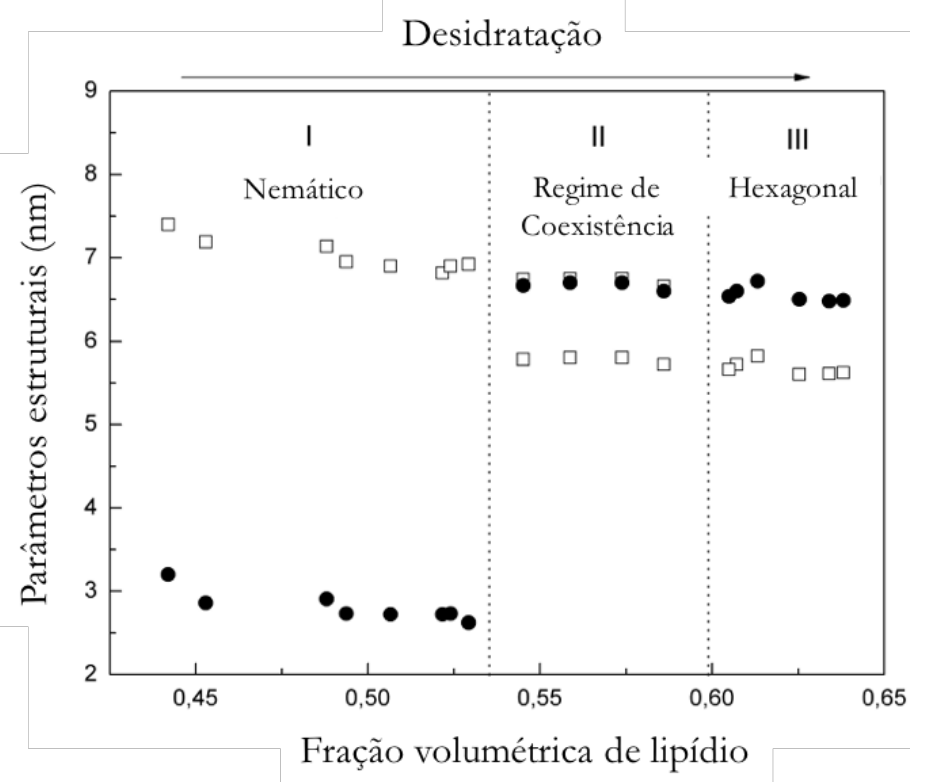

Figura 0-5: Evolução dos parâmetros estruturais que caracterizam as diferentes estruturas observadas para os complexos de lipídio/DNA para membranas contendo 70\% de lecitina. Extraída de (De Oliveira et al., 2010; Da Silva et al., 2011).

Na Figura 0-4 observa-se que o domínio nemático ocorre no regime mais diluído, e a mudança para outra forma de organização, eventualmente com coexistência de fases, ocorre para $\phi_{l i p}=0,55$. Já o domínio hexagonal ocorre no regime concentrado e as mudanças na forma de organização dos fragmentos de DNA ocorrem para e $\phi_{\text {lip }}=0,60$.

É interessante comparar essas informações com o comportamento do parâmetro de Caillé, que caracteriza a flexibilidade da fase lamelar hospedeira. Na Figura 0-6 (a) e Figura 0-6 (b) são apresentados os gráficos que ilustram o comportamento do parâmetro de Caillé para as duas composições de membrana estudadas neste trabalho (Gerbelli, 2012; Gerbelli et al., 2013), onde foram traçadas duas linhas verticais para $\phi_{\text {lip }}=0,55$ e $\phi_{\text {lip }}=0,60$. É possível notar que o parâmetro de Caillé da fase lamelar composta apenas de lecitina apresenta mudança de 
comportamento no mesmo intervalo para o qual ocorrem mudanças no arranjo dos fragmentos de DNA no complexo (Gerbelli et al., 2013; Bougis, 2016)

Para essas duas composições estudadas nesta tese, mais ricas em Simulsol do que a estudada anteriormente, pode-se notar que o domínio do arranjo nemático de DNA é estável em um domínio maior de diluição, estendendo-se no regime diluído. Isso é possível por que para essas duas composições a fase lamelar é estável para grandes distâncias de separação, ou seja, bastante hidratadas.

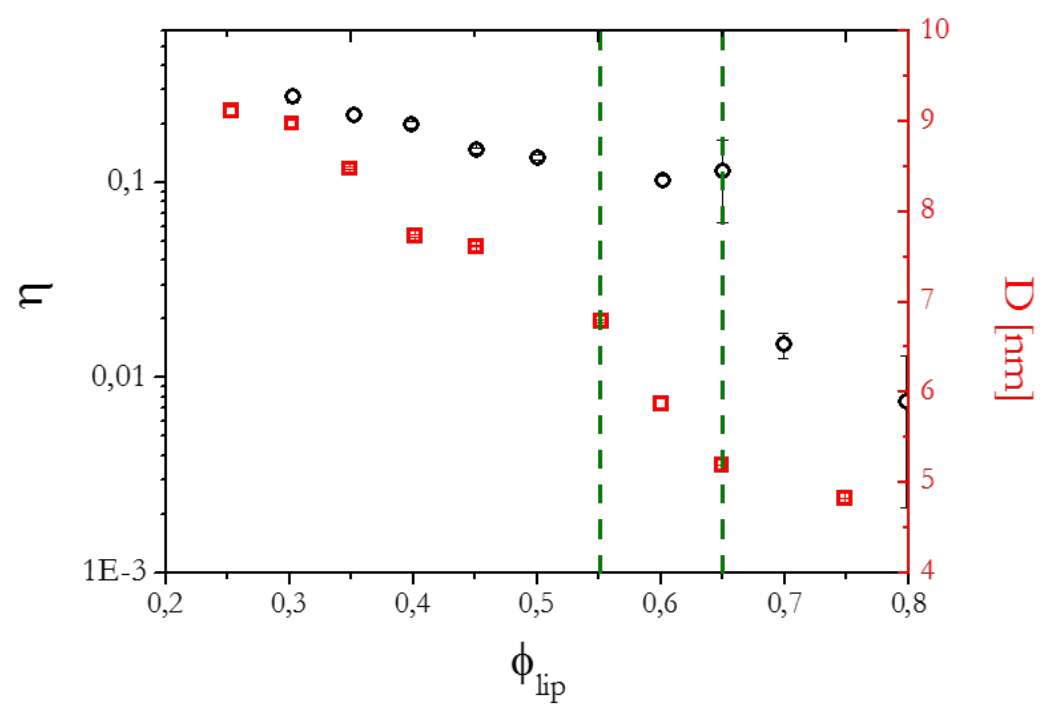

(a)

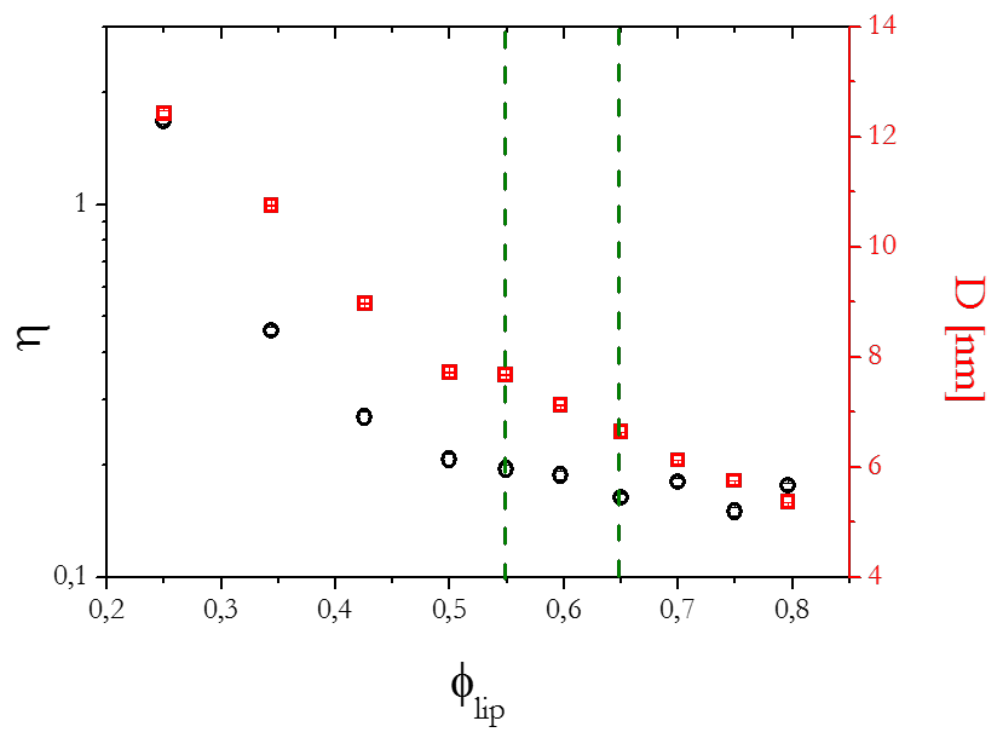

(b)

Figura 0-6: Evolução do parâmetro de Caillé $(\eta)$ e período lamelar $(D)$ das fases lamelares hospedeiras com composições: (a) 30\%, (b) 10\% de Simulsol. Os círculos e os quadrados representam os valores de $\eta$ e $D$, respectivamente. 


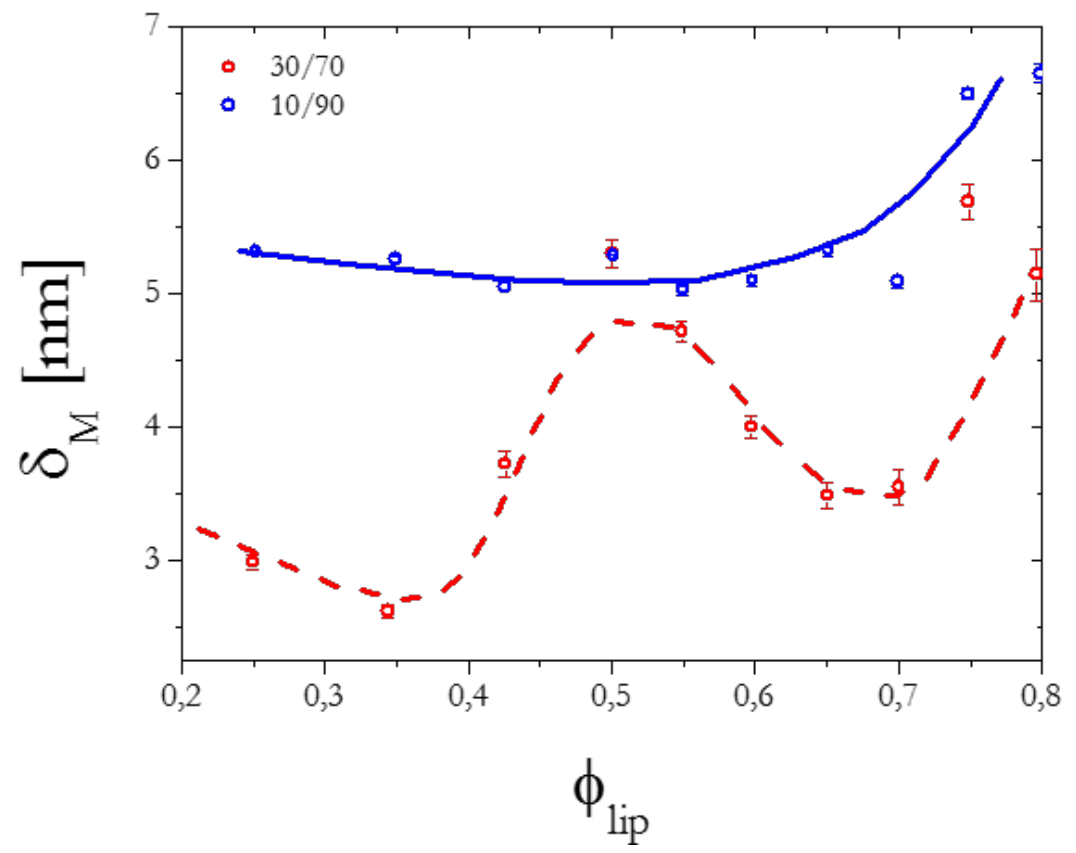

Figura 0-7 Espessura da bicamada obtida a partir do ajuste do perfil de contraste eletrônico para as mesmas composições.

Pode-se supor que a estabilização do arranjo supramolecular esteja ligada à presença das cadeias hidrofílicas do co-surfactante na camada aquosa. Estes podem atuar como "armadilhas" para os fragmentos de DNA, inibindo flutuações de orientação e contribuindo para estabilizar a estrutura lamelar, mesmo em regimes bastante diluídos (Figura 0-8). É importante notar que, para todas as composições, a mudança para o arranjo hexagonal ocorre quando o período lamelar é aproximadamente $6 \mathrm{~nm}$, que é o mesmo valor para o qual observa-se a mudança no comportamento do parâmetro de Caillé. A hidratação e a concentração de co-surfactante atuam como parâmetros que permitem modular as interações entre as em membranas e acessar diferentes tipos de arranjos para os fragmentos de DNA. 


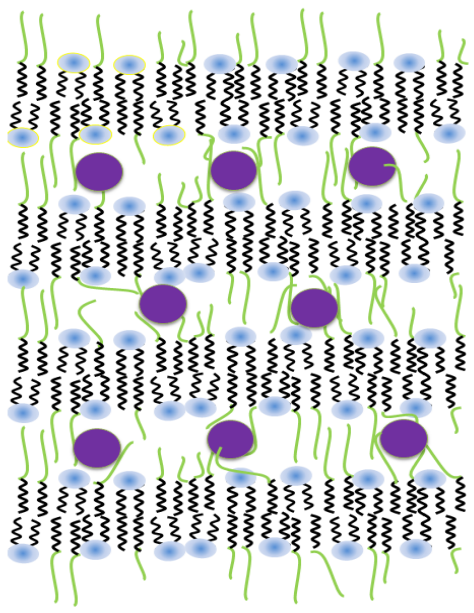

Figura 0-8: Representação esquemática da organização dos fragmentos de DNA entre as bicamadas, de armadilha descrita no texto. 


\section{Discussão}

Houve um grande avanço na compreensão dos mecanismos físicos envolvidos na estabilização da fase lamelar, com o estudo do sistema lamelar hospedeiro (De Oliveira et al., 2010; Da Silva et al., 2011), o que permitiu um melhor entendimento dos processos envolvidos na formação da estrutura supramolecular com DNA tanto para a composição de 70/30 estudada anteriormente, quanto as novas composições.

Foram preparados complexos de lipídios e DNA com os fragmentos de 150 pb, onde variouse a composição da fase lamelar. Essa decisão apoiou-se no fato de já se dispor de resultados qualitativos e quantitativos sobre os mecanismos físicos envolvidos na estabilização da fase lamelar para, então, se compreender como esses mecanismos participam na formação da estrutura supramolecular de lipídios e DNA. Observou-se a formação de diferentes arranjos dos fragmentos de DNA ao longo da linha de diluição, passando de uma estrutura mais organizada (hexagonal) para uma menos organizada (fase nemática). Ao variar a hidratação da estrutura supramolecular verificou-se que é possível estabelecer uma correlação entre os arranjos observados e as propriedades estruturais e elásticas da fase lamelar hospedeira.

O objetivo de se realizar os experimentos com fragmentos mais longos infelizmente não foi atingido. Uma das razões para a decisão de não avançar nessa direção está ligado a um problema técnico. Como foi mostrado no capítulo MATERIAIS E MÉTODOS DE PREPARAÇÃO na seção de Fragmentos de DNA, o processo de sonicação permite a produção de fragmentos maiores, de 1000 a 1500 pb, porém muito polidispersos em tamanho. A preparação dos complexos certamente levaria a coexistência de fases, inviabilizando a obtenção de resultados confiáveis. Uma possibilidade seria utilizar outros métodos de clivagem do DNA, que resultam em um número de pares de base bem definido, como PCR (Ochman et al., 1988), porém a quantidade necessária de DNA para a preparação dos complexos é da ordem de miligramas, o que inviabiliza essa opção do ponto de vista de custo. 


\section{IV.II. Complexos de peptídeos e lipídios}

Nesta seção serão apresentados os resultados do estudo dos complexos formados de peptídeos e lecitina, variando-se a razão molar entre peptídeos e lipídios, P/L. Inicialmente foram realizados experimentos de FTIR, que trazem informações sobre as interações intermoleculares entre os peptídeos e as membranas lipídicas.. Em um segundo momento utilizou-se a técnica de DLS para o sistema em excesso de água para se obter informações tamanho e polidispersidade do sistema. Para o estudo estrutural e elástico do complexo foi utilizada a técnica de SAXS. A fim de se observar o comportamento das cadeias carbônicas e possíveis agregações do peptídeo, utilizouse a técnica de WAXS.

\section{Interação intermolecular dos complexos peptídeos-lipídios}

Para investigar as interações intermoleculares entre os peptídeos FF e CFF nas membranas lipídicas foram realizados experimentos de FTIR variando a razão de peptídeos e lipídios. A fração volumétrica de lipídio nas amostras foi de cerca de 40\%, a fim de atingir proporções de sinal/ruído adequados.

Primeiramente, para fins de comparação, foi observado o comportamento da absorbância apenas da lecitina pura. Para região de 800 a $1800 \mathrm{~cm}^{-1}$ (Figura 0-9) as vibrações associadas carregam informações sobre a interface polar e os grupos fosfatos. Um ponto importante a se destacar é que, tendo em vista que as formulações foram preparadas em $\mathrm{H}_{2} \mathrm{O}$, vibrações na região 1600-1700 $\mathrm{cm}^{-1}$ são mascaradas pela forte absorbância da água neste intervalo. Com isso, a identificação apropriada das ressonâncias ligadas à região amida I dos peptídeos fica prejudicada e, neste caso, foi dado ênfase às vibrações características da lecitina. 


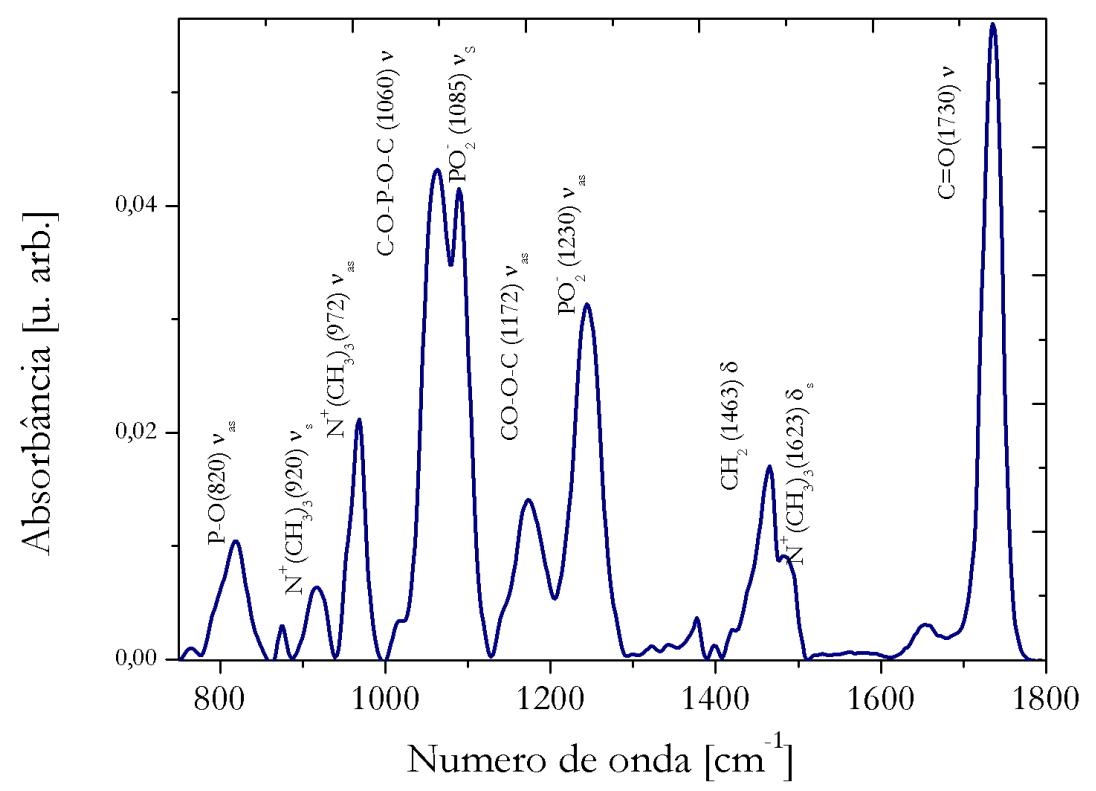

Figura 0-9: Espectro de FTIR da lecitina no intervalo de número de onda 800 a $1800 \mathrm{~cm}^{-1}$.

Ao inserir o peptídeo na membrana, os deslocamentos dos picos e as mudanças de intensidade relativa dos picos são observados na Figura 0-10. Também foram realizados experimentos de FTIR variando razões de P/L com pré-misturas (sem água), e o comportamento dos resultados de FTIR para ambas as preparações foram semelhantes.

Observando o espectro de absorbância do complexo peptídeo-lipídio nota-se que o comportamento vibratório das amostras de $\mathrm{P} / \mathrm{L}$ é altamente complexo, sendo os espectros caracterizados por faixas fortemente misturadas, refletindo a diversidade de grupos químicos disponíveis nas membranas de fosfatidilcolina (Bridelli et al., 2013).

A região compreendida entre 700 e $1800 \mathrm{~cm}^{-1}$ fornece informações sobre as vibrações associadas aos grupos fosfato e colina (Nzai e Proctor, 1999; Lewis e Mcelhaney, 2007), que estão localizados nas proximidades da interface membrana-camada aquosa Figura 0-10.Já o intervalo entre 2800 e $3050 \mathrm{~cm}^{-1}$ contém dados relacionados a vibrações das caudas carbônicas, presentes no núcleo hidrofóbico das bicamadas Figura 0-11 (Popova e Hincha, 2003; Frias et al., 2006). Curiosamente, os picos na região associados às cadeias carbônicas não são afetados pela adição de peptídeos Figura 0-11 sugerindo então que os peptídeos FF e CFF não estão incorporados na parte hidrofóbica das membranas. Por outro lado, os picos relacionados aos grupos químicos da interface mostram variações apreciáveis quando o peptídeo é introduzido na membrana, indicando que as 
interações entre o peptídeo e a membrana lipídica estão fortemente correlacionadas às interações interfaciais.

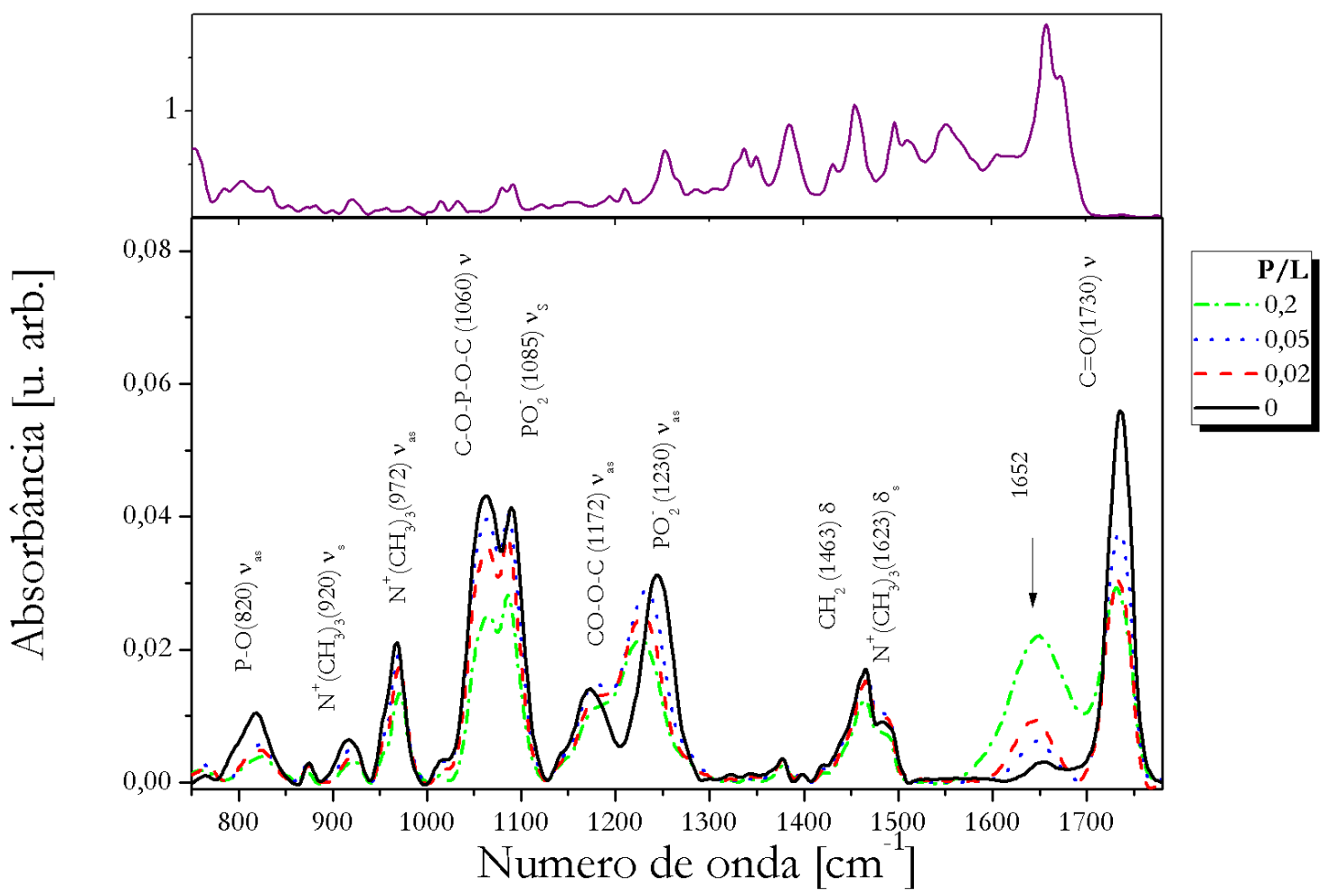

(a)

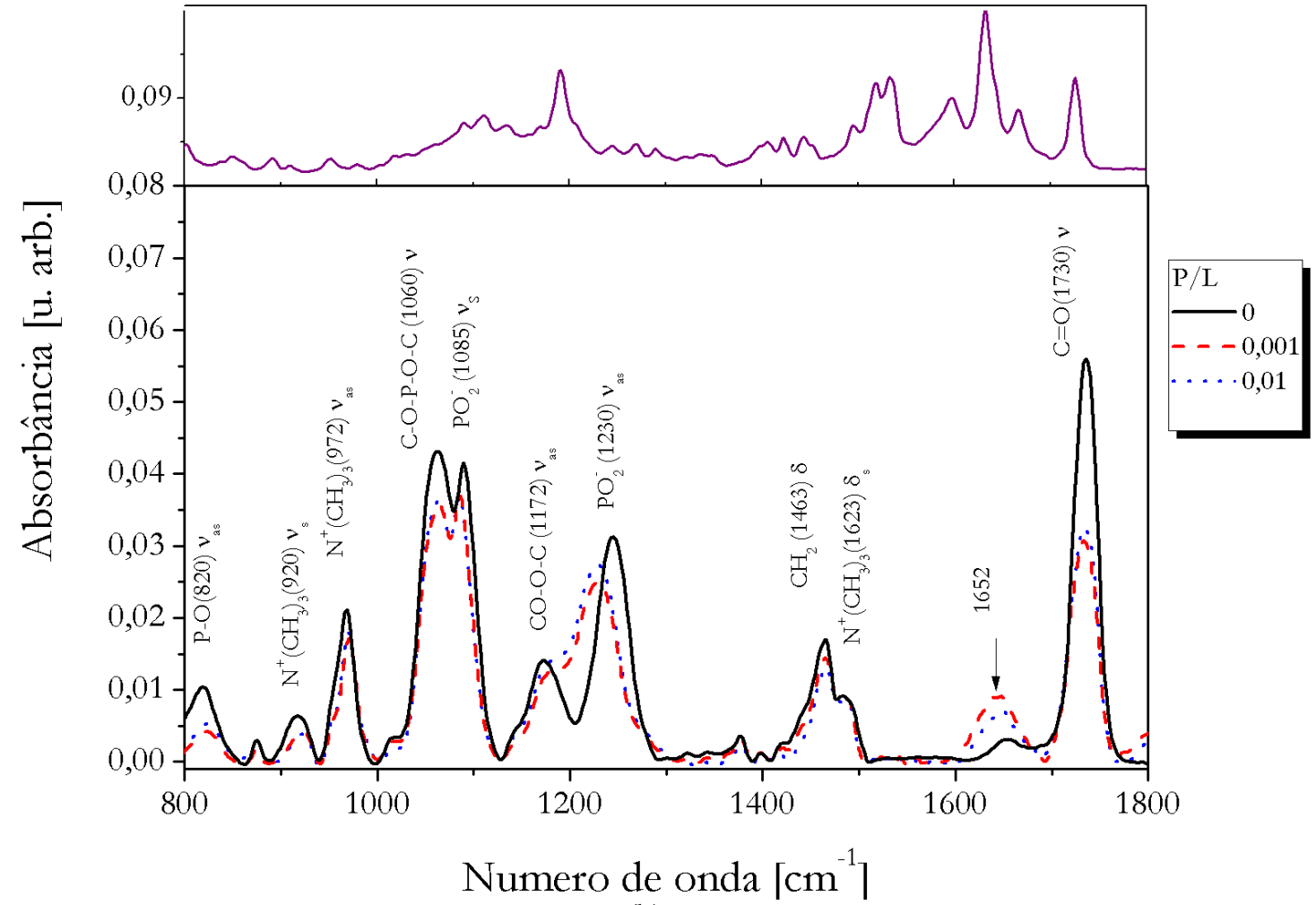

(b)

Figura 0-10: Espectro de FTIR variando-se a razão P/L no intervalo de número de onda de 800 a 1800 $\mathrm{cm}^{-1}$ para os complexos com o peptídeo (a)FF e (b)CFF. Na parte superior dos gráficos as curvas representam o espectro de absorbância dos respectivos peptídeos puros. 


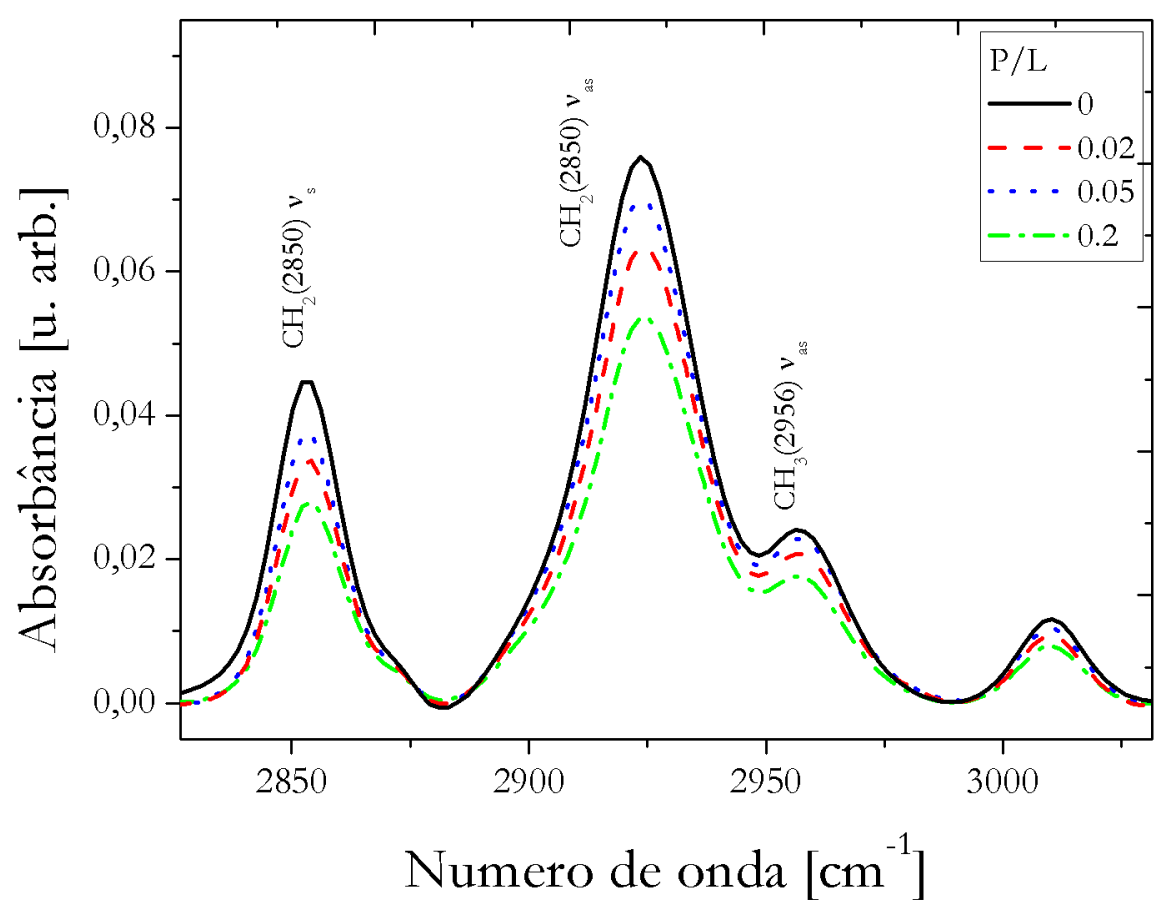

(a)

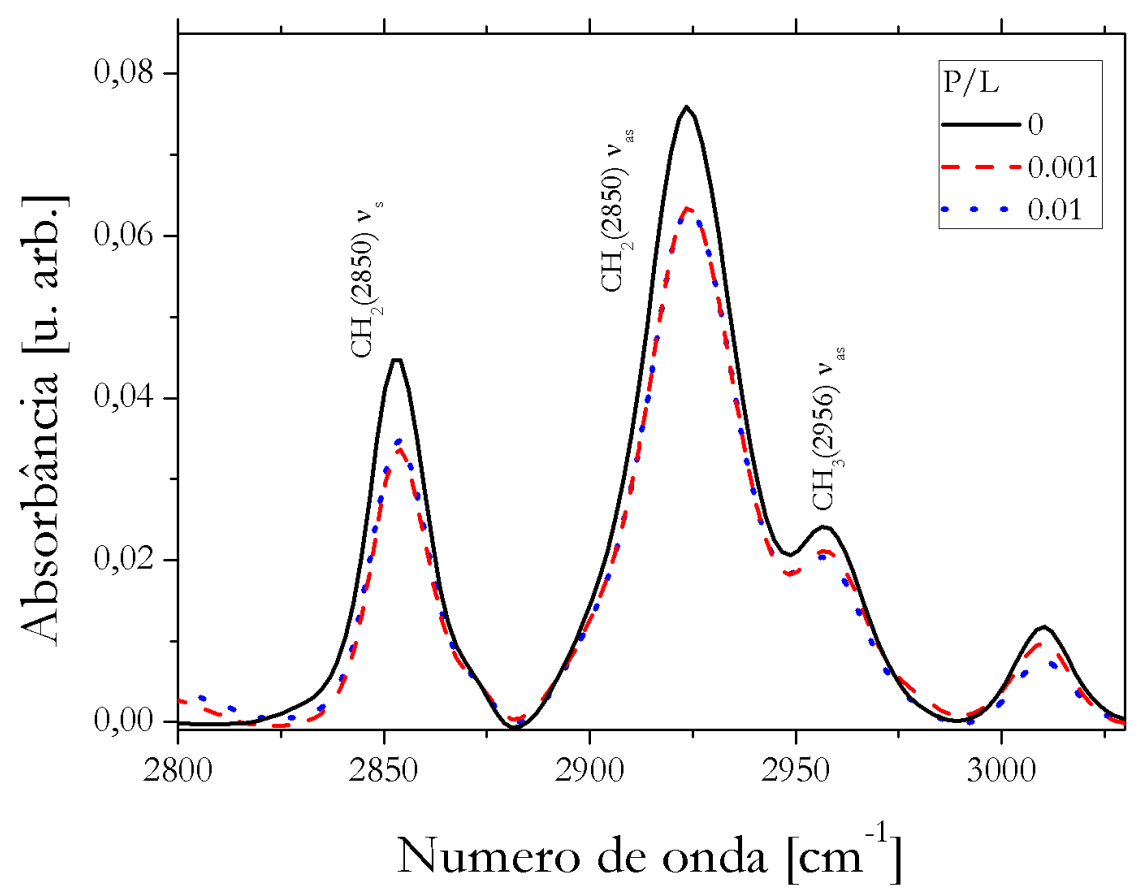

(b)

Figura 0-11: Espectro de FTIR variando a razão P/L no intervalo de número de onda 2800 a $3030 \mathrm{~cm}^{-1}$ para os complexos com o peptídeo (a)FF e (b)CFF. 
$\mathrm{Na}$ Tabela 0-2 é apresentado um resumo das principais vibrações da membrana lipídica afetadas pela presença dos peptídeos.

Tabela 0-2 Resumo das principais vibrações na região dos grupos fosfato e colina. Os valores do número de onda são dados em $\mathrm{cm}^{-1}$. Os grupos químicos associados às vibrações são mostrados na coluna da esquerda.

\section{Lecitina $\quad$ FF/Lecitina $\quad$ CFF/Lecitina}

\begin{tabular}{|c|c|c|c|c|c|c|}
\hline$\underbrace{P / L}_{\text {Vibração }}$ & 0 & 0,02 & 0,05 & 0,2 & 0,001 & 0,01 \\
\hline $\mathbf{P}-\mathrm{O}_{\text {vas }}$ & 819 & 823 & 824 & 824 & 823 & 823 \\
\hline $\mathrm{N}^{+}\left(\mathrm{CH}_{3}\right)_{\mathrm{vs}}$ & 916 & 921 & 923 & 923 & 922 & 923 \\
\hline $\mathrm{N}^{+}\left(\mathrm{CH}_{3}\right)_{3}$ vas & 967 & 969 & 970 & 971 & 970 & 970 \\
\hline C-O-P-O-C ${ }_{v}$ & 1062 & 1064 & 1064 & 1065 & 1063 & 1063 \\
\hline $\mathrm{PO}_{2 \text { vs }}$ & 1090 & 1085 & 1086 & 1085 & 1086 & 1086 \\
\hline $\mathrm{CO}-\mathrm{O}-\mathrm{C}_{\text {vas }}$ & 1172 & 1179 & 1180 & 1179 & 1176 & 1179 \\
\hline $\mathrm{PO}_{2}^{-}$vas & 1244 & 1232 & 1229 & 1226 & 1229 & 1229 \\
\hline $\mathrm{CH}_{2} \delta$ & 1466 & 1466 & 1465 & 1465 & 1466 & 1466 \\
\hline $\mathrm{C}=\mathrm{O}_{\mathrm{v}}$ & 1735 & 1734 & 1732 & 1731 & 1733 & 1733 \\
\hline
\end{tabular}




\section{Discussão}

O intervalo entre 2800 e $3050 \mathrm{~cm}^{-1}$ fornece informações relacionadas a vibrações das cadeias carbônicas presentes no núcleo hidrofóbico das bicamadas (Popova e Hincha, 2003; Bridelli et al., 2013). Curiosamente, as bandas de absorção nessa região não são afetadas pela adição de peptídeo, (Figura 0-10 e Figura 0-11) sugerindo, então, que os peptídeos estudados neste trabalho não estão incorporados na parte hidrofóbica da membrana.

A região compreendida entre 700 e $1800 \mathrm{~cm}^{-1}$ traz informações sobre as vibrações associadas aos grupos fosfato e colina, (Popova e Hincha, 2003; Bridelli et al., 2013) que estão localizados na região da interface da membrana e camada aquosa. As bandas relacionados aos grupos químicos presentes na vizinhança da interface polar apresentam variações apreciáveis quando o peptídeo é introduzido na membrana, evidenciando que a interação peptídeo/lipídio ocorre basicamente na interface. Outra informação importante é que comparando as amostras que contém água com as de pré-misturas, não foram observadas mudanças consideráveis nas variações das vibrações.

Apesar da complexidade do perfil de vibração dificultar a descrição quantitativa, informações valiosas sobre as interações peptídeo/lipídio podem ser obtidas a partir de análises qualitativas observando, por exemplo, os deslocamentos significativos das bandas relacionadas ao grupo fosfato.

As posições de pico das principais vibrações que aparecem nos espectros FTIR são resumidas na Tabela 0-2 acima para as diferentes formulações. Uma vez que nenhuma informação significativa das vibrações das moléculas de água ou espécies de peptídeos estão presentes na região espectral compreendida entre 750 e $900 \mathrm{~cm}^{-1}$, focou-se a atenção nas vibrações desta região em particular. A vibração PO associada ao estiramento assimétrico (P-O $\left.\mathrm{O}_{\text {vas }}\right)$, é fortemente afetada pela adição de peptídeos na matriz lipídica. Na verdade, para a amostra que contém apenas a lecitina, a vibração $\mathrm{P}-\mathrm{O}_{\text {vas }}$ é observada em torno de $819 \mathrm{~cm}^{-1}$. Após a adição de FF, este pico é deslocado para $824 \mathrm{~cm}^{-1}$, indicando crescimento de energia de ligação. No caso de formulações contendo CFF, as mudanças já são observadas quando quantidades muito menores de peptídeos são adicionadas à fase lipídica, sugerindo que a interação entre este peptídeo e a lecitina seja ainda mais forte.

Essas descobertas sugerem um deslocamento de carga das cabeças polares presentes no grupo fosfato na presença do peptídeo. Em particular, há indicações da formação de ligações de hidrogênio entre átomos de oxigênio presentes no grupo fosfato e o peptídeo. No caso da espécie FF, a ligação de hidrogênio provavelmente ocorre entre os átomos oxigênio do fosfato e os terminais de amida (ou carboxila) no esqueleto do peptídeo. Para a sequência CFF, os átomos de 
enxofre nas cadeias laterais de cisteína também podem auxiliar a ligação de hidrogênio, explicando a interação mais forte observada quando este peptídeo é introduzido na formulação.

Outra consequência da presença dos peptídeos na fase lamelar é o alargamento de ressonâncias características associadas as ligações de fosfato. De fato, o alargamento dos picos correlacionados com os grupos $\mathrm{P}-\mathrm{O}_{\text {vas }}\left(820 \mathrm{~cm}^{-1}\right)$ e $\mathrm{PO}_{2}^{-}$vas $\left(1230 \mathrm{~cm}^{-1}\right)$ é claramente observada após a adição do peptídeo (ver Figura 0-10). No caso de $\mathrm{PO}_{2}$ vas, este alargamento induz uma sobreposição com o grupo CO-O-C vas $\left(1172 \mathrm{~cm}^{-1}\right)$. A interpretação apropriada de tal sobreposição é mais complexa, uma vez que esta região também traz informações sobre deformações angulares de moléculas de $\mathrm{H}_{2} \mathrm{O}$. No entanto, tal mudança apreciável sobre a adição de peptídeo não indica apenas que a interação peptídeo/lipídio ocorre principalmente no grupo fosfato, mas também sugere que a solvatação dos peptídeos poderia ser afetada com a presença da água (Vandevondele et al., 2012). Além dos grupos fosfato, também são observadas mudanças nas vibrações associadas aos grupos colina, onde as frequências relacionadas são atribuídas a vibrações de $\mathrm{N}^{+}\left(\mathrm{CH}_{3}\right)_{3}$. Observam-se mudanças no caso do alongamento assimétrico de $916 \mathrm{~cm}^{-1}$ para cerca de $923 \mathrm{~cm}^{-1}$, no caso de alongamento simétrico de $967 \mathrm{~cm}^{-1}$ a cerca de $971 \mathrm{~cm}^{-1}$.

$\mathrm{Na}$ região do número de onda $1652 \mathrm{~cm}^{-1}$ observa-se que ao aumentar a concentração de peptídeo esta banda se torna cada vez mais pronunciada. Esta região pode ser associada à formação de agregados peptídios do tipo random coil. 


\title{
Transição de fase multi-unilamelar promovida por peptídeos curtos
}

\author{
Resultados de DLS e Microscopia Confocal
}

Foram realizados experimentos de espalhamento dinâmico de luz para as soluções de vesículas contendo os peptídeos FF e CFF. As curvas de autocorrelação foram ajustadas utilizando o método dos cumulantes. A partir do ajuste obtém-se a distribuição de tamanhos, apresentada na Figura $0-12$, para vesículas de lecitina e vesículas com membranas cuja razão P/L são iguais 0,1 .

As vesículas compostas apenas por lecitina apresentam uma grande dispersidade de tamanho, com o raio hidrodinâmico $\left(R_{H}\right)$ médio em torno de $350 \mathrm{~nm}$. Com a incorporação dos peptídeos observa-se uma população de vesículas que permanece com dimensão em torno de 350 $\mathrm{nm}$, e uma outra população com $R_{H}, \sim 1100 \mathrm{~nm} \sim 2200 \mathrm{~nm}$, para as sequências FF e CFF, respectivamente, e com menor polidispersidade de tamanho. É possível que o peptídeo não se distribua de forma homogênea entre todas as vesículas o que explicaria a população de vesículas com o mesmo $R_{H}$ da lecitina pura. Para esta razão molar P/L o peptídeo CFF produz vesículas com o dobro de tamanho do que as vesículas da FF.

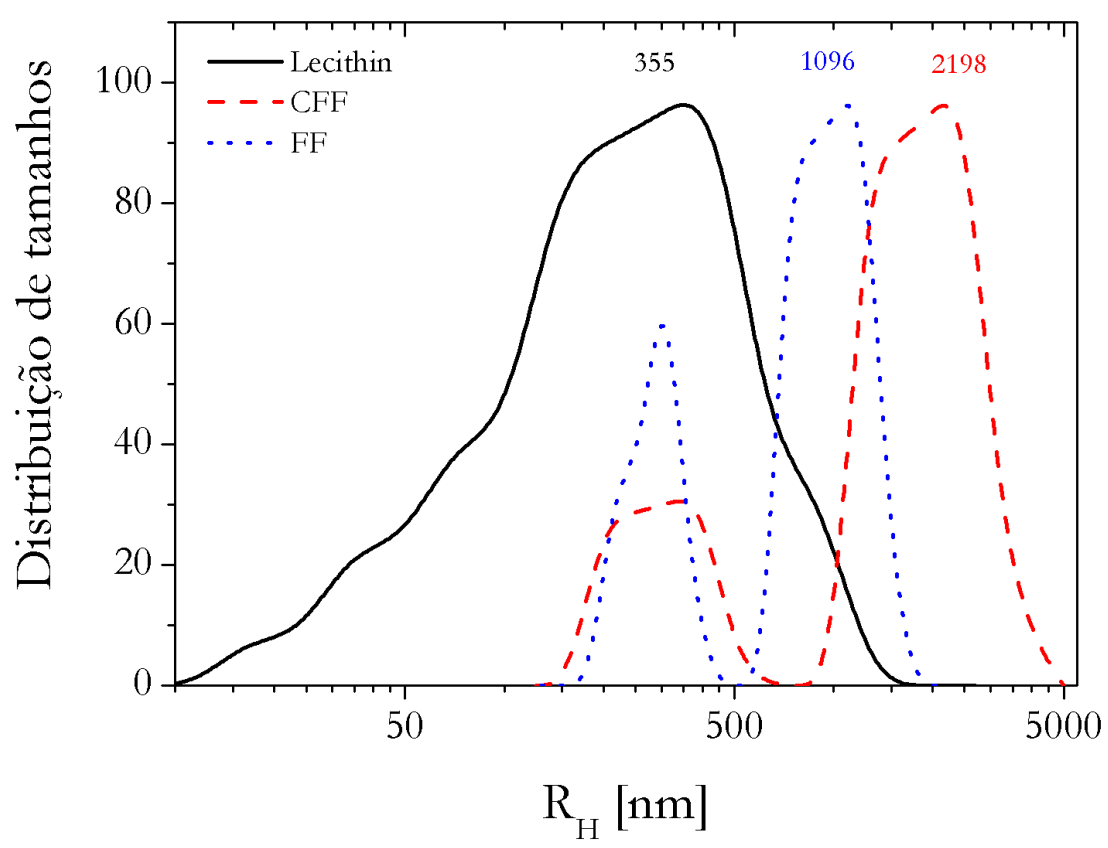

Figura 0-12: Comparação da distribuição de tamanhos versus $\boldsymbol{R}_{\boldsymbol{H}}$ de vesículas compostas de Lecitina e compostas de lecitina-peptídeo na razão $\mathrm{P} / \mathrm{L}=0,1$. 
O aumento da concentração de peptídeo, promove o aumento $R_{H}$ das vesículas, como mostrado na Figura 0-13. Para a sequência mais curta, FF, observa-se que inicialmente a dimensão média das vesículas diminui ligeiramente e aumenta somente quando a razão P/L passa de 0,05 para 0,1. Por outro lado, o aumento da concentração de CFF resulta em um aumento monotônico do diâmetro hidrodinâmico médio das vesículas, atingindo $1500 \mathrm{~nm}$ quando $\mathrm{P} / \mathrm{L}=0,2$.

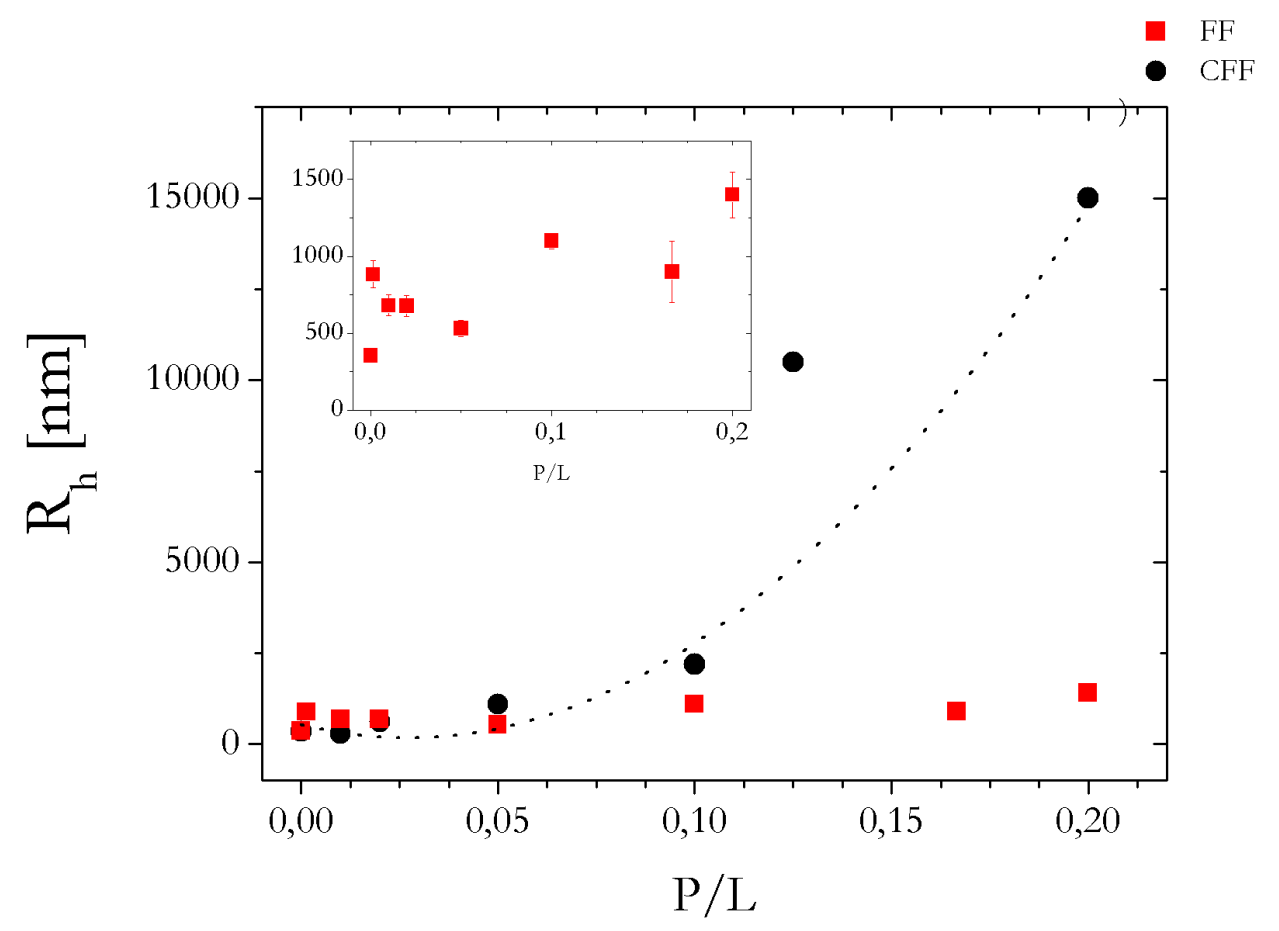

Figura 0-13: Variação do raio hidrodinâmico médio das vesículas variando a razão molar P/L.

Onde os símbolos quadrados representam os resultados do peptídeo FF e os círculos a CFF.

Para grandes concentrações de peptídeos nas amostras $(\mathrm{P} / \mathrm{L}=0,1-0,2)$ as membranas possuem dimensões que permitem a observação direta em microscopia ótica. Na Figura 0-14 são apresentadas as imagens obtidas em microscopia confocal para vesículas contendo FF e CFF, com concentração $\mathrm{P} / \mathrm{L}=0,1$. Na Figura 0-14(a) observa-se a formação de vesículas unilamelares com baixa polidispersidade e diâmetro médio de 6,27 $\mu \mathrm{m}$. Na Figura 0-14(b) para vesículas contendo CFF, é possível identificar duas populações de vesículas unilamelares distintas, uma delas com diâmetro menor que 5,6 $\mu \mathrm{m}$ e uma segunda população com diâmetro médio de 15,9 $\mu \mathrm{m}$.

A partir dos valores de diâmetro determinados pela observação direta, é possível verificar que o diâmetro médio das vesículas contendo CFF é aproximadamente 3 vezes o diâmetro das vesículas contendo FF. Este resultado é consistente com os resultados obtidos nos experimentos de DLS. 

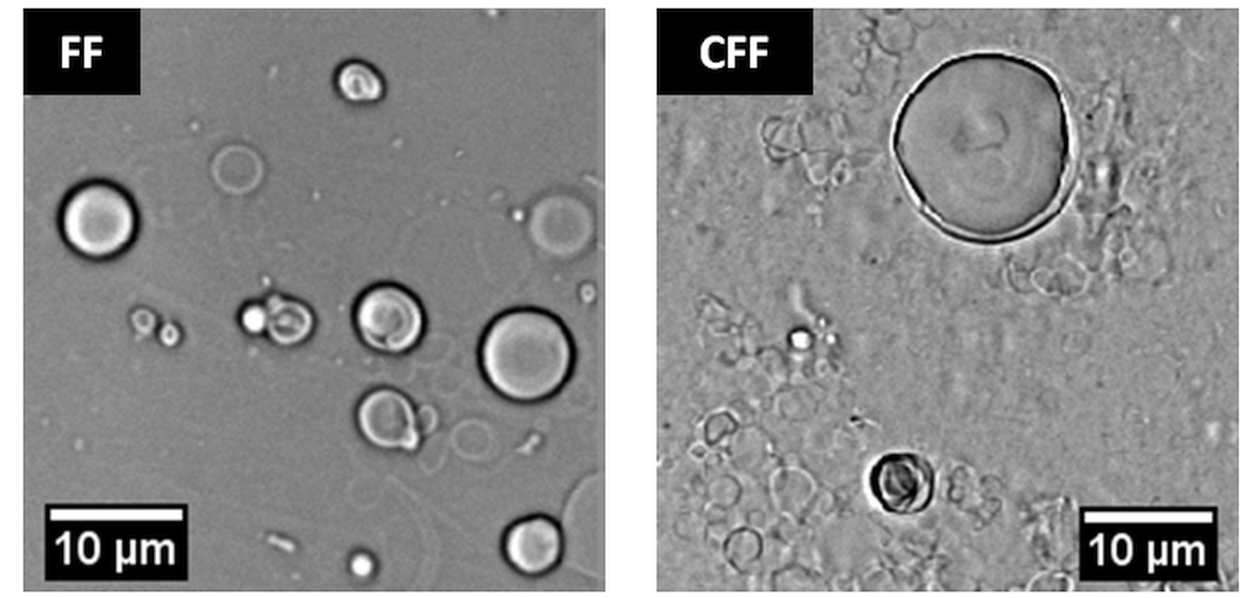

Figura 0-14 Imagens de microscopia confocal para amostras de $\mathrm{P} / \mathrm{L}=0,2$ para os complexos de peptideolipidio. 
Resultados de SAXS

Em um primeiro momento foi estudado o sistema peptídeo-lipídio em excesso de água, promovendo assim a formação de vesículas. Neste experimento, para todos os peptídeos estudados (FF e CFF), a razão $\mathrm{P} / \mathrm{L}$ variou de 0,001 a 0,2 .

Foram realizados experimentos de SAXS para todas as amostras, e o padrão de espalhamento (difratograma) foi registrado em um detector bidimensional (seção Experimentos de $S A X S$ e WAXS). Em algumas imagens foram identificados anéis concêntricos e igualmente espaçados, porém em outras observou-se apenas um anel difuso na região de mais baixo ângulo. Algumas imagens típicas são mostradas na Figura 0-15 para diferentes diluições e para os dois tipos de peptídeos estudados.

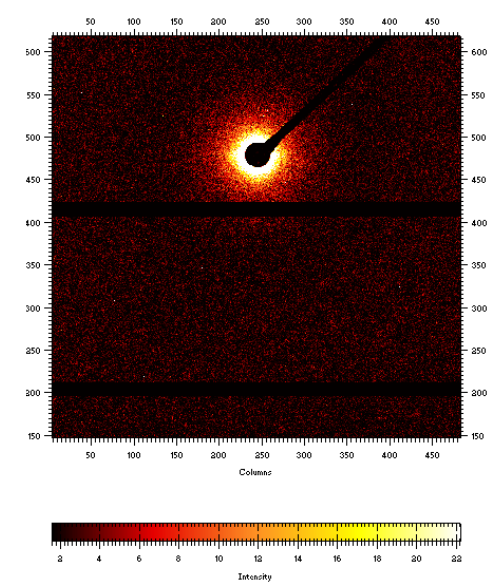

CFF 0,2

(a)

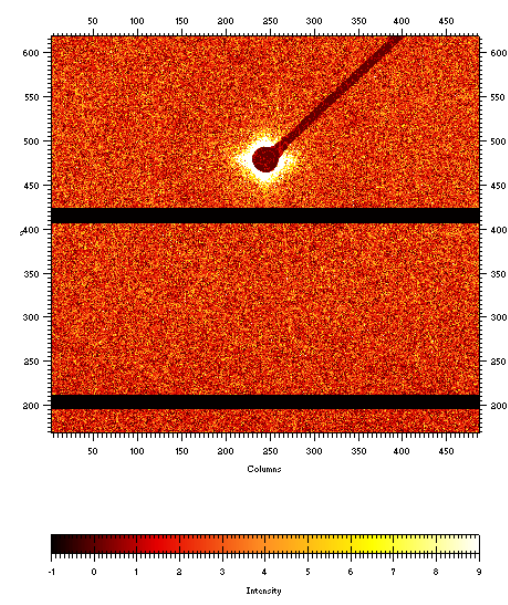

CFF 0,02

(c)

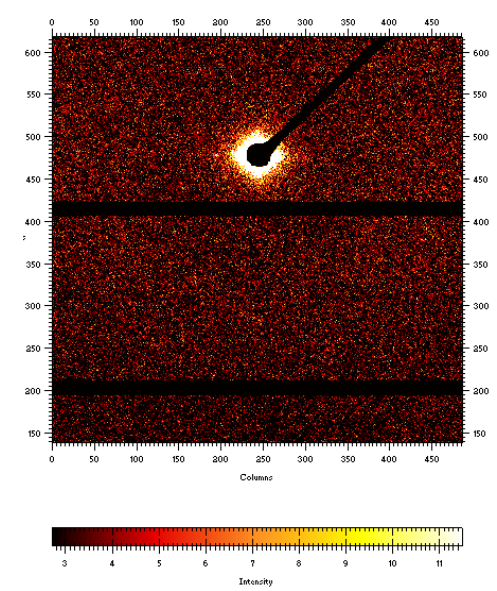

FF 0,2

(b)

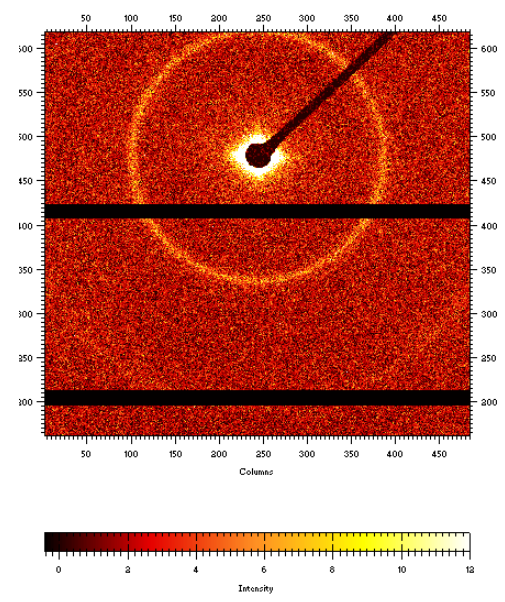

FF 0,02

(d)

Figura 0-15: Difratogramas de fases lamelares compostas de lecitina para os dois peptídeos estudados e para duas razões molares. 
A partir da integração dos difratogramas obtém-se os gráficos $I(q) \times q$, apresentadas na Figura 0-16, variando-se a razão P/L para os peptídeos, FF e CFF. As curvas obtidas para vesículas formadas apenas por lecitina exibem picos de espalhamento característicos de uma fase lamelar, isto é, a razão da posição dos picos segue a proporção 1:2:3..., indicando a presença de vesículas multilamelares. Essa estrutura é preservada quando o peptídeo FF é incorporado à membrana até $\mathrm{P} / \mathrm{L}=0,1$. A periodicidade lamelar para as membranas compostas apenas de lecitina é de $62,5 \AA \mathrm{e}$ aumenta ligeiramente com a incorporação dos peptídeos FF, com valores médios de 64,7 A, e não mostra dependência com a concentração de peptídeo para $\mathrm{P} / \mathrm{L}<0,1$. É interessante observar também que a relação das intensidades do primeiro pico de Bragg com o segundo pico diminui com o aumento da concentração do peptídeo no sistema. Isto é um indicativo da diminuição da ordem da fase lamelar, efeito este que pode ser atribuído a mudanças na forma das bicamadas e/ou mudanças de elasticidade (parâmetro de Caillé) da membrana.

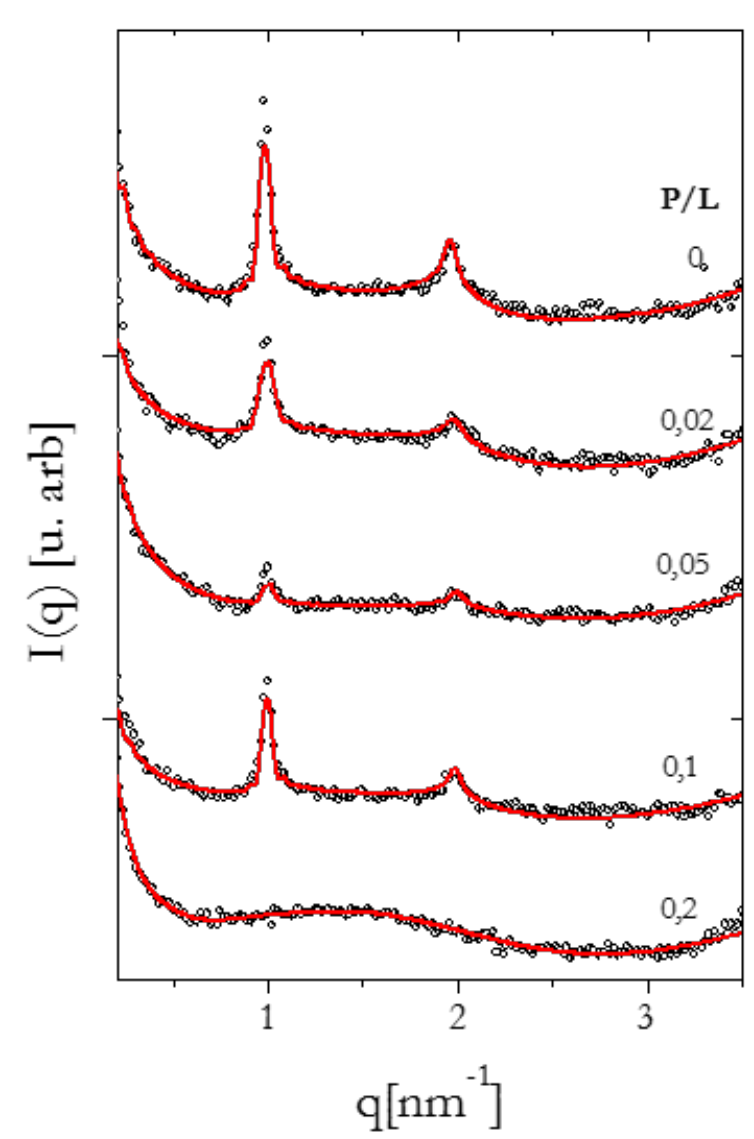

(a)

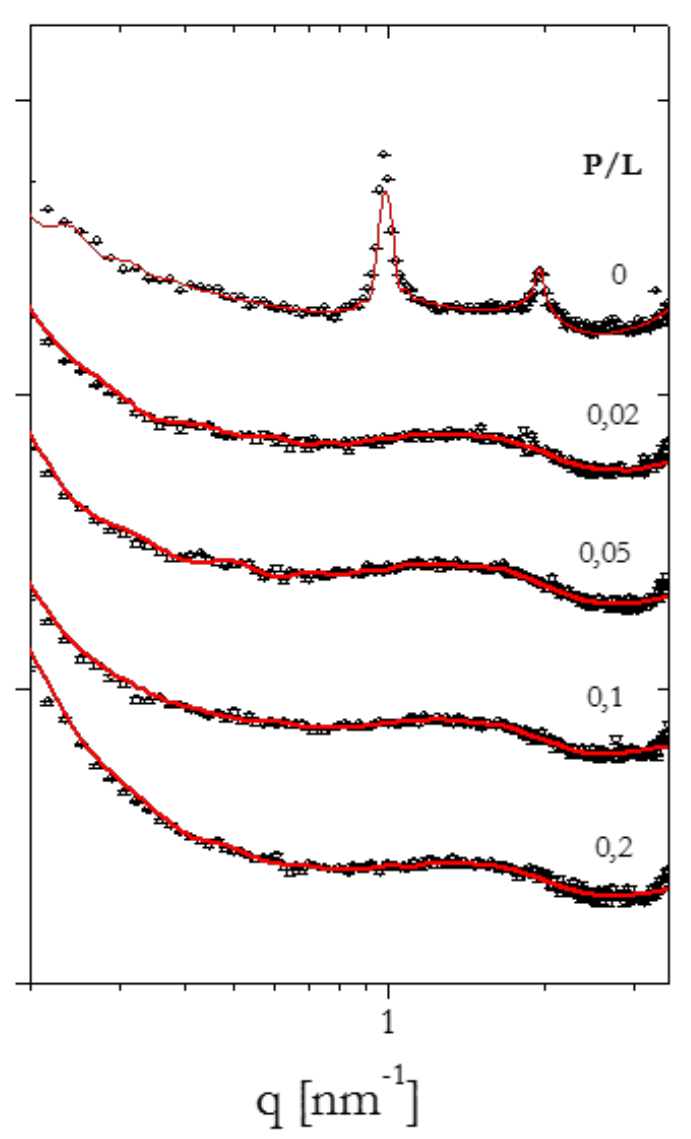

(b)

Figura 0-16: Curvas $\boldsymbol{I}(\boldsymbol{q}) \times \boldsymbol{q}$ para fases lamelares compostas de lecitina e peptídeo com diferentes razões molares de peptídeo e lipídeo. (a) FF e (b) CFF. As linhas contínuas em vermelho correspondem ao ajuste utilizando-se o Método da Deconvolução Gaussiana (seção 
Fator de forma). Os algarismos ao lado das curvas de espalhamento correspondem aos valores de P/L.

Com o aumento da razão $\mathrm{P} / \mathrm{L}$ para 0,2 , os picos de correlação de posição desaparecem e as curvas de espalhamento obtidas exibem apenas um pico largo difuso. Esse mesmo comportamento é observado para as curvas de espalhamento obtidas com a incorporação da sequência CFF, para todas as razões $\mathrm{P} / \mathrm{L}$ investigadas. Como essas curvas são resultado do espalhamento de vesículas unilamelares, a sua análise foi feita utilizando-se a Transformada Inversa de Fourier (IFT), que fornece a função de distribuição de pares de distâncias, $p(r)$ (Figura 0-17). Essa função traz informações no espaço real tanto sobre o contraste de densidade eletrônica quanto sobre o tamanho forma da partícula.

Na Figura 0-17 (a) estão mostradas as curvas $p(r)$ para membranas lipídicas contendo CFF que apresentam uma oscilação na região $0<r<4 \mathrm{~nm}$ (inset Figura 0-17 (b)), característico de sistemas com mudança de contraste de densidade eletrônico interno, tais como micelas e bicamadas. Neste caso particular, trata-se da assinatura do contraste de densidade eletrônica de uma bicamada. O pico positivo da função representa a parte polar da bicamada, com contraste eletrônico positivo em relação ao solvente (água), e ele é seguido de um vale negativo relacionado á parte central hidrofóbica da membrana.

O valor da espessura da bicamada pode ser estimado considerando como referência inicial a abcissa do valor máximo do pico positivo $\left(r_{i}\right)$ e verificando quando este mesmo valor se repete nesta primeira região $\left(r_{f}\right)$, com $\delta_{M}=r_{f}-r_{i}$. Com a adição do peptídeo CFF, observou-se uma diminuição drástica da espessura da membrana de $4 \mathrm{~nm}$ para cerca de $3 \mathrm{~nm}$. Além disso, conforme $\mathrm{P} / \mathrm{L}$ aumenta, o vale negativo posterior ao pico positivo fica cada vez menos negativo até desaparecer completamente para $\mathrm{P} / \mathrm{L}=0,2$. Tal observação indica que este peptídeo em particular promove grandes mudanças na interface da bicamada, provavelmente induzidas pela interação entre a carga residual do resíduo do aminoácido da cisteína e o grupo fosfato.

$\mathrm{Na}$ região correspondente a $r>4 \mathrm{~nm}$, a forma do pico largo indica a presença de partículas relativamente esféricas. Além disso, é possível perceber que o aumento da concentração de peptídeo leva a um aumento da intensidade do pico difuso, o que corresponde ao aumento da quantidade de vesículas na amostra.

Ainda sobre a curva $p(r)$, é possível se ter indicação do tamanho máximo das partículas pela observação do valor da abcissa $r_{\text {máx }}$ para o qual $p\left(r_{\text {máx }}\right)=0$. Ao aumentar a concentração de peptídeo, observa-se que o valor de $r_{\text {máx }}$ aumenta. Como o tamanho das vesículas é maior do que a resolução de tamanho de SAXS, o comportamento $r_{\text {máx }}$ fornece apenas informações 
qualitativas sobre o diâmetro das vesículas. Portanto, pela análise das curvas $p(r)$, observa-se a tendência do aumento do diâmetro das vesículas com o aumento da concentração de peptídeos, informação esta que é corroborada pelas medidas de DLS e microscopia confocal.

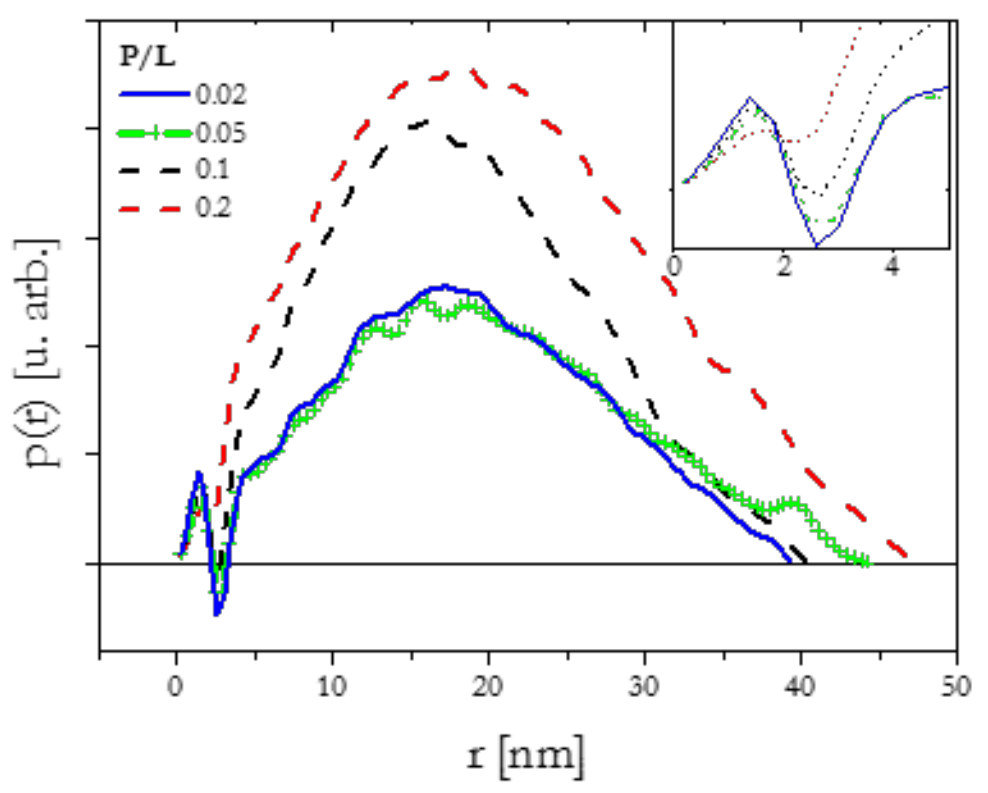

(a)

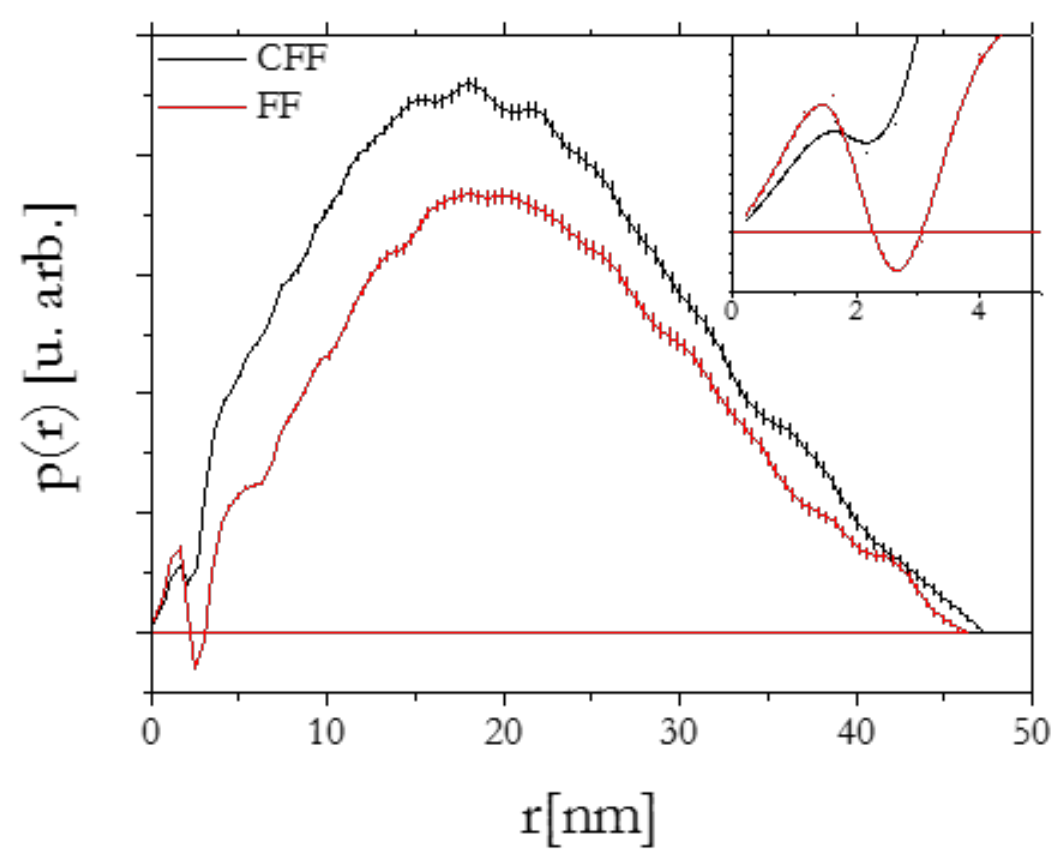

(b)

Figura 0-17: (a) Comportamento da função $\boldsymbol{p}(\boldsymbol{r})$ para a membranas de lipídios contendo CFF com o detalhe da curva na região de $\boldsymbol{r}<5 \mathrm{~nm}$. (b) Comparação entre as funções $\boldsymbol{p}(\boldsymbol{r})$ para as membranas contendo diferentes tipos de peptídeos com $\mathrm{P} / \mathrm{L}=0,2$ com o detalhe das curvas evidenciando mudança no contraste eletrônico na parte hidrofóbica. 
Para as amostras de FF na razão $\mathrm{P} / \mathrm{L}=0,2$, o comportamento da $p(r)$ é semelhante em toda a extensão de $r$. Pela comparação das curvas $p(r)$ para os dois tipos de peptídeos na razão $\mathrm{P} / \mathrm{L}=0,2$ (Figura 0-17 (b)) observa-se que o contraste de densidade eletrônico das vesículas contendo CFF tem comportamento distinto, apresentando um $r_{\text {máx }}$ maior do que as vesículas que contém FF.

As curvas experimentais $I(q)$ que possuem picos de correlação foram ajustadas utilizando o método descrito na seção Fator de estrutura e 
Fator de forma. Esta metodologia de análise fornece parâmetros estruturais, tais como a espessura da bicamada, o contraste eletrônico e o parâmetro de Caillé, que caracteriza a flexibilidade do sistema lamelar (Figura 0-18).

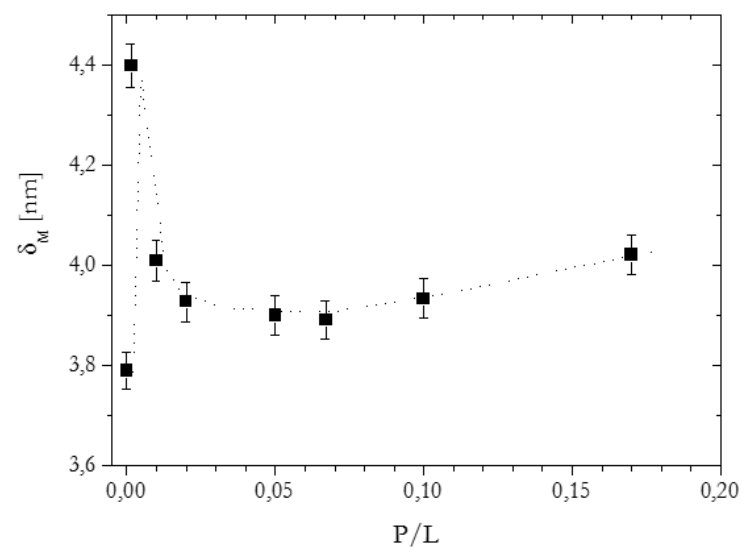

(a)
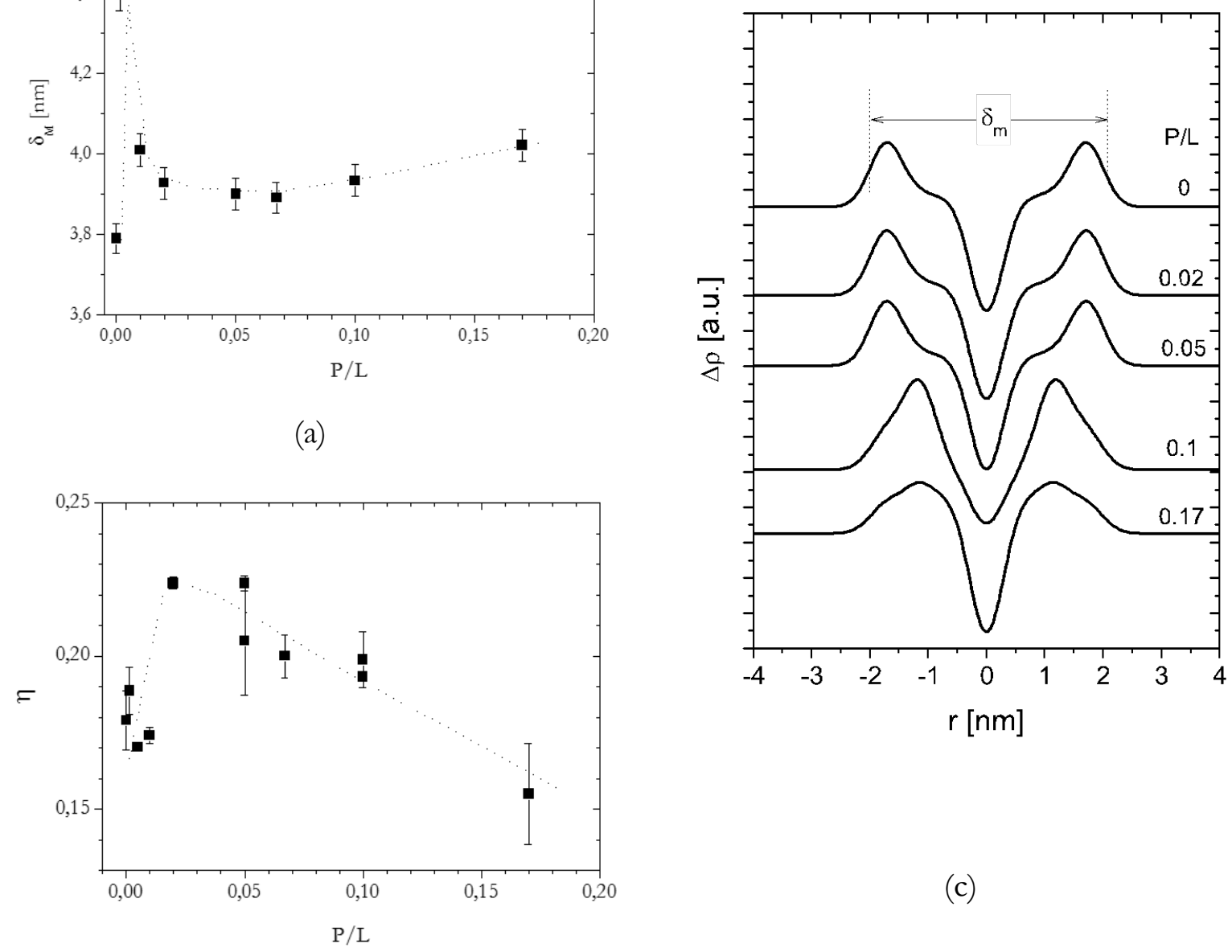

(b)

Figura 0-18 Comportamento dos parâmetros estruturais obtidos a partir do ajuste das curvas de intensidade de espalhamento, com o modelo de 4 gaussianas. (a) Espessura da bicamada. (b) Parâmetro de Caillé. (c) Contraste de densidade eletrônica.

A Figura 0-18 (a) apresenta o comportamento da espessura da bicamada em função da razão $\mathrm{P} / \mathrm{L}$. Ao se inserir o peptídeo na membrana, $\mathrm{P} / \mathrm{L}=0,001$, a espessura da bicamada apresenta uma mudança drástica de 3,8 nm para 4,4 nm. Aumentando ainda mais a concentração de peptídeo, observa-se uma diminuição de $\delta_{M}$ até a razão $\mathrm{P} / \mathrm{L}=0,05$, onde o valor de $\delta_{M}$ é próximo daquele encontrado para o sistema de lecitina pura. Após este valor mínimo a espessura da bicamada volta a aumentar para 4,1 nm com o aumento da razão peptídeo-lipídio. Uma vez que a periodicidade 
lamelar permanece constante, a separação entre as membranas é reduzida com a adição dos peptídeos devido ao aumento da espessura da bicamada.

O comportamento do parâmetro de Caillé é apresentado na Figura 0-18 (b), e observa-se que este é influenciado pela presença do peptídeo. Quando adicionado peptídeo nas vesículas com razão de $\mathrm{P} / \mathrm{L}$ até 0,02 , o parâmetro de Caillé é incrementado de 0,8 , significando que as membranas se tornaram mais flexíveis. Isto pode ser um indicativo de que os peptídeos, em baixas concentrações, conseguem se inserir na superfície da membrana, como mostrado pelos dados de FTIR, criando defeitos locais na membrana. Aumentando-se ainda mais a concentração de peptídeo, o valor de parâmetro de Caillé diminui, assumindo valores até mesmo menores do que aqueles encontrados para o sistema composto apenas por lecitina pura, significando que o sistema se torna mais rígido, quando comparado com o de lecitina pura. É interessante notar que o valor mínimo $\delta_{M}$ é acompanhado pelo valor máximo do parâmetro de Caillé.

Na Figura 0-18 (c) é apresentado o comportamento do perfil do contraste de densidade eletrônica para as amostras de FF. O comportamento de $\Delta \rho$ indica que a ação do peptídeo se dá principalmente na interface da membrana com a camada aquosa, com a mudança na forma dos picos que correspondem a região polar da bicamada, que se torna mais larga e difusa. Este comportamento pode ser atribuído ao fato de que o aumento da quantidade de peptídeos na membrana lipídica desencadeia um aumento da desordem do grupo fosfato, induzido pela autoorganização dos peptídeos.

Para verificar esta hipótese, construiu-se um gráfico de Guinier $\left(\ln I \times q^{2}\right)$, na região de q $\rightarrow$ 0, mostrado na Figura 0-19 (a). A inclinação da reta ajustada aos pontos experimentais no início da curva, é proporcional raio de giro das partículas responsáveis por esse espalhamento. De acordo com essa análise, o aumento da concentração de peptídeos resulta em aumento no raio de giro das partículas na solução, o que pode indicar o aumento do diâmetro das vesículas (assim como observado nos experimentos de DLS e nas imagens de confocal) ou ainda agregação dos peptídeos.

Na Figura 0-19 (b), é apresentada uma curva de espalhamento de uma amostra $\mathrm{P} / \mathrm{L}=0,2$ de FF, com o intervalo de $q$ maior do que os dados apresentados anteriormente (Figura 0-16). Observa-se, além do fator de forma das vesículas unilamelares, um pico em torno de $3,2 \mathrm{~nm}^{-1}$ ( $2 \theta$ $\approx 4,6^{\circ}$ ) que pode ser atribuído à formação da estrutura cristalina do peptídeo FF correspondente à simetria ortorrômbica (Gorbitz, 2006) .

A possível formação de estruturas secundárias dos agregados peptídicos nas amostras foi avaliada por experiências de CD. Os resultados são apresentados na Figura 0-19 (c), e foram comparadas com dados da literatura previamente observados para os nanotubos de FF (AdlerAbramovich et al., 2006; Ryu e Park, 2010) . Nos espectros, é observado um mínimo bem 
pronunciado em $192 \mathrm{~nm}$ seguido de um máximo em 202 nm, este último atribuído a uma transição $\pi \rightarrow \pi^{*}$ e também à formação de $\beta$-folhas, como já identificado na literatura (Gupta et al., 2007; Ryu e Park, 2010). O mínimo observado em $192 \mathrm{~nm}$ pode ser atribuído á formação de agregados de FF desordenados em solução aquosa (Barth, 2007). Isto condiz com o pico em $1652 \mathrm{~cm}^{-1}$ observado no espectro de FTIR, que torna-se mais evidente com o aumento da concentração de peptídeo.

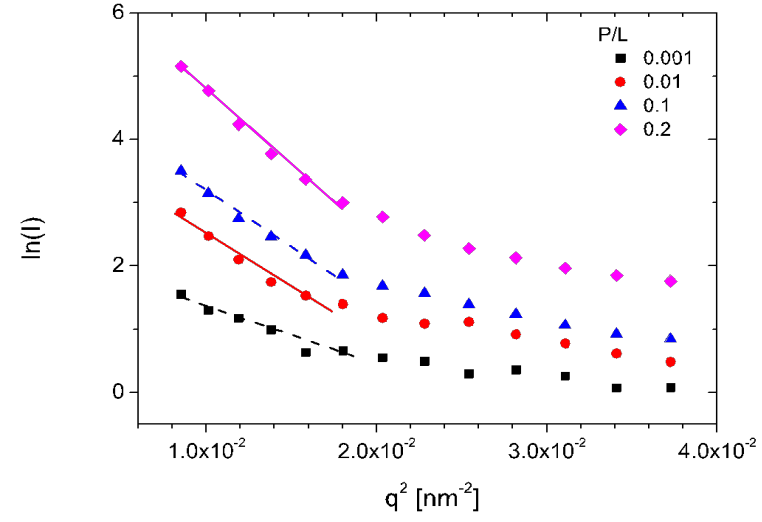

(a)

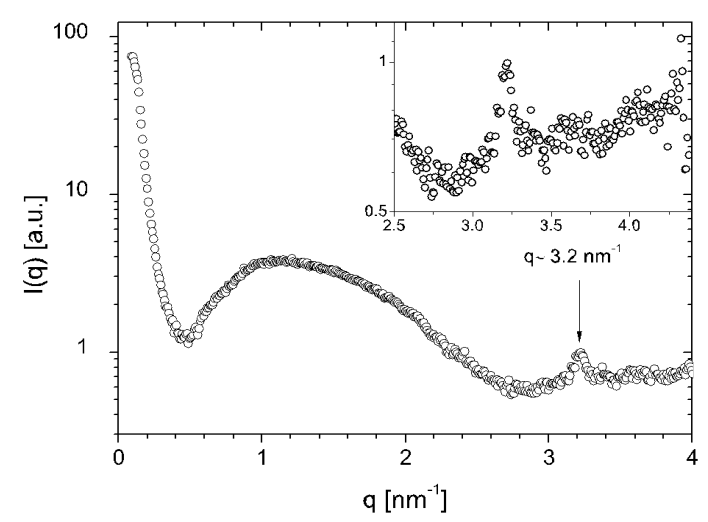

(b)

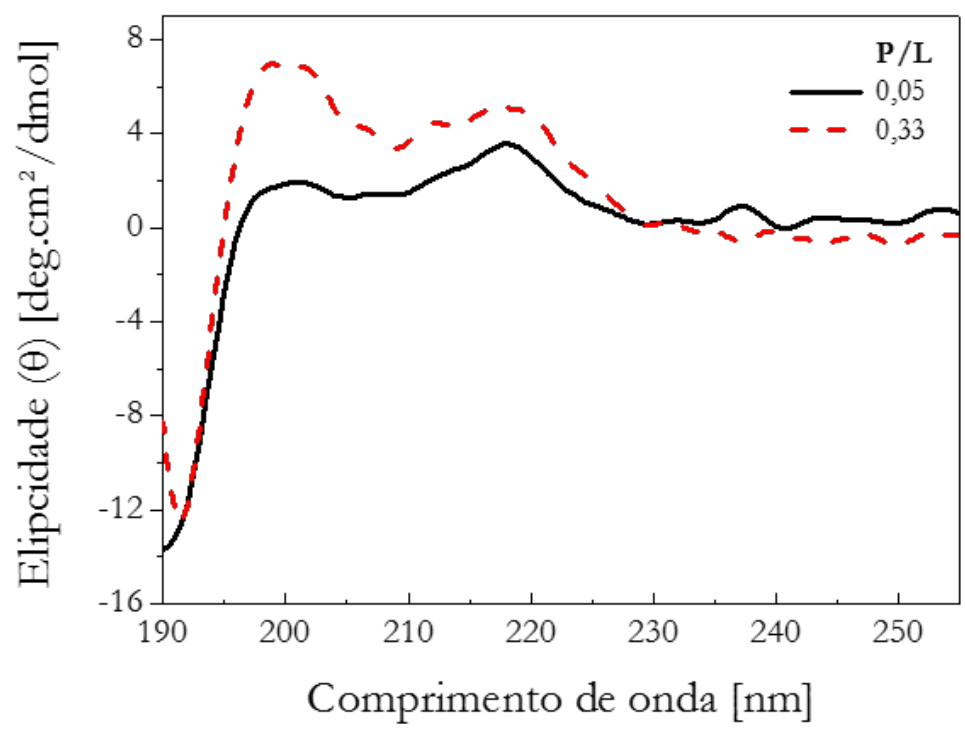

(c)

Figura 0-19(a) Gráfico de $\ln \boldsymbol{I} \times \boldsymbol{q}^{\mathbf{2}}$ na região de Guinier. As linhas pontilhadas são apenas um guia para os olhos. (b) Curva de SAXS para o peptídeo FF na razão $\mathrm{P} / \mathrm{L}=0,2$. Na região de maior ângulo, observouse um pico em torno de $3.2 \mathrm{~nm}^{-1}$ correspondente a estrutura cristalina do peptídeo. Esta região pode ser observada no detalhe da figura (c) Espectros de CD para duas amostras de FF com razões de $\mathrm{P} / \mathrm{L}$ diferentes. 
Um máximo próximo a $218 \mathrm{~nm}$ também é observado no espectro de CD, e está relacionado com as transições eletrônicas dos anéis aromáticos presentes em espécies ricas em fenilalanina (Barth, 2000) . O aumento da intensidade do pico $202 \mathrm{~nm}$ com o aumento da razão P/L sugere a formação de estruturas mais ordenadas à medida que a quantidade de FF aumenta. Além disso, é consistente com o aparecimento de agregados peptídicos que poderiam desencadear a transição multi- unilamelar das vesículas de lecitina e FF (Terzi et al., 1995). 


\section{Discussão}

Os resultados obtidos nos experimentos de DLS mostram que a incorporação dos peptídeos promove o aumento do tamanho das vesículas. Os dados de SAXS para as vesículas contendo FF mostraram que essas vesículas são multilamelares, até a razão $\mathrm{P} / \mathrm{L}=0,1$. Para $\mathrm{P} / \mathrm{L}>0,1$, a ordem lamelar destas vesículas é perdida e surgem as vesículas unilamelares.

Além disso, a diminuição no parâmetro Caillé observada quando os peptídeos são adicionados à membrana pode ser uma consequência da agregação de peptídeos na interface da membrana, o que deve ser acompanhado da diminuição da população de moléculas de água na camada aquosa, de modo a favorecer a auto-organização entre os peptídeos.

Os resultados dos parâmetros apresentados acima sugerem que a ação dos peptídeos na membrana possui comportamento distinto para a razão $\mathrm{P} / \mathrm{L}$ investigada, sugerindo um processo em três etapas. Os dados da SAXS mostram que a espessura da membrana tem um ligeiro crescimento quando pequenas quantidades de peptídeos são incorporadas na fase lipídica. Esse achado é consistente com a tese de que os peptídeos estão inseridos na superfície da membrana e é corroborado com os resultados de FTIR. Este processo é acompanhado de aumento no parâmetro de Caillé, indicando um aumento moderado na flexibilidade da membrana. Essa seria a primeira etapa.

Na segunda etapa, para P/L entre 0,05 e 0,2, o aumento da razão P/L é acompanhada da diminuição do parâmetro Caillé e ligeiro aumento da espessura da membrana, significando que a fase lamelar se tornou mais rígida e o diâmetro da vesícula aumentou. Observa-se também a diminuição das intensidades relativas entre os picos de primeira e segunda ordem nas curvas de espalhamento de SAXS, o que pode ser indicativo da redução no número de bicamadas das vesículas multilamelares.

Finalmente, a terceira etapa, que ocorre para $\mathrm{P} / \mathrm{L}>0,2$, a ação do peptídeo na membrana envolve a formação de estruturas mais complexas dos peptídeos. Estas podem ser responsáveis pelo aumento das interações repulsivas entre bicamadas, que desencadeiam a desestabilização da fase lamelar. A auto-organização dos peptídeos foi demonstrada tanto pelos dados de SAXS quanto pelas experiências de CD.

No caso da sequência CFF, as interações com o grupo fosfato são mais intensas devido à presença das cadeias laterais do aminoácido cisteína. Assim, as mudanças na interface induzidas pela presença deste peptídeo são mais drásticas e mesmo pequenas quantidades desse peptídeo levam à formação de vesículas unilamelares. 


\section{Ação de peptídeos em fases lamelares - Efeito do confinamento -}

Nesta seção serão apresentados os resultados para os complexos FF-lipídio. Variou-se a razão P/L de 0,001 a 0,01. Para cada razão molar P/L foi realizado o estudo da linha de diluição, variando a fração volumétrica de água de 0,2 a 0,8 com o objetivo de estudar o papel do confinamento nas interações entre as bicamadas.

Para determinar qual a mesofase das membranas lipídicas, pode-se utilizar WAXS, que fornece informações sobre as cadeias alifáticas do lipídio. A fase lamelar $L_{\alpha}$ é caracterizada por um pico difuso em torno de $14 \mathrm{~nm}^{-1}$, que representa o estado desordenado das cadeias carbônicas no interior da bicamada. Esse comportamento é observado na Figura IV-20 (a) para uma $\phi_{\text {lip }}=0,80$ e $\mathrm{P} / \mathrm{L}=0,05$. Entretanto, com o aumento da concentração de peptídeos, surgem também pontos de Bragg, e raias mais finas, superpostas ao pico difuso indicando a formação de estruturas cristalinas, como pode ser observado na Figura IV-20(c).
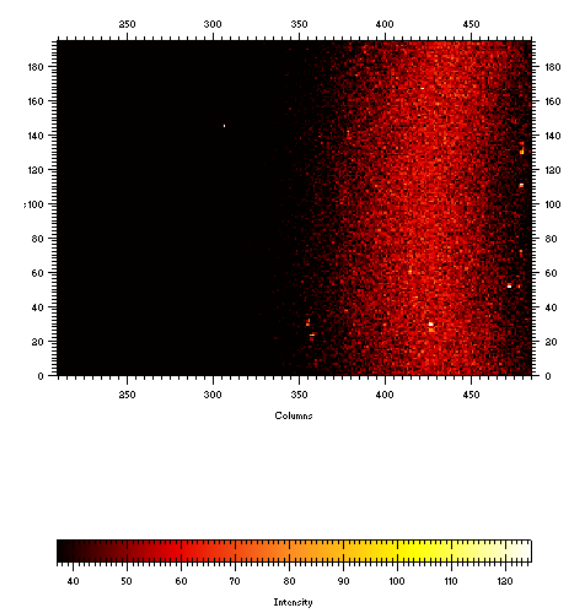

(a)

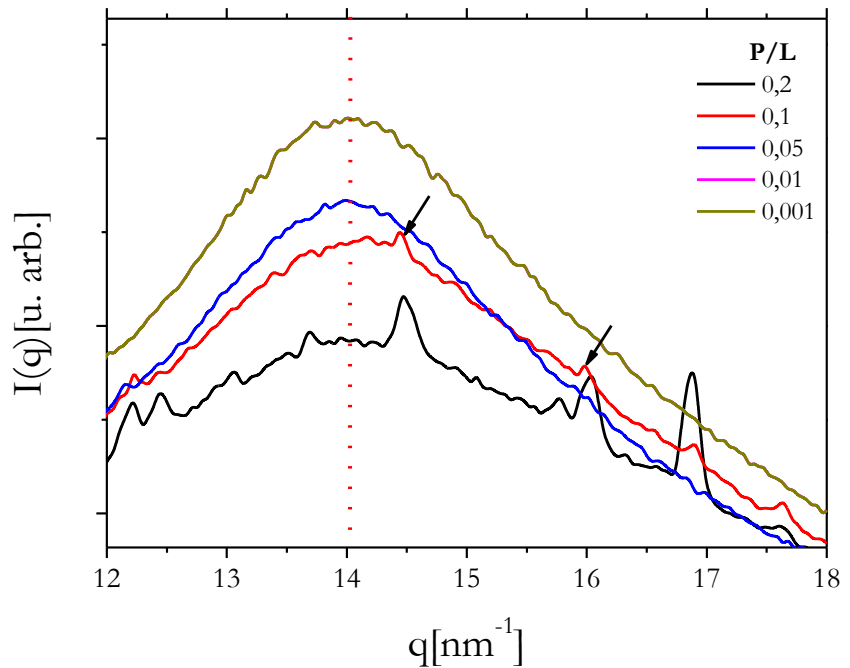

(b) 

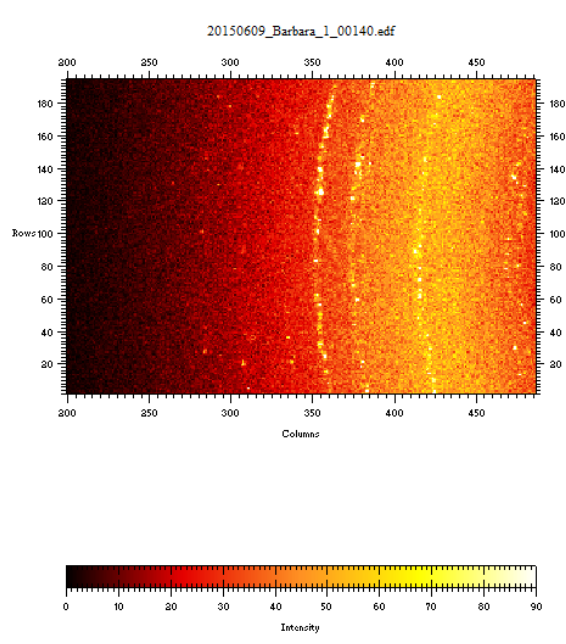

(c)

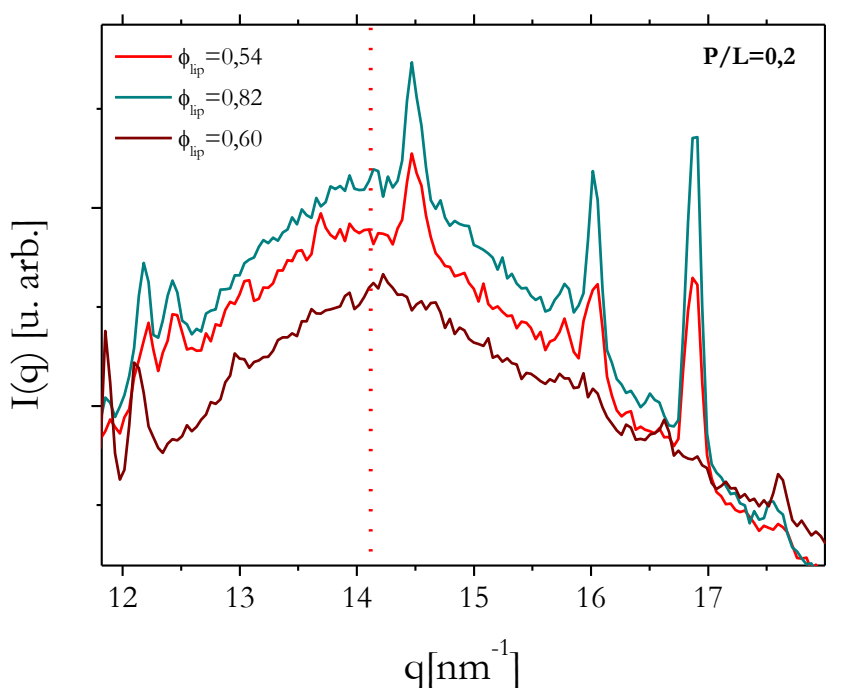

(d)

Figura 0-20: (a) Difratograma de uma amostra contendo FF com razão $\mathrm{P} / \mathrm{L}=0,05$ e $\phi_{\text {lip }}=0,80$ (b) Curvas de I(q) vs. q de WAXS para fases lamelares compostas de peptídeo-lipídio com diferentes razões de P/L. (c) Difratograma de uma amostra contendo FF, com P/L=0,2 e . (d) Curvas de $\mathrm{I}$ (q) vs. q para a razão molar de $\mathrm{P} / \mathrm{L}=0,2$ variando a fração volumétrica de água.

Na Figura IV-20 (b) e (d) são apresentadas curvas $I(q) \times q$ para diferentes razões de $\mathrm{P} / \mathrm{L}$ com $\phi_{\text {lip }}=0,2$ (fixo). Em todas as curvas observa-se um pico difuso com máximo em torno de $14 \mathrm{~nm}^{-1}$, indicando então que a estrutura fluida da membrana é preservada, mesmo com a presença dos picos mais finos, que indicam a formação de estruturas cristalinas, devido a auto associação dos peptídeos.

Esses picos podem ser comparados com resultados existentes na literatura, que investigam a formação de estruturas organizadas em soluções de FF em água. Na Figura 0-21 são apresentadas curvas experimentais de difração de raios-X para a di-fenilalanina em duas condições de temperatura. A curva em verde refere-se ao crescimento do cristal a temperatura ambiente, na qual observou-se a formação de uma estrutura hexagonal, enquanto para a curva em azul o crescimento foi feito acima de $100^{\circ} \mathrm{C}$, o que gerou uma estrutura do tipo ortorrômbica (Heredia $e t$ al., 2010).

Comparando os valores dos picos de difração para as duas estruturas observadas (Heredia et al., 2010) com aqueles encontrados para o sistema FF-lipídio da Figura IV-20 (d), conclui-se que a estrutura da FF presente na fase lamelar é a ortorrômbica. Alguns picos de difração observados no sistema FF-lipídio podem ser identificados com a simetria ortorrômbica, e estão assinalados com asterisco na Figura 0-21. 


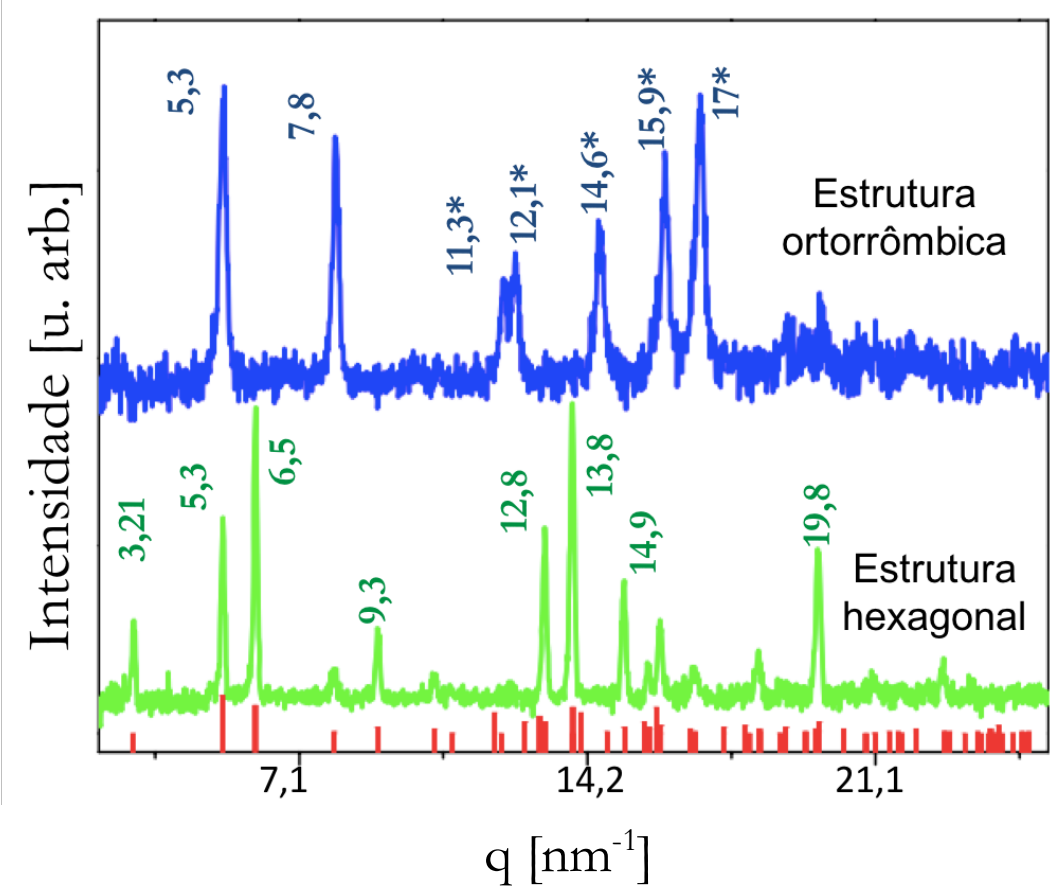

Figura 0-21 Curvas de difração de raios-X para cristais de FF para duas simetrias diferentes. A curva superior apresenta picos de difração correspondentes à estrutura ortorrômbica e a curva inferior uma estrutura hexagonal. Os picos assinalados com asterisco foram observados nos experimentos de WAXS para o sistema FF-lipídio (Figura IV-20 (b) e (d)) . Adaptado de referência (Heredia et al., 2010).

Para as curvas de SAXS (Figura 0-22) observou-se picos de Bragg na razão q: 1:2:3 para todas as composições de $\mathrm{P} / \mathrm{L}$ e hidratação estudadas. Observou-se também um pico com menor intensidade posicionado em $0,10<\mathrm{q}<0,12 \mathrm{~nm}^{-1}$ para razões de $\mathrm{P} / \mathrm{L}$ com $\phi_{\text {lip }}>0,7$. 


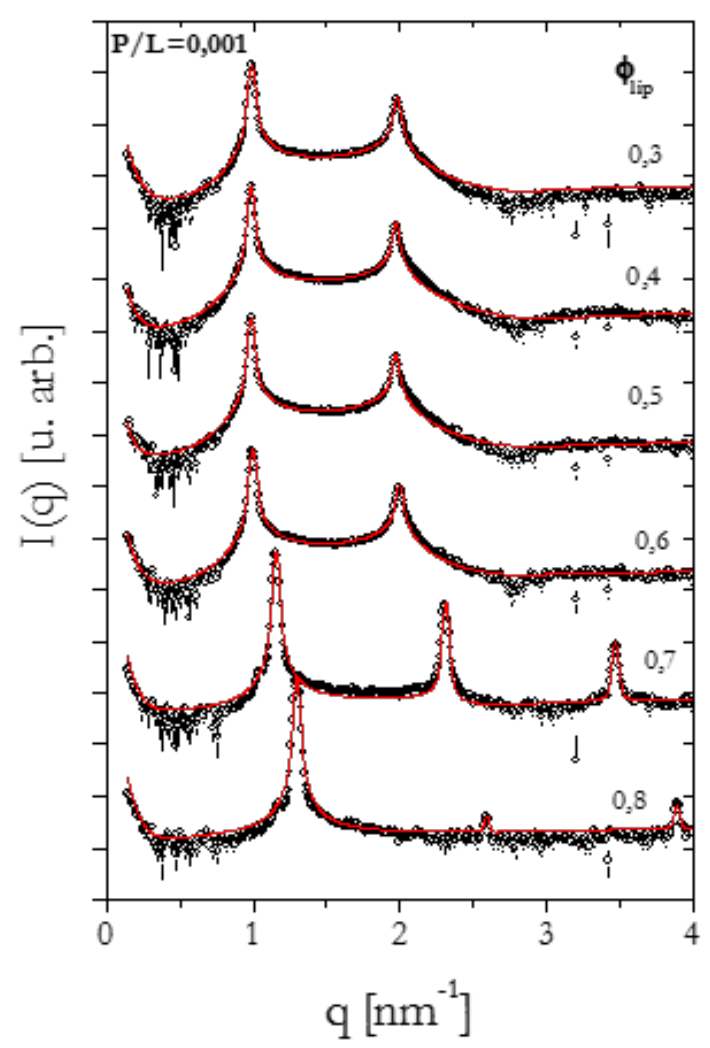

(a)

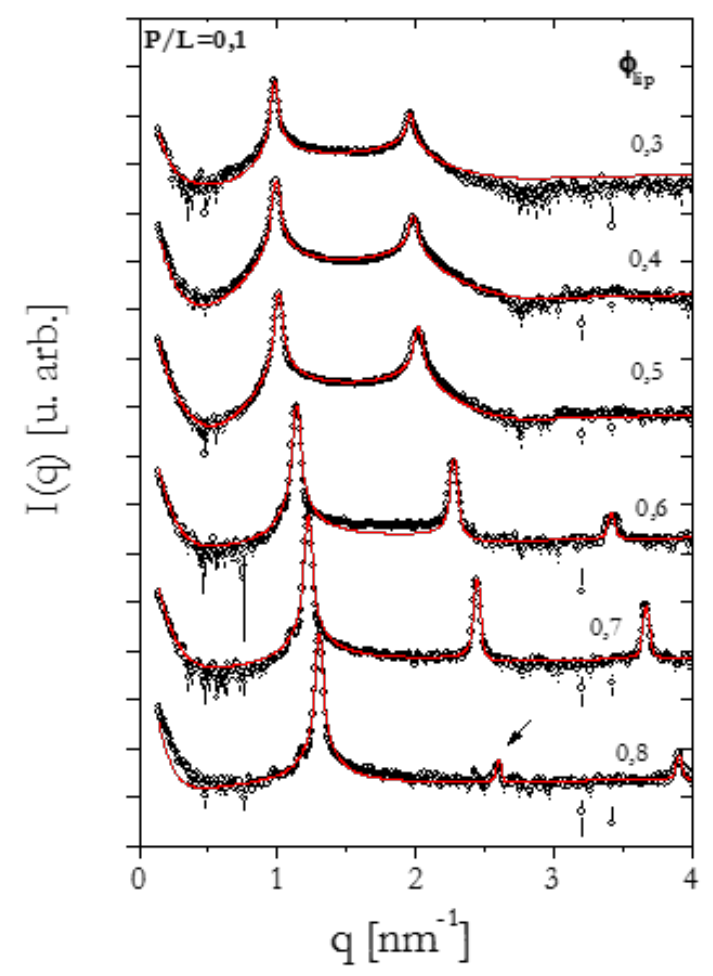

(c)

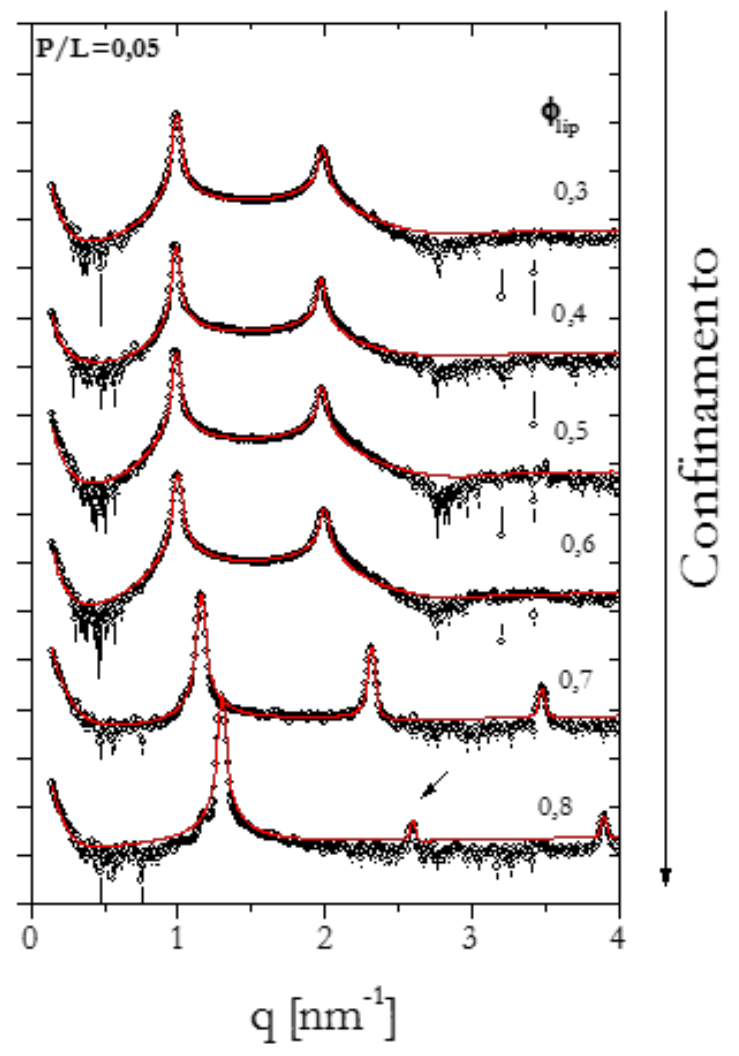

(b)

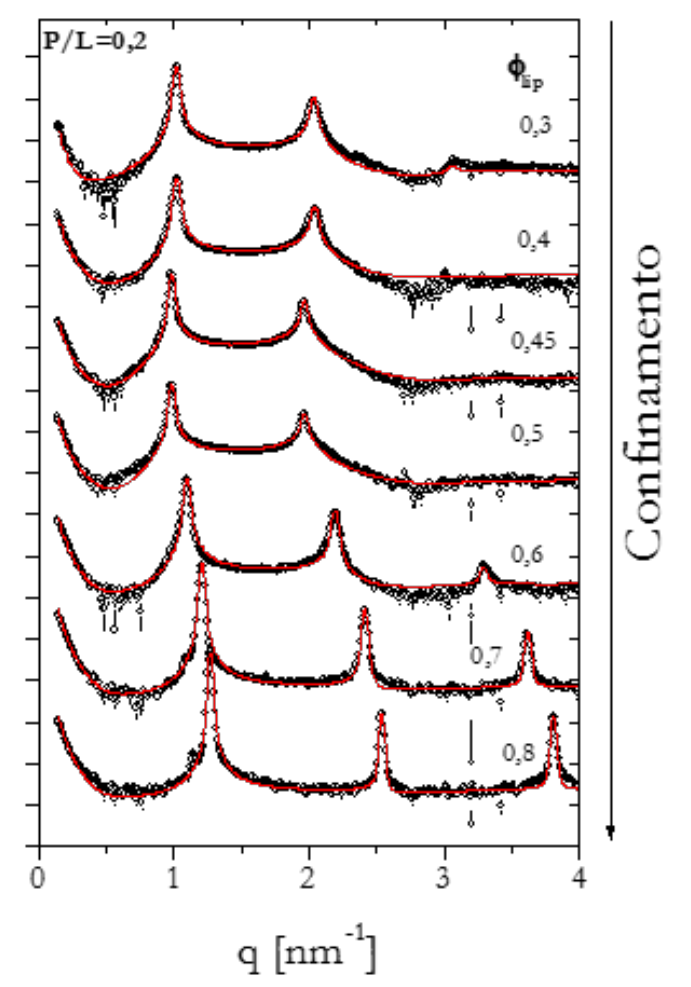

(d)

Figura 0-22: Curvas de I(q) vs. q de SAXS para fases lamelares compostas de peptídeo-lipídio com diferentes razões molares de peptídeo. Para cada razão molar variou-se a fração volumétrica de água (a) $\mathrm{P} / \mathrm{L}=0,001$ (b) $\mathrm{P} / \mathrm{L}=0,01$ (c) $\mathrm{P} / \mathrm{L}=0,1$ (d) $\mathrm{P} / \mathrm{L}=0,2$. 
Ao confinar a fase lamelar, os picos de Bragg deslocam-se para valores maiores de $q$, indicando que a periodicidade lamelar diminui. A intensidade relativa entre os picos de primeira e segunda ordem diminui à medida que a fração volumétrica de água aumenta, e isto pode ser um indicativo de mudanças na estabilização da fase lamelar, tais como alterações na forma da bicamada e/ou na elasticidade, como observado para a fase lamelar de lecitina pura.

Observa-se que para algumas curvas de espalhamento os picos de segunda ordem apresentam intensidade menor do que os picos de terceira ordem, (Figura 0-22 (b)), isto é um indicativo que o fator de forma da bicamada muda com o confinamento. Com a incorporação do peptídeo na membrana observa-se que o pico de terceira ordem torna-se mais largo e difuso indicando o aumento das flutuações da membrana e a redução do comprimento de correlação da ordem lamelar.

Na Figura 0-22 também são apresentados os ajustes das curvas de SAXS com o modelo de 4 gaussianas descrito na seção Fator de estrutura e 
Fator de forma. Em toda a extensão da curva experimental o ajuste é muito satisfatório, fornecendo, além do valor da periodicidade lamelar, o parâmetro de Caillé $(\eta)$, a espessura da bicamada eletrônica $\left(\delta_{M}^{e l e}\right)$ e o perfil do contraste de densidade eletrônica $(\Delta \rho)$.

Considerando o modelo de bicamadas rígidas e a lei de diluição (Eq. II-1) construiu-se um gráfico $D \times \frac{1}{\phi_{l i p}}$, apresentado na Figura 0-23, para as diferentes razões P/L estudadas. Observa-se uma região, com periodicidade lamelar aumentando linearmente de 4,8 nm a 6,3 nm. A concentração de peptídeos não muda a inclinação da reta, que está relacionada a espessura geométrica da membrana.

$\mathrm{Na}$ segunda região, em $\phi_{\text {lip }}>0,55$, a periodicidade lamelar atinge o valor máximo e se mantém constante em torno de $6,38 \mathrm{~nm}$. Esse corresponde ao limite de hidratação da membrana, que é $0,1 \mathrm{~nm}$ superior ao obtido para membranas compostas apenas de lecitina. Aumentando a hidratação a fase lamelar, com periodicidade máxima, coexiste com excesso de água.

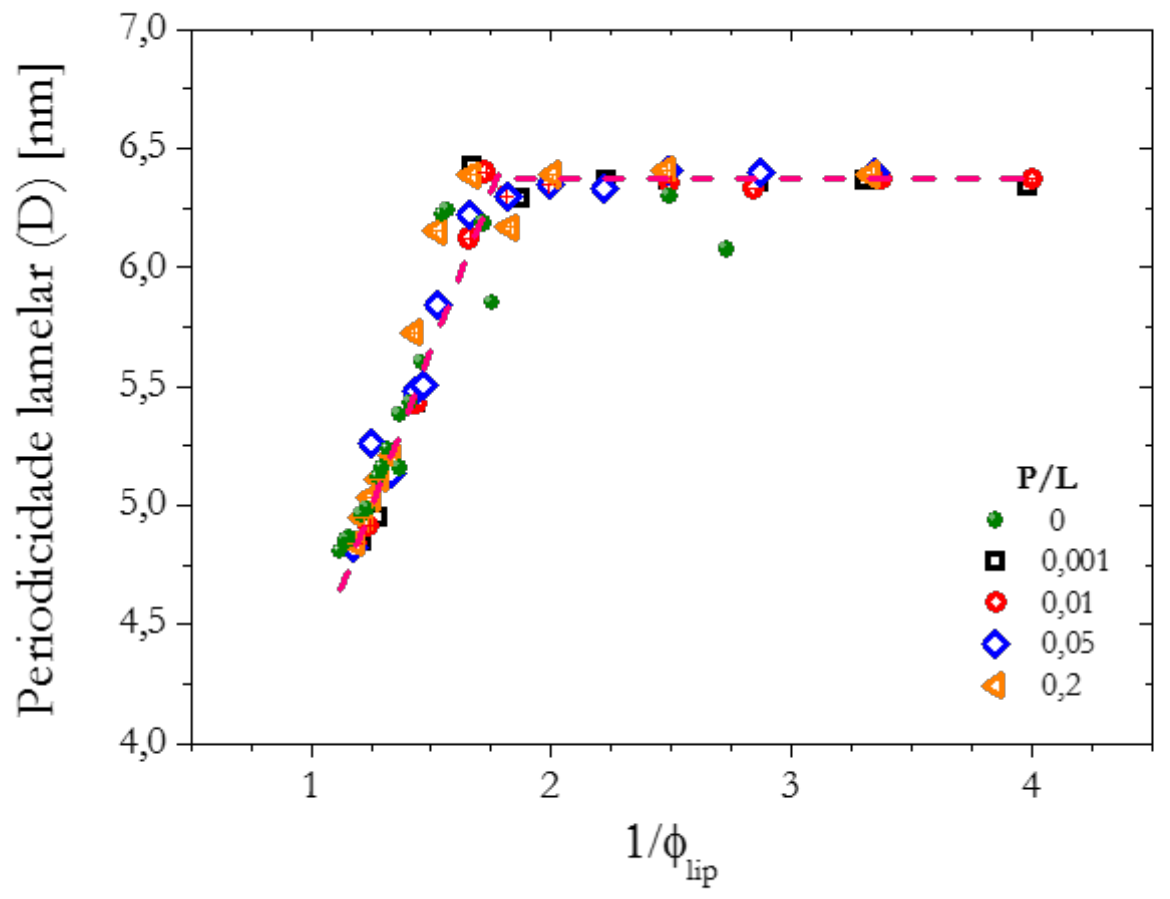

Figura 0-23 Comportamento da periodicidade lamelar em função do inverso da fração volumétrica de lipídio para diferentes razões de $\mathrm{P} / \mathrm{L}$ e para a lecitina pura. As linhas tracejadas são apenas guia para os olhos.

O comportamento da espessura da bicamada eletrônica $\left(\delta_{M}^{\text {ele }}\right)$ é apresentada na Figura 0-24 (a), e observa-se que de modo geral $\delta_{M}^{e l e}$ contendo peptídeo é maior do que a da membrana de lecitina pura (Oliveira et al., 2012) e aproximadamente constante, independente da razão P/L para 
$\mathrm{P} / \mathrm{L}<0,1$ (Figura 0-24 (a)). Quando $\mathrm{P} / \mathrm{L}=0,2$, a espessura eletrônica parece variar com a hidratação aumentando ligeiramente (em torno de $0,8 \mathrm{~nm}$ ) com o aumento do confinamento Figura 0-24 (b)).

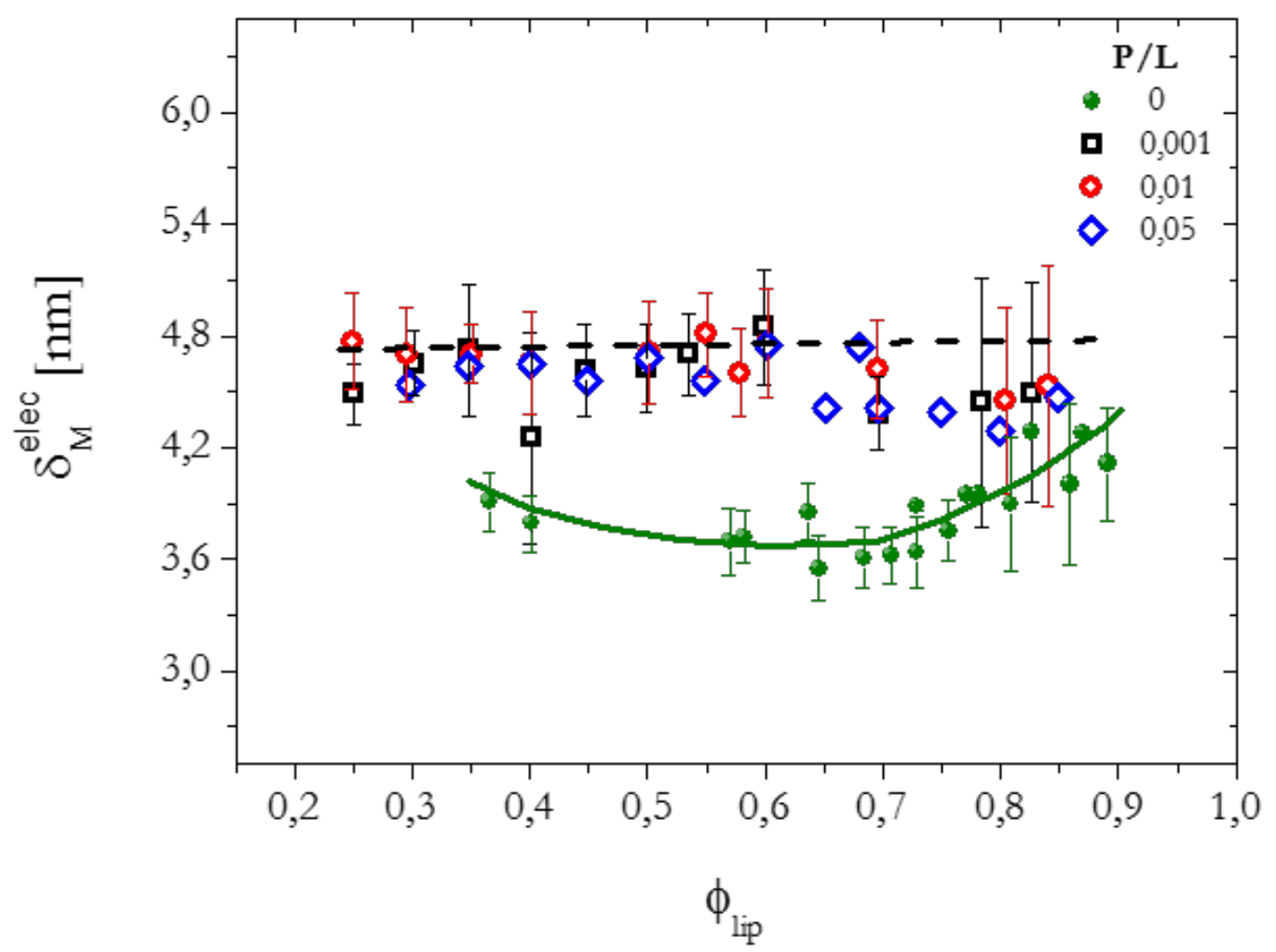

(a) 


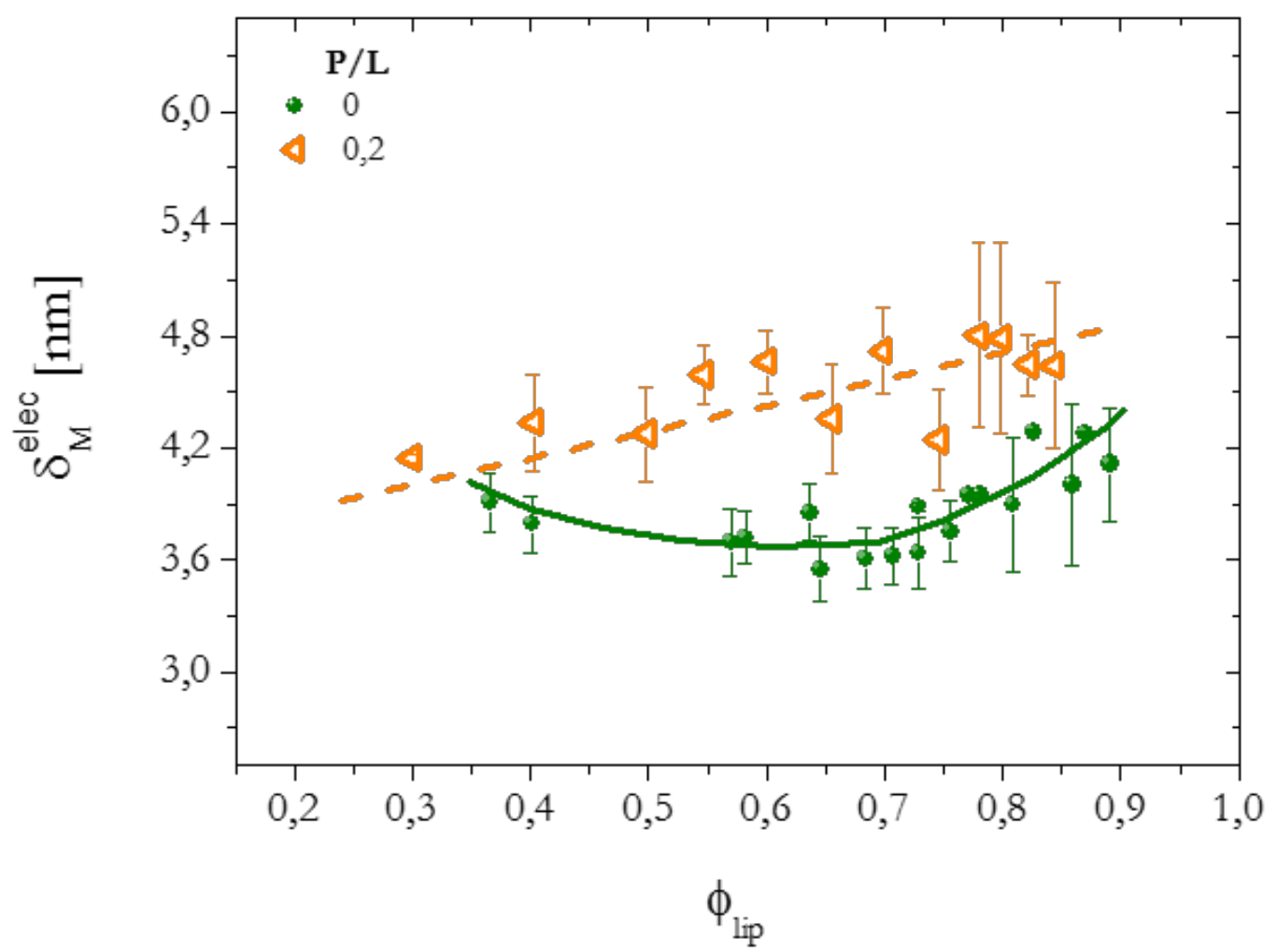

(b)

Figura 0-24 - Comportamento dos parâmetros ajustados (a) espessura eletrônica da bicamada. (b) Inset do comportamento da espessura da bicamada eletrônica para $\mathrm{P} / \mathrm{L}=0,2$ comparada com a lecitina pura (Oliveira et al., 2012). As linhas tracejadas e contínua são apenas guias para os olhos.

O comportamento do perfil do contraste de densidade eletrônica para duas razões de $\mathrm{P} / \mathrm{L}$ são apresentados na Figura 0-25 (a) e (b) com $\mathrm{P} / \mathrm{L}=0,001$ e $\mathrm{P} / \mathrm{L}=0,2$, respectivamente. Com o aumento da fração volumétrica de lipídio as membranas ficam mais próximas e o efeito do confinamento promove a diminuição das amplitudes das flutuações térmicas. Para as membranas contendo baixa quantidade de peptídeo (Figura 0-25 (a)), os picos correspondentes a região polar da bicamada se tornam mais estreitos e bem definidos com o confinamento. Com o aumento da concentração de peptídeo, $(\mathrm{P} / \mathrm{L}=0,2)$, o efeito do confinamento das membranas é dado pelo alargamento da região da interface da bicamada-solvente. 


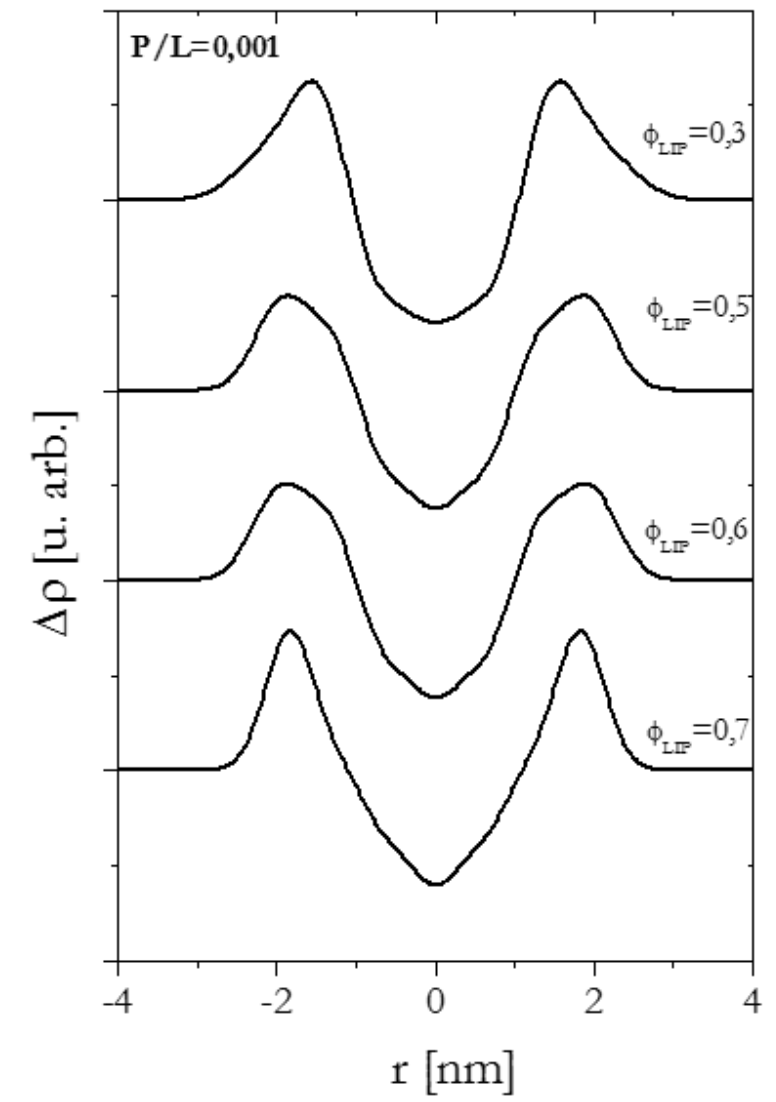

(a)

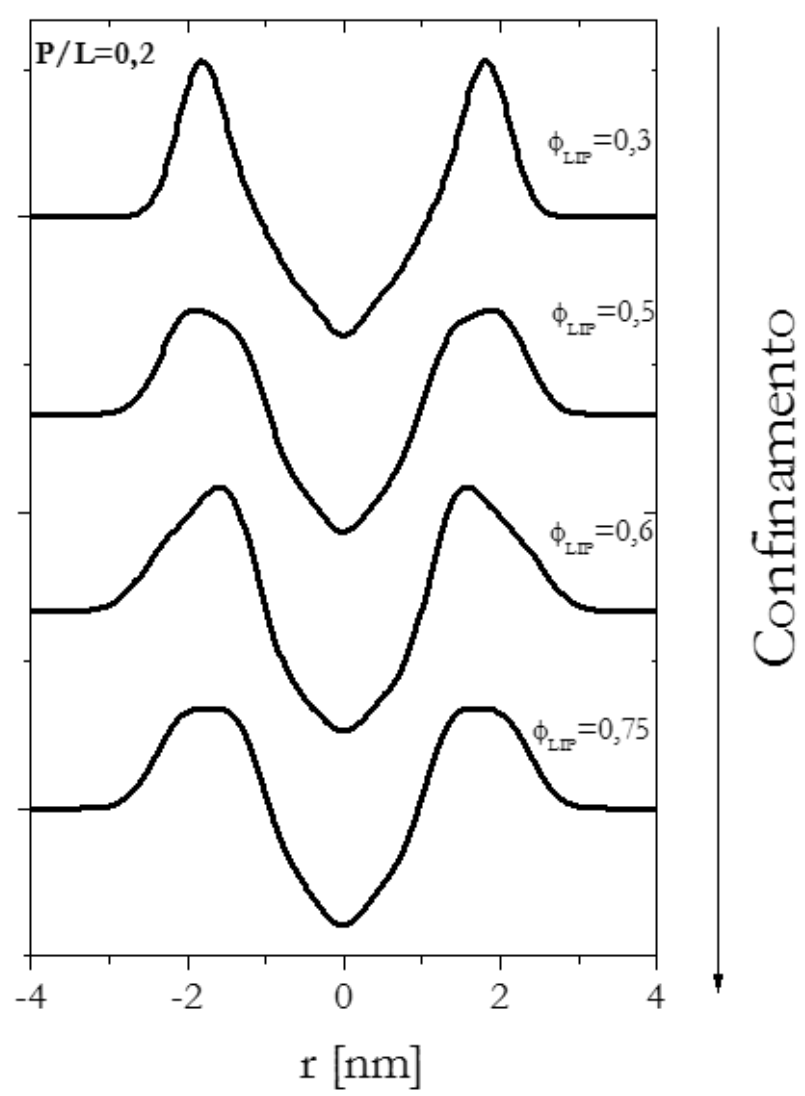

(b)

Figura 0-25: Comportamento do perfil do contraste de densidade (a) $P / L=0,001$ e (b) $P / L=0,2$

A Figura 0-26 mostra o comportamento do parâmetro de Caillé em função da fração volumétrica de lipídio para diferentes razões de P/L. Para baixas concentrações de peptídeo observa-se um comportamento semelhante ao exibido pela fase lamelar composta apenas de lecitina, com valor igual a 0,09 para $\phi_{\text {lip }}<0,6$. No regime confinado, para $\phi_{\text {lip }}>0,6$ a estrutura lamelar se torna mais rígida, isso é mais acentuado para razões de $\mathrm{P} / \mathrm{L}>0,01$, como pode ser observado na Figura 0-26. Para $\mathrm{P} / \mathrm{L}=0,2$ os valores de parâmetro de Caillé são três vezes maiores que as membranas com $\mathrm{P} / \mathrm{L}<0,05$ (detalhe da Figura 0-26). É possível que esse comportamento esteja relacionado a auto-associação dos peptídeos, evidenciada nos experimentos de WAXS. Os agregados de peptídeos passariam a atuar como defeitos locais conferindo uma certa flexibilidade á estrutura lamelar. Essa interpretação é compatível com a tendência de aumento da espessura eletrônica para essa concentração de peptídeo. 


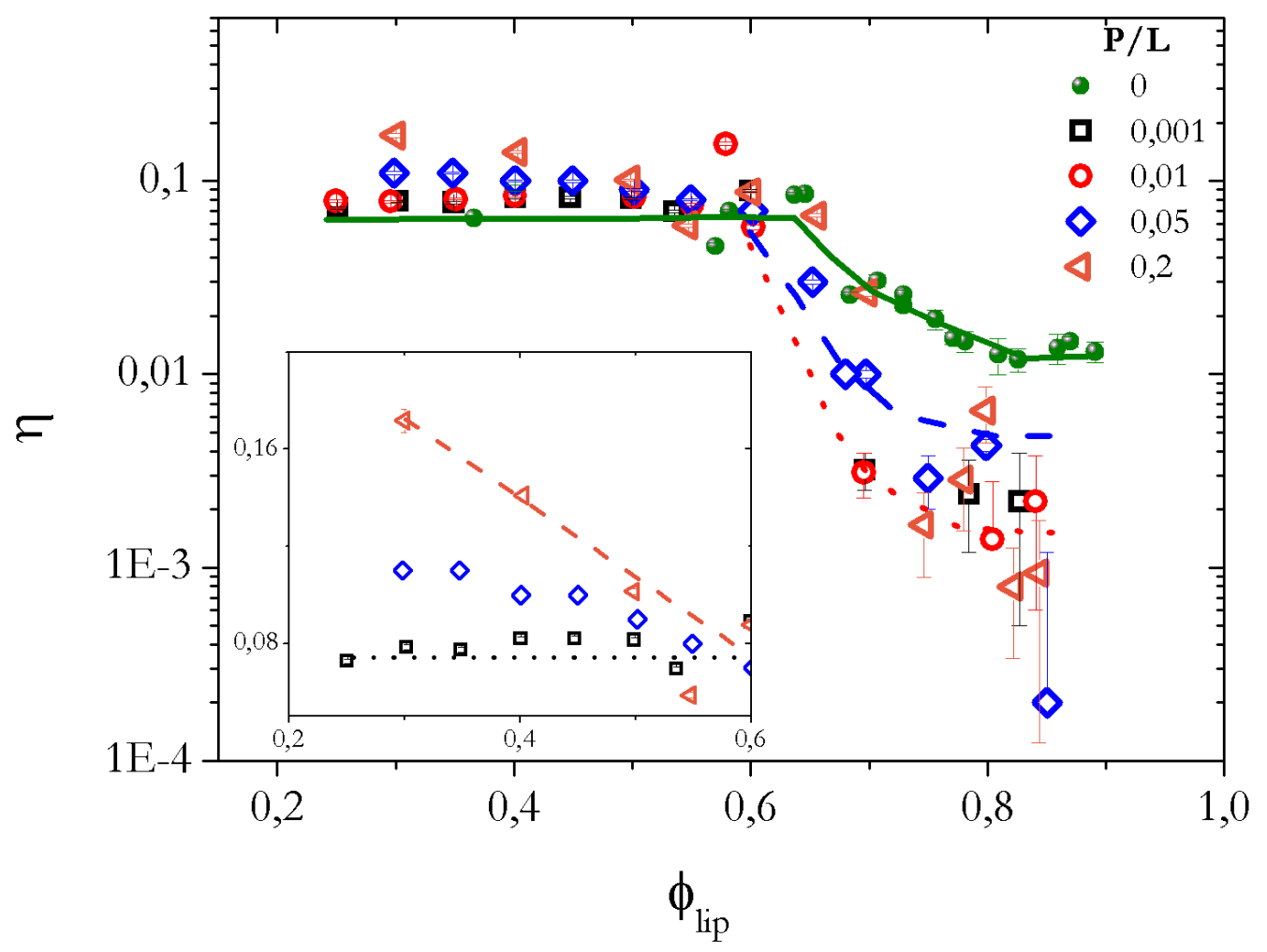

Figura 0-26 Parâmetro de Caillé em função da fração volumétrica de lipídio. As linhas são apenas guia para os olhos.

Utilizando-se a equação $\Sigma=2 \frac{v}{D \cdot \phi_{\text {lip }}}$ (Bougis, 2016), pode-se calcular a área por molécula na interface $(\Sigma)$, onde $v$ é o volume molar levando-se em conta a razão $\mathrm{P} / \mathrm{L}$. Tanto o volume molar quanto $\phi_{\text {lip }}$ são parâmetros oriundos da preparação da amostra, enquanto $D$ é obtido pelo ajuste das curvas experimentais de SAXS. Na Figura 0-27 (a) é apresentado o gráfico $\Sigma \times$ D. Este gráfico nos permite observar o comportamento do confinamento lateral pelo confinamento vertical (Bougis, 2016). A área por molécula na interface é praticamente constante para periodicidade lamelar de até $6,2 \mathrm{~nm}$. Após este valor, $\Sigma$ aumenta rapidamente até atingir um valor limite. Ao se comparar estes resultados com aqueles obtidos para a lecitina pura (Figura 0-27 (b)) (Bougis, 2016), observa-se o mesmo comportamento, e isto já seria esperado, uma vez que o volume ocupado pela lecitina é cerca de 10 vezes o volume ocupado pelo peptídeo. Portanto, a contribuição para a área por molécula na interface é predominantemente dada pela área ocupada pela molécula de lecitina. 


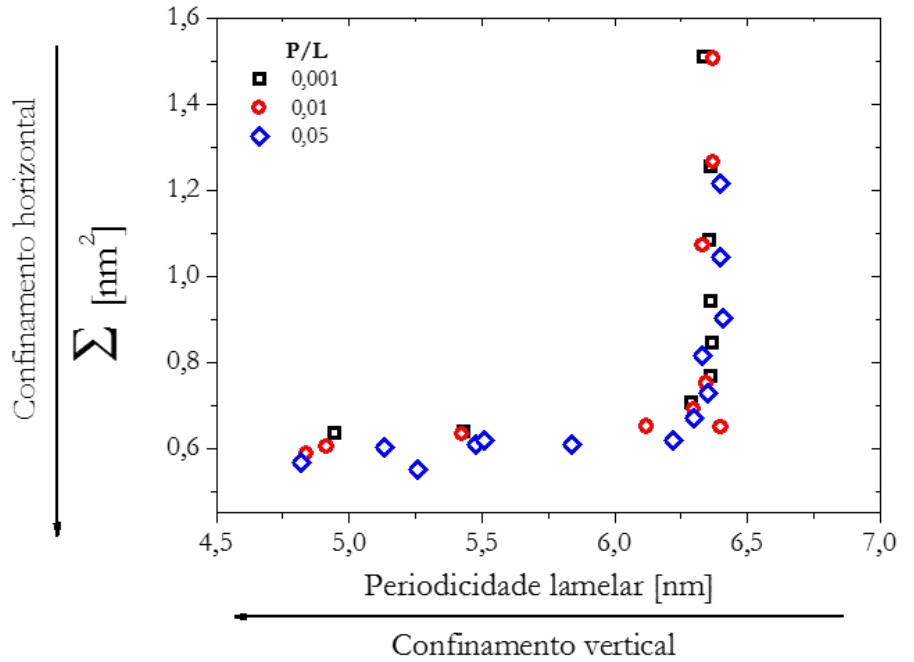

(a)

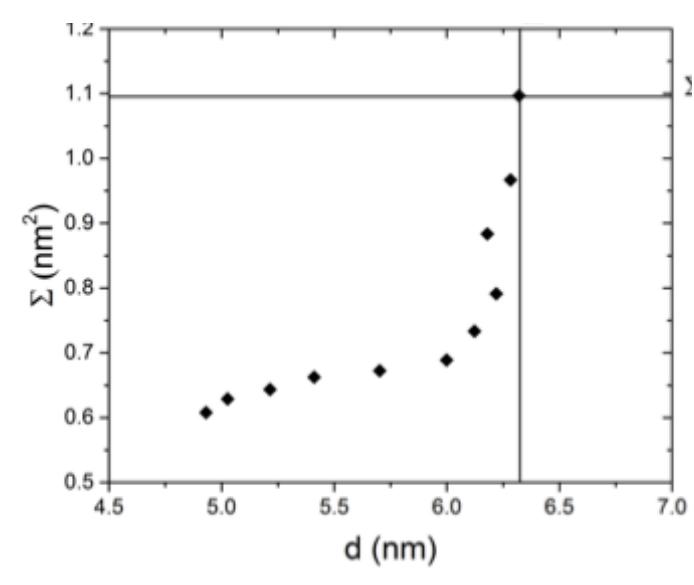

(b)

Figura 0-27 Comportamento da área por cabeça polar em função da periodicidade lamelar(a) para o complexo peptídeo-lipídio com diferentes razões de P/L e (b) lecitina pura. Extraída de (Bougis, 2016).

A espessura geométrica pode ser determinada pela Eq. II-1 para cada fração volumétrica de lipídio e, quando descrita desta forma, leva em conta apenas as flutuações na direção perpendicular á membrana. No entanto, reescrevendo-a como $\delta_{m}^{g e o}=2 \frac{v}{\Sigma}$, é possível investigar as mudanças que ocorrem no plano da membrana.

$\mathrm{Na}$ Figura 0-28 (a) é apresentado o comportamento da espessura geométrica em função da área por molécula na interface. Para todas as composições P/L estudadas, o comportamento de $\delta_{M}^{g e o}$ decresce com o aumento de $\Sigma$. Para a lecitina pura (Figura 0-28 (b)) (Bougis, 2016)) observase a forma de um potencial tipo "caroço duro", que lembra o potencial do tipo Lenard-Jones, com uma região atrativa e outra repulsiva. No caso da lecitina pura isto pode ser interpretado em termos da reorganização das moléculas lipídicas conforme a espessura da bicamada varia (Bougis, 2016). Entretanto, não se observa este comportamento para os complexos estudados aqui, indicando que a presença de peptídeo modifica os potenciais de interação entre as bicamadas na estrutura lamelar. 


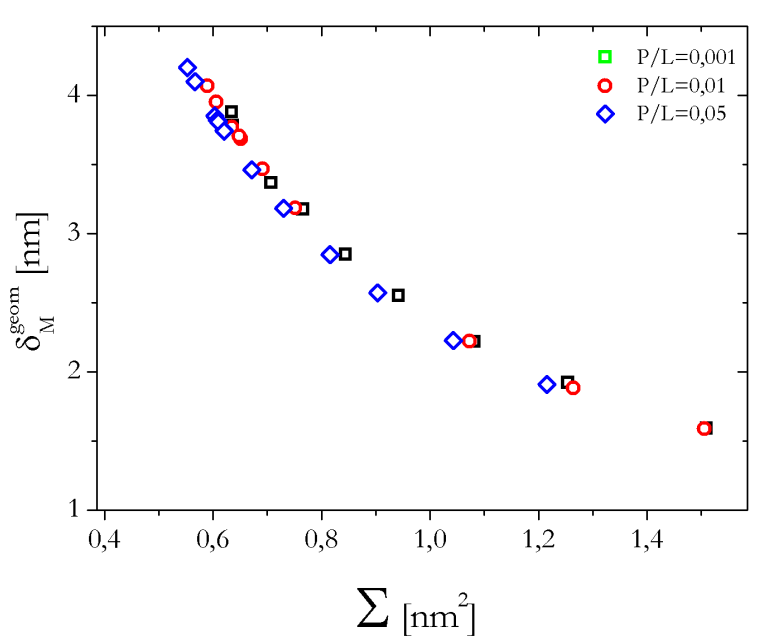

(a)

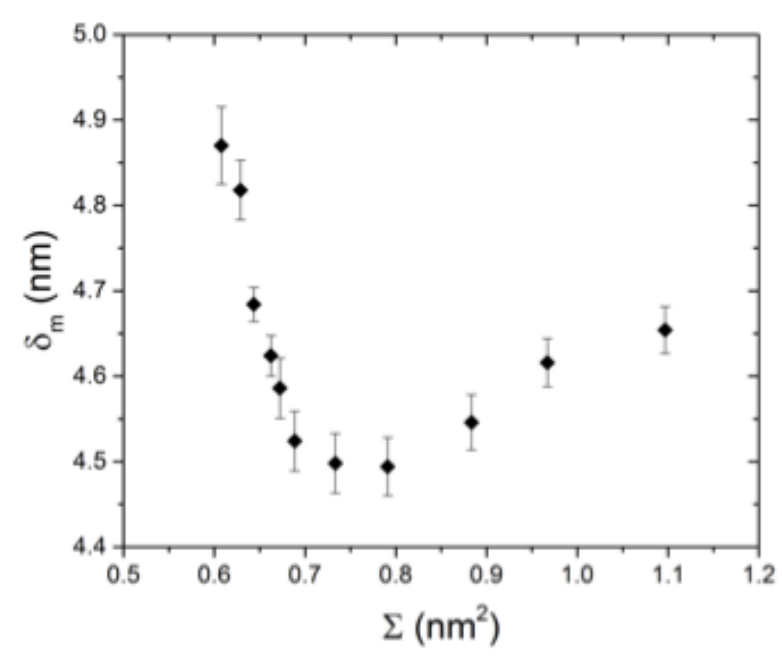

(b)

Figura 0-28 Comportamento da espessura geométrica em função da área por molécula (a) para o complexo peptídeo-lipídio com diferentes razões de P/L e (b) lecitina pura (Bougis, 2016).

As texturas observadas em microscopia de luz polarizada, para amostras com diferentes P/L, são apresentadas na Figura 0-29 . Para baixa concentração de peptídeos (P/L=0,01), (Figura 0-29 (b)) observa-se texturas características de fases lamelares, porém com o aumento da concentração de peptídeo, $\mathrm{P} / \mathrm{L}=0,05$ (Figura 0-29 (d)), já é possível observar a formação de fibras, com dimensões micrométricas. Já para a amostra de $\mathrm{P} / \mathrm{L}=0,2$ (Figura 0-29 (e)), é possível identificar a formação de fibras e a textura lamelar sofre mudanças consideráveis como, por exemplo, com o aparecimento de vesículas.

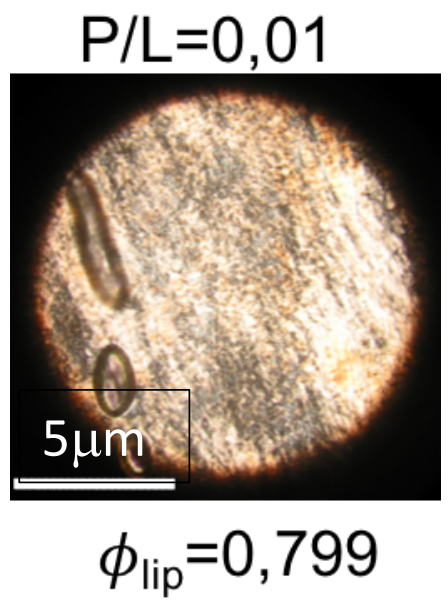

(a)

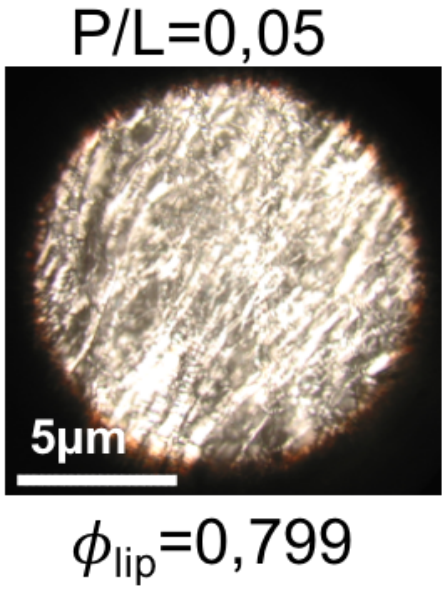

(c)

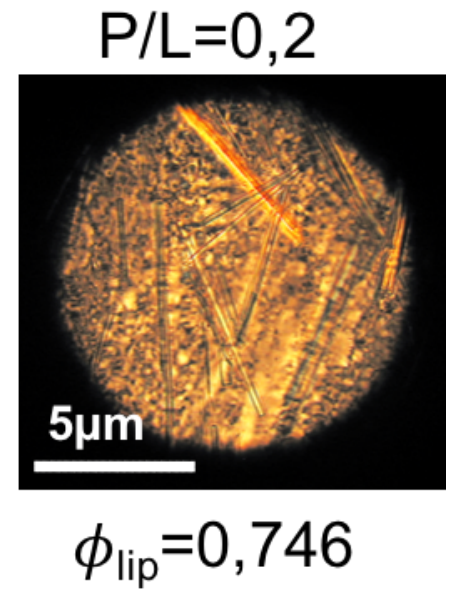

(e) 


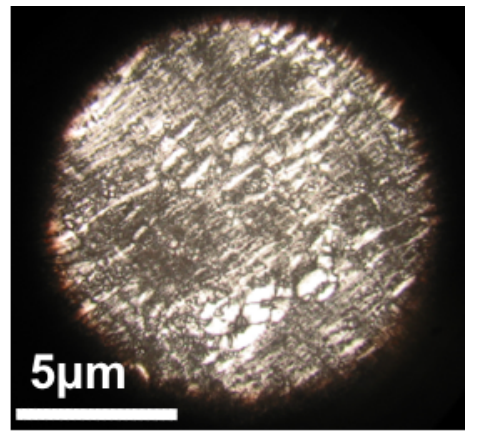

$\phi_{\text {lip }}=0,60$

(b)

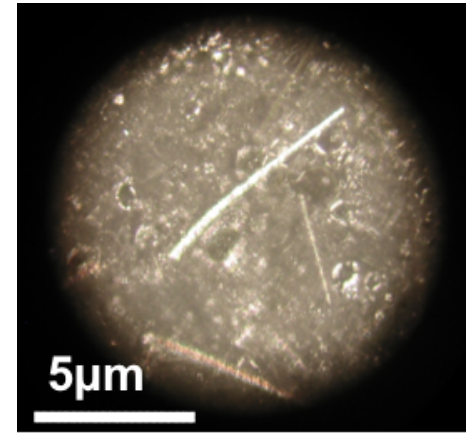

$\phi_{\text {lip }}=0,299$

(d)

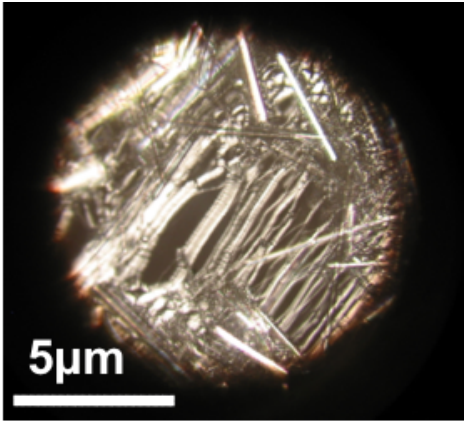

$\phi_{\text {lip }}=0,349$

(f)

Figura 0-29 Texturas em microscopia de luz polarizada, para duas frações volumétricas de lipídeo para diferentes $\mathrm{P} / \mathrm{L}$. 


\section{Discussão}

Os resultados de SAXS mostraram que, para toda a extensão do estudo de hidratação, bem como para todas as razões de $\mathrm{P} / \mathrm{L}$, observou-se a formação de fases lamelares, preservando o caráter fluido da membrana. As curvas de WAXS mostram que com o aumento da concentração de peptídeo, surgem raias de Bragg que podem ser atribuídas a formação de agregados cristalinos de peptídeos com simetria ortorrômbica.

A periodicidade lamelar não é alterada com o aumento da concentração de peptídeo quando comparada ao comportamento da lecitina pura, contudo, outros parâmetros estruturais, tais como, parâmetro de Caillé e espessura eletrônica, são influenciadas pela incorporação do peptídeo na fase lamelar. Em particular, o comportamento da espessura geométrica da bicamada em função da área molecular da interface mostra que a presença do peptídeo na fase lamelar muda interações entre as membranas.

Comparando os resultados obtidos na razão $\mathrm{P} / \mathrm{L}=0,2$ para o sistema confinado e em excesso de água (que promove a formação de vesículas), há uma divergência nas estruturas observadas. Para o sistema em excesso de água (1\% de lipídio) observou-se a formação de vesículas unilamelares, enquanto para o sistema confinado, mesmo no limite de diluição, foram observadas fases lamelares.

Para verificar o efeito da hidratação realizou-se um experimente, partindo de uma amostra que se apresenta na fase lamelar, com a adição de água, em sucessivas diluições. Na primeira diluição de 50\% para as amostras com $\mathrm{P} / \mathrm{L}<0,2$, as curvas de SAXS indicaram que a estrutura da fase lamelar foi preservada (Figura 0-30 (a)). Contudo, para a amostra com razão P/L=0,2, observou-se apenas um pico difuso, característico de vesículas unilamelares (Figura 0-30 (b)). Por um lado, esse experimento confirma a transição multi-unilamelar, observada para as vesículas, e por outro lado, observa-se que a hidratação também desempenha um papel importante na interação entre as membranas. 


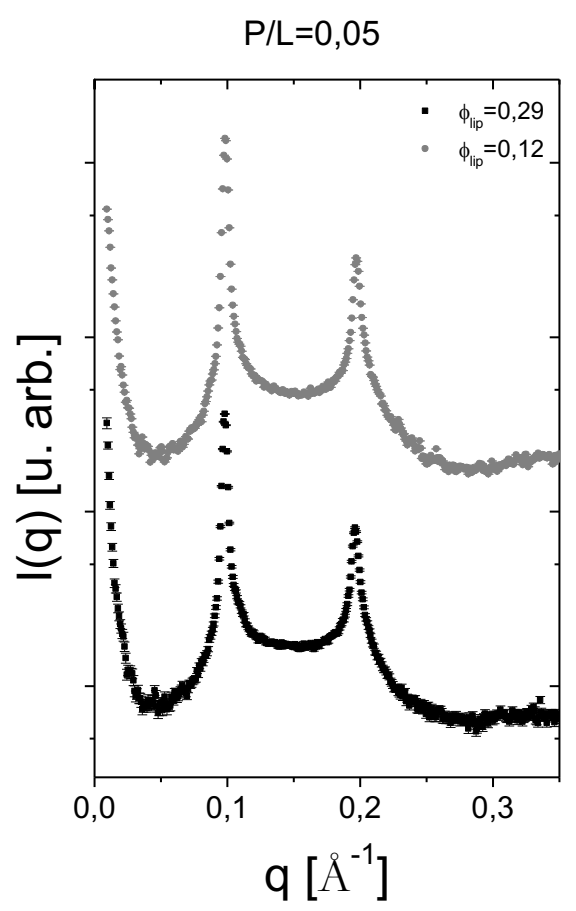

(a)

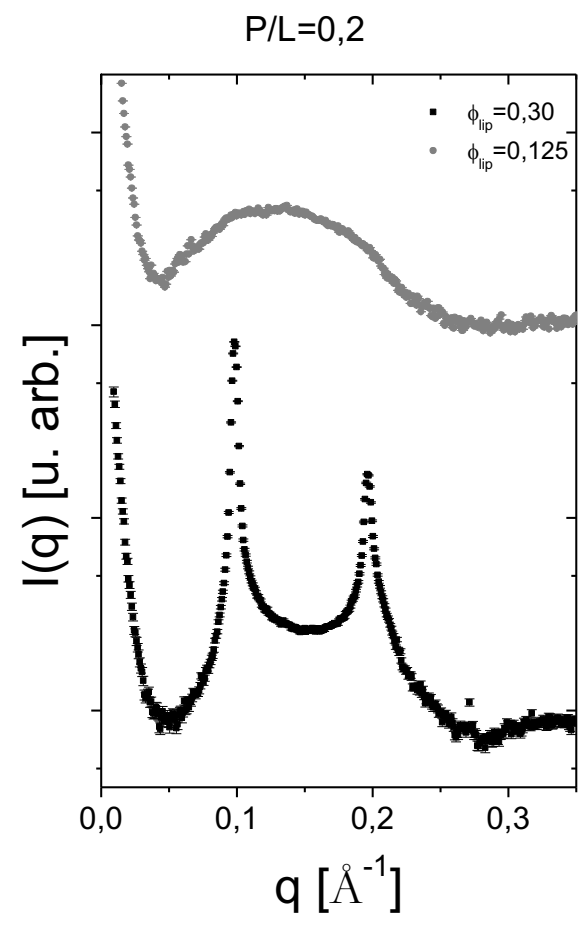

(b)

Figura 0-30 Curvas de SAXS para duas frações volumétricas de lipídio (a) P/L=0,05 e (b) $\mathrm{P} / \mathrm{L}=0,2$. 


\section{CONCLUSÕES E PERSPECTIVAS}

\section{Conclusões}

Este trabalho teve como objetivo o estudo da interação de biomoléculas com fases lamelares, que constituem sistema modelo de membranas. Duas biomoléculas foram utilizadas, em primeiro lugar fragmentos de DNA com 150 pares de base, e que se situam na camada aquosa entre as membranas. Nesse estudo, a fase lamelar consistiu de membranas mais flexíveis em relação a estudos anteriores, com o objetivo de investigar o efeito da elasticidade das membranas no ordenamento dos fragmentos de DNA. Na segunda parte do trabalho, optou-se por uma classe de biomoléculas que se inserem na parte hidrofóbica da membrana e também apresentam propriedades de auto-organização.

Verificou-se que as mudanças de organização dos fragmentos de DNA estão relacionadas com alterações na flexibilidade das membranas e no empacotamento das moléculas de lipídios no interior da bicamada. A partir da formulação do sistema lamelar, composição da bicamada e hidratação, mostrou-se que é possível modular as interações na fase lamelar e que estas podem levar a diferentes tipos de organização espacial em uma escala nanométrica.

No estudo da ação peptídeos em membranas foi demonstrado que as sequencias estudadas, FF e CFF situam-se na interface da membrana e interagem mais fortemente com os grupos fosfato e carboxílico, por meio de ligações de hidrogênio. No caso do tripeptideo CFF, o átomo de enxofre na cadeia lateral favorece a formação de ligações de hidrogênio, confirmando o forte efeito desse peptídeo nos estados vibracionais do grupo fosfato. Esse resultado também é consistente com a constatação de que a CFF tem maior habilidade em promover a transição multilamelar-unilamelar. Como esse peptídeo é mais eficiente em aderir a membrana, a sua organização, mesmo em concentrações baixas, leva a diminuição da entropia local. Nesse caso, a entropia translacional deve aumentar e deve promover a liberação de moléculas de água na vizinhança da interface.

No regime diluído, foi observado que o aumento da concentração de peptídeos promove o aumento do diâmetro das vesículas. Esse efeito está relacionado a mudanças moderadas em suas propriedades elásticas e nas interações entre as bicamadas, que resulta na transição multilamellarunilamelar.

Os experimentos de espalhamento de raios X trazem evidencias que o caráter fluido é preservado, mesmo em altas concentrações de peptídeos, porém as interações entre elas são modificadas. É importante ressaltar que mesmo essa sequencia curta de aminoácidos, reconhecida 
como elemento chave presente na proteína amiloide $A_{\beta}$ (1-42), pode se auto-associar e formar estruturas cristalinas que modificam a elasticidade da membrana.

Parte dos resultados apresentados nesta tese foram organizados em um artigo aceito para publicação. 


\section{Perspectivas}

Como perspectiva, o estudo sistemático do complexo FF-lipídio apresentado nesta tese para a região de confinamento será utilizado para a redação de um próximo artigo científico.

Foram também realizados experimentos de SAXS para as amostras CFF para duas razões $\mathrm{P} / \mathrm{L}, \mathrm{P} / \mathrm{L}=0,001$ e $\mathrm{P} / \mathrm{L}=0,1$, na região de confinamento. Os dados de SAXS mostram que, mesmo para baixas concentrações de peptídeo na região mais hidratada, as curvas de espalhamento mudam consideravelmente, assim como os parâmetros estruturais. Como perspectiva, serão preparadas amostras com maior concentração deste peptídeo para a realização de um estudo sistemático da incorporação CFF na membrana lipídica. Os resultados serão utilizados para a redação de outro artigo científico.

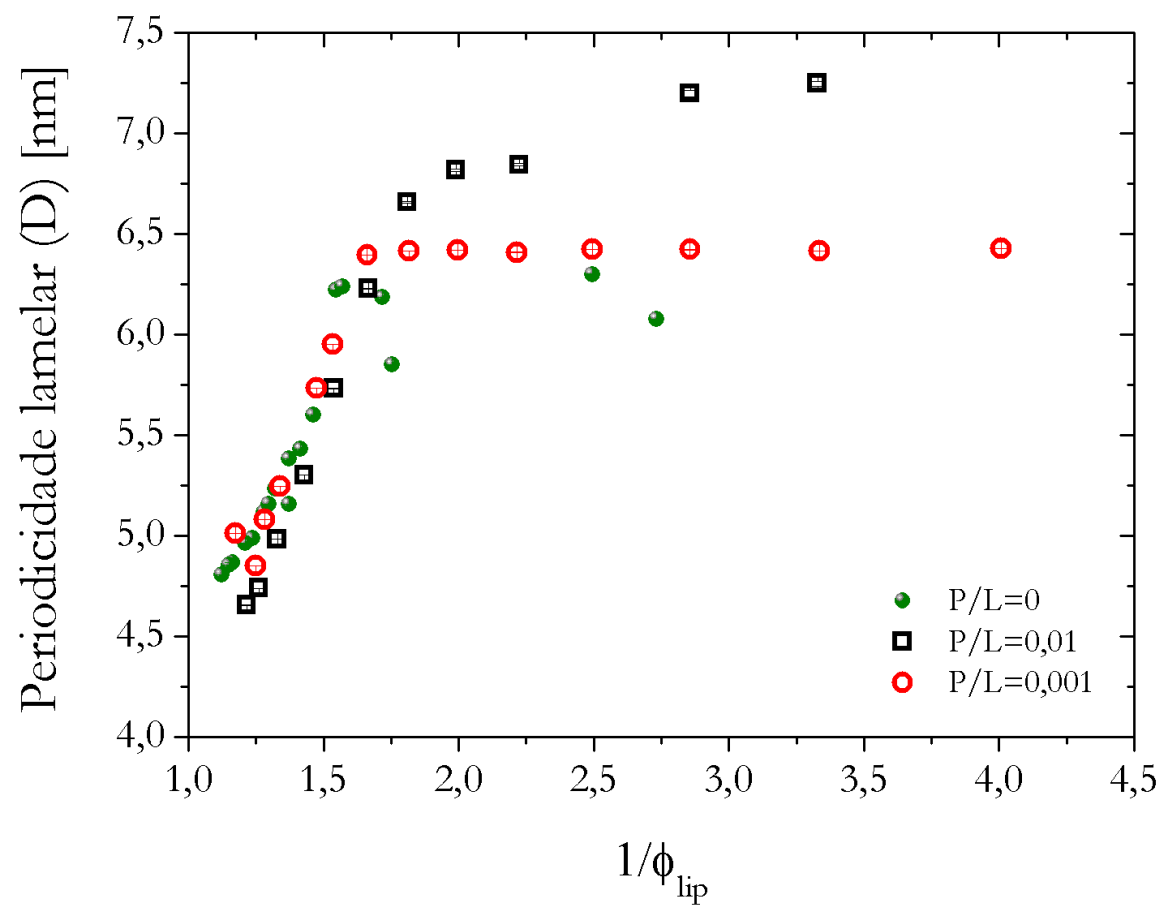

Figura 0-1 Comportamento da periodicidade lamelar em função do inverso da fração volumétrica de lipídio para diferentes razões de $\mathrm{P} / \mathrm{L}$ e para a lecitina pura. 


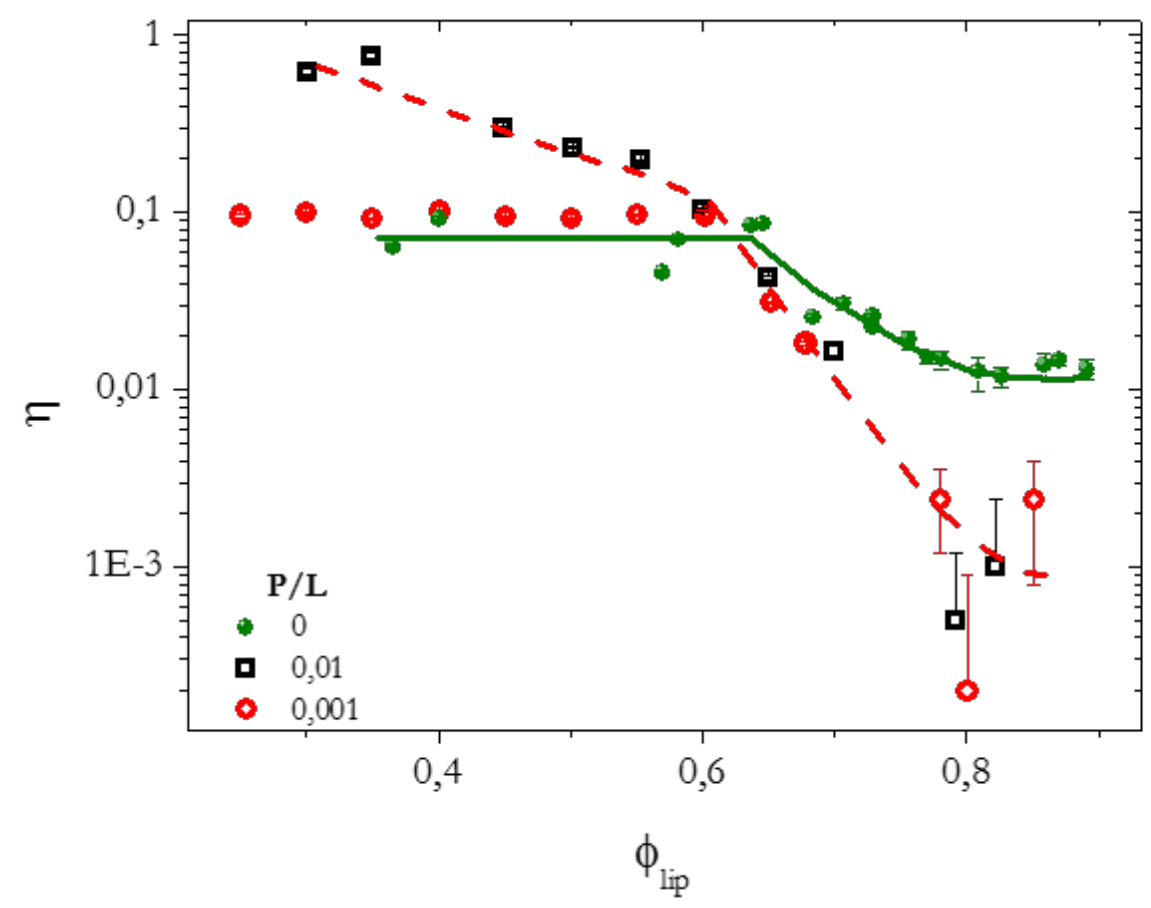

(a)

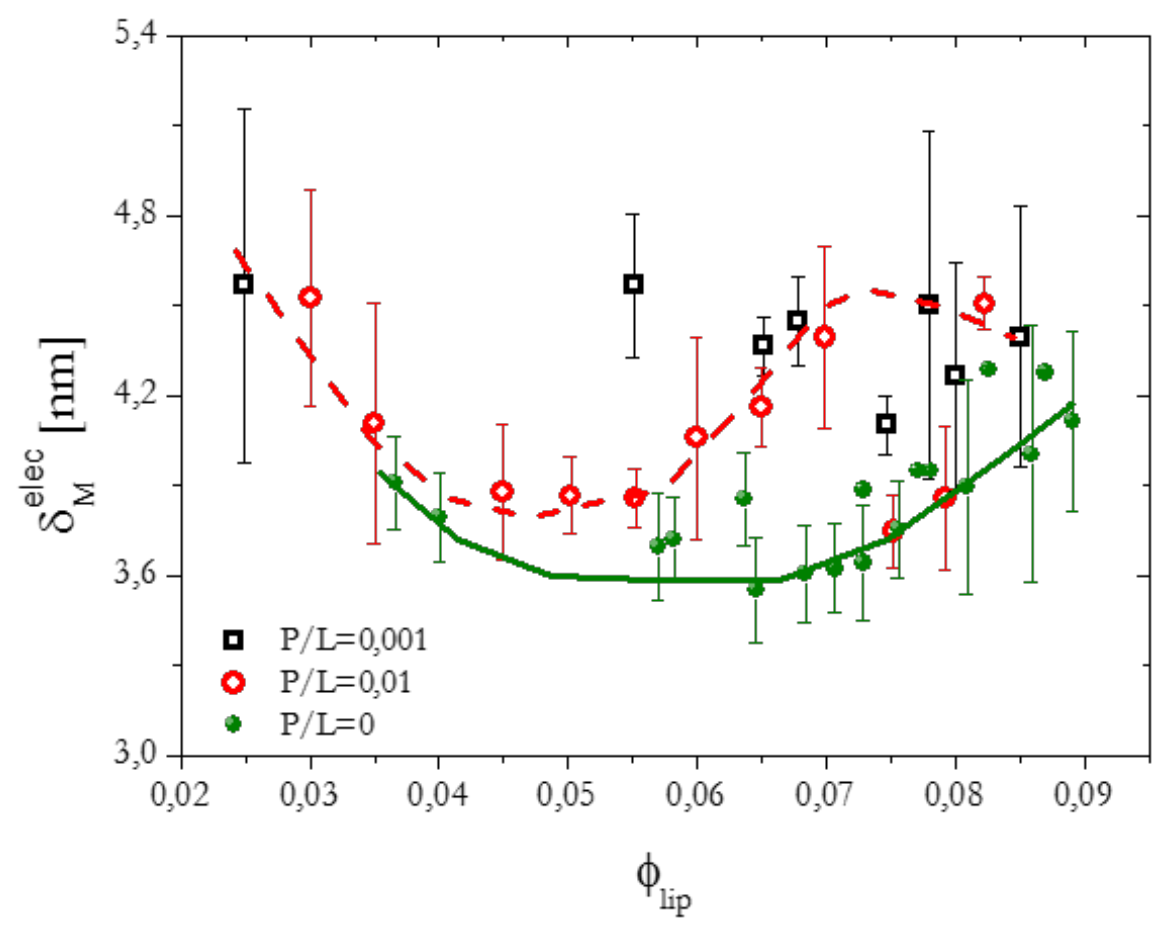

(b)

Figura 0-2: Comportamento dos parâmetros estruturais para o peptídeo CFF. (a) Comportamento do parâmetro de Caillé. (b) Espessura da bicamada. Onde as linhas são apenas guia para os olhos. 


\section{ANEXO 1}

\section{Desalinização do DNA e processo de sonicação}

- Em um tubo de ensaio, pôr $100 \mathrm{mg}$ de DNA (timo de boi) + $10 \mathrm{ml}$ de água pura. Agitar durante 1 ou 2 horas e então deixe descansar uma noite.

- Adicione 1/10 deste volume de acetato de sódio a 3 M, pH 5,2 (solução de acetato de sódio para biologia molecular, Sigma-Aldrich. Ref. S7899-500ml).

- Então adicione 2,5 vezes o volume $(25 \mathrm{ml})$ de etanol ultrapuro e agite. Vê-se o DNA precipitar como um algodão. Congele a $-80{ }^{\circ} \mathrm{C}$ durante a noite.

- No dia seguinte, centrifugue o tubo a $5200 \mathrm{rpm}$ (3500g) por 15 minutos a $4 \circ \mathrm{C}$. O sobrenadante é descartado e o DNA é retirado em $10 \mathrm{~mL}$ de etanol 70\%.

- Agite o tubo manualmente e deixe a` temperatura ambiente por 1 hora. Então centrifugue do mesmo modo, $5200 \mathrm{rpm}, 4^{\circ} \mathrm{C}$, por 15 minutos.

- Após a terceira repetição do processo acima, o sobrenadante é descartado e então o DNA é seco em uma liofilizadora durante 2 dias para remover qualquer traço de etanol.

- O DNA é então colocado em solução aquosa H2O, a $10 \mathrm{mg} / \mathrm{ml}$. Então os tubos são sonicados em um banho de ultrasom. Esta técnica é preferida ao invés de um sonicador com ponteira.

\section{Marcação do DNA}

YOYO-1 (491/509) da Invitrogen é comprado em soluções de 1 mM. Para preparação de $150 \mathrm{mg}$ de DNA marcado com YOYO:

- Coloque $150 \mathrm{mg}$ de fragmentos de DNA sonicado (liofilizado) e em água pura ( $\approx 10 \mathrm{ml})$.

- Agite por 1 hora.

- Adicione 49,5 $\mu \mathrm{l}$ da solução estoque de YOYO.

- Agite por 1 hora, ao abrigo da luz.

- Congele a $-80{ }^{\circ} \mathrm{C}$ por 2 horas (mínimo) antes da liofilização. 
ANEXO 2

\section{Artigo aceito na revista Langmuir DOI:10.1021/acs.langmuir.7b03869}

\section{Multilamellar-to-unilamellar transition induced by diphenyalanine in lipid vesicles}

Barbara Bianca Gerbelli ${ }^{1}$, Emerson Rodrigo da Silva ${ }^{2}$, Bruna Miranda Soares ${ }^{3}$, Wendel Andrade Alves $^{3}$ and Elisabeth Andreoli de Oliveira ${ }^{1}$

${ }^{1}$ Instituto de Física, Universidade de São Paulo, São Paulo 05314-970 Brazil

${ }^{2}$ Departamento de Biofísica, Universidade Federal de São Paulo, São Paulo 04023-062

${ }^{3}$ Centro de Ciencias Naturais e Humanas, Universidade Federal do ABC, Santo André 09210580, Brazil

\section{Abstract}

In the present work, we investigate the effect of two short phenylalanine-based peptides on lipid membranes. $A$ simplified model membrane composed of lecithin vesicles was used to incorporate different amounts of the two amino acid sequences, the dimmer L,L-diphenylallanine (FF) and the trimmer cysteine-diphenylallanine (CFF). Spectroscopic and scattering techniques were applied to probe in detail the structural behavior of lipid membranes in presence of the peptides. The experimental results demonstrate that both peptides are located mainly at the interface of the membrane interacting with phosphate groups modifying membrane thickness and flexibility. The multilamellar structure of the vesicles is preserved with inclusion of small amounts of FF, accompanied by changes in membrane thickness and elasticity. Finally, a multi to unilamellar transition is observed as a result of peptide self-association into a crystalline structure onto the membrane interface. 


\section{INTRODUCTION}

Since the laying of the fluid-mosaic model ${ }^{1,2}$ in the early 1970's, biological membranes have been understood as complex systems wherein an intricate balance between lipids and proteins is responsible for structure, signaling, regulation and transport in living cells ${ }^{3,4}$. Among the species embedded in the cell membranes, peptides play a key role in a variety of cellular processes, ${ }^{5}$ therefore, understanding their action on lipid membranes is crucial for developing new therapeutic approaches for a large class of human diseases.

A frequent approach to investigate the action of peptides in cell membranes has been the use of simplified systems with model lipid membranes and, sometimes, short sequences of amino acids. Particularly, many research efforts have been devoted to investigating the interaction of antimicrobial peptides (AMPs) and mimetic biological membranes made up from lipid blends based on phosphatidylcholines. ${ }^{6,7,8,9,10}$ Although the global effects depend on mutual properties of lipids and peptides, some common features have been identified and, in general, perturbations on the membrane structure remain small for low peptide concentration. For instance, low amounts of AMPs have been shown to induce local changes of curvature and thinning of lipid bilayers driven by direct electrostatic interactions between charged groups available on both amino acid side chains and lipid polar heads. ${ }^{11,12,13,14,15}$ Multi-to-unilamellar transition on DPPC bilayers has also been reported for more complex molecules such as a cationic $\mathrm{C}_{16}-\beta \mathrm{AH}$ lipopeptide $\left(\mathrm{C}_{16}\right.$ : 16 carbon alkyl chain, A:alanine and H:histidine) ${ }^{16}$ which mimics both shape and amphipaticity of surfactant moieties. However, as the concentration of peptides increases, permeation and formation of pores may occur, affecting lipid ordering and membrane stability. ${ }^{14,17,18,19}$ It has been proposed that self-association of peptides forming more complex structures plays a crucial role for membrane lysis. ${ }^{13}$

The aggregation and self organization of peptides have been widely studied in the last years due to their implication in neurodegenerative pathologies and also due to their potential application in developing ordered structures at nanometric scale. ${ }^{20}$ The presence of aromatic residues in these sequences has been considered a key factor for promoting both order and directional growth via $\pi$-stack interactions. ${ }^{21}$ It has been demonstrated that sequences containing L-phenylalanine can self-assemble into a large variety of polymorphs, including tubular structures, ${ }^{22}$ nanowires ${ }^{23}$ and spherical vesicles. ${ }^{24,25,26}$ Herein, we focus on two short peptides based on phenylalanine since this residue is known to have a crucial role in the formation of nanoscopic self-assemblies and it appears associated to a variety of biological phenomena. We investigate the effect of the dimmer $L, L-$ diphenylallanine (FF) and the trimmer $L$-cysteine- $L, L$-diphenylallanine (CFF) on the organization 
lecithin membranes. Using these short peptide sequences provides a double advantage for investigating peptide/lipid membrane interactions: by one hand, they limit the number of chemical species on the interplay at membrane interfaces, simplifying the interpretation of experimental results. By the other hand, the absence of net charge in both peptide sequences and lecithin membranes opens an experimental window for probing the role of other forces beyond direct electrostatic interactions found to drive interactions in AMPs based systems. ${ }^{17}$ The choice for the cysteine residues has been inspired by the extensive presence of this neutral amino acid in AMPs found in different organisms, where disulfide bonds are thought to play a major role for membrane disruption. ${ }^{27,28}$ In addition, the polar nature of cysteine side-chains provides amphiphilic features to the peptide and enables to probe interactions at membrane interface. The short sequences were incorporated into lecithin vesicles, which have been widely used as phospholipids model to mimic cell membranes. ${ }^{14,18,29}$

We use a sophisticated combination of analytical tools including, microscopy, scattering and spectroscopy methods. The set of techniques provided a multiscale picture on the structure of the system, from the microscopic scale down to the intermolecular level. Confocal microscopy was used to provide direct-space visualization of lecithin vesicles at the micrometer range. Information on sizes and polydispersity of vesicles in the bulk of the solutions was obtained from dynamic light scattering (DLS) assays, whereas data on local membrane structure was probed through small-angle $\mathrm{X}$-ray scattering. Intermolecular interactions regarding adsorption of peptides onto lipid membranes were assessed by infrared and circular dichroism spectroscopies.

A multi-to-unilamellar transition was observed induced upon peptide concentration, indicating that the delicate balance between attractive and repulsive interactions in the multilamellar structure is affected by the incorporation of peptides. From the experimental results, we discuss possible mechanisms leading to this transition.

\section{MATERIAL AND METHODS}

Soy lecithin (Avanti Polar) is a mixture of phosphatidylcholines whose major constituent is dilinoleoylphosphatidylcholine (DLPC). The molar mass of the mixture is $\mathrm{M}_{\mathrm{w}}=776 \mathrm{~g}$ and specific mass is $1.01 \mathrm{~g} / \mathrm{cm}^{3}$. The diphenylalanine sequence (FF) was purchased from BachemSwitzerland $\left(\mathrm{M}_{\mathrm{w}}=312.4 \mathrm{~g} \cdot \mathrm{mol}^{-1}\right)$ and used without further purification. The peptide sequence $\mathrm{NH}_{2}$-Cys-Phe-Phe- $\mathrm{CO}_{2} \mathrm{H}$ (CFF) was synthesized through the solid phase Fmoc strategy as described elsewhere. ${ }^{30}$ For this, $0.65 \mathrm{~g}$ of Fmoc-F-OH $(1.7 \mathrm{mmol})$ and $0.98 \mathrm{~g}$ of Fmoc-C(Trt)-OH $(1.7 \mathrm{mmol})$ were used. $\mathrm{N} \alpha$-terminus was removed by reaction with $20 \%$ piperidine in dimethylformamide for $30 \mathrm{~min}$ and washed with methanol and dichloromethane. The couplings 
were made with N,N'-diisopropylcarbodiimide (0.42 g, $3.4 \mathrm{mmol})$, N-methyl-2-pyrrolidone (10 g, $0.10 \mathrm{mmol})$ and 1-hydroxybenzotriazole $(0.45 \mathrm{~g}, 3.4 \mathrm{mmol})$ for $4 \mathrm{~h}$ and monitored by the ninhydrin test (Kaiser). The cleavage mixture used for the removal of the Fmoc-F-Wang resin (100-200 mesh, with substitution degree of $0.67 \mathrm{mmol} \mathrm{g}^{-1}$ ) and the protecting groups present comprised: 94\% trifluoroacetic acid, 2.5\% dithiothreitol, 1.0\% triisopropylsilyl hydrochloride and 2.5\% water. Electrospray ionization mass spectroscopy (ESI-MS) was used for assessing the molar mass. CFF: (ESI-MS), T: $40^{\circ} \mathrm{C}$, (0.1\% trifluoroacetic acid/acetonitrile:water), $\mathrm{C}_{21} \mathrm{H}_{25} \mathrm{~N}_{3} \mathrm{O}_{4} \mathrm{~S}[\mathrm{M}+\mathrm{H}]+$ : calculated $414.5 \mathrm{~g} \mathrm{~mol}^{-1}$, found $415.5 \mathrm{~g} \mathrm{~mol}^{-1}$.

The protocol for preparing the samples is described in the following. Soy lecithin and peptides were cosolubilised into 1:1 (v:v) chloroform/methanol mixtures. The peptide/lipid molar ratio $(\mathrm{P} / \mathrm{L})$ was varied from 0 up to 0.2 and the solution was kept under stirring at room temperature for homogenization. Organic solvents were evaporated under vacuum for a period, varying from 3 to 7 days. Vesicles solutions for SAXS and DLS experiments were prepared by resuspending dry films at room temperature in miliQ water (> $18 \mathrm{M} \Omega$ ), at final volume percent concentration of $1 \%$. After a period of $4 \mathrm{~h}$ in rest, the mixtures were submitted to ultrasonication for about one hour to ensure homogenization. Samples were submitted to cycles of agitation at room temperature followed of stocking in refrigerator $\left(4^{\circ} \mathrm{C}\right)$. This procedure was repeated at least about 10 times.

Fourier transform infrared spectroscopy (FTIR) assays were carried out on a Varian 660IR spectrometer at the multiuser platform of the Federal University of ABC (CEM/UFABC). The device was operated in ATR mode and spectra were collected with step resolution of $2 \mathrm{~cm}^{-1}$. Samples for FTIR experiments were prepared using the same dried films described above; however, more concentrated solutions (i.e., containing lipids at volume percent concentration of about $40 \%$ ) were used to provide suitable signal-to-noise ratios. As further confirmed by SAXS data, these samples containing $\mathrm{H}_{2} \mathrm{O}$ at volume fraction of $60 \%$ are above the dilution limit of the lamellar phases formed by these lipids. ${ }^{31,32}$ Droplets of concentrated peptide/lipid mixtures at different $\mathrm{P} / \mathrm{L}$ ratios were placed onto the $\mathrm{ZnSe}$ ATR crystal and one hundred accumulations were obtained across two wavenumber intervals: $700-1800 \mathrm{~cm}^{-1}$, where vibrations associated to phosphate and choline groups appear in lecithin spectra, ${ }^{33}$ and $2800-3050 \mathrm{~cm}^{-1}$, which is related to vibrations from alkyl groups of hydrophobic tails. ${ }^{33}$ Spectra were averaged and background subtracted; resonances were deconvoluted and fitted to Gaussian profiles using the program Fityle to enable accurate assignment. 
Dynamic light scattering (DLS) experiments were performed on Brookhaven 90 Plus equipment. Size distributions of vesicles were obtained from the fitting of self-correlation functions, considering sphere approximation for the particles.

Optical observations were carried out on a Leica TCS SP8 confocal microscope. Droplets from solutions containing peptide-doped lipid vesicles were placed onto glass slides and quickly sandwiched with cover slips. The instrument operated in differential contrast mode (DIC) and samples were kept unstained in order to avoid interference of fluorophore in the interplay between peptides and membranes. To prevent evaporation during the imaging procedure, the set was sealed with nail polish. Images were collected using phase contrast mode, with a $40 \times$ dry objective opera and a pinhole aperture at 1 Airy unit to provide shallow depth of field and remove out-of-focus glare. Image treatment and enhancement was performed with LAS X software, available from the microscope manufacturer.

Circular Dichroism (CD) assays were carried out on a JASCO 810 operating at $22^{\circ} \mathrm{C}$, with the instrument kept under $\mathrm{N}_{2}$ saturation during the measurements. Droplets from peptide/lecithin solutions were sandwiched in-between quartz windows of demountable Hellma cells with pathlengths of $0.1 \mathrm{~mm}$ or $1 \mathrm{~mm}$, depending on concentration. Scans were recorded across the wavelength range $190-260 \mathrm{~nm}$, with steps of $0.5 \mathrm{~nm}$, speed of $20 \mathrm{~nm} / \mathrm{min}$ and bandwidth of 1 $\mathrm{nm}$. Four accumulations were averaged and background subtracted, and photomultiplier voltage was kept below $500 \mathrm{~V}$ throughout the measured range in order to ensure proper absorbance levels. Data were normalized by peptide concentration and cell pathlength to enable comparison between different formulations.

X-ray scattering was performed on solutions loaded into glass capillaries on a XeussXenocs instrument at the Institute of Physics of the University of São Paulo. The detector was a Pilatus $300 \mathrm{~K}$ (Dectris), with pixel size of $172 \times 172 \mu \mathrm{m}$. The radiation produced by the microfocus copper source was collected with a single reflection multilayer optics producing a low-divergence monochromatic beam with wavelength $\lambda=0.154 \mathrm{~nm}$. The beam was is further collimated by a pair of scatterless slits with upstream slits of $0.6 \times 0.6 \mathrm{~mm}$, downstream slits with $0.5 \times 0.5 \mathrm{~mm}$. The sample-to-detector distance, calibrated with a Silver Behenate standard, was $0.85 \mathrm{~m}$. The scattering vector (q) spanned from $0.04 \mathrm{~nm}^{-1}$ to $3.5 \mathrm{~nm}^{-1}$. All scattering experiments were performed at room temperature. The integration of two-dimensional scattered intensity $\mathrm{I}(\mathrm{q})$ was performed with Foxtrot-Xenocs software and the files generated were processed with SUPERSAXS program ${ }^{34}$ that allows proper normalization and background subtraction.

Data analysis was carried using two different procedures. For samples providing sharp peaks associated to the presence of multi-lamellar vesicles, it was used a model of periodic stacked 
bilayers as previously described. ${ }^{35,36}$ The model allows for simultaneous determination of major structural features such as lamellar periodicity, bilayer thickness and number of correlated bilayers. Also, it provides the electronic contrast profile of the bilayers and the Caille parameter, $\eta=$ $q_{0}^{2} k T / 8 \pi \sqrt{K B}$. This parameter characterizes the elasticity of the lamellar structure, where $\mathrm{K}$ is the curvature modulus and B the compressibility modulus. Scattering profiles from samples associated to unilamellar vesicles exhibited only diffuse bands and Bragg peaks were not observed. In this case, analysis was performed using the indirect Fourier Transform method to obtain the pair distance distribution function $\mathrm{p}(\mathrm{r}),{ }^{37}$ where $r$ is the distance between points within scattering objects in the solution.

\section{EXPERIMENTAL RESULTS}

To investigate the effects of FF and CFF sequences on the structure of model lecithin vesicles, we first collected FTIR spectra from formulations containing peptides and lipids at different $\mathrm{P} / \mathrm{L}$ ratios. The volume percent concentration of lipids in the samples was about $40 \%$ in order to reach proper signal-to-noise ratios. In Figure $1 \mathrm{a}$ and 1b, representative curves from these assays are shown to provide direct comparison between different samples. The peaks observed in FTIR spectra for pure lecithin are compatible with what has observed for other phospholipids and the vibration groups can be assigned as listed in Table 1 , for $\mathrm{P} / \mathrm{L}=0 .{ }^{33,38}$ The first evidence arising from the data is that vibrational behavior of $\mathrm{P} / \mathrm{L}$ samples is highly complex with spectra being characterized by heavily mixed bands, reflecting the diversity of chemical groups available in phosphatidylcholine membranes. ${ }^{38}$

The region comprised between 700 and $1800 \mathrm{~cm}^{-1}$ carries information on vibrations associated to phosphate and choline groups, ${ }^{39,40}$ which are presumably located closer to aqueous interfaces of membranes; whereas the range between 2800 and $3050 \mathrm{~cm}^{-1}$ contains data related to vibrations from alkyl moieties present in the hydrophobic core of bilayers. ${ }^{38,41}$ Interestingly, peaks in the region associated to alkyl chains are not affected by peptide addition (see upper plots in Figure 1) suggesting that both FF and CFF are not embedded in the hydrophobic part of membranes. On the other hand, peaks related to chemical groups in the vicinities of polar interfaces show appreciable variations when peptide are introduced in the mixture evidencing that peptide/lipid interplay is rather correlated to interfacial interactions. 


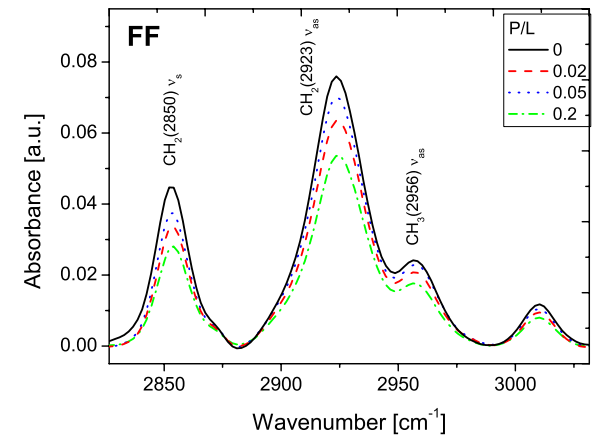

(a)

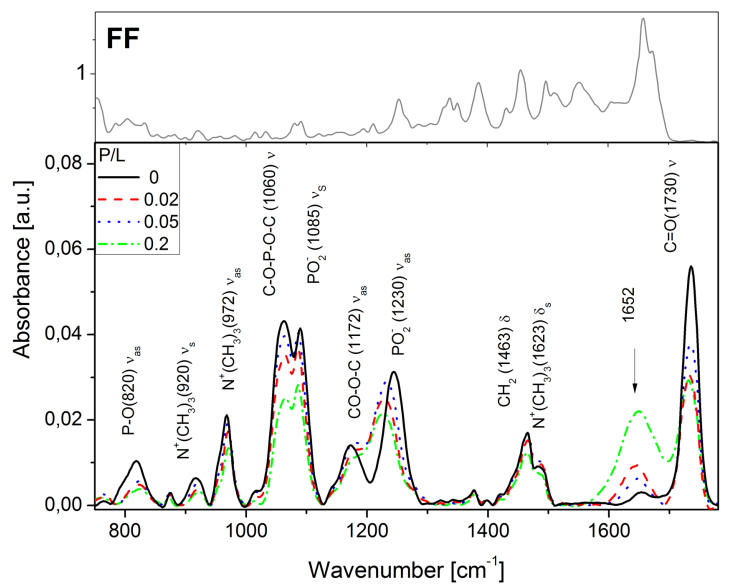

(c)

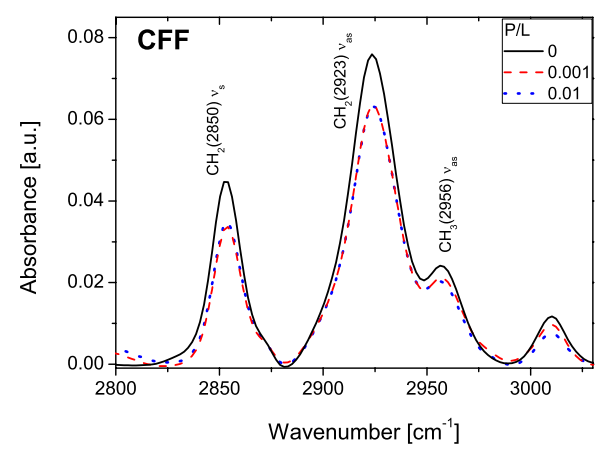

(b)

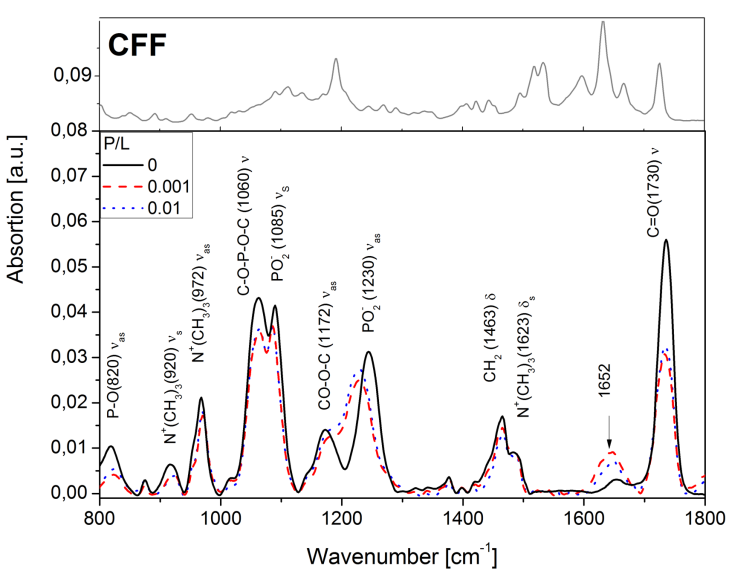

(d)

Figure 1. FTIR spectra from peptide/lipid formulations prepared at different P/L ratios. (a) and (b) Data from 2800-3050 $\mathrm{cm}^{-1}$ range, regarding vibrations from alkyl chains composing the hydrophobic core of the membranes. (c) and (d) Data from the range between 800 and $1800 \mathrm{~cm}^{-1}$, carrying information on phosphate and choline groups located close to the aqueous interface for different $\mathrm{P} / \mathrm{L}$ ratios. At the top, in gray, spectra from samples containing only peptides (without lipids) are shown for comparison.

Table 1. Summary of main vibrations regarding phosphate and choline groups. Wavenumber values are given in $\mathrm{cm}^{-1}$ and the chemical groups associated to the vibrations are shown in the left column.

\begin{tabular}{|c|c|c|c|c|c|c|}
\cline { 2 - 7 } \multicolumn{1}{c|}{} & Lecithin & \multicolumn{2}{|c|}{ FF/Lecithin } & \multicolumn{2}{c|}{ CFF/Lecithin } \\
\hline Vibration & $\mathbf{0}$ & $\mathbf{0 . 0 2}$ & $\mathbf{0 . 0 5}$ & $\mathbf{0 . 2}$ & $\mathbf{0 . 0 0 1}$ & $\mathbf{0 . 0 1}$ \\
\hline $\mathbf{P}-\mathbf{O}_{\text {vas }}$ & 819 & 823 & 824 & 824 & 823 & 823 \\
\hline $\mathbf{N}^{+}\left(\mathbf{C H}_{\mathbf{3}}\right)_{\text {vs }}$ & 916 & 921 & 923 & 923 & 922 & 923 \\
\hline
\end{tabular}




\begin{tabular}{|c|c|c|c|c|c|c|}
\hline $\mathbf{N}^{+}\left(\mathrm{CH}_{3}\right)_{3}$ vas & 967 & 969 & 970 & 971 & 970 & 970 \\
\hline C-O-P-O-C ${ }_{v}$ & 1062 & 1064 & 1064 & 1065 & 1063 & 1063 \\
\hline $\mathrm{PO}_{2 \text { vs }}$ & 1090 & 1085 & 1086 & 1085 & 1086 & 1086 \\
\hline CO-O-C vas & 1172 & 1179 & 1180 & 1179 & 1176 & 1179 \\
\hline $\mathrm{PO}_{2 \text { vas }}$ & 1244 & 1232 & 1229 & 1226 & 1229 & 1229 \\
\hline $\mathrm{CH}_{2 \delta}$ & 1466 & 1466 & 1465 & 1465 & 1466 & 1466 \\
\hline $\mathrm{C}=\mathrm{O}_{\mathrm{v}}$ & 1735 & 1734 & 1732 & 1731 & 1733 & 1733 \\
\hline
\end{tabular}

In despite the complexity of the vibration profile makes difficulty accurate description on a quantitative basis, valuable information about peptide/lipid interactions could be obtained from qualitative analyses performed from noticeable shifts of bands related to these interfacial groups. The peak positions of main vibrations appearing in FTIR spectra are summarized in Table I for the different formulations. Since no significant information from either water molecules or peptide species are present at spectral region comprised between 750 and $900 \mathrm{~cm}^{-1}$, we first focused our attention at phosphate vibrations appearing at this range. ${ }^{40}$ Particularly, vibration associated to P$\mathrm{O}$ asymmetric stretching, P-O $\mathrm{vas}_{\text {as }}$, is strongly affected by addition of peptides to the lipid matrix. In fact, in preparations containing only the lipid component, the $\mathrm{P}-\mathrm{O}_{\mathrm{vas}}$ band is found at $819 \mathrm{~cm}^{-1}$. Upon addition of FF, this peak is shifted to $824 \mathrm{~cm}^{-1}$, indicating growth of bonding energy. In the case of CFF-containing formulations, shifts are observable when much smaller peptide amounts are added to the lipid phase, suggesting that interaction between this peptide and lecithin is still stronger.

In addition to characteristic phosphate/choline bands, the $700-1800 \mathrm{~cm}^{-1}$ range exhibits a strong vibration at $1652 \mathrm{~cm}^{-1}$, which is correlated to increase of disordered content in peptide aggregates appearing in the medium. Intensity variations observed in characteristic peaks at 2850, 2922 and $2958 \mathrm{~cm}^{-1}$, are likely related to changes in the texture of lipid/peptide solutions for the different $\mathrm{P} / \mathrm{L}$ ratios and do not account for peptide influence on interacting alkyl chains.

These findings suggest charge delocalization from phosphate groups at lecithin polar heads toward peptide moieties. Specifically, they are indication for the formation of H-bonds between oxygen atoms at phosphate units and peptides. In the case of FF species, H-bonding presumably occurs between phosphate oxygen and amide (or carboxyl) termini at peptide backbone. In the case of CFF, sulfur atoms at cysteine side-chains could also assist H-bonding, explaining the stronger interaction observed when this peptide is introduced in the formulation. Another consequence of the presence of peptides in the membranes is the broadening of characteristic 
resonances associated to phosphate moieties. Indeed, enlargement of peaks correlated to both $\mathrm{P}-\mathrm{O}_{\text {vas }}\left(\right.$ ca. $\left.820 \mathrm{~cm}^{-1}\right)$ and $\mathrm{PO}_{2}^{-}$vas $\left(c a .1230 \mathrm{~cm}^{-1}\right)$ asymmetric stretching is clearly observed upon peptide addition (see Figure 1). In the case of $\mathrm{PO}_{2}{ }^{-}$vas, displacement to lower wavenumbers induces overlap with $\mathrm{CO}-\mathrm{O}-\mathrm{C}_{\text {vas }}(\mathrm{ca} .1172 \mathrm{~cm}-1)$. The proper interpretation of such overlapping is more complex since this region also carries information on angular deformations of $\mathrm{H}_{2} \mathrm{O}$ molecules; ${ }^{42}$ however, such an appreciable shift upon peptide addition not only indicate that peptide/lecithin interaction mainly occurs at phosphate groups but also suggests that solvation could be affect by peptides with appearance of water combination bands. ${ }^{43}$ In addition to phosphate groups, shifts are also observed in vibrations associated to choline groups, where frequencies related to $\mathrm{N}^{+}\left(\mathrm{CH}_{3}\right)_{3}$ assignments are found to shift from $916 \mathrm{~cm}^{-1}$ to about $923 \mathrm{~cm}^{-1}$, in the case of asymmetric stretching, and from $967 \mathrm{~cm}^{-1}$ to about $971 \mathrm{~cm}^{-1}$ in the case of symmetric stretching.

From DLS experiments, we evaluated the effect of the two sequences on vesicle dimension. In Figure $2 \mathrm{a}$, it is shown the average radius of the vesicles as a function of the $\mathrm{P} / \mathrm{L}$ ratio used in the preparation. Overall, the data reveal that incorporation of peptides into the lipid phase increases the hydrodynamic radius $\left(\mathrm{R}_{\mathrm{h}}\right)$ of resulting vesicles, although a small fraction of particles remains with the same size of peptide-free formulations. The action of both peptides on $\mathrm{R}_{\mathrm{h}}$ is quite similar for $\mathrm{P} / \mathrm{L}$ ratios up to 0.05 ; however, at higher ratios, the difference between them becomes more evident (Figure $2 \mathrm{~b}$ ). The CFF sequence induces a faster growing of vesicle dimension, leading to structures about 10 times larger than vesicles with FF sequence in the membrane. For large $\mathrm{P} / \mathrm{L}$ ratios, the vesicles become large enough to be observed in microscopy as shown in Figure 3, for $\mathrm{P} / \mathrm{L}=0.2$. Measurements on the diameter of the vesicles observed in confocal images reveal characteristic sizes of the order of a few micrometers, consistent with hydrodynamic radius $\left(\mathrm{R}_{\mathrm{h}}\right)$ found in DLS experiments.

$\mathrm{X}$-ray experiments also present distinct features depending on the amino acids sequence used in the formulation. In Figure $3 a$, it is shown scattering curves obtained from samples containing the peptide FF. One observes that the patterns are characterized by a collection of equally spaced Bragg peaks, indicating the formation of periodic structures with repeat distance of about $64 \AA$ associated to multi-lamellar vesicles in solution. In despite the lamellar behavior is clearly preserved up to $\mathrm{P} / \mathrm{L}=0.1$, as evidenced by Bragg peaks associated to the same periodicity found in peptide-free formulations, the relative intensities between the first and second orders show strong changes upon peptide concentration. Particularly, as the FF amount increases, Bragg peaks vanish indicating loss of order in the lamellar phase. This effect may be attributed either to changes of the bilayer form factor or elasticity of the lamellar structure ${ }^{36,44}$, or both. 


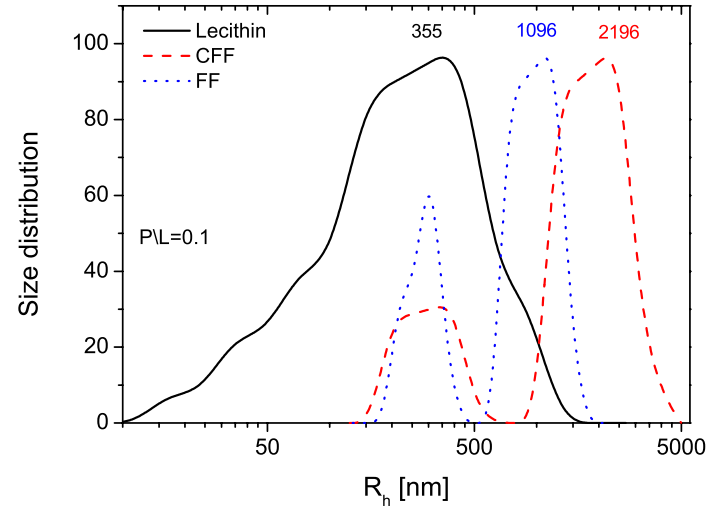

(a)

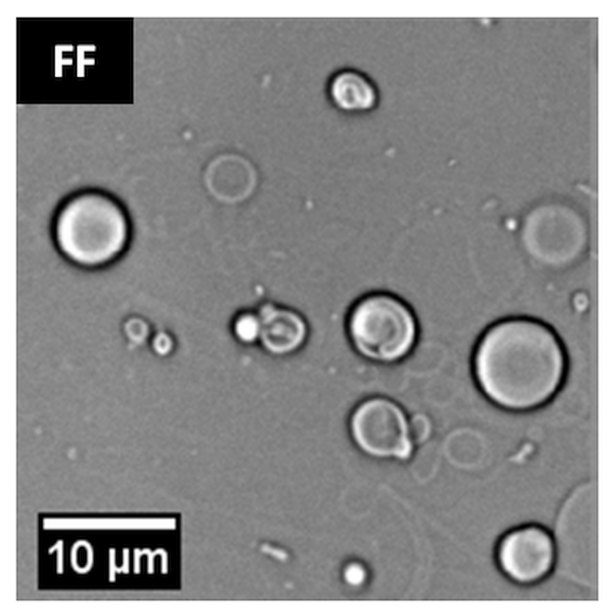

(c)

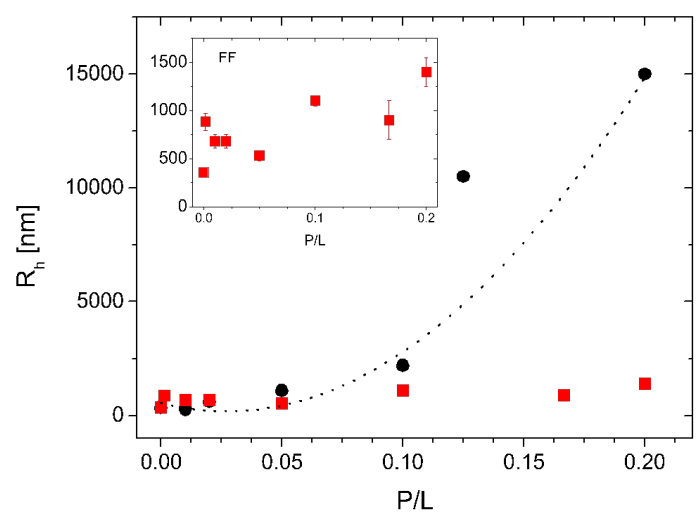

(b)

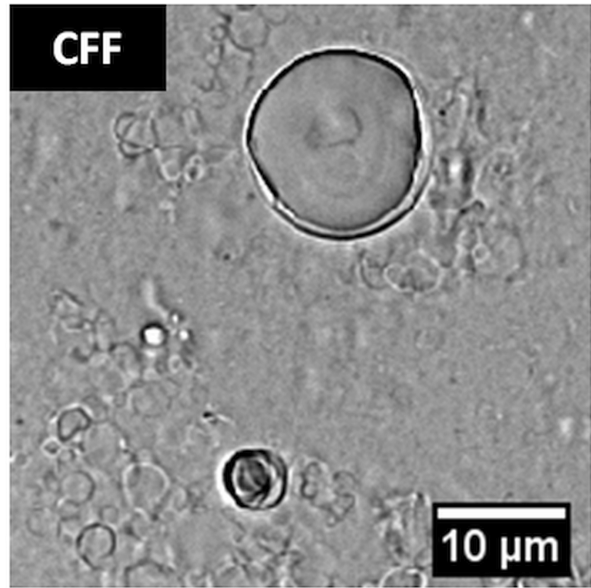

Figure 2: (a) Size distribution of vesicles revealed by DLS. Solid line represents a formulation containing only lecithin $(\mathrm{P} / \mathrm{L}=0)$ whereas dotted and dashed lines indicate samples containing, respectively, $\mathrm{FF}$ and $\mathrm{CFF}$ at $\mathrm{P} / \mathrm{L}=0.1$. (b) Concentration series showing the effect of $\mathrm{FF}$ and $\mathrm{CFF}$ peptides on the hydrodynamic radius of vesicles. Uncertainty of each measurement is comparable to the size of symbols and the dashed line is only a guide to eyes. (c)Micrographs from vesicles prepared with $\mathrm{P} / \mathrm{L}=0.2$. 

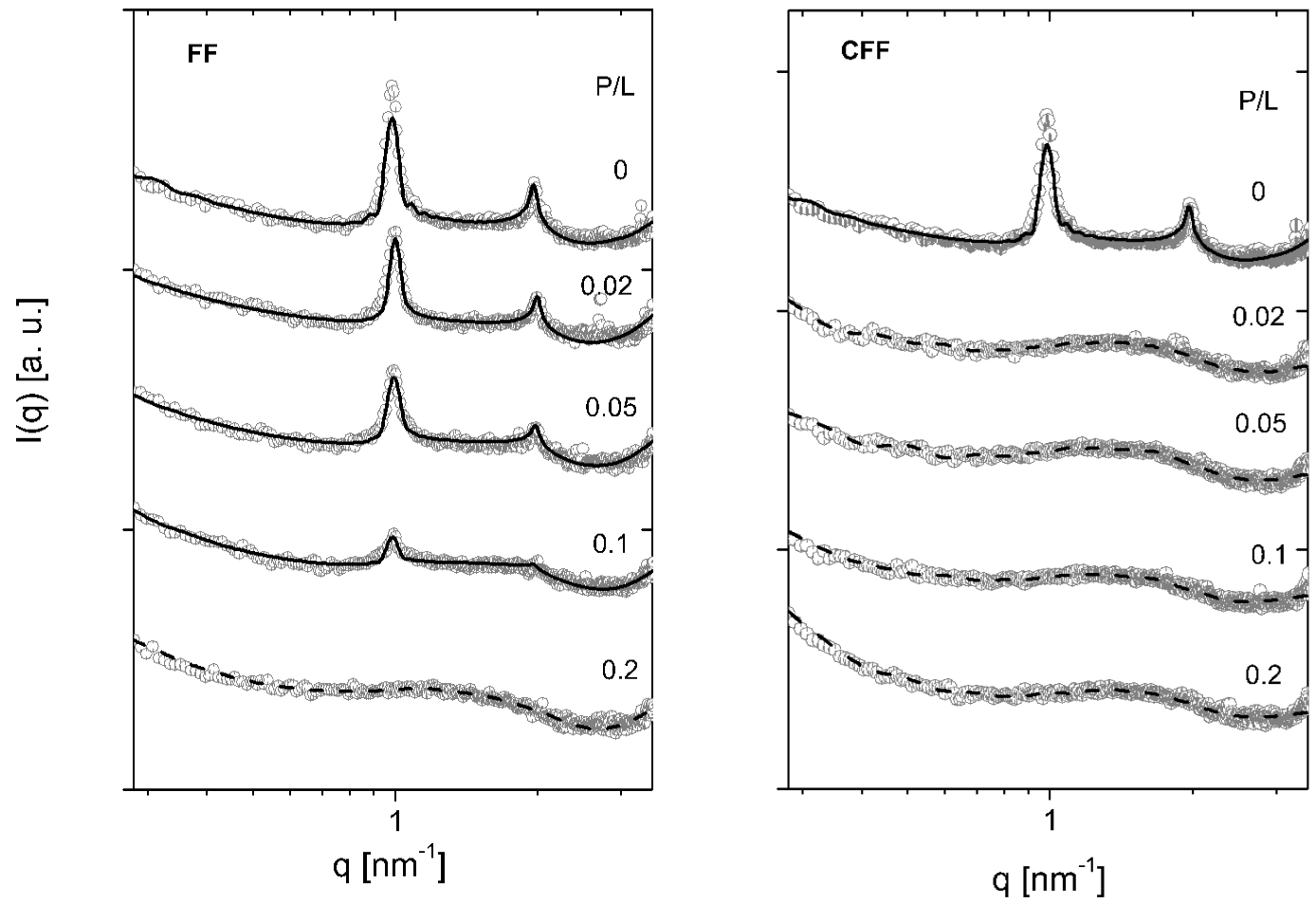

Figure 3(a): X-ray scattering curves obtained varying the molar ratio of peptide/lipid (P/L) from 0 to 0.2 for FF and CFF sequences and the number above each curve denotes the ratio P/L. The solid lines represent the fitting to the experimental data, considering a periodic stacking of bilayers, and the dashed lines represent a fitting considering the scattering of spherical shells.

When the ratio $\mathrm{P} / \mathrm{L}$ is increased to 0.2 , correlations between bilayers are no longer visible and only a diffuse and broad peak is observed. Applying the indirect Fourier Transform Method, we obtained the pair distance distribution function $\mathrm{p}(\mathrm{r})$ (Figure 4) compatible with the scattering of core-shell particles, or unilamellar vesicles. Therefore, there is a critical concentration of FF in the membrane that induces a transition from multilamellar to unilamellar vesicles.

In the case of the CFF peptide, destruction of the lamellar structure and appearance of unilamellar vesicles are still more evident. In fact, in Figure 3b, one observes that minimal amounts of CFF are enough to vanish the Bragg peaks appearing in lecithin vesicles. The dashed lines represent the fitting of the experimental data that is consistent with spherical shells in the solution.

Figure 4 shows the plot of the pair distance distribution function $p(r)$ obtained from the Inverse Fourier Transform Method, applied to the scattering curves with a broad peak of vesicles containing FF $(\mathrm{P} / \mathrm{L}=0.2)$ and $\mathrm{CFF}$. The shape of the $p(r)$ curves is consistent with a model of unilamellar vesicles, with the first peak corresponding to the polar region of the bilayer, with a 
positive contrast with respect to the solvent, and a negative region representing the hydrophobic part.

It is important to note that pair distance distribution function is not a direct measure of the vesicle diameter or a quantity related to the whole vesicle; instead, it provides the distribution function of the local structure at the bilayers. The membrane thickness can be estimated considering the value of $r$ for which the function returns to the same positive value of the peak, as illustrated in the inset by the vertical lines for two concentrations of peptide. The membrane thickness for low amount of CFF peptide is drastically reduced from $4 \mathrm{~nm}$ to less than $3 \mathrm{~nm}$, for $\mathrm{P} / \mathrm{L}=0.2$, and the negative part of the function disappears. For this particular amino acids sequence the interactions between cysteine group and phosphate group foster changes at bilayer interface. The oscillation of the $p(r)$ provides only qualitative information about the diameter of vesicles and indicates the tendency of increasing diameter with increasing peptide concentration, which is supported by DLS measurements.

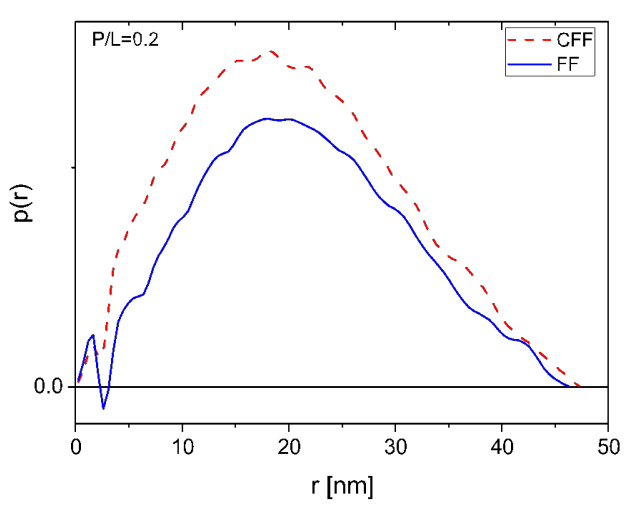

(a)

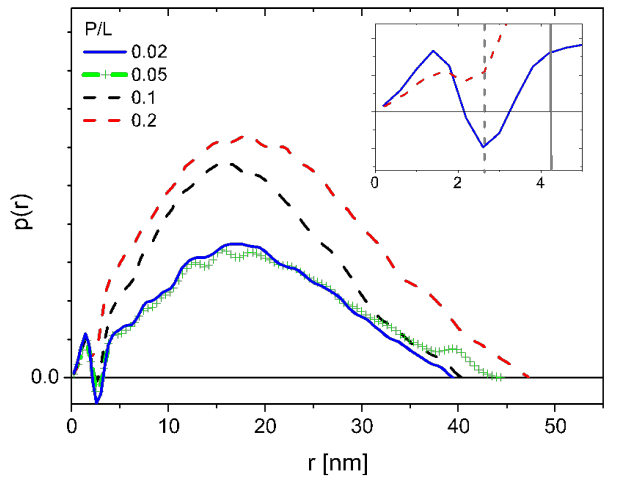

(b)

Figure 4: (a) Plot of Pair distance distribution function (in arbitraty units) obtained for lipid membranes containing $\mathrm{FF}$ and $\mathrm{CFF}$, for $\mathrm{P} / \mathrm{L}=0.2$. (b) Effect of $\mathrm{CFF}$ concentration on $(p(r))$. In the inset, for low values of $r$, it is possible to identify the change in electronic contrast corresponding to the interface bilayer-water for two concentrations of CFF. The vertical lines are used to estimate the bilayer thickness.

Although the multilamellar period does not change with incorporation of $\mathrm{FF}$, major changes occur in the bilayer form factor, as evidenced by changes in structural parameters and the Caillé parameter, illustrated in Figure 5. The membrane thickness $\left(\delta_{\mathrm{m}}\right),{ }^{35}$ jumps from $3.8 \mathrm{~nm}$ to 4.4 $\mathrm{nm}$ for just a small amount of peptide, $\mathrm{P} / \mathrm{L}=0.002$ (see Figure 5). Then, with further increasing on $\mathrm{P} / \mathrm{L}$ ratio, $\delta_{\mathrm{m}}$ decreases and increases again, remaining slightly thicker than a pure lecithin bilayer. The behavior of the Caillé parameter, Figure 5b, indicates that the multilamellar structure gains a 
moderate elasticity upon addition of small amounts of peptide, which can be ascribed to local defects in the bilayers. Nevertheless, as the concentration of peptide increases, the structure becomes more rigid again. Since the lamellar period remains constant, the separation between membranes is reduced with the addition of peptides. It is interesting to note that the lower values of membrane thickness appear along with larger values of the Caillé parameter.

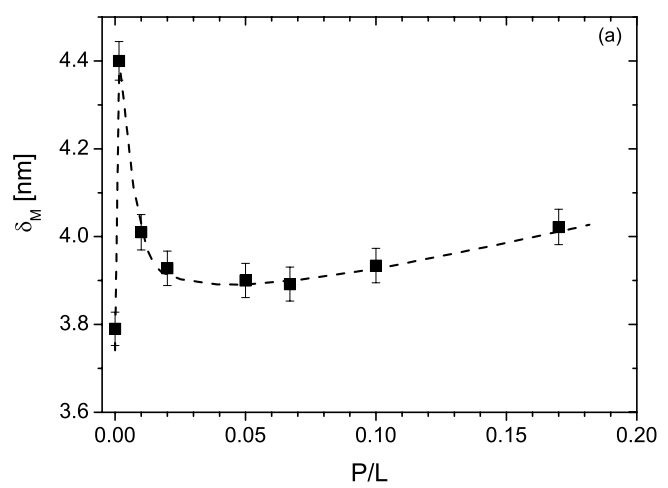

(a)
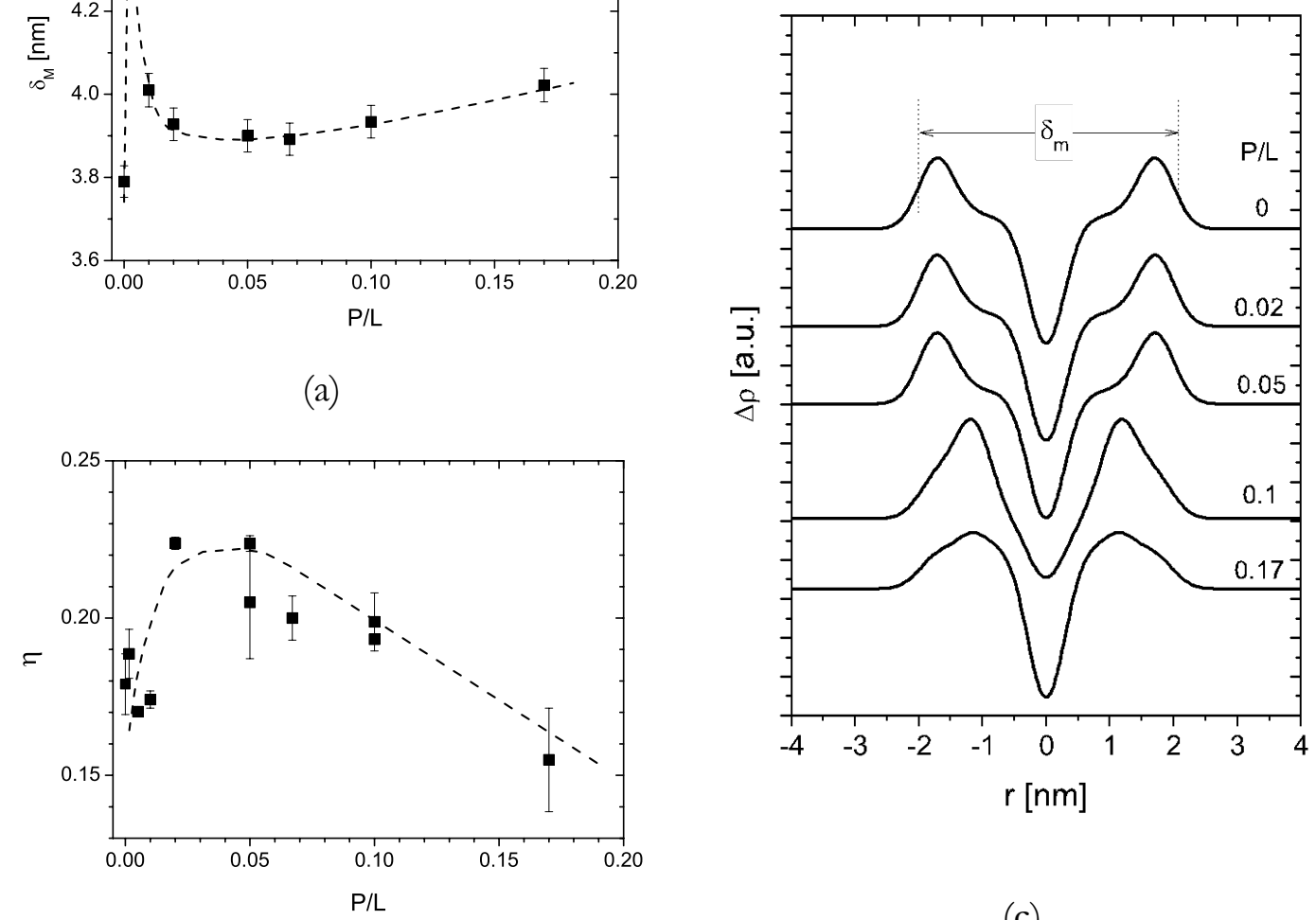

(c)

(b)

Figure 5: Structural parameters of lecithin vesicles as a function of FF content; membrane thickness $\left(\delta_{\mathrm{M}}\right)$, Caillé parameter $(\eta)$ and the electron density profile $(\Delta \rho)$. The dashed lines are only guides to the eyes.

The electron density profiles, shown in Figure $5 c$, indicate that the action of the peptide in the membrane mostly affects the interface with the water layers in between lipid membranes. In fact, broadening of Gaussians associated to the polar region is clearly observed for $\mathrm{P} / \mathrm{L} \approx 0.1$ and 0.2 , which could be ascribed to increasing disordering of phosphate groups induced by selfassociation of peptides. To check this hypothesis we examine in detail the SAXS curves, in a Guinier plot shown in Figure 6a. In this representation, the slope of the linear region is proportional to radius of gyration of scattering particles and it can be observed that it increases with increasing 
peptide concentration. There are two possible contributions to the increasing slope, the increasing dimension of the vesicles, observed by DLS experiments, and the aggregation of peptides. In Figure $6 \mathrm{~b}$, in addition to the contribution of the form factor of unilamellar spherical vesicles, a sharp peak at $3,2 \mathrm{~nm}^{-1}\left(2 \theta \approx 4.6^{\circ}\right)$ can be identified. This peak can be assigned to the formation of the crystalline structure of FF corresponding to orthorhombic symmetry, (space group H-M P21 21 21). ${ }^{45}$

The secondary structure of the peptide aggregates was probed by CD experiments, shown in Figure 6c, exhibiting characteristic signatures previously observed in FF nanotubes. ${ }^{46}$, ${ }^{47}$ The spectra are featured by a strong negative rotation placed at $192 \mathrm{~nm}$, followed by a positive shoulder at $202 \mathrm{~nm}$ which is assigned to $\pi \rightarrow \pi^{*}$ transitions. These features could be assigned to the formation of $\beta$-turn structures in FF aggregates, as assumed elsewhere. ${ }^{46,48} \mathrm{Also}$, the minimum at $192 \mathrm{~nm}$ could be ascribed to the presence of unordered content in FF aggregates formed in the solutions, ${ }^{49}$ which is consistent with the increment observed in the peak at $1652 \mathrm{~cm}^{-1}$ in FTIR spectra upon growth of the $\mathrm{P} / \mathrm{L}$ ratio. A noticeable maximum near to $218 \mathrm{~nm}$ is related to transitions in aromatic rings and is commonly found in $\mathrm{CD}$ spectra from phenylalanine-rich species. ${ }^{50} \mathrm{The}$ growth of the peak at $202 \mathrm{~nm}$ upon increase of the $\mathrm{P} / \mathrm{L}$ ratio suggests the formation of ordered assemblies as the amount of FF in the formulation raises. Furthermore, it is consistent with the involvement of peptide aggregates in the multi-to-unilamellar transition of the lecithin vesicles and corroborates with the formation of $\beta$-structures ${ }^{51}$ and oligomerization of amyloid peptide binding to lipid membranes. ${ }^{52,53,54}$ Interestingly, these findings associated to the SAXS information presented above indicate that even the minimalist $\mathrm{A} \beta(1-42)$ core-recognition motif is able to self-assemble onto biomembrane interfaces and affect the elastic properties producing strong supramolecular repercussions such as the multi-to-unilamellar transition observed in our vesicles.

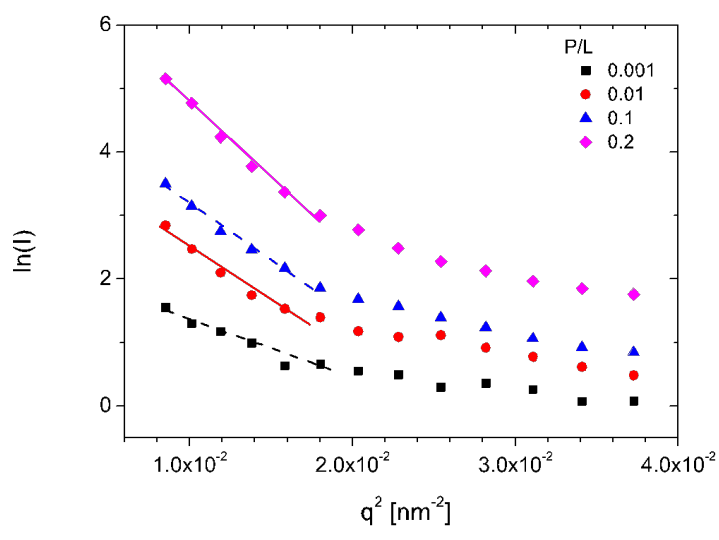

(a)

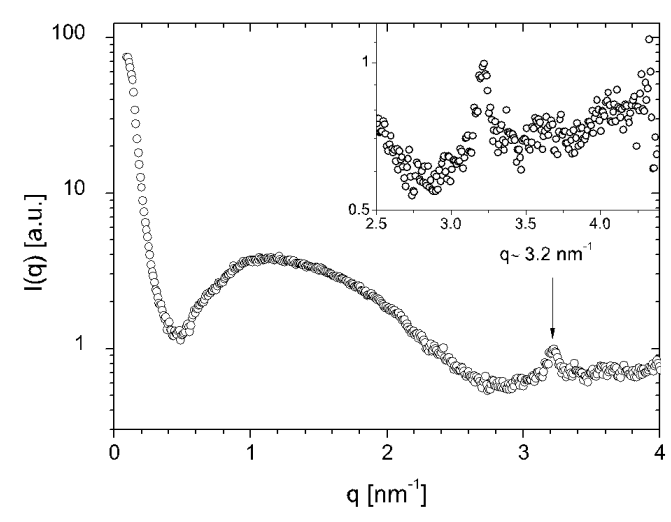

(b) 


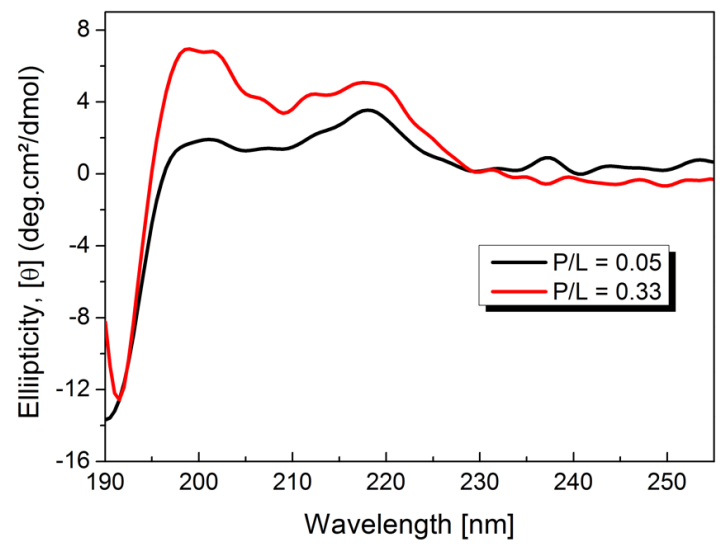

(c)

Figure 6: (a) The increasing slope of the SAXS in the Guinier region indicates the formation of aggregates for increasing $\mathrm{P} / \mathrm{L}$ ratios. The dashed lines are only guides to the eyes. (b) SAXS curve for $\mathrm{P} / \mathrm{L}=0.2$. The arrow indicates the peak at $3.2 \mathrm{~nm}^{-1}$ that corresponds to the crystalline structure of the FF and is shown in detail in the inset. (c) CD spectra for two samples with different $\mathrm{P} / \mathrm{L}$ ratios.

\section{DISCUSSION AND CONCLUSIONS}

FTIR data showed that peptides are located at the interface of the membranes, as attested by the strong influence that the amino acid sequences have on the vibrational behavior of phosphate groups. Particularly, the interplay is mediated by hydrogen bonding, which likely occurs between phosphate oxygen and amide and carboxyl groups at peptide backbones. In the case of the tripeptide CFF, the sulfur atom at cysteine side-chain likely assist H-bond donation, corroborating the stronger influence of this peptide in the phosphate vibrations. Also, this finding is consistent with the higher ability of CFF for promoting multilamellar-to-unilamellar transition. In fact, since CFF is more efficient for membrane adhesion through its increased H-bond donating capabilities, the organization of this peptide onto membrane surface quickly leads to decrease of local entropy. In this case, a corresponding translational entropy gain should be associated to release of water molecules from the vicinities of the interface.

This picture is consistent with both SAXS and DLS data, which show not only destruction of lamellar order, but also increase of vesicle diameter upon peptide addition. Also, the diminution observed in the Caillé parameter when peptides are added to the mixtures could be a consequence of ordering growth at membrane interfaces, which should be accompanied by water release from aqueous gaps in order to thermodynamically favor self-assembly. Finally, it is observed that the fluid nature of the lamellar structure is preserved even for high amount of peptide for which aggregation is already present. 
The results presented above suggest that the action of peptides on membrane structure follows different steps across the range of $\mathrm{P} / \mathrm{L}$ ratios investigated. For instance, SAXS data revealed that membrane thickness exhibits slight growth when small amounts of peptides are embedded in the lipid phase. This finding is consistent with peptide molecules adhering to membrane surfaces and corroborates with FTIR experiments that revealed interactions between peptides and phosphate groups closer to aqueous interfaces mostly mediate membranes. This process is accompanied by moderate increasing on the flexibility of the structure.

The second step takes place for $\mathrm{P} / \mathrm{L}>0.05$; and can be associated to the tendency of Caillé parameter to decrease and the slight increasing of membrane thickness. As the lamellar structure becomes stiffer, the vesicle diameter has to increase. The relative intensity of first and second order peaks in the scattering curves may be related to a reduction in the number of bilayers in the vesicles.

The self-association of peptides in more complex structures has been demonstrated both by the X-ray scattering and CD experiments. The formation of more complex structures may be responsible for increasing repulsive interactions between bilayers destabilizing the multilamellar structure, which would be the third step. It seems that the mulitlamellar-to-unilamellar transition is driven by the formation of peptide aggregates, and possibly mediated by direct peptide-peptide interactions in the bilayer interface. Indeed, the assembly and disassembly of diphenylalanine plays a major role in lipids organization. ${ }^{19}$

In the case of CFF sequences, the interactions with phosphate groups are enhanced by the cysteine side-chains. Thus, changes introduced by this peptide at the interfaces are more drastic and even small amounts leads to unilamellar vesicles. Therefore, we conclude that the effect of CFF on membranes leads directly to the final step discussed above.

The interpretation presented above is a tentative effort to describe our experimental results. Details of each step are still lacking and require more investigation that could eventually be supported by molecular dynamic simulations.

\section{Acknowledgments}

B.M.S. is grateful to CAPES for a doctoral fellowship. E.R.S. and W.A.A. acknowledge FAPESP for financial support (grant no 2016/24409-3 and 2015/24018-1). E.R.S. acknowledges CNPq for a fellowship (Proc. No 307017/2016-8). Dr. Sergio Kogikoski Jr. is kindly acknowledged for collecting FTIR data. D. Reis is acknowledged for assistance during SAXS assays. The multiuser microscopy laboratory at the National Institute of Pharmacology and Molecular Biology (INFAR- 
UNIFESP) is acknowledged for providing access to the Leica TCS SP8 microscope, under CAPES and FAPESP funding.

\section{REFERENCES}

1. SINGER, S.; NICOLSON, G. The Fluid Mosaic Model of the Structure of Cell Membranes. Science 1972, 175 (4023), 720-+.

2. ISRAELACHVILI, J. REFINEMENT OF FLUID-MOSAIC MODEL OF MEMBRANE STRUCTURE. Biochimica Et Biophysica Acta 1977, 469 (2), 221-225.

3. Murray, S.; O'Brien, R.; Mattson, K.; Ceccarelli, C.; Sykora, R.; West, K.; Davis, J. The Fluid-Mosaic Model, Homeoviscous Adaptation, and Ionic Liquids: Dramatic Lowering of the Melting Point by Side-Chain Unsaturation. Angewandte Chemie-International Edition 2010, 49 (15), 2755-2758.

4. Goni, F. The basic structure and dynamics of cell membranes: An update of the SingerNicolson model. Biochimica Et Biophysica Acta-Biomembranes 2014, 1838 (6), 1467-1476.

5. Papo, N.; Shai, Y. Can we predict biological activity of antimicrobial peptides from their interactions with model phospholipid membranes? Peptides 2003, 24 (11), 1693-1703.

6. Schmidtchen, A.; Ringstad, L.; Kasetty, G.; Mizuno, H.; Rutland, M. W.; Malmsten, M. Membrane selectivity by W-tagging of antimicrobial peptides. Biochimica et Biophysica Acta (BBA) Biomembranes 2011, 1808 (4), 1081-1091.

7. Moniruzzaman, M.; Islam, M. Z.; Sharmin, S.; Dohra, H.; Yamazaki, M. Entry of a SixResidue Antimicrobial Peptide Derived from Lactoferricin B into Single Vesicles and Escherichia coli Cells without Damaging their Membranes. Biochemistry 2017, 56 (33), 4419-4431.

8. Wang, K. F.; Nagarajan, R.; Camesano, T. A. Differentiating antimicrobial peptides interacting with lipid bilayer: Molecular signatures derived from quartz crystal microbalance with dissipation monitoring. Biophysical Chemistry 2015, 196, 53-67.

9. Pott, T.; Gerbeaud, C.; Barbier, N.; Meleard, P. Melittin modifies bending elasticity in an unexpected way. Chem Phys Lipids 2015, 185, 99-108.

10. Malanovic, N.; Leber, R.; Schmuck, M.; Kriechbaum, M.; Cordfunke, R. A.; Drijfhout, J. W.; de Breij, A.; Nibbering, P. H.; Kolb, D.; Lohner, K. Phospholipid-driven differences determine the action of the synthetic antimicrobial peptide OP-145 on Gram-positive bacterial and mammalian membrane model systems. Bba-Biomembranes 2015, 1848 (10), 2437-2447.

11. Dehsorkhi, A.; Castelletto, V.; Hamley, I. W.; Seitsonen, J.; Ruokolainen, J. Interaction between a cationic surfactant-like peptide and lipid vesicles and its relationship to antimicrobial activity. Langmuir 2013, 29 (46), 14246-53.

12. Pan, J.; Tieleman, D. P.; Nagle, J. F.; Kučerka, N.; Tristram-Nagle, S. Alamethicin in lipid bilayers: Combined use of X-ray scattering and MD simulations. Biochimica et Biophysica Acta (BBA) - Biomembranes 2009, 1788 (6), 1387-1397.

13. Hristova, K.; Dempsey, C. E.; White, S. H. Structure, Location, and Lipid Perturbations of Melittin at the Membrane Interface. Biophysical Journal 80 (2), 801-811.

14. Domingues, M. M.; Bianconi, M. L.; Barbosa, L. R. S.; Santiago, P. S.; Tabak, M.; Castanho, M. A. R. B.; Itri, R.; Santos, N. C. rBPI21 interacts with negative membranes endothermically promoting the formation of rigid multilamellar structures. Biochimica et Biophysica Acta (BBA) Biomembranes 2013, 1828 (11), 2419-2427.

15. Su, C.-J.; Wu, S.-S.; Jeng, U. S.; Lee, M.-T.; Su, A.-C.; Liao, K.-F.; Lin, W.-Y.; Huang, Y.-S.; Chen, C.-Y. Peptide-induced bilayer thinning structure of unilamellar vesicles and the related binding behavior as revealed by X-ray scattering. Biochimica et Biophysica Acta (BBA) - Biomembranes 2013, 1828 (2), 528-534. 
16. Castelletto, V.; Cheng, G.; Stain, C.; Connon, C. J.; Hamley, I. W. Self-assembly of a peptide amphiphile containing L-carnosine and its mixtures with a multilamellar vesicle forming lipid. Langmuir 2012, 28 (31), 11599-608.

17. Delin, S.; Jan, F.; Clifford, E. W. Current Understanding of the Mechanisms by which Membrane-Active Peptides Permeate and Disrupt Model Lipid Membranes. Current Topics in Medicinal Chemistry 2016, 16 (2), 170-186.

18. Moshe, L.; Saper, G.; Szekely, O.; Linde, Y.; Gilon, C.; Harries, D.; Raviv, U. Modulating the structure and interactions of lipid-peptide complexes by varying membrane composition and solution conditions. Soft Matter 2013, 9 (29), 7117-7126.

19. Fu, M.; Li, Q.; Sun, B.; Yang, Y.; Dai, L.; Nylander, T.; Li, J. Disassembly of Dipeptide Single Crystals Can Transform the Lipid Membrane into a Network. ACS Nano 2017, 11 (7), 73497354.

20. Cenker, C.; Bucak, S.; Olsson, U. Nanotubes and bilayers in a model peptide system (vol 7, pg 4868, 2011). Soft Matter 2011, 7 (24), 11548-11548.

21. Reches, M.; Porat, Y.; Gazit, E. Amyloid fibril formation by pentapeptide and tetrapeptide fragments of human calcitonin. J Biol Chem 2002, 277 (38), 35475-80.

22. Reches, M.; Gazit, E. Casting metal nanowires within discrete self-assembled peptide nanotubes. Science 2003, 300 (5619), 625-7.

23. Reches, M.; Gazit, E. Controlled patterning of aligned self-assembled peptide nanotubes. Nat Nanotechnol 2006, 1 (3), 195-200.

24. Yan, X.; Zhu, P.; Li, J. Self-assembly and application of diphenylalanine-based nanostructures. Chem Soc Rev 2010, 39 (6), 1877-90.

25. Yan, X.; He, Q.; Wang, K.; Duan, L.; Cui, Y.; Li, J. Transition of Cationic Dipeptide Nanotubes into Vesicles and Oligonucleotide Delivery. Angewandte Chemie International Edition 2007, 46 (14), 2431-2434.

26. Demirel, G.; Malvadkar, N.; Demirel, M. C. Control of Protein Adsorption onto Core-Shell Tubular and Vesicular Structures of Diphenylalanine/Parylene. Langmuir 2010, 26 (3), 1460-1463.

27. Silva, P. I.; Daffre, S.; Bulet, P. Isolation and characterization of gomesin, an 18-residue cysteine-rich defense peptide from the spider Acanthoscurria gomesiana hemocytes with sequence similarities to horseshoe crab antimicrobial peptides of the tachyplesin family. Journal of Biological Chemistry 2000, 275 (43), 33464-33470.

28. Mitta, G.; Hubert, F.; Noel, T.; Roch, P. Myticin, a novel cysteine-rich antimicrobial peptide isolated from haemocytes and plasma of the mussel Mytilus galloprovincialis. European Journal of Biochemistry 1999, 265 (1), 71-78.

29. Pabst, G.; Danner, S.; Podgornik, R.; Katsaras, J. Entropy-Driven Softening of Fluid Lipid Bilayers by Alamethicin. Langmuir 2007, 23 (23), 11705-11711.

30. Liberato, M. S.; Kogikoski, S.; da Silva, E. R.; Silva, R. H.; Oliveira, V. X.; Scott, L. P.; Ando, R. A.; Alves, W. A.; Coutinho-Neto, M. D. Self-Assembly of Arg-Phe Nanostructures via the Solid-Vapor Phase Method. J Phys Chem B 2013, 117, 733-740.

31. da Silva, E. R.; de Oliveira, E. A.; Fevrier, A.; Nallet, F.; Navailles, L. Supramolecular polymorphism of DNA in non-cationic Lalpha lipid phases. Eur Phys J E Soft Matter 2011, 34 (8), 83.

32. Oliveira, E. A. d.; Silva, E. R. T. d.; Février, A.; É, G.; Nallet, F.; Navailles, L. Confinementinduced phase transition in a DNA-lipid hydrated complex. EPL (Europhysics Letters) 2010, 91 (2), 28001.

33. Bridelli, M.; Capelletti, R.; Mora, C. Structural features and functional properties of water in model DMPC membranes: thermally stimulated depolarization currents (TSDCs) and Fourier transform infrared (FTIR) studies. Journal of Physics D-Applied Physics 2013, 46 (48).

34. de Oliveira, C. L. P.; Pedersen, J. Program package for data treatment,

analysis and modeling, $1 ; \ldots 2009$. 
35. Oliveira, C.; Gerbelli, B.; Silva, E.; Nallet, F.; Navailles, L.; Oliveira, E.; Pedersen, J. Gaussian deconvolution: a useful method for a form-free modeling of scattering data from monoand multilayered planar systems. Journal of Applied Crystallograpby 2012, 45, 1278-1286.

36. Gerbelli, B. B.; Rubim, R. L.; Silva, E. R.; Nallet, F.; Navailles, L.; Oliveira, C. L. P.; de Oliveira, E. A. Steric-Induced Effects on Stabilizing a Lamellar Structure. Langmuir 2013, 29 (45), 13717-13722.

37. Zemb , T.; Lindner, P. Neutrons, X-rays and Light : Scattering Methods Applied to Soft Condensed Matter, Elsevier2002. p 541.

38. Popova, A.; Hincha, D. Intermolecular interactions in dry and rehydrated pure and mixed bilayers of phosphatidylcholine and digalactosyldiacylglycerol: a Fourier transform infrared spectroscopy study. Biophysical Journal 2003, 85 (3), 1682-1690.

39. Nzai, J. M.; Proctor, A. Soy lecithin phospholipid determination by fourier transform infrared spectroscopy and the acid digest/arseno-molybdate method: A comparative study. Journal of the American Oil Chemists' Society 1999, 76 (1), 61-66.

40. Lewis, R. N. A. H.; McElhaney, R. N. Fourier Transform Infrared Spectroscopy in the Study of Lipid Phase Transitions in Model and Biological Membranes. In Methods in Membrane Lipids, Dopico, A. M., Ed.; Humana Press: Totowa, NJ, 2007, pp 207-226.

41. Frias, M.; Diaz, S.; Ale, N.; Ben Altabef, A.; Disalvo, E. FTIR analysis of the interaction of arbutin with dimyristoyl phosphatidylcholine in anhydrous and hydrated states. Biochimica Et Biophysica Acta-Biomembranes 2006, 1758 (11), 1823-1829.

42. Dashnau, J.; Nucci, N.; Sharp, K.; Vanderkooi, J. Hydrogen bonding and the cryoprotective properties of glycerol/water mixtures. Journal of Physical Chemistry B 2006, 110 (27), 13670-13677.

43. VandeVondele, J.; Troster, P.; Tavan, P.; Mathias, G. Vibrational Spectra of Phosphate Ions in Aqueous Solution Probed by First-Principles Molecular Dynamics. Journal of Physical Chemistry a 2012, 116 (10), 2466-2474.

44. Pabst, G.; Rappolt, M.; Amenitsch, H.; Laggner, P. Structural information from multilamellar liposomes at full hydration: Full q-range fitting with high quality x-ray data. Physical Review E 2000, 62 (3), 4000-4009.

45. Gorbitz, C. H. The structure of nanotubes formed by diphenylalanine, the core recognition motif of Alzheimer's [small beta]-amyloid polypeptide. Chemical Communications 2006, (22), 2332 2334.

46. Ryu, J.; Park, C. B. High Stability of Self-Assembled Peptide Nanowires Against Thermal, Chemical, and Proteolytic Attacks. Biotechnology and Bioengineering 2010, 105 (2), 221-230.

47. Adler-Abramovich, L.; Reches, M.; Sedman, V. L.; Allen, S.; Tendler, S. J. B.; Gazit, E. Thermal and chemical stability of diphenylalanine peptide nanotubes: Implications for nanotechnological applications. Langmuir 2006, 22 (3), 1313-1320.

48. Gupta, M.; Bagaria, A.; Mishra, A.; Mathur, P.; Basu, A.; Ramakumar, S.; Chauhan, V. S. Self-Assembly of a Dipeptide- Containing Conformationally Restricted Dehydrophenylalanine Residue to Form Ordered Nanotubes. Advanced Materials 2007, 19 (6), 858-861.

49. Barth, A. Infrared spectroscopy of proteins. Biochimica et Biophysica Acta (BBA) - Bioenergetics 2007, 1767 (9), 1073-1101.

50. Barth, A. The infrared absorption of amino acid side chains. Prog Biophys Mol Biol 2000, 74 (3-5), 141-73.

51. Terzi, E.; Hölzemann, G.; Seelig, J. Self-association of $\beta$-Amyloid Peptide (1-40) in Solution and Binding to Lipid Membranes. Journal of Molecular Biology 1995, 252 (5), 633-642.

52. Devanathan, S.; Salamon, Z.; Lindblom, G.; Gröbner, G.; Tollin, G. Effects of sphingomyelin, cholesterol and zinc ions on the binding, insertion and aggregation of the amyloid A 1 -40 peptide in solid-supported lipid bilayers. Febs J 2006, 273 (7), 1389-1402.

53. Hoshino, T.; Mahmood, M. I.; Mori, K.; Matsuzaki, K. Binding and Aggregation Mechanism of Amyloid $\beta$-Peptides onto the GM1 Ganglioside-Containing Lipid Membrane. The Journal of Physical Chemistry B 2013, 117 (27), 8085-8094. 
54. $\quad$ Lindberg, D. J.; Wesén, E.; Björkeroth, J.; Rocha, S.; Esbjörner, E. K. Lipid membranes catalyse the fibril formation of the amyloid- $\beta(1-42)$ peptide through lipid-fibril interactions that reinforce secondary pathways. Biochimica et Biophysica Acta (BBA) - Biomembranes 2017, 1859 (10), 1921-1929.

\section{TOC Entry}

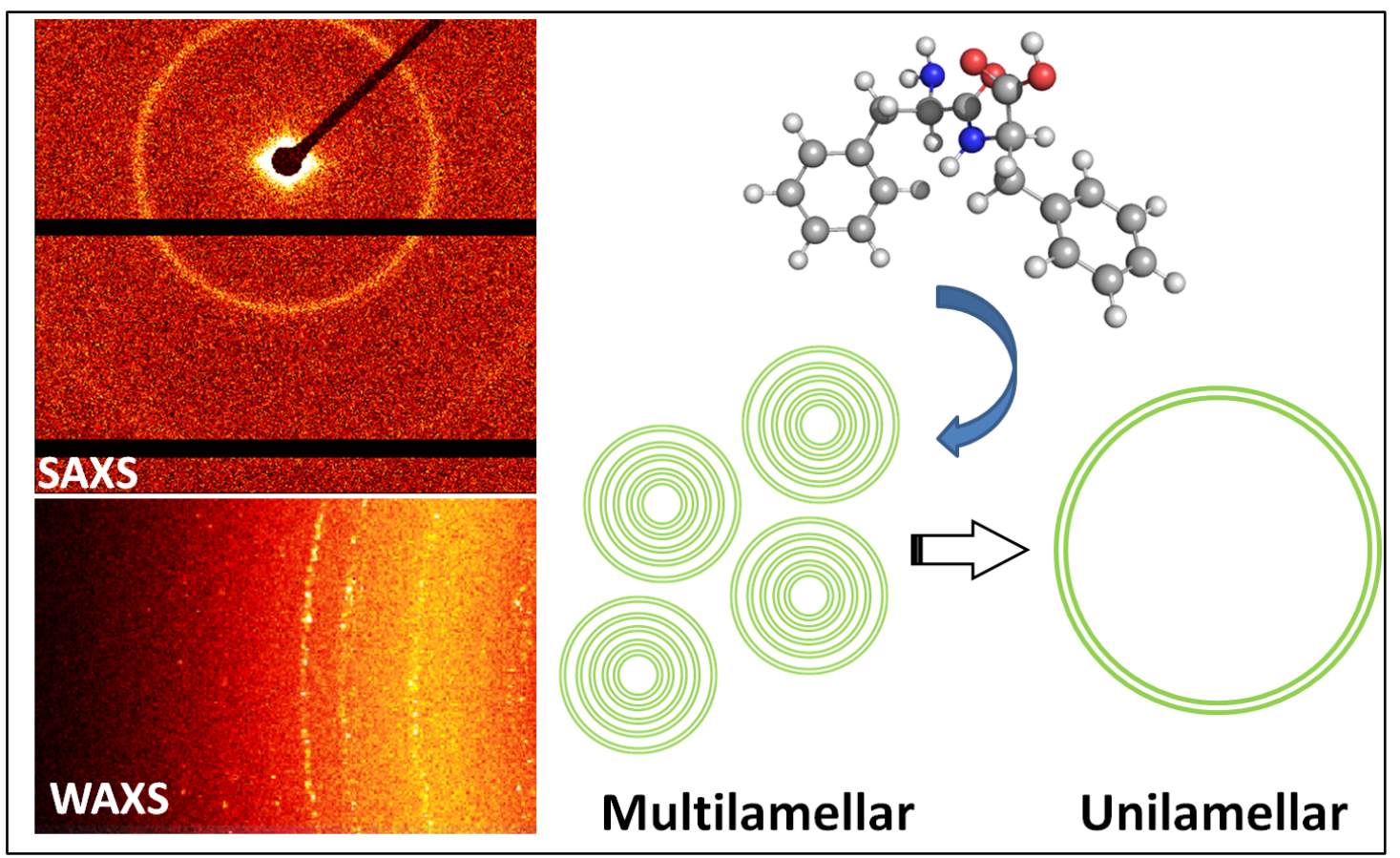




\section{Síntese do peptídeo CFF}

O peptídeo foi sintetizado pelo método de fase sólida, via estratégia Fmoc. O aminoácido de partida encontrava-se previamente acoplado à resina Wang como suporte sólido. O grupo protetor da amina foi removido com 4-metilpiperidina em dimetilformamida (DMF). Em seguida, os acoplamentos foram realizados utilizando um excesso de N,N'-diisopropilcarbodimida/hidrato de 1-hidróxibenzotriazol (DIC/HOBt) em 1-metil-2-pirrolidinona (NMP). O monitoramento da reação foi realizado mediante o teste de Kaiser. Os peptídeos foram clivados da resina numa reação com ácido trifluoroacético, triisopropilsilano e água, juntamente com o agente redutor ditiotreitol (DTT). Posteriormente, o peptídeo foi precipitado utilizando éter dietílico gelado. Por fim, a substituição do ácido foi promovida utilizando uma solução de ácido clorídrico 1\%, havendo posterior liofilização. A caracterização foi realizada por cromatografia líquida/espectrometria de massa com ionização por electrospray (HPLC-MS/ESI) e ressonância magnética nuclear (RMN), mostrando que não havia necessidade de purificação do material. 


\section{REFERÊNCIAS BIBLIOGRÁFICAS}

ADLER-ABRAMOVICH, L. et al. Thermal and chemical stability of diphenylalanine peptide nanotubes: Implications for nanotechnological applications. Langmuir, v. 22, n. 3, p. 1313-1320, JAN 3120062006. ISSN 0743-7463.

AKBARZADEH, A. et al. Liposome: classification, preparation, and applications. Nanoscale Research Letters, v. 8, FEB 222013 2013. ISSN 1556-276X.

ANGELATOS, A. S.; KATAGIRI, K.; CARUSO, F. Bioinspired colloidal systems via layer-by-layer assembly. Soft Matter, v. 2, n. 1, p. 18-23, Jan 2006. ISSN 1744-683X. Disponível em: < <Go to ISI>://WOS:000234586400003 >.

BAGGERJORGENSEN, H.; OLSSON, U. Experimental study of undulation forces in a nonionic lamellar phase. Langmuir, v. 12, n. 17, p. 4057-4059, AUG 211996 1996. ISSN 0743-7463.

BALBINO, T. et al. Continuous flow production of cationic liposomes at high lipid concentration in microfluidic devices for gene delivery applications. Chemical Engineering Journal, v. 226, p. 423-433, JUN 152013 2013. ISSN 1385-8947.

BARTH, A. The infrared absorption of amino acid side chains. Prog Biophys Mol Biol, v. 74, n. 3-5, p. 141-73, 2000. ISSN 0079-6107 (Print)

0079-6107 (Linking). Disponível em: < http://www.ncbi.nlm.nih.gov/entrez/query.fcgi? cmd=Retrieve\&db=PubMed\&dopt=Citation\& list_uids $=11226511>$.

. Infrared spectroscopy of proteins. Biochimica et Biophysica Acta (BBA) - Bioenergetics, v. 1767, n. 9, p. 1073-1101, 2007/09/01/ 2007. ISSN 0005-2728. Disponível em: < http://www.sciencedirect.com/science/article/pii/S0005272807001375 >.

BERNARD DENNIS CULLITY , S. R. S. Elements of X-ray Diffraction. . Universidade de Michigan: . 2001. 664.

BIORRUPTOR. Bio ruptor Sonication System. Version 2.1. MANUAL.

BOUGIS, K. Fluctuations et interactions ensituation de nano-confinementanisotrope. 2016. . (.). . UNIVERSITÉ DE BORDEAUX, UNIVERSITÉ DE BORDEAUX. 
BRIDELLI, M.; CAPELLETTI, R.; MORA, C. Structural features and functional properties of water in model DMPC membranes: thermally stimulated depolarization currents (TSDCs) and Fourier transform infrared (FTIR) studies. Journal of Physics D-Applied Physics, v. 46, n. 48, DEC 42013 2013. ISSN $0022-$ 3727.

CAILLE, A. X-RAY SCATTERING BY SMECTIC-A CRYSTALS. Comptes Rendus Hebdomadaires Des Seances De L Academie Des Sciences Serie B, v. 274, n. 14, p. 891-\&, 19721972.

CAPITO, R. M. et al. Self-assembly of large and small molecules into hierarchically ordered sacs and membranes. Science, v. 319, n. 5871, p. 1812-6, Mar 28 2008. ISSN 1095-9203 (Electronic)

0036-8075 (Linking). Disponível em: < http://www.ncbi.nlm.nih.gov/entrez/query.fcgi? $\mathrm{cmd}=$ Retrieve \&db=PubMed\&dopt=Citation \& $\underline{\text { list_uids }=18369143}>$.Disponível em: $<\underline{\text { http: } / / w w w . s c i e n c e m a g . o r g / c o n t e n t / 319 / 5871 / 1812 ~}>$.

CASTELLETTO, V. et al. Influence of elastase on alanine-rich peptide hydrogels. Biomaterials Science, v. 2, n. 6, p. 867-874, 2014 2014. ISSN 2047-4830.

CATALA, A. Lipid peroxidation modifies the picture of membranes from the "Fluid Mosaic Model" to the "Lipid Whisker Model". Biochimie, v. 94, n. 1, p. 101-109, Jan 2012. ISSN 0300-9084. Disponível em: $<<$ Go to $|S|>: / / W O S: 000300473200012>$.

CENKER, C.; BUCAK, S.; OLSSON, U. Nanotubes and bilayers in a model peptide system (vol 7, pg 4868, 2011). Soft Matter, v. 7, n. 24, p. 11548-11548, 2011 2011. ISSN 1744-683X.

CHITI, F.; DOBSON, C. M. Protein misfolding, functional amyloid, and human disease. Annual Review of Biochemistry, v. 75, p. 333-366, 2006. ISSN 0066-4154. Disponível em: < <Go to $|S|>: / / 000239807600014>$.

COLIN, A.; ROUX, D. Incorporating DNA in a lamellar phase: A Flory model. European Physical Journal E, v. 8, n. 5, p. 499-506, Aug 2002. ISSN 1292-8941. Disponível em: < <Go to $|S|>: / / W O S: 000179575000006>$.

COX, D. L. N. M. M. Princípios de Bioquímica de Lehninger. 6. . 2012. .

DA SILVA, E. et al. Supramolecular polymorphism of DNA in non-cationic L-alpha lipid phases. European Physical Journal E, v. 34, n. 8, AUG 2011 2011. ISSN 1292-8941.

DAN, N. L. Multilamellar structures of DNA complexes with cationic liposomes. Biophysical Journal, v. 73, n. 4, p. 1842-1846, Oct 1997. ISSN 0006-3495. Disponível em: < <Go to ISI>://WOS:A1997XY95500013 >.

DE OLIVEIRA , C. L. P.; PEDERSEN, J. Program package for data treatment, 
analysis and modeling. . .Program package for data treatment,

analysis and modeling p. 2009.

DE OLIVEIRA, E. A. et al. Confinement-induced phase transition in a DNA-lipid hydrated complex. Epl, v. 91, n. 2, p. 6, Jul 2010. ISSN 0295-5075. Disponível em: < <Go to ISI>://WOS:000282189500017 >.

DEHSORKHI, A. et al. Interaction between a cationic surfactant-like peptide and lipid vesicles and its relationship to antimicrobial activity. Langmuir, v. 29, n. 46, p. 14246-53, Nov 19 2013. ISSN 1520-5827 (Electronic)

0743-7463 (Linking). Disponível em: < http://www.ncbi.nlm.nih.gov/entrez/query.fcgi? cmd=Retrieve\&db=PubMed\&dopt=Citation\& list uids $=24156610>$.

DELIN, S.; JAN, F.; CLIFFORD, E. W. Current Understanding of the Mechanisms by which MembraneActive Peptides Permeate and Disrupt Model Lipid Membranes. Current Topics in Medicinal Chemistry, v. 16, n. 2, p. 170-186, 2016. ISSN 1568-0266/1873-4294. Disponível em: < http://www.eurekaselect.com/node/133899/article $>$.

DOBSON, C. B.; WOZNIAK, M. A.; ITZHAKI, R. F. Do infectious agents play a role in dementia? Trends in Microbiology, v. 11 , n. 7, p. 312-317, Jul 2003. ISSN 0966-842X. Disponível em: < <Go to $|S|>: / / 000184538200006>$.

DOMINGUES, M. M. et al. rBPI21 interacts with negative membranes endothermically promoting the formation of rigid multilamellar structures. Biochimica et Biophysica Acta (BBA) - Biomembranes, v. 1828, n. 11, p. 2419-2427, 2013. ISSN 0005-2736. Disponível em: < https://www.sciencedirect.com/science/article/pii/S0005273613001983 >.

EWERT, K. et al. A columnar phase of dendritic lipid-based cationic liposome-DNA complexes for gene delivery: Hexagonally ordered cylindrical micelles embedded in a DNA honeycomb lattice. Journal of the American Chemical Society, v. 128, n. 12, p. 3998-4006, MAR 292006 2006. ISSN 0002-7863.

FRIAS, M. et al. FTIR analysis of the interaction of arbutin with dimyristoyl phosphatidylcholine in anhydrous and hydrated states. Biochimica Et Biophysica Acta-Biomembranes, v. 1758, n. 11, p. 18231829, NOV 2006 2006. ISSN 0005-2736.

FU, M. et al. Disassembly of Dipeptide Single Crystals Can Transform the Lipid Membrane into a Network. ACS Nano, v. 11, n. 7, p. 7349-7354, 2017/07/25 2017. ISSN 1936-0851. Disponível em: < http://dx.doi.org/10.1021/acsnano.7b03468 >.

GELB, L. D.; GUBBINS, K. E. Phase separation in confined systems (vol 62, pg 1573, 1999). Reports on Progress in Physics, v. 63, n. 4, p. 727-727, Apr 2000. ISSN 0034-4885. Disponível em: <<Go to |SI $>$ ://WOS:000086770100005 >. 
GERBELLI, B. et al. Steric-Induced Effects on Stabilizing a Lamellar Structure. Langmuir, v. 29, n. 45, p. 13717-13722, NOV 122013 2013. ISSN 0743-7463.

GERBELLI, B. B. Propriedades estruturais e elásticas de fases lamelares: $\mathbf{O}$ efeito da composição da membrana 2012. (Dissertação de mestrado). Universidade de São Paulo, São Paulo.

GLATTER, O. Fourier Transforms and Deconvolution (Chapter 5). In Neutrons, X-rays and Light Elsevier Science B.V. , 2002.

GLATTER, O.; KRATKY, O. Small Angle X-ray Scattering. Academic Pr, 1982. 525.

GONI, F. The basic structure and dynamics of cell membranes: An update of the Singer-Nicolson model. Biochimica Et Biophysica Acta-Biomembranes, v. 1838, n. 6, p. 1467-1476, JUN 2014 2014. ISSN 00052736.

GORBITZ, C. The structure of nanotubes formed by diphenylalanine, the core recognition motif of Alzheimer's beta-amyloid polypeptide. Chemical Communications, n. 22, p. 2332-2334, 20062006. ISSN 1359-7345.

GOÑI, F. M. The basic structure and dynamics of cell membranes: An update of the Singer-Nicolson model. Biochimica et Biophysica Acta (BBA) - Biomembranes, v. 1838, n. 6, p. 1467-1476, 2014. ISSN 0005-2736. Disponível em:

http://www.sciencedirect.com/science/article/pii/S000527361400008X >.

GUPTA, M. et al. Self-assembly of a dipeptide-containing conformationally restricted dehydrophenylalanine residue to form ordered nanotubes. Advanced Materials, v. 19, n. 6, p. 858-+, MAR 192007 2007. ISSN 0935-9648.

HAMLEY, I. W. Peptide fibrillization. Angew Chem Int Ed Engl, v. 46, n. 43, p. 8128-47, 2007. ISSN 15213773 (Electronic)
$1433-7851$
(Linking).
Disponível
em:
$<$

http://www.ncbi.nlm.nih.gov/entrez/query.fcgi? $\mathrm{cmd}=$ Retrieve \&db=PubMed\&dopt=Citation\& list uids $=17935097>$.

. The Amyloid Beta Peptide: A Chemist's Perspective. Role in Alzheimer's and Fibrillization. Chemical Reviews, v. 112, n. 10, p. 5147-5192, Oct 2012. ISSN 0009-2665. Disponível em: <<Go to $|S|>: / /$ WOS:000309628100004 >.

HAMLEY, I. W.; CASTELLETTO, V. Biological soft materials. Angew Chem Int Ed Engl, v. 46, n. 24, p. 4442-55, 2007. ISSN 1433-7851 (Print) 
$1433-7851$

(Linking).

Disponível

em:

http://www.ncbi.nlm.nih.gov/entrez/query.fcgi? $\mathrm{cmd}=$ Retrieve \&db=PubMed\&dopt=Citation \& list uids $=17516592>$.

HELFRICH, W. STERIC INTERACTION OF FLUID MEMBRANES IN MULTILAYER SYSTEMS. Zeitschrift Fur Naturforschung Section a-a Journal of Physical Sciences, v. 33, n. 3, p. 305-315, 1978 1978. ISSN 09320784.

HEREDIA, A. et al. Temperature-driven phase transformation in self-assembled diphenylalanine peptide nanotubes. Journal of Physics D-Applied Physics, v. 43, n. 46, NOV 242010 2010. ISSN 0022 3727.

HRISTOVA, K.; DEMPSEY, C. E.; WHITE, S. H. Structure, Location, and Lipid Perturbations of Melittin at the Membrane Interface. Biophysical Journal, v. 80, n. 2, p. 801-811, ISSN 0006-3495. Disponível em: < http://dx.doi.org/10.1016/S0006-3495(01)76059-6 >. Acesso em: 2017/10/30.

ISRAELACHVILI, J. REFINEMENT OF FLUID-MOSAIC MODEL OF MEMBRANE STRUCTURE. Biochimica Et Biophysica Acta, v. 469, n. 2, p. 221-225, 1977 1977. ISSN 0006-3002.

JENDRASIAK, G.; SMITH, R.; MCINTOSH, T. The effect of phloretin on the hydration of egg phosphatidylcholine multilayers. Biochimica Et Biophysica Acta-Biomembranes, v. 1329, n. 1, p. 159168, OCT 21997 1997. ISSN 0005-2736.

JONES, R. A. L. Soft Condensed Matter. 6. . . 2002. .

KAHN, M. et al. Ordered equilibrium structures in soft matter systems between two and three dimensions. Soft Matter, v. 5, n. 15, p. 2852-2857, 2009. ISSN 1744-683X. Disponível em: <<Go to $|S|>: / /$ WOS:000268183900005 >.

KARMAKAR, S.; RAGHUNATHAN, V. Structure of phospholipid-cholesterol membranes: An x-ray diffraction study. Physical Review E, v. 71, n. 6, JUN 2005 2005. ISSN 1539-3755.

KASOJI, S. et al. Cavitation Enhancing Nanodroplets Mediate Efficient DNA Fragmentation in a Bench Top Ultrasonic Water Bath. Plos One, v. 10, n. 7, JUL 172015 2015. ISSN 1932-6203.

KATSARAS, J. et al. Clarification of the ripple phase of lecithin bilayers using fully hydrated, aligned samples. Physical Review E, v. 61, n. 5, p. 5668-5677, MAY 2000 2000a. ISSN 1063-651X.

Revisiting the ripple phase using fully hydrated, aligned DPPC multibilayers. Biophysical Journal, v. 78, n. 1, p. 20A-20A, JAN 2000 2000b. ISSN 0006-3495. 
KIM, D. et al. Synthesis of Uniform Ferrimagnetic Magnetite Nanocubes. Journal of the American Chemical Society, v. 131, n. 2, p. 454-+, Jan 2009. ISSN 0002-7863. Disponível em: < <Go to $\mid$ SI $>$ ://WOS:000262521800029 >.

KOLTOVER, I. et al. An inverted hexagonal phase of cationic liposome-DNA complexes related to DNA release and delivery. Science, v. 281, n. 5373, p. 78-81, JUL 31998 1998. ISSN 0036-8075.

KOPPEL, D. ANALYSIS OF MACROMOLECULAR POLYDISPERSITY IN INTENSITY CORRELATION SPECTROSCOPY - METHOD OF CUMULANTS. Journal of Chemical Physics, v. 57, n. 11, p. 4814-\&, 1972 1972. ISSN 0021-9606.

KOYNOVA, R.; TENCHOV, B. Cationic phospholipids: structure-transfection activity relationships. Soft Matter, v. 5, n. 17, p. 3187-3200, 2009. ISSN 1744-683X. Disponível em: < <Go to $\mid$ ISI>://WOS:000269062900005 >.

LANGER, R.; TIRRELL, D. A. Designing materials for biology and medicine. Nature, v. 428, n. 6982, p. 487-492, Apr 2004. ISSN 0028-0836. Disponível em: <<Go to ISI>://WOS:000220540100031 >.

LEWIS, R. N. A. H.; MCELHANEY, R. N. Fourier Transform Infrared Spectroscopy in the Study of Lipid Phase Transitions in Model and Biological Membranes. In: DOPICO, A. M. (Ed.). Methods in Membrane Lipids. Totowa, NJ: Humana Press, 2007. p.207-226. ISBN 978-1-59745-519-0.

LI, Y.; BARRON, A. R. Dynamic Light Scattering. \& http://creativecommons.org/licenses/by/4.0/: OpenStax-CNX module: m50236. . Versão 1.2 p. 2014.

LIVOLANT, F.; LEFORESTIER, A. Condensed phases of DNA: Structures and phase transitions. Progress in Polymer Science, v. 21, n. 6, p. 1115-1164, 1996 1996. ISSN 0079-6700.

LUO, D.; SALTZMAN, W. M. Synthetic DNA delivery systems. Nature Biotechnology, v. 18, n. 1, p. 3337, Jan 2000. ISSN 1087-0156. Disponível em:<<Go to ISI>://WOS:000084699900021 >.

LUZZATI, V.; TARDIEU, A. LIPID PHASES - STRUCTURE AND STRUCTURAL TRANSITIONS. Annual Review of Physical Chemistry, v. 25, p. 79-94, 1974 1974. ISSN 0066-426X.

MALANOVIC, N. et al. Phospholipid-driven differences determine the action of the synthetic antimicrobial peptide OP-145 on Gram-positive bacterial and mammalian membrane model systems. Biochimica Et Biophysica Acta-Biomembranes, v. 1848, n. 10, p. 2437-2447, Oct 2015. ISSN 00052736. Disponível em:<<Go to ISI >://WOS:000362153400054 >.

MAXIM RYADNOV FERENC HUDECZ , H. T. E. N. A. M. E. F. T. H. S. R. Amino Acids, Peptides and Proteins. 6. . 20017. . 
MITTA, G. et al. Myticin, a novel cysteine-rich antimicrobial peptide isolated from haemocytes and plasma of the mussel Mytilus galloprovincialis. European Journal of Biochemistry, v. 265, n. 1, p. 7178, Oct 1999. ISSN 0014-2956. Disponível em: <<Go to ISI>://WOS:000082893000008 >.

MONIRUZZAMAN, M. et al. Entry of a Six-Residue Antimicrobial Peptide Derived from Lactoferricin B into Single Vesicles and Escherichia coli Cells without Damaging their Membranes. Biochemistry, v. 56, n. 33, p. 4419-4431, 2017/08/22 2017. ISSN 0006-2960. Disponível em: < http://dx.doi.org/10.1021/acs.biochem.6b01274 >.

MOSHE, L. et al. Modulating the structure and interactions of lipid-peptide complexes by varying membrane composition and solution conditions. Soft Matter, v. 9, n. 29, p. 7117-7126, 2013. ISSN 1744-683X. Disponível em: < http://dx.doi.org/10.1039/C3SM00105A >.

MURRAY, S. M. et al. The Fluid-Mosaic Model, Homeoviscous Adaptation, and lonic Liquids: Dramatic Lowering of the Melting Point by Side-Chain Unsaturation. Angewandte Chemie-International Edition, v. 49, n. 15, p. 2755-2758, 2010 2010. ISSN 1433-7851. Disponível em: < <Go to $|S|>: / /$ WOS:000276780500021 >.

NAGLE, J.; TRISTRAM-NAGLE, S. Lipid bilayer structure. Current Opinion in Structural Biology, v. 10, n. 4, p. 474-480, AUG 2000 2000a. ISSN 0959-440X.

. Structure of lipid bilayers. Biochimica Et Biophysica Acta-Reviews on Biomembranes, v. 1469, n. 3, p. 159-195, NOV 102000 2000b. ISSN 0304-4157.

NALLET, F.; LAVERSANNE, R.; ROUX, D. MODELING X-RAY OR NEUTRON-SCATTERING SPECTRA OF LYOTROPIC LAMELLAR PHASES - INTERPLAY BETWEEN FORM AND STRUCTURE FACTORS. Journal De Physique li, v. 3, n. 4, p. 487-502, APR 1993 1993. ISSN 1155-4312.

NALLET, F.; ROUX, D.; PROST, J. HYDRODYNAMICS OF LYOTROPIC SMECTICS - A DYNAMIC LIGHTSCATTERING STUDY OF DILUTE LAMELLAR PHASES. Journal De Physique, v. 50, n. 20, p. 3147-3165, OCT 151989 1989. ISSN 0302-0738.

NALLET, F. et al. ELASTICITY AND HYDRODYNAMIC PROPERTIES OF DOPED SOLVENT DILUTE LAMELLAR PHASES. Journal De Physique li, v. 4, n. 9, p. 1477-1499, SEP 1994 1994. ISSN 1155-4312.

NG, H.; KOPKA, M.; DICKERSON, R. The structure of a stable intermediate in the A <-> B DNA helix transition. Proceedings of the National Academy of Sciences of the United States of America, v. 97, n. 5, p. 2035-2039, FEB 292000 2000. ISSN 0027-8424.

NICOLAU, C.; DREESKAMP, H.; SCHULTEF.D. NUCLEAR-C-13 MAGNETIC-RESONANCE RELAXATION MEASUREMENTS OF ALPHA-LECITHIN-PEPTIDE INTERACTION IN MODEL MEMBRANES. Febs Letters, $v$. 43, n. 2, p. 148-150, 1974 1974. ISSN 0014-5793. 
NICOLSON, G. L. The Fluid-Mosaic Model of Membrane Structure: Still relevant to understanding the structure, function and dynamics of biological membranes after more than 40 years. Biochimica Et Biophysica Acta-Biomembranes, v. 1838, n. 6, p. 1451-1466, Jun 2014. ISSN 0005-2736. Disponível em: $<<$ Go to $|S|>$ ://WOS:000335619200002 >.

NYGARD, K. et al. Confinement-induced orientational alignment of quasi-2D fluids. Epl, v. 86, n. 6, p. 5, Jun 2009. ISSN 0295-5075. Disponível em: <<Go to ISI>://WOS:000269357700018 >.

NZAI, J. M.; PROCTOR, A. Soy lecithin phospholipid determination by fourier transform infrared spectroscopy and the acid digest/arseno-molybdate method: A comparative study. Journal of the American Oil Chemists' Society, v. 76, n. 1, p. 61-66, 1999. ISSN 1558-9331. Disponível em: < http://dx.doi.org/10.1007/s11746-999-0048-9 >.

OCHMAN, H.; GERBER, A.; HARTL, D. GENETIC APPLICATIONS OF AN INVERSE POLYMERASE CHAINREACTION. Genetics, v. 120, n. 3, p. 621-623, NOV 1988 1988. ISSN 0016-6731.

ODRIOZOLA, G.; JIMENEZ-ANGELES, F.; LOZADA-CASSOU, M. Effect of confinement on the interaction between two like-charged rods. Physical Review Letters, v. 97, n. 1, p. 4, Jul 2006. ISSN 0031-9007. Disponível em: <<Go to ISI >://WOS:000238849000056 >.

OLIVEIRA, C. et al. Gaussian deconvolution: a useful method for a form-free modeling of scattering data from mono- and multilayered planar systems. Journal of Applied Crystallography, v. 45, p. 12781286, DEC 2012 2012. ISSN 0021-8898.

OLIVEIRA, C. L. P. D. 2005. 283 (Tese de doutoramento). . Universidade de Campinas, São Paulo.

P. G. DE GENNES , J. P. The Physics of Liquid Crystals. . Clarendon Press, 1995: 1995. 616

PABST, G. GLOBAL PROPERTIES OF BIOMIMETIC MEMBRANES: PERSPECTIVES ON MOLECULAR FEATURES. . . Biophysical Reviews and Letters: . 1: 57-84 p. 2005.

PABST, G. et al. Entropy-driven softening of fluid lipid Bilayers by alamethicin. Langmuir, v. 23, n. 23, p. 11705-11711, NOV 62007 2007. ISSN 0743-7463.

. Structural information from multilamellar liposomes at full hydration: Full q-range fitting with high quality x-ray data. Physical Review E, v. 62, n. 3, p. 4000-4009, SEP 2000 2000. ISSN 1063-651X.

PAN, J. et al. Alamethicin in lipid bilayers: Combined use of X-ray scattering and MD simulations. Biochimica et Biophysica Acta (BBA) - Biomembranes, v. 1788, n. 6, p. 1387-1397, 2009. ISSN 00052736. Disponível em: < http://www.sciencedirect.com/science/article/pii/S0005273609000716 >.

PECORA, R. Applications of Photon Correlation SpectroscopyDynamic Light Scattering: . Plenum Press, New York: Springer US, 1985. 424. 
PETRACHE, $\mathrm{H}$. et al. Interbilayer interactions from high-resolution $\mathrm{x}$-ray scattering. Physical Review E, v. 57, n. 6, p. 7014-7024, JUN 1998 1998. ISSN 1063-651X.

PODGORNIK, R.; STREY, H.; PARSEGIAN, V. Colloidal DNA. Current Opinion in Colloid \& Interface Science, v. 3, n. 5, p. 534-539, OCT 1998 1998. ISSN 1359-0294.

POPOVA, A.; HINCHA, D. Intermolecular interactions in dry and rehydrated pure and mixed bilayers of phosphatidylcholine and digalactosyldiacylglycerol: a Fourier transform infrared spectroscopy study. Biophysical Journal, v. 85, n. 3, p. 1682-1690, SEP 2003 2003. ISSN 0006-3495.

POTT, T. et al. DNA intercalation in neutral multilamellar membranes: Experiments and theory. Interface Science, v. 11, n. 2, p. 249-257, Apr 2003. ISSN 0927-7056. Disponível em: < <Go to $\mid$ ISI $>: / /$ WOS:000180687100010 >.

. Melittin modifies bending elasticity in an unexpected way. Chemistry and Physics of Lipids, v. 185, p. 99-108, Jan 2015. ISSN 0009-3084. Disponível em: <<Go to ISI>://WOS:000349935900008 >.

POTT, T.; ROUX, D. DNA intercalation in neutral multilamellar membranes. Febs Letters, v. 511, n. 1-3, p. 150-154, Jan 2002. ISSN 0014-5793. Disponível em: < <Go to ISI>://WOS:000173628000029 >.

RADLER, J. O. et al. Structure of DNA-cationic liposome complexes: DNA intercalation in multilamellar membranes in distinct interhelical packing regimes. Science, v. 275, n. 5301, p. 810-814, Feb 1997. ISSN 0036-8075. Disponível em: <<Go to ISI>://WOS:A1997WG77700054 >.

RAJAGOPAL, K.; SCHNEIDER, J. Self-assembling peptides and proteins for nanotechnological applications. Current Opinion in Structural Biology, v. 14, n. 4, p. 480-486, AUG 2004 2004. ISSN 0959440X.

RECHES, M.; GAZIT, E. Casting metal nanowires within discrete self-assembled peptide nanotubes. Science, v. 300, n. 5619, p. 625-7, Apr 25 2003. ISSN 1095-9203 (Electronic)

0036-8075 (Linking). Disponível em: < http://www.ncbi.nlm.nih.gov/entrez/query.fcgi? cmd=Retrieve\&db=PubMed\&dopt=Citation\& list_uids $=12714741>$.

. Casting metal nanowires within discrete self-assembled peptide nanotubes. Science, v. 300, n. 5619, p. 625-627, APR 252003 2003. ISSN 0036-8075.

. Controlled patterning of aligned self-assembled peptide nanotubes. Nat Nanotechnol, v. 1, n. 3, p. 195-200, Dec 2006. ISSN 1748-3395 (Electronic)

1748-3387 (Linking). Disponível em: < http://www.ncbi.nlm.nih.gov/entrez/query.fcgi? cmd=Retrieve\&db=PubMed\&dopt=Citation\& list uids $=18654186>$. 
RUBIM, R. et al. Water activity in lamellar stacks of lipid bilayers: "Hydration forces" revisited. European Physical Journal E, v. 39, n. 1, JAN 252016 2016. ISSN 1292-8941.

RYU, J.; PARK, C. B. High Stability of Self-Assembled Peptide Nanowires Against Thermal, Chemical, and Proteolytic Attacks. Biotechnology and Bioengineering, v. 105, n. 2, p. 221-230, Feb 2010. ISSN 00063592. Disponível em: <<Go to |S|>://WOS:000273715500001 >.

SACKMANN, E. Thermo-elasticity and adhesion as regulators of cell membrane architecture and function. Journal of Physics-Condensed Matter, v. 18, n. 45, p. R785-R825, Nov 2006. ISSN 0953-8984. Disponível em: <<Go to ISI : //WOS:000242504100003 >.

SALNIKOV, E. et al. Alamethicin Supramolecular Organization in Lipid Membranes from F-19 SolidState NMR. Biophysical Journal, v. 111, n. 11, p. 2450-2459, DEC 62016 2016. ISSN 0006-3495.

SANI, M.; SEPAROVIC, F. Localisation of the Antimicrobial Peptide Maculatin 1.1 in Lipid Bilayers using Solid-State NMR. Biophysical Journal, v. 110, n. 3, p. 78A-78A, FEB 162016 2016. ISSN 0006-3495.

SCHMIDTCHEN, A. et al. Membrane selectivity by W-tagging of antimicrobial peptides. Biochimica et Biophysica Acta (BBA) - Biomembranes, v. 1808, n. 4, p. 1081-1091, 2011. ISSN 0005-2736. Disponível em: < https://www.sciencedirect.com/science/article/pii/S0005273610004554 >.

SHARMA, A.; SHARMA, U. Liposomes in drug delivery: progress and limitations. International Journal of Pharmaceutics, v. 154, n. 2, p. 123-140, AUG 261997 1997. ISSN 0378-5173.

SIDDHANTA, A.; SHIELDS, D. Secretory vesicle budding from the trans-Golgi network is mediated by phosphatidic acid levels. Journal of Biological Chemistry, v. 273, n. 29, p. 17995-17998, Jul 1998. ISSN 0021-9258. Disponível em: <<Go to |SI|>://WOS:000074828500005 >.

SILVA, E. R. T. D. Estrutura e din^amica de DNA confinado entre membranas liṕodicas ñaocati^onicas 2007. 233 (Tese de doutoramento). FEP, Universidade de São Paulo, São Paulo.

SILVA, P. I.; DAFFRE, S.; BULET, P. Isolation and characterization of gomesin, an 18-residue cysteinerich defense peptide from the spider Acanthoscurria gomesiana hemocytes with sequence similarities to horseshoe crab antimicrobial peptides of the tachyplesin family. Journal of Biological Chemistry, v. 275, n. 43, p. 33464-33470, Oct 27 2000. ISSN 0021-9258. Disponível em: < <Go to $|S|>: / /$ WOS:000090104600041 >.

SINGER, S.; NICOLSON, G. The Fluid Mosaic Model of the Structure of Cell Membranes. Science, v. 175, n. 4023, p. 720-+, 1972 1972. ISSN 0036-8075. 
SINGER, S. J.; NICOLSON, G. L. FLUID MOSAIC MODEL OF STRUCTURE OF CELL-MEMBRANES. Science, v. 175, n. 4023, p. 720-\&, 1972 1972. ISSN 0036-8075. Disponível em: < <Go to |SI>://WOS:A1972L621300012 >.

SMITH, G. et al. X-RAY STUDY OF FREELY SUSPENDED FILMS OF A MULTILAMELLAR LIPID SYSTEM. Molecular Crystals and Liquid Crystals, v. 144, p. 235-255, 1987 1987. ISSN 0140-6566.

SMITH, J.; ZHANG, Y. L.; NIVEN, R. Toward development of a non-viral gene therapeutic. Advanced Drug Delivery Reviews, v. 26, n. 2-3, p. 135-150, Jul 1997. ISSN 0169-409X. Disponível em: < <Go to ISI>://WOS:A1997XM17900006 >.

SOROCHKINA, A. et al. Peptide-induced membrane leakage by lysine derivatives of gramicidin $A$ in liposomes, planar bilayers, and erythrocytes. Biochimica Et Biophysica Acta-Biomembranes, v. 1828, n. 11, p. 2428-2435, NOV 2013 2013. ISSN 0005-2736.

STANDLEY, S. M. et al. Induction of cancer cell death by self-assembling nanostructures incorporating a cytotoxic peptide. Cancer Res, v. 70, n. 8, p. 3020-6, Apr 15 2010. ISSN 1538-7445 (Electronic)

0008-5472 (Linking). Disponível em: < http://www.ncbi.nlm.nih.gov/entrez/query.fcgi? $\mathrm{cmd}=$ Retrieve \&db=PubMed\&dopt=Citation \& list_uids=20354185 >.Disponível em: < http://cancerres.aacrjournals.org/content/70/8/3020.full.pdf $>$.

STUART, B. H. INFRARED SPECTROSCOPY - FUNDAMENTALS AND APPLICATIONS. ESTADOS UNIDOS DA AMERICA: Wiley, 2004.

SU, C. et al. Peptide-induced bilayer thinning structure of unilamellar vesicles and the related binding behavior as revealed by X-ray scattering. Biochimica Et Biophysica Acta-Biomembranes, v. 1828, n. 2, p. 528-534, FEB 2013 2013. ISSN 0005-2736.

TANFORD, C. The hydrophobic effect: Formation of micelles and biological membrane. 6. New York.: . 1980. .

TELES, F.; FONSECA, L. Trends in DNA biosensors. Talanta, v. 77, n. 2, p. 606-623, DEC 1520082008. ISSN 0039-9140.

TERZI, E.; HÖLZEMANN, G.; SEELIG, J. Self-association of $\beta$-Amyloid Peptide (1-40) in Solution and Binding to Lipid Membranes. Journal of Molecular Biology, v. 252, n. 5, p. 633-642, 1995/10/06/ 1995. ISSN 0022-2836. Disponível em: < http://www.sciencedirect.com/science/article/pii/S0022283685705256 >.

TSAPIS, N. et al. Modification of the elastic constants of a peptide-decorated lamellar phase. Langmuir, v. 18, n. 11, p. 4384-4392, MAY 282002 2002. ISSN 0743-7463. 
VANDEVONDELE, J. et al. Vibrational Spectra of Phosphate lons in Aqueous Solution Probed by FirstPrinciples Molecular Dynamics. Journal of Physical Chemistry a, v. 116, n. 10, p. 2466-2474, MAR 15 2012 2012. ISSN 1089-5639.

\section{W.; FREENMAN, H. PhysicalChemistry}

for life sciene First Edition. São Paulo: Universidade de São Paulo, 2006.

WANG, K. F.; NAGARAJAN, R.; CAMESANO, T. A. Differentiating antimicrobial peptides interacting with lipid bilayer: Molecular signatures derived from quartz crystal microbalance with dissipation monitoring. Biophysical Chemistry, v. 196, p. 53-67, 2015. ISSN 0301-4622. Disponível em: < https://www.sciencedirect.com/science/article/pii/S0301462214001215 >.

WANG, W. C.; YANG, L.; HUANG, H. W. Evidence of cholesterol accumulated in high curvature regions: Implication to the curvature elastic energy for lipid mixtures. Biophysical Journal, v. 92, n. 8, p. 28192830, Apr 2007. ISSN 0006-3495. Disponível em: <<Go to ISI>://WOS:000245164000020 >.

WATSON, J.; CRICK, F. THE STRUCTURE OF DNA. Cold Spring Harbor Symposia on Quantitative Biology, v. 18, p. 123-131, 1953 1953. ISSN 0091-7451.

WELKER, M.; VON DOHREN, H. Cyanobacterial peptides - Nature's own combinatorial biosynthesis. Fems Microbiology Reviews, v. 30, n. 4, p. 530-563, JUL 2006 2006. ISSN 0168-6445.

YAMAMOTO, J.; TANAKA, $\mathrm{H}$. Dynamic control of the photonic smectic order of membranes. Nature Materials, v. 4, n. 1, p. 75-80, Jan 2005. ISSN 1476-1122. Disponível em: < <Go to $|S|>: / /$ WOS:000226113600020 >.

YAN, X.; ZHU, P.; LI, J. Self-assembly and application of diphenylalanine-based nanostructures. Chem Soc Rev, v. 39, n. 6, p. 1877-90, Jun 2010. ISSN 1460-4744 (Electronic)

0306-0012 (Linking). Disponível em: < http://www.ncbi.nlm.nih.gov/entrez/query.fcgi? $\mathrm{cmd}=$ Retrieve \&db=PubMed\&dopt=Citation \& list uids $=20502791 \quad$ >.Disponível em: < http://pubs.rsc.org/en/content/articlepdf/2010/cs/b915765b $>$.

ZHANG, R.; SUTER, R.; NAGLE, J. THEORY OF THE STRUCTURE FACTOR OF LIPID BILAYERS. Physical Review E, v. 50, n. 6, p. 5047-5060, DEC 1994 1994. ISSN 1063-651X. 